\author{
UNIVERSIDADE DE SÃO PAULO \\ FACULDADE DE FILOSOFIA, LETRAS E CIÊNCIAS HUMANAS \\ DEPARTAMENTO DE LETRAS CLÁSSICAS E VERNÁCULAS \\ PROGRAMA DE PÓS-GRADUAÇÃO EM ESTUDOS \\ COMPARADOS DE LITERATURAS DE LÍNGUA PORTUGUESA
}

\title{
Matrizes para um estudo da literatura feminina: \\ uma leitura comparativa de Sóror Mariana Alcoforado e Sor Juana Inés de la Cruz
}

Betina dos Santos Ruiz

Dissertação apresentada ao Programa de Pós-Graduação em Estudos Comparados de Literaturas de Língua Portuguesa do Departamento de Letras Clássicas e Vernáculas da Faculdade de Filosofia, Letras e Ciências Humanas da Universidade de São Paulo, para a obtenção do título de Doutor em Letras.

Orientador: Prof. Dr. José Horácio de Almeida Nascimento Costa v. 1

São Paulo 2010 


\author{
UNIVERSIDADE DE SÃO PAULO \\ FACULDADE DE FILOSOFIA, LETRAS E CIÊNCIAS HUMANAS \\ DEPARTAMENTO DE LETRAS CLÁSSICAS E VERNÁCULAS \\ PROGRAMA DE PÓS-GRADUAÇÃO EM ESTUDOS \\ COMPARADOS DE LITERATURAS DE LÍNGUA PORTUGUESA
}

BETINA DOS SANTOS RUIZ

Matrizes para um estudo da literatura feminina:

uma leitura comparativa de Sóror Mariana Alcoforado e Sor Juana

Inés de la Cruz

v. 1

São Paulo

2010 


\section{RESUMO}

Esta tese foi organizada e proposta com a finalidade de comparar a obra e a transgressão de Sóror Mariana Alcoforado - ou a ela atribuídas - a parte da obra e à transgressão de Sor Juana Inés de la Cruz, uma vez que são duas personagens exemplares do Barroco ibero-americano. Ambas serão aproximadas a partir do conhecimento dos respectivos modelos de escrita, e também através do conhecimento do trabalho artístico criado com base na herança deixada por elas. Estarão em discussão, ainda, a vida que os conventos femininos de Portugal e NovaEspanha proporcionavam, a profundidade e a insistência com que o século XVII levou a cabo uma política sobre sexualidade e a fortuna crítica de Sóror Mariana e de Sor Juana. Ao remeter o leitor para as Cartas portuguesas, para a Carta atenagórica, para a Respuesta a Sor Filotea, para La carta e para alguns poemas, o

próprio exemplo de trabalho artístico e intelectual feminino estará exposto e fundamentado. A remissão permitirá caracterizar e recuperar a dinâmica do percurso feminino e a sua dicção, dentro de um panorama literário masculino.

\section{PALAVRAS-CHAVE}

Cânone, Literatura feminina, Cartas, Século XVII, Portugal, Nova-Espanha. 


\section{ABSTRACT}

This thesis was organized and projected with the purpose to compare Soror Mariana Alcoforado's compilation and transgression - or the collection to her accredited - to Sor Juana Ines de la Cruz's compilation and transgression, given that they are both exceptional characters of the Iberia-American baroque. Both will be approached by the understanding of their writing model, and also by the perception of their work of art based on the legacy left by them. Moreover on this text will be discussed th style that the female convents of Portugal and New-Spain provided to its nuns profundity and the persistence that the XVII century carried out its political views on sexuality, and the critique treasure left by Soror Marina and Soror Juana. By conducting the reader to the Cartas portuguesas, to the Carta atenagorica, and to the Respuesta a Sor Filotea, to La carta and some other few poems, the example of the artistic creation and the feminine intellect will be exposed and explicated. This guidance will allow the characterization and the restoration of the dynamic of the feminine trajectory, and its voice within a masculine literature scenario.

\section{KEY WORDS}

Canon, Female literature, Letters, Century XVII, Portugal , New-Spain. 


\section{SUMÁRIO}

INTRODUÇÃO 8

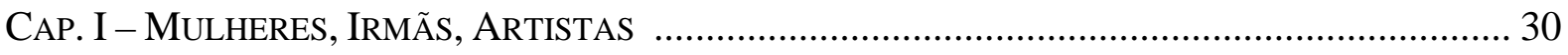

1. As origens e uma tentativa de restituição da memória.................................................... 30

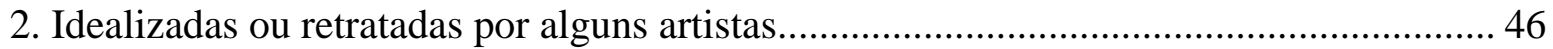

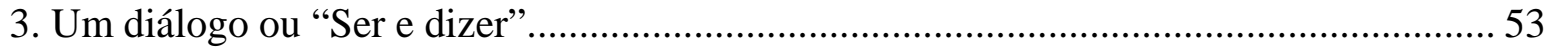

CAP. II - Dois Panoramas DA SeXualidade E Algumas Pistas para A

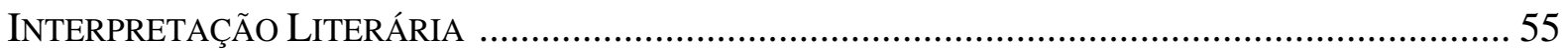

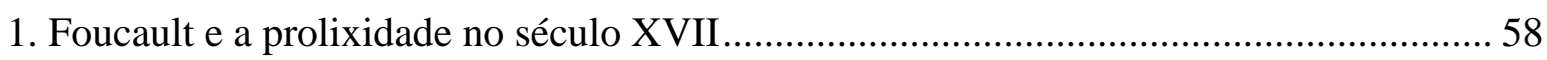

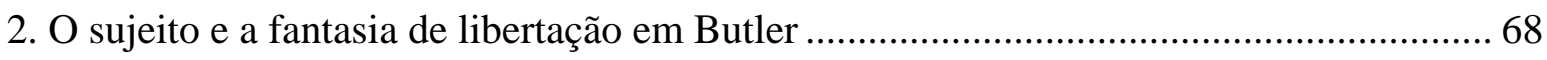

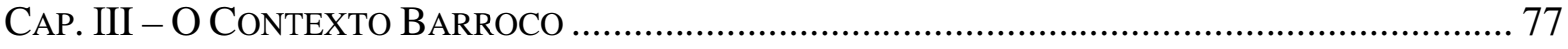

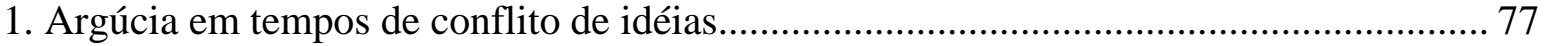

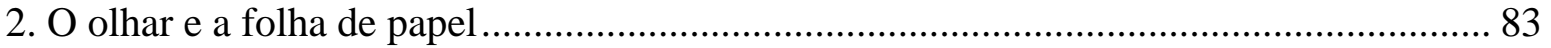

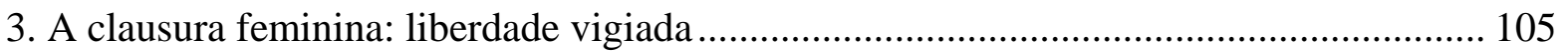

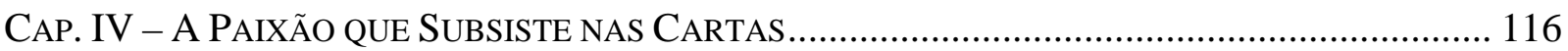

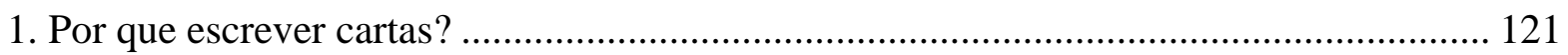

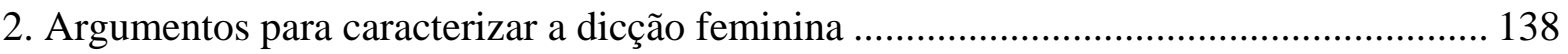

3. As cinco cartas de Sóror Mariana Alcoforado................................................................. 144

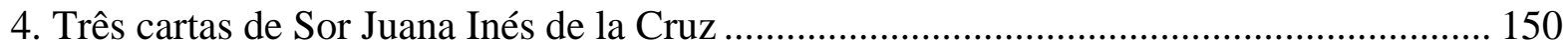

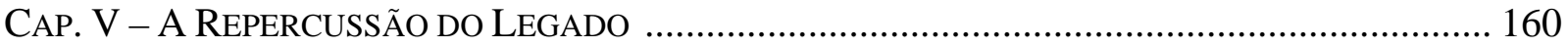

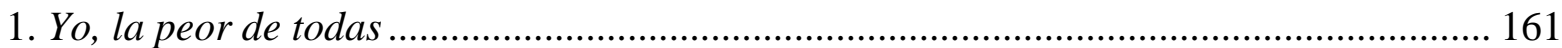

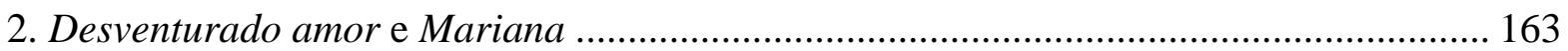

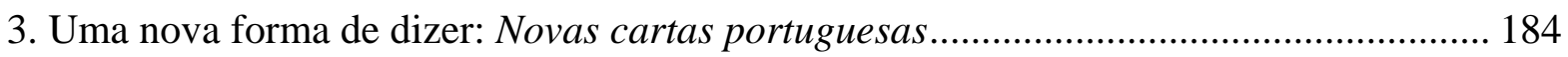

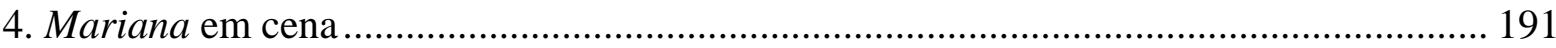

5. O Marquês de Chamilly (Kabale und Liebe) ................................................................. 193

CONCLUSÃO

ANEXOS 


\section{Agradecimentos}

Ao Prof. Dr. José Horácio de Almeida Nascimento Costa, que tão generosamente proporcionou uma entrada tranquila na pós-graduação.

Aos colegas Fermin Vaño Ivorra Filho, José Luciano de Melo e Rogério Caetano de Almeida, com os quais partilhei, durante as aulas de "Formação do cânone das literaturas portuguesa e mexicana modernas”, o encanto pela cultura ibero-americana.

À Prof. ${ }^{a}$ Dr. ${ }^{a}$ Maria Aparecida Santilli (in memorian) e à Prof. ${ }^{a}$ Dr. $^{\text {a }}$ Nádia Battella Gotlib, que propuseram a transformação da minha dissertação de Mestrado em tese de Doutoramento Direto.

À Prof. ${ }^{a}$ Dr. ${ }^{a}$ Myriam Ávila, pela sugestão arrojada de colocar frente a frente, num diálogo imaginário, Mariana Alcoforado e Juana Inés de la Cruz.

À Prof. ${ }^{a}$ Dr. ${ }^{a}$ Teresa Cristófani Barreto, que me introduziu no universo de Camila Henríquez Ureña.

Ao Ronaldo Ventura, do Teatro Curupira, pela simpatia com que mais de uma vez respondeu às minhas dúvidas sobre a montagem da peça Mariana.

À Sra. Maria Teresa Horta, pela gentileza com que me recebeu para falar sobre Mariana Alcoforado e as feministas portuguesas.

Ao António, por me mostrar Beja e por me incentivar durante os últimos anos, com opiniões feitas da sua habitual clareza.

Ao meu pai, Urbano, e à minha mãe, Maria Regina, às minhas irmãs e ao meu irmão, aos meus amigos mais próximos, pela paciência com que me ouviram falar e por vezes tiveram de auxiliar, num trabalho longo como este. 
“(...) quero de mim mesma encontrar em mim a mulher de todas as mulheres”

Clarice Lispector 


\section{INTRODUÇÃO}

Estudar literatura de ficção por meio de manuais escolares, considerando não apenas os textos literários escritos em língua portuguesa e em língua espanhola - embora sejam estes os que mais nos interessam, por nos inserirmos também numa retrospectiva dos estudos literários de Portugal e México -, significa conhecer quase exclusivamente o legado masculino ao mundo letrado, exceto no tocante às produções canônicas e às contemporâneas.

A configuração dos manuais escolares brasileiros, aos quais estamos mais familiarizados, permite-nos destacar, de fato, a presença de Cecília Meireles, Rachel de Queiroz, Clarice Lispector, Lygia Fagundes Telles e Adélia Prado, artistas nascidas no século XX. Clarice, aliás, tem sido referência obrigatória nos livros didáticos utilizados por professores e alunos do ensino médio brasileiro, já que o ingresso em algumas das mais concorridas universidades públicas do país depende, em certa medida, da leitura de $A$ hora da estrela. Além desse plano prático há outro, no qual se situam o trabalho que ela desenvolveu na imprensa brasileira, o cultivo de uma imagem altiva, forjada nas ocasiões em que era fotografada, e o fato de ter morrido precocemente; todos esses fatores concorrem para que Clarice seja digna de referência. O plano mais rico, entretanto, é sem dúvida o estético: se quisermos compreender a presença de Clarice Lispector no cânone brasileiro, teremos de pensar na qualidade dos contos e dos romances que ela assinou e na versatilidade que lhe permitiu, inclusive, recontar para crianças num estilo próprio consagradas lendas brasileiras. 
Por outro lado, verificamos que são muitos os livros didáticos nacionais que omitem outros nomes importantes que dialogavam e, assim, trocavam influências caras ao aparecimento das grandes obras literárias. Teresa Margarida da Silva e Orta, por exemplo, não tem sido incluída entre os autores de língua portuguesa do século XVIII ${ }^{1}$. Sóror Mariana Alcoforado e Sóror Violante do Céu estão ausentes do panorama literário traçado para ensinar sobre a literatura de língua portuguesa do século XVII. Portanto, os alunos brasileiros, mesmo que contemplados com um programa de estudos da literatura brasileira e da portuguesa desde o Trovadorismo português, não recebem notícia de algumas agentes culturais relevantes. A primeira das indicadas é uma das mulheres letradas cujo nome poderia sem dificuldade ser associado ao cenário brasileiro do século XVIII. Teresa Margarida da Silva e Orta tem origem brasileira, nasceu na cidade de São Paulo. Há discordância acerca da autoria de Aventuras de Diófanes, obra publicada em 1752 com o pseudônimo de Dorotea Engrassia Tavareda Dalmira (anagrama de Teresa Margarida da Silva e Orta), mas a própria dúvida poderia ser útil, se a intenção dos compiladores fosse, por hipótese, alertar os alunos para a noção de propriedade intelectual, que só viria a se cristalizar no movimento literário seguinte ao dela, o Romantismo. Sóror Mariana Alcoforado, por sua vez, dá ao leitor um “filtro através do qual se olha a vida”2, dentro do gênero epistolar, que muito esclarece acerca do próprio

\footnotetext{
${ }^{1}$ A tese de Doutoramento de Beatriz Amazonas Cardoso, "Eu sou mulher e não tenho a pena de Homero: Theresa Margarida da Silva e Orta e as origens da escritura feminina portuguesa", orientada pelo Professor Doutor José Horácio de Almeida Nascimento Costa, e apresentada à Faculdade de Filosofia, Letras e Ciências Humanas da Universidade de São Paulo em 2009, procura dar outra visibilidade ao trabalho da escritora que mencionamos, tendo em conta o ambiente cultural masculino em que ela escreveu e a opção, ainda patente, de não incluir seu nome nos cânones da literatura portuguesa.

${ }^{2}$ Quem utilizou a observação que reproduzimos, "filtro através do qual se olha a vida", foi Anna KLOBUCKA, em 2008, para nos alertar para outro texto, Tempo de mulheres, escrito por Isabel Allegro MAGALHÃES em 1987. A autora do livro Tempo de mulheres tentava reequacionar a importância que se dá à autoria masculina das cantigas de amigo, com o argumento de que havia participação feminina nas cantigas: mulheres eram fonte da poesia trovadoresca, eram receptoras da poesia trovadoresca e eram
} 
período histórico em que ela viveu, o século XVII; da mesma forma que Sóror

Violante do Céu compôs muitos sonetos, exemplos de engenhosidade barroca que a ligam a uma corrente de poesia visual muito antiga ${ }^{3}$. Ao que parece, no entanto, as três escritoras foram ignoradas pelos compiladores, o que é mais grave do que terem sido esquecidas. A crítica que poderia ter demonstrado com quantas vozes se cria uma grande obra, abdicou do seu papel.

Considerando que muitas das autoras elencadas nesta introdução como tantas outras que não se enquadram neste recorte geográfico-temporal ${ }^{4}$ dedicaram o seu trabalho intelectual, e mais concretamente a sua escrita, a temas tais como a paixão, as situações limítrofes a que ela conduz, o corpo feminino e a epifania no universo feminino, temas que diversificam e por isso enriquecem a comunicação e a expressão humanas, por que permanecem como exceções dentro daquilo que se reverencia quando se dá a conhecer ao grande público? A escrita feminina constitui um exercício do excesso ${ }^{5}$, o que torna ainda mais difícil aceitar uma recusa ou uma imposição de limites.

\footnotetext{
ainda uma perspectiva plausível naquela poesia. Anna, uma investigadora polonesa dedicada ao ensino da literatura portuguesa na Universidade de Massachusetts Dartmouth - EUA, comentava algumas propostas da crítica literária e de frentes feministas para revisões do cânone. A viabilidade de constituir outras tradições literárias motivou-a nesse texto, intitulado "Sobre a hipótese de uma herstory da literatura portuguesa" (Veredas, $\mathrm{n}^{\circ} 10,2008$, pp. 12-35). Apontando falhas nas propostas e também incentivando o prosseguimento das pesquisas, ela aludiu a Mariana Alcoforado, a respeito de quem já escrevera uma obra.

${ }^{3}$ Ana HATHERLY, em A casa das musas, 1995, situou seus estudos de poesia visual barroca num projeto que buscava reunir dados da participação portuguesa nessa corrente: “(...) O meu desejo foi o de conhecer as suas raízes e o seu trajecto ao longo dos tempos, sim, mas também o de compreender o seu fundamento. Além disso, queria saber o que se passara em Portugal” (p. 10). Ela seguiu esclarecendo que foi preciso consultar "textos soterrados no esquecimento" (p. 10) e, no capítulo "O divertimento proveitoso. Enigmas barrocos portugueses", reprodução de um artigo publicado pela Colóquio/Artes em 1988, aludiu à significativa participação feminina na literatura barroca, chegando até Sóror Violante do Céu.

${ }^{4}$ Walnice Nogueira GALVÃO, no artigo "Mulheres e poetas", D.O. Leitura, no 1, 2005, pp. 23-33, citou Edna St. Vincent Milay, Hilda Hilst e Silvia Plath, além de Adélia Prado e Clarice Lispector, que já mencionamos. Destacou a preferência das poetas modernas por ângulos ousados, quer tratassem do erotismo (ele apareceu em Adélia Prado, por exemplo, numa mescla com o tema da religiosidade), da rebeldia ou da paixão.

${ }^{5}$ Benedito NUNES, O drama da linguagem, 1995. Ao caracterizar a protagonista de Perto do coração selvagem, obra de Clarice Lispector escrita no ano de 1944, Benedito assim procedeu: "Obscuro desejo e força instintiva represada, sede de liberdade e de expressão, a inquietação de que falamos domina a
} 
Acreditamos que exista, como pretendemos caracterizar ao longo de todo este trabalho acadêmico, um interdito que atua no sentido de que a literatura escrita mais conhecida seja a literatura produzida pelos homens. Caso esse interdito seja apenas aludido, em função da sua coercitiva presença no horizonte feminino, talvez expresse mal a falta de visibilidade conferida às mulheres. Propomo-nos a estudá-lo, então, ao lermos as biografias de duas religiosas escritoras do século XVII. À proibição forjada pelos homens estiveram sujeitas as duas autoras comparadas por meio desta pesquisa, intitulada "Matrizes para um estudo da literatura feminina: uma leitura comparativa de Sóror Mariana Alcoforado e Sor Juana Inés de la Cruz”. Ambas enfrentaram o monopólio imposto pelos homens do século XVII e o refutaram em medidas e de maneiras distintas, cada uma no contexto da sua ordem religiosa, de seus projetos (o discursivo, o de vida) e de seu brilho literário.

As Cartas portuguesas, que já fizeram de Sóror Mariana Alcoforado autora escolhida para as leituras obrigatórias no âmbito do sistema educativo português, de 1919 até 1974, hoje ressurgem com Mariana aqui e ali em resgates, digamos assim por enquanto, principalmente por causa da ação de escritoras feministas, como ficará demonstrado no capítulo $\mathrm{V}^{6}$. Sor Juana Inés

personagem: é a sua hybris, sua vocação para o excesso e a desmesura” (p. 20). Assinalava, como se pode ler, o pendor para o excesso, que também estaria na base de outra personagem, G.H., do romance $A$ paixão segundo G.H., de 1964. A ascese desta protagonista é índice da transposição de limites, do rompimento. Já o paratexto de Aparecida Maria NUNES, organizadora de Correio feminino, 2006, ressaltou o cuidado meticuloso de Clarice na preparação de textos de aconselhamento feminino para as páginas de alguns periódicos cariocas. Na segunda carta de Sóror Mariana Alcoforado, de acordo com as duas traduções que utilizaremos, está a palavra “excessos”, selecionada para caracterizar o tipo de delícia ou felicidade que ela dizia ter experimentado ao lado do amante.

${ }^{6}$ É preciso circunscrever melhor a atuação das escritoras feministas: Maria Isabel Barreno, Maria Teresa Horta e Maria Velho da Costa partiram das Cartas portuguesas para uma nova obra, independente, que intitularam Novas cartas portuguesas. A obra, de 1972, estava afiançada pela original nessa incursão feminista. Katherine Vaz, luso-descendente mais interessada em difundir na América do Norte aquilo que entendera como patrimônio português, publicou em 1997 seu romance histórico. Cristina Silva, de cuja obra não nos ocuparemos neste trabalho, publicou Mariana, todas as cartas, no ano 2000, pela editora Gótica. No que diz respeito às traduções, contudo, há um vazio, pois "nenhuma mulher figura entre os 
de la Cruz logrou entrar para o cânone do México no século XIX. Esse feito notável nos liberta da tarefa de quantificar à exaustão a participação dela naquela cultura e deixa-nos muito mais concentrados na transmissão de outra mensagem: por meio do exemplo dela, defendemos que todo percurso feminino merece vida longa, para gerar outras vidas, isto é, a mulher merece criar tradição na literatura. E, de preferência, uma tradição que a própria artista da palavra identifique como profícua.

Se a Sóror Mariana Alcoforado já não é dado que assine uma das páginas da história da literatura portuguesa e se ainda não se lê o caso (de sucesso) de Sor Juana Inés de la Cruz como um baluarte do direito das mulheres à participação na cultura letrada, ainda há o que recapitular e o que propor. Os dois casos são emblemáticos, resguardadas as diferenças, sendo portanto importantes para que valorizemos a literatura feita por mulheres e o próprio exemplo de trabalho intelectual. Nem todas as escritoras serão canônicas, mas cada uma tem seu turno na conversa que se estabelece de autora a autora. Apagar um nome é apagar conexões, e das conexões vêm aquela artista que surpreende e provoca a estranheza essencial ${ }^{7}$.

nomes dos tradutores”, conforme pontuou Maribel PARADINHA (As cartas de Soror Mariana Alcoforado, 2006, p. 34). Para comentar excertos das cinco cartas atribuídas a Sóror Mariana Alcoforado, nesta pesquisa optamos por duas traduções feitas por homens, respectivamente Nuno de Figueiredo e Eugénio de Andrade. A primeira delas à partida terá encontrado público mais amplo, porque fazia parte de um projeto editorial da Europa-América pouco dispendioso (papel de baixa qualidade, gravuras pouco elaboradas, nota crítica pouco isenta, porque muitas vezes apoiada na grandiosidade da mentalidade portuguesa que atravessa a noção de amor em Mariana); a outra, ao contrário, valorizou o aspecto poético do texto em francês. Antes de ambos os tradutores, já Filinto Elísio, Morgado de Mateus, Luciano Cordeiro, Manuel Ribeiro, Afonso Lopes Vieira, Belard da Fonseca e Jaime Cortesão, entre outros, haviam proposto versões do texto das Lettres portugaises. Os resultados foram diversificados, houve textos arcaizantes, houve regionalistas, houve coloquiais. No que diz respeito às mulheres, de todo modo, há que se registrar a postura feminista, a defesa nacionalista recente e uma lacuna em termos de tradução. ${ }^{7}$ Harold BLOOM, em O cânone ocidental, 2001, falou das características que alçam um texto à condição de canônico: "Com a maioria desses vinte e seis escritores, tentei encarar diretamente a grandeza: perguntar o que torna canônicos o autor e as obras. A resposta, na maioria das vezes, provou ser a estranheza, um tipo de originalidade que ou não pode ser assimilada ou nos assimila de tal modo que deixamos de vê-la como estranha” (p. 12). Também apontou o mistério que pode dar ao leitor a sensação de ser um "estranho em casa”(p. 13), quando lê uma obra canônica. Ria LEMAIRE, em "Repensando a 
O legado de Sor Juana Inés de la Cruz foi inspirador para Octavio

Paz. O intelectual mexicano, prêmio Nobel de Literatura de 1990, assumiu a perseguição sofrida por Sor Juana Inés de la Cruz como paradigma para afastar, no caso dele, a possibilidade de abandono da prática artística no contexto mexicano contemporâneo. O olhar que lançou para ela e para o passado mexicano que tencionava recompor, fortalecendo, pode por ora ser assim representado: “la vida y la obra de sor Juana nos restituye a nosotros”»

Como pretendemos demonstrar nesta tese, a mulher, na condição de escritora, pode optar por modelos distintos dos masculinos e, quando optar pelos modelos masculinos, deve fazê-lo com a consciência daquilo que se espera dela. Ser diferente pode resultar em ter respostas similares no êxito; ser igual pode resultar em ser censurada. Transcender a esfera do trabalho muitas vezes codificado como feminino - cada vez mais difícil de definir -, para reinar na esfera do trabalho intelectual que respira independência, implica em conhecimento de si; o narcisismo, nestes casos, será um desdobramento, uma consequência do desejo de alcançar o que o homem já alcançou ${ }^{9}$.

\footnotetext{
história literária”, capítulo de Tendências e impasses, 1994, ofereceu reflexão muito distinta da reflexão de BLOOM. Classificou a história literária como "fenômeno estranho e anacrônico" (p. 58), para poder questionar rótulos: o heroísmo masculino seria mesmo um valor literário? A ancestralidade tem de ser evocada para autorizar a tradição masculina na literatura? Serão sempre "normais” as mulheres, isto é, serão todas sempre iguais, incapazes de brilhantismo e de superação? É interessante que, para fortalecer outro conjunto de valores, ela retrocedeu no tempo, assim: "Nas sociedades medievais, as mulheres foram, progressivamente, sendo excluídas destes centros de cultura erudita” (p. 63).

${ }^{8}$ Octavio PAZ, Sor Juana Inés de la Cruz o las trampas de la fe, 2003, p. 18.

${ }^{9}$ O reconhecimento de uma personalidade narcisista em Sor Juana Inés de la Cruz é objeto de questionamento da parte de Octavio Paz. Motivados pela idéia de que a postura narcisista na assunção de um lugar na literatura de ficção é importante para a mulher, havemos de retomar o argumento algumas vezes e de expor as bases da explanação de Paz, no capítulo I, destinado à biografia de ambas as escritoras e depois mais brevemente, no capítulo III. Vamos também recorrer às palavras de um estudioso de outra grande escritora, Benedito Nunes, uma vez que ele observou na escrita de Clarice Lispector, marco da literatura brasileira, determinação para compor personagens centradas na busca da expressão como forma de aquisição de um conhecimento fundamental dos próprios conflitos internos. As paixões, conforme notou Benedito, fizeram tais personagens mergulharem numa inquietação profunda, que forçava também o motor da liberdade criativa. Por fim, lembramos as palavras de Leda Tenório da MOTTA, no paratexto de Histórias de amor: “(...) Narciso não é um sintoma perverso: ele é nosso espaço
} 
Defendemos que o ato de escrever já significou, sobretudo em casos como o de Sóror Mariana Alcoforado e o de Sor Juana Inés de la Cruz, uma espécie de ativismo avesso à monotonia, podendo ser esta monotonia entendida como a outrora reinante nos conventos femininos. Fiamo-nos sobretudo nas palavras do próprio Octavio Paz: "Lo primero que sorpreende es la monotonía de este regímen" ${ }^{10}$. Consideramos, entretanto, o fato de que a partir da palavra “ativismo”, Margareth de Almeida Gonçalves deu a conhecer as circunstâncias de vida de mais duas religiosas, uma de Goa e outra do Rio de Janeiro, respectivamente no século XVII e no XVIII: "Tiveram ainda em comum a combinação da experiência contemplativa e mística e um ativismo" ${ }^{11}$. Filipa da Trindade e Jacinta de São José, tanto pelo misticismo quanto pelo ativismo, foram estudadas pela referida professora universitária do Rio de Janeiro. Nesta tese surgem como exemplos pontuais do modo de atuação das mulheres desejosas de cultura, de liberdade e de poder para decidir.

A falta de eco face ao empenho feminino e ao inegável contributo que as mulheres deram e dão à cultura letrada é perceptível nos rígidos esquemas dos livros escolares concebidos para a educação formal e tem sido responsável por transformar em vitória mais dura o ganho de cumplicidade entre as mulheres. O sentimento de cumplicidade vem sendo apontado por pesquisadoras como elemento fundamental na sobrevivência da mulher que almeja escrever literatura de ficção. Evocamos nesta introdução, por conseguinte, os conceitos de Virginia Woolf, Sandra M. Gilbert, Susan Gubar e Carmen Alborch, para salientar esse elemento, lembrando que Virginia Woolf já

psíquico. Todos os discursos amorosos são chamados a tratar do narcisismo, a instalar o amor em nosso território próprio, e a só ultrapassar esse próprio num sublime forjado” (p. 19).

${ }^{10}$ Octavio PAZ, Sor Juana Inés de la Cruz o las trampas de la fe, 2003, p. 177.

${ }^{11}$ Margareth de Almeida GONÇALVES, Império da fé, 2005, p. 19. 
afirmou ser imprescindível dinheiro e um teto, para que a mulher possa refletir, escrever e publicar $^{12}$. Ela soube mostrar que a segurança e a saúde física e mental também devem concorrer para o sucesso da mulher nas letras. Porém, tais condições mínimas uma mulher só poderá conquistar depois que transpuser obstáculos muito severos, sobretudo para as mulheres das sociedades fechadas, educadas para servirem aos homens como espelhos refletores da imagem deles em tamanho ampliado. Segundo Woolf, as mulheres da época dela e da anterior estavam despreparadas para administrar os negócios e para assumir a sensualidade feminina, transposta às vezes para a palavra com que elas fabricam um texto. Sublinhamos igualmente a observação que Woolf fez acerca de as mulheres terem muitas vezes preferido o gênero romance ao gênero poesia: tenderam muito tempo à autobiografia, que dispensa a rima, a métrica e os recursos de estilo ${ }^{13}$. Sentem-se mais protegidas da hostilidade (que é muito distinta da indiferença do mundo, oferecida também aos homens como resultado de tentativas de expor um trabalho artístico), ao ousarem menos, ao empreenderem vôos mais tímidos. Perspectivadas assim, essas mulheres talvez nunca tenham sido incompetentes, faltava-lhes confiança para mostrarem o tipo de competência que lhes era direta ou indiretamente cobrada. Trazida à tona, essa competência provavelmente autorizaria a produção feminina. Seria um trunfo para vencer um "padrão difícil de ignorar”14.

Uma leitura do prefácio, da introdução e do primeiro capítulo de The madwoman in the attic, obra escrita por Sandra M. Gilbert e Susan Gubar,

\footnotetext{
${ }^{12}$ Virginia WOOLF, Um quarto que seja seu, 1996.

${ }^{13}$ É interessante ressaltarmos que, ao preparar para uma conferência explicação sobre a necessidade feminina de assegurar dinheiro e um teto, a própria escritora optou pelo gênero romance, centrado numa figura feminina que variava entre Mary Benton, Mary Seton e Mary Carmichael, consoante a vontade do leitor/ouvinte.

${ }^{14}$ Anna KLOBUCKA, “Sobre a hipótese de uma herstory da literatura portuguesa”, Veredas, nº 10, 2008, p. 18.
} 
confirma quão legítimo é defender o sentimento de cumplicidade. Ele é caro ao trabalho intelectual executado pelas mulheres. Descobrimos, por meio da leitura desses textos, que essas duas professoras universitárias criaram uma rotina para a confecção de The madwoman in the attic, rotina na qual primavam pela colaboração, a despeito de individualmente terem visões de mundo muito diferentes. Juntas refletiam sobre o envolvimento das estudantes com o cotidiano de estudos numa instituição de ensino superior (elas lecionavam na Universidade de Indiana, quando surgiu a idéia de escreverem o grosso volume a respeito da literatura feminina do século XIX), sobre a obstinação masculina com a produtividade nos domínios da carreira universitária e, num tom que pode despertar a cumplicidade em suas próprias leitoras, comentavam os prazeres proporcionados pelo sentimento de cumplicidade entre mulheres. O argumento da cumplicidade se apoiou até nos detalhes do livro, como numa carta que a filha mais nova de Sandra M. Gilbert enviara à mãe, para resgatar a memória de uma cena acerca da cumplicidade em Jane Eyre ${ }^{15}$.

Além de aludirem à relevância da cumplicidade na sustentação do trabalho intelectual feminino, as autoras Sandra M. Gilbert e Susan Gubar também chamaram atenção para a existência de uma teoria patriarcal na concepção da literatura. Consoante essa teoria, a mulher é um ser estranho ao meio literário. A insistência com que os homens colocaram as personagens de ficção femininas na condição de volúveis parece ter sido assimilada por uma

\footnotetext{
${ }^{15}$ Charlotte BRONTË, Jane Eyre, s/d, pp. 51-54: "E ardentemente, desejei morrer. Quando, numa prece entrecortada de soluços, pedia o fim, alguém se aproximou. Olhei. Helen Burns estava outra vez perto de mim. À luz moribunda das lareiras, seu vulto avançava pela sala deserta; trazia-me café e pão. (...) Reconhecemos Miss Temple. - Estou à sua procura, Jane Eyre - disse ela. Quero que vá ao meu quarto. E uma vez que Helen Burns está com você, pode vir também. (...) Convidou-nos à mesa, serviu-nos uma taça de chá e uma deliciosa, mas tenuíssima torrada. Depois levantou-se, abriu uma gaveta, e tirando dela um embrulho, revelou aos nossos olhos um ótimo bolo! (...) E então foi uma longa palestra entre ela e Helen, cuja audição constituía realmente um privilégio.”
} 
certa tradição de escritoras, a comprovarem, assim, a dita autoridade masculina. É nesse enquadramento, portanto, que se pode considerar a mulher na literatura como criação masculina, uma vez que a autonomia lhe é negada. Apoiadas nos casos das escritoras Jane Austen, Emily Brontë, Charlotte Brontë, George Eliot e Emily Dickinson, cujas carreiras avançaram do século XIX ao XX, Sandra M. Gilbert e Susan Gubar afirmaram que a mulher se anulava para agradar ao homem e isso quer dizer, em termos concretos, que os textos ficcionais delas continham personagens femininas a assumirem ou a figura do anjo ou a do monstro.

Carmen Alborch, professora espanhola, deu destaque à idéia de cumplicidade logo no subtítulo de seu trabalho, "Rivalidades e cumplicidades” $^{16}$. Assinalou que a relação de mãe e filha tem, ao mesmo tempo, seu quê de amor e de inimizade, reproduzido em todas as outras relações da mulher. Para além dessa ambivalência, retomou a disputa pela formosura entre Afrodite, Hera e Atena, que tiveram Páris como árbitro, e também a diferença entre as personagens bíblicas Lia e Raquel, uma fértil, a outra, estéril, canalizando os dois exemplos para a conclusão em favor da primazia que as próprias mulheres se habituaram a dar aos homens. Ficar à margem, nesse sentido, seria conceder aos homens a liderança.

Investigaremos se algum tipo de recolhimento ou de isolamento pode ter estado na base da atividade criadora de Sóror Mariana Alcoforado ${ }^{17}$. A obra

\footnotetext{
${ }^{16}$ Carmen ALBORCH, Mulheres contra mulheres, 2004.

${ }^{17} \mathrm{O}$ isolamento poderia sinalizar desconhecimento dos benefícios da cumplicidade e do compromisso com a leitura e a escrita; poderia sinalizar também a adoção de um outro tipo de organização para a sobrevivência como intelectual. Sor Juana, como veremos no capítulo I, acabou por optar pelo convento que, como dissemos nesta introdução, era monótono, conveniente para quem preferisse a passividade. De dentro do convento, no entanto, tecia redes de contatos, escolhia protetores, publicava, punha idéias à prova. Não fugiu ao padrão masculino do privilégio à esfera intelectual, uma vez que não escolheu o matrimônio e o núcleo familiar, nem teve uma resposta à altura das dificuldades que se colocavam
} 
atribuída a ela é constituída de apenas cinco cartas em prosa e nenhuma delas é particularmente extensa. Já sabemos que o mesmo acanhamento não pautou o trabalho artístico de Sor Juana Inés de la Cruz, que escreveu e tornou públicos numerosos poemas, sem recorrer à escritura como expressão da autobiografia. Ela optara pela poesia e pelo teatro muito provavelmente em nome do desejo de pertença a um círculo de escritores muito competitivos e dedicado a esses mesmos gêneros, e também deve ter agido assim em nome do amor pela arte e pelo conhecimento, a mesma forma de amor que encantava Virginia Woolf.

Sabemos, todavia, que existem publicações voltadas para o elucidamento da expressão feminina, a exemplo da mesma obra norte-americana The madwoman in the attic que visa a apontar, entre outros elementos, a importância de reconhecermos a origem das máscaras, das deformações criadas pelos homens e de sabermos qual o rótulo perverso dado à insubordinação feminina. Podemos lembrar também, e assim o faremos ao longo do desenvolvimento desta tese, de outros materiais valiosos dedicados à questão da dicção feminina ${ }^{18}$. Contudo, se a essas publicações quisermos recorrer, havemos

perante a transgressão feminina. A via da cumplicidade, que seria um outro padrão de trabalho, Sor Juana entendeu precariamente, na medida em que buscou o diálogo também com homens de poder. Referimos comentário de Mario ROSA, em O homem barroco, 1994, p. 190: “(...) entre as religiosas literatas da época barroca, talvez tenha sabido dar a resposta mais capaz, e certamente mais atormentada, a uma proibição de ordem social, que a impedia, na sua qualidade de mulher e de monja, de satisfazer como os seus homólogos masculinos uma irreprimível ânsia de saber”. Acreditamos que traduz mais ou menos o nosso raciocínio, porque à capacidade somou o tormento e também por ele Sor Juana perdeu privilégios.

18 Apontamos por ora alguns autores, uns mais outros menos conhecidos, uns mais antigos outros mais recentes, uns concentrados em exemplos da língua portuguesa outros em exemplos de língua estrangeira, sem antecipar a apreciação dos postulados que eles formularam e sem equipará-los: João da Silva Correia, Ana Vicente, Álvaro García Meseguer, Robin Lakoff e Roland Barthes. Adiantamos que eles se ocuparam em caracterizar a chamada dicção feminina, tópico de bastante interesse para esta investigação, a ser exposto no capítulo IV. Esclarecemos, contudo, que o texto de Álvaro García Meseguer, apesar de ter merecido comentário bastante positivo da crítica, isto é, de ser leitura recomendada (inclusive por Ana Vicente, pesquisadora cujo trabalho vamos utilizar), não foi encontrado para consulta, o que nos impede de fazer mais do que acusar a descoberta dessa fonte: o título é Lenguage y discriminacion e o ano de publicação, 1988; já constou do acervo da Biblioteca Nacional de Portugal, mas não está mais disponível para consulta; seu autor se dedicava ao campo da Engenharia e, paralelamente, à tradução e às pesquisas linguísticas, as quais deram fundamento para uma teoria do sexismo na língua espanhola; Meseguer chegou a ser abordado por grupos feministas depois de publicar o texto que referimos. 
de empreender uma busca sempre detalhada e adentrar o universo dos discursos feministas, por vezes desvinculados da leitura que os textos literários em suas particularidades estilísticas exigem.

Na indústria cultural, mais precisamente na dramaturgia, logramos encontrar exemplo de atenção à escrita entendida como expressão feminina. No ano de 2005, o grupo de teatro Curupira, fazendo uso do Teatro do Nó, em Santo André, ofereceu ao público uma peça adaptada das Cartas portuguesas. O figurino era expressivo, o que ficou garantido mesmo com a opção pelo minimalismo: faixas foram enroladas ao corpo da atriz e depois semicobertas por um tecido leve, a imitar um sudário. Com a simplificação do vestuário, os idealizadores nos remeteram à idéia do sofrimento de uma mulher doente, febril. O investimento financeiro limitado a que este grupo de teatro esteve preso, visível também na divulgação da temporada (circunscrita aos locais freqüentados por integrantes da comunidade portuguesa em São Paulo), apenas constitui um indício de que podem ser as instâncias marginais, relativamente aos formadores de opinião e do cânone, as vocacionadas para reverenciar a dicção feminina, sem fazer dela um passatempo despretensioso e redutível ao gosto do grande público (e que por isso mobiliza recursos) ${ }^{19}$. Cremos que, na maneira como leu Cartas portuguesas, o grupo de teatro não foi nem redutor nem de idéias pouco elaboradas, não ficando a atenção à produção literária feminina atrelada a esse estigma de escassez ou de improviso.

Lembramos, inclusive, que houve montagens teatrais mais vistosas das mesmas Cartas portuguesas, muito embora a iniciativa que nos move a registrar esta ressalva tenha partido do trabalho de uma artista do sexo feminino

\footnotetext{
${ }^{19}$ Havia notícia do evento no jornal "Mundo Lusíada", distribuído gratuitamente no interior do prédio da Avenida Liberdade, onde está sediada a Casa de Portugal.
} 
reconhecidamente atenta à temática do gênero, o que deve ter feito com que ela pusesse no palco, também, Orlando, de Virginia Woolf, em 1989 e em 2004. Em 1991, enfim, Bia Lessa levou ao Centro Cultural do Banco do Brasil, no Rio de Janeiro, Cartas Portuguesas, tendo no elenco Luciana Braga e Carla Camurati, emolduradas por elementos de plasticidade elogiada:

"Baseado nas cartas amorosas escritas por uma freira no século XVII, o espetáculo de Bia Lessa desdobra a personagem em duas atrizes, Luciana Braga e Carla Camurati,num palco que abriga uma cenografia natural de plantas e águas (...) um ambiente bucólico, com o palco coberto de terra e cortado por um riacho, preenchido de árvores e pedras. A composição concreta de um bosque retrata menos o lugar de uma ação do que a subjetividade da apaixonada. "20

Retornando ao terreno da literatura, tomemos em conta, para que o centro de proposições do presente trabalho seja exposto, o caso da poesia barroca, arte literária do século XVII, redescoberta num contexto relativamente recente, por artistas e pesquisadores de vanguarda, após um longo período de esquecimento, coincidente no mundo hispânico, no português e no brasileiro. Sobre o ensombramento dessa corrente literária no Brasil foi determinante o que escreveu o intelectual Haroldo de Campos, representante de uma vertente paulista atenta aos ditames político-ideológicos da formação da literatura brasileira, aqueles justamente que desprestigiam a escrita feminina por questões de outra natureza que não a estilística, a literária. Defendemos que, guardadas as devidas proporções, da mesma maneira "desobediente" que o professor e poeta de São Paulo prestou homenagem ao trabalho de Antonio Candido e à historiografia da literatura nacional, ao reler Formação da literatura brasileira,

\footnotetext{
${ }^{20} \mathrm{http} / / /$ www.itaucultural.org.br/aplicexternas/enciclopedia_teatro/index.cfm?fuseaction=espetaculos_bio grafia\&cd_verbete=4099, endereço pertencente à Enciclopédia Itaú Cultural de Teatro, foi consultado pela últiam vez em 22 de dezembro de 2009.
} 
havemos de empreender uma apreciação crítica dos textos escritos pelas duas referidas representantes do Barroco $^{21}$. A alegação de Haroldo de Campos era a de que criticar também significa prestigiar e, nesse sentido nós, leitores e pesquisadores de literatura feminina, propomos um estudo retrospectivo em nome do olhar para a herança barroca feminina e da sua valorização.

Ana Hatherly, no paratexto de Lampadário de cristal de Frei Jerónimo Baía, também apontou um desinteresse, neste caso pelos textos barrocos portugueses: "O preconceito contra a literatura barroca, que deriva sobretudo da crítica neo-clássica e que só actualmente começa a dissipar-se, prevaleceu ao longo dos séculos, contribuindo para que toda uma volumosa produção literária, de numerosos e por vezes valiosos autores do século de seiscentos e parte do setecentos, tivesse ficado sujeita ou a um completo esquecimento ou às críticas mais injustamente depreciativas”22.

Sor Juana Inés de la Cruz, poeta da Nova Espanha, mulher entre homens das letras e do púlpito, bem relacionada, protegida até certo ponto, pragmática e ambiciosa, foi apagada do panorama da literatura desde a metade do século XVIII até o fim do XIX. Neste sentido careceu de biógrafos e seus livros aguardaram demasiado até novas edições. Chamada de “A Décima Musa” (expressão dedicada a Safo num momento anterior da literatura), ela muito cedo manifestou interesse pelo conhecimento e pelos livros. A biblioteca que formou no claustro era comentada e invejada. Ainda que restrita ao Convento de Santa

\footnotetext{
${ }^{21}$ Haroldo de CAMPOS, no livro O seqüestro do barroco na formação da literatura brasileira: o caso Gregório de Mattos, 1989, parte de um questionamento para, então, propor a aceitação de uma origem diferente para a literatura brasileira. A própria existência de Gregório de Mattos, poeta barroco brasileiro, havia sido posta em dúvida por muito tempo, em nome de uma perspectiva histórica evolucionista. Haroldo de Campos referia-se sempre ao ensaio de Antonio Candido para refutar o Arcadismo como marco inaugural de nossa literatura e para centralizar o debate na questão do caráter veicular da engajada literatura nacional. O Barroco, voltado para as funções poética e metalingüística, faria o nascimento da literatura no Brasil perder a sua natureza emotiva e referencial.

${ }^{22}$ Ana HATHERLY, Lampadário de cristal de Frei Jerónimo Baía, 1992, p. 14.
} 
Paula, ela formou um grupo de admiradores europeus e americanos, principalmente entre os anos de 1680 e 1690.

No caso de Sor Juana Inés de la Cruz, interessam-nos as características textuais que permitem chamar seus poemas de boa literatura. Tais características interessam-nos bem mais do que as convenções um tanto vazias de sentido e do que a ideologia que concebe um ou outro modelo de literatura ou de escola literária. Se os poemas barrocos prezavam pelo cuidado com a métrica, com o léxico, com as figuras de estilo, com a construção de imagens, com as associações de idéias, com o refinamento estrutural e de conteúdo, enfim, vamonos concentrar em indicar, comentar e reafirmar os procedimentos poéticos de Sor Juana, pois assim estaremos a salientar o domínio que ela exercia e a legitimidade dos escritos e do exemplo que dela ficaram, mesmo que ela tenha concordado em interromper as atividades intelectuais após a censura por um tribunal.

Ainda transitando no percurso ensinado pelos críticos da historiografia da literatura e do Barroco em especial, partiremos de Segismundo Spina e Morris W. Croll ${ }^{23}$, para esclarecer como e por que tencionamos reivindicar para Sóror Mariana Alcoforado destaque no contexto do movimento português e no atual, português ou não. Ao tratarem do estilo barroco na prosa, os autores iluminaram a expressividade e as inquietações da alma, em prejuízo da beleza formal e dos estados de repouso da alma, respectivamente, para explicarem ao estudante com que se preocupavam os prosadores do seiscentos. Sobressai no discurso deles a ênfase dada pelos escritores à energia, como se

\footnotetext{
${ }^{23}$ Segismundo SPINA e Morris W. CROLL, Introdução ao Maneirismo e à Prosa Barroca, 1990.
} 
estivessem a oferecer ao leitor um retrato discursivo da mente em atividade, isto é, do pensamento.

Spina e Croll elencaram pontos da técnica programática da moda anticiceroniana, a fim de mostrarem que mesmo a liberdade e a extravagância notáveis em alguns textos estavam em consonância com o propósito de conferir um determinado estilo à narrativa. A sentença, breve ou longa, bem como o equilíbrio, a escolha das palavras e o uso das figuras eram ponderados pelos escritores do século XVII, no momento do nascimento dos seus textos em prosa. Em cada uma das cartas de Sóror Mariana Alcoforado - umas bastante diferentes das outras, o que pode corroborar a idéia de liberdade, outra idéia expressa por Spina e Croll - havemos de apontar e desconstruir opções ao mesmo tempo barrocas e femininas, para assim pontuarmos a importância da escritora no tocante à produção literária.

Na reconfiguração do quadro das mais expressivas contribuições ao universo literário, vários estudiosos encontraram espaço para as duas escritoras, dois expoentes da escola barroca, Sóror Mariana Alcoforado e Sor Juana Inés de la Cruz. Precisamos situar e discernir entre os estudos mais clarividentes os que nos ajudam a iluminar a questão da paixão e da transgressão, sem deixar de realizar o esforço dos predecessores: analisar biografia, contexto e texto de nossas autoras, tornando visível e única (embora se vá moldando aqui e ali, sempre) a dicção feminina.

Muitos mais são os argumentos, como se verá ao longo desta tese de doutoramento, passíveis de sustentar a importância do estudo dos textos e do exemplo legados por Sóror Mariana Alcoforado e por Sor Juana Inés de la Cruz, nesta busca por uma memória literária mais equilibrada, pois que pautada pela 
contribuição genuína, generosa e fecunda para a história da participação feminina na cultura letrada. Certo é que tencionamos evidenciar, sobretudo, o exemplo de valorização da mulher, em nome de um projeto concentrado num estudo de gênero como este.

Entendemos, por fim, que um estudo universitário em nível de doutoramento deve oferecer como contribuição intelectual para a comunidade uma tese resultante de pesquisa feita nos moldes acadêmicos e que represente oportunidade de reflexão, devidamente fundamentada na bibliografia autorizada, de modo que a tensa estabilidade na qual se sustenta o privilégio masculino de ler, de escrever e de assentir com que outros o possam fazer ceda espaço à capacidade feminina de ler - mesmo sob a pressão de o não fazer -, de escrever - mesmo sob a pena de estar além do propósito de encantar ou de distrair os homens descrentes da profundidade do discurso feminino -, e de assentir, por meio do exemplo e das palavras, com que mais mulheres sintam-se acolhidas nesse universo criativo.

No presente estudo, orientado no sentido de proporcionar acesso a informação organizada sobre a vida, o contexto, a produção textual e a recepção crítica da obra das duas mulheres do Barroco, o português e o hispânico, cabe apresentar, logo no capítulo I, um recorte da biografia de ambas, acrescido de uma tentativa de reconstituição dos modelos discursivos de cada uma. De acordo com essa perspectiva, cumpre propor a leitura de apenas uma parte da obra de Sor Juana Inés de la Cruz, uma vez que a totalidade dessa obra excede enormemente o pequeno número de cartas escritas por Sóror Mariana Alcoforado: são cinqüenta os poemas de amor, sem contarmos os filosóficos, os religiosos, os satíricos e os mitológicos, além da produção teatral, musical e das 
cartas, como a célebre Carta atenagórica; todo esse acervo contra cinco cartas de presumível autoria da religiosa de Beja. O capítulo IV principia com uma tentativa de explicação da disparidade, recorrendo aos números, como se poderá ver.

O capítulo I será construído, primeiramente, em torno da biografia de Sóror Mariana e de Sor Juana. Partiremos de Luciano Cordeiro e de Octavio Paz (também como autor de A dupla chama), passando por Camila Henríquez Ureña, Marie-Cécile Bénassy-Berling e Ortega y Gasset, enquanto discorremos sobre a formação de cada uma delas. À luz de Quintiliano, veremos o orador que arroga o direito de argumentar como vítima, como defendemos ter sido, em parte, a estratégia de Mariana Alcoforado, especialmente na primeira e mais dramática das cartas que ela escreveu. Faremos uma comparação entre um número limitado de imagens de Sóror Mariana Alcoforado e de Sor Juana Inés de la Cruz, já que as duas foram inspiração para muitos artistas, tais como D. Coster, Massard, Craig Del, Matisse, Modigliani, Juan de Miranda e Miguel Cabrera, entre outros. Foram pintadas em tela, foram imortalizadas em esculturas.

Cumpre perspectivar, no capítulo II, o estudo dos textos literários dentro de um referencial de gênero, contando para tanto com as reflexões de dois autores nucleares, os filósofos Michel Foucault e Judith Butler. Ao que eles postularam, iremos intercalando outros estudos, direta ou indiretamente ligados ao caso de Sóror Mariana Alcoforado e de Sor Juana Inés de la Cruz. D. Francisco Manuel de Melo, por exemplo, que voltará a aparecer em capítulos posteriores, será empregue já no capítulo II, bem como Rita Maria de Abreu Maia, que se concentrou na transgressão da freira portuguesa. Para remeter o leitor, ainda que sucintamente, à tese alcoforadista que atentou por vezes para a 
rebeldia de Mariana, buscaremos em vários autores algumas palavras: em ordem cronológica, passaremos pelos portugueses Teófilo Braga, Luciano Cordeiro, Costa e Silva, Godofredo Ferreira, Fidelino de Figueiredo (também chamado para a sustentação de outros pontos deste trabalho), A. Sousa Gomes e Jacinto do Prado Coelho. Pensaremos nos comentários de Sarah Kofman relativamente aos preconceitos de Rousseau e, ainda, na documentação de Diogo Barbosa Machado, que referiu a obra de um misógino português, Baltasar Dias. Isto para além de Margareth de Almeida Gonçalves e Octavio Paz.

Como nos parece mais coerente e completo, procederemos a uma apresentação do Barroco em termos gerais e quanto à literatura do local onde cada uma das escritoras viveu. Utilizaremos no capítulo III referencial teórico de Helmut Hatzfeld, Severo Sarduy, Arnold Hauser e Alfonso Méndez Plancarte, para tratarmos do nome, da génese e das principais características da literatura barroca em que as escritoras estão enquadradas. A Mario Rosa, a Alfredo Saramago e a Isabel Morujão, na tentativa de caracterizar os conventos barrocos. Recorreremos a António Alatorre e a Horácio Costa, quando falarmos da Casa del Placer. A Camila Henríquez Ureña, para concluir um tópico dedicado ao formalismo próprio do Barroco. Além disso, voltaremos a Fidelino de Figueiredo, que já se preocupou em referir os temas de eleição de Mariana Alcoforado; a Ana Hatherly, para contextualizar as críticas feitas à mulher no século XVIII em Portugal, lembrou a erudição praticada no XVII; a Afrânio Coutinho, sobre a necessidade de emulação; a Affonso Ávila, que destacou a participação de Sor Juana em eventos festivos tipicamente barrocos. João Adolfo Hansen nos ajudará a comentar a linguagem barroca, finalmente. A simples enumeração a que acabamos de proceder, no entanto, não pode nem pretende 
esclarecer o peso que foi dado aos fundamentos de cada estudioso. No decorrer do capítulo III, a análise mostrará o entrelaçamento entre os argumentos que nasceram com este trabalho e seus respectivos fundamentos teóricos. E trará, ainda a leitura de oito poemas de Sor Juana.

Para defendermos que as cartas de ambas as escritoras traduzem o modo como desejavam estar no mundo e conhecê-lo - defendendo assim também a atenção às cartas e aos missivistas de outras épocas -, passaremos no capítulo IV por João Adolfo Hansen, mais uma vez; por Ernesto Manuel de Melo e Castro e Renato Mezan, que colaboraram para a obra organizada por Walnice Nogueira Galvão e Nádia Battella Gotlib; por D. Francisco Manuel de Melo e por Edgar Prestage, seu biógrafo; por autores contemporâneos, como Franz Kafka, Walter Benjamin, Fernando Pessoa (e por Leyla Perrone-Moisés, que escreveu sobre ele) e Sigmund Freud; por Michel Foucault, que além de estudar em profundidade a sexualidade, estudou igualmente o papel das cartas na formação do sujeito que procura a sabedoria; por Fr. António das Chagas (e por Isabel Morujão, responsável por uma edição recente e criteriosa da obra desse religioso) e Santa Clara de Assis; por Camila Henríquez Ureña, mais uma vez, que nos ajudará a pensar nas Cartas portuguesas e na Carta atenagórica; por Mário Cesariny e Ana Hatherly, já que se fixaram outrora na questão da honra que autoras portuguesas do século XVIII discutiram em polémicas públicas.

No capítulo V, o último da tese, começaremos a exposição com Maria Luiza Bemberg, cineasta que se dedicou à biografia de Sor Juana; iremos depois para Ruy Chianca, o desconhecido autor de um romance histórico centrado em Mariana Alcoforado, aproveitando considerações de Rilke e de Stendhal (e de Renato Janine Ribeiro, que estudou este escritor), outros dois 
interessados na história em torno de Mariana. Além disso, veremos os verbetes produzidos por Inocêncio Francisco da Silva, Jacinto do Prado Coelho e Álvaro Manuel Machado e recorreremos à autoridade de Castelo Branco Chaves e de Maria de Fátima Marinho, por causa dos romances históricos. Outra autora de um livro pertencente a essa gênero será apresentada e sua obra, Mariana, comentada; trata-se de Katherine Vaz. Terminaremos com Gregório de Matos e Ana Miranda, caros à compreensão do que foram os freiráticos; com Almada Negreiros, irreverente quanto ao interesse romântico português por Mariana Alcoforado; com Maria Isabel Barreno, Maria Teresa Horta e Maria Velho da Costa, que ao contrário se apropriaram criativamente da herança atribuída à freira; com Luciano Cordeiro, o mais dedicado estudioso da vida dessa freira; com Adília Lopes, que fez uma leitura poética irreverente das Cartas portuguesas, que pela linguagem e pelas referências contemporâneas quase fala por si. 


\section{CAP. I - MulHeres, IRMÃs, ARTiSTAS}

“Memória

Uma tinha beleza

E duas ou três tinham charme, Mas charme e beleza eram nada

Porque a erva da montanha Não mantém a sua forma

Onde a lebre esteve deitada"

W. B. Yeats

\section{As origens e uma tentativa de restituição da memória}

À p. 98 da segunda edição de Sóror Mariana, Luciano Cordeiro começava a exposição e o comentário do que havia descoberto em Beja, junto a diferentes tipos de autoridades (militar, acadêmica, religiosa), depois de se ter envolvido emocionalmente e por isso se dedicado à investigação das edições das Cartas portuguesas. Para explicar ao leitor as dificuldades que tivera nessa busca, apontou o descuido para com os documentos históricos e a memória coletiva, até relatar o caso pontual do incêndio deflagrado na cidade, em 1808, por ocasião de invasão francesa. Embora possa parecer desculpabilização da parte de um apaixonado pelas Cartas, a nós parece antes o tipo de relato objetivo que se deseja nesse âmbito, afinal, ele tinha justificativas consistentes (para não sobrevalorizar nem abandonar os resultados da pesquisa): o referido incêndio, segundo Cordeiro relatava, tinha destruído duas das mais diretas fontes de pesquisa, o cartório e os livros de registros das ordens religiosas; por outro lado, o romance de Mariana e de Chamilly representara um escândalo para os Alcoforado, o que muito provavelmente os motivou a não deixar muitos rastros; 
não fosse pelo incêndio, restaria ainda assim muito material para analisar? Talvez não.

Luciano Cordeiro continuou a reconstituição, indicando o local, a data e o nome de batismo de Mariana; falou da filiação, sem fugir às mudanças no nome de família, à genealogia e às posses que podiam indicar o estatuto social. Conseguiu informar sobre as condições de vida dos pais de Marina Alcoforado à altura da Restauração (“situação distincta e influente”, p. 111), incluindo o aspecto intelectual ou formativo. Neste caso fixamos uma observação acerca do pai, Francisco da Costa Alcoforado: "Eleito novamente procurador às cortes, em 28 de outubro de 1645, sendo já 'vereador mais velho, e juiz de fora pela Ordenação', o que denunciava certas habilitações litterarias...” (p. 113). No testamento deste homem, Cordeiro encontrou elementos que permitiam afirmar que o casal Alcoforado: "Promovera zelosamente a instrucção dos filhos, dando-lhes carreiras e collocações distinctas” (p. 115). E também pôde ter acesso ao número de filhos, bem como ao sexo, ao nome e à idade de cada um deles. Eram citados seis filhos, entre eles uma chamada Mariana, já professa naquele ano de 1660, quando estava com vinte de idade ${ }^{24}$. O filho mais velho seria José da Costa; o segundo, Balthazar Vaz Alcoforado, chegaria a ser identificado num dicionário como autor de uma

\footnotetext{
${ }^{24}$ Defendemos que a vocação religiosa de Mariana, ou a falta de vocação religiosa, tem que ser vista pelas ausências e pelas negações, em razão da escassez de documentos. Por exemplo: há um documento em Soror Mariana (p. 233) que mostra que ela teria entrado em disputa com outra religiosa, D. Joana Vellosa de Bulhão, para o cargo de abadessa, em 1709; ele dá conta de que ela perdeu a disputa e, como não se sabe de documento posterior que evidencie intenção de exercer as funções de outro cargo no convento, é justo supormos que pouco movimento pode ter caracterizado a trajetória de Mariana como religiosa. As Cartas portuguesas fazem crer que ela fora porteira, logo em seguida ao amante tê-la abandonado. O que Mariana teria feito até o ano da morte, excetuada a hipótese de sacrifício à vida conventual (que se traduz na opção por cargos, por tarefas e afins)? Se permaneceu sempre com a mesma obrigação individual, não dava mostras de interesse pela rotina, nem de identificação com o perfil de uma religiosa. Seria talhada para esse tipo de vida? Muito provavelmente, não. Isso associado ao perfil que as Cartas portuguesas traçaram, resulta na imagem de uma mulher contrariada, desejosa de contato, cansada da monotonia do claustro.
} 
décima que ganhou alguma fama, também se soube dele como formado em Teologia, doutor, general e, posteriormente, religioso. Teria lutado, conforme outros documentos atestam, na mesma batalha que Chamilly. O ingresso numa ordem religiosa datava de 1669, o mesmo ano da primeira publicação das Cartas portuguesas, e pode ser confirmado por meio de documento transcrito por Cordeiro, em que se fala do dote utilizado na ordenação. Mariana seria a quarta filha, vinda depois de Miguel da Cunha Alcoforado, que como Balthazar pode ser conhecido aqui e ali mediante a leitura de mais alguns papéis. Além de Mariana, ainda haveria outras filhas, Anna Maria, casada quando o pai registrou o testamento, e Catarina, noviça no mesmo convento da Conceição de Beja, da Ordem de Santa Clara. Não constam do testamento os dois filhos menores de cinco anos; a mais nova, Peregrina, entraria aos três anos de idade para o convento onde estava Mariana, por causa do falecimento da mãe, Leonor Mendes $^{25}$. Como ela seria escrivã do convento (provavelmente de 1690 a 1696), Cordeiro procurou e leu notas redigidas por ela; eram notas de falecimento, nas quais ele julgou ter encontrado traços do interesse dela pelas letras e uma certa liberdade auto-concedida, que a fizera abandonar a rigidez no preenchimento daqueles documentos. Cordeiro deu notícia, também, da existência de corretas citações em latim e de letra bastante legível.

Noel Bouton de Chamilly, a quem Mariana Alcoforado se dirigia nas cinco cartas que analisaremos neste trabalho, deve ter chegado a Portugal por volta de 1663, 1664; há indicações de que em 1665 teria recebido uma promoção a capitão e, em 1667, tornar-se-ia marquês. Uma lacuna entre os dados de um documento fizeram Luciano Cordeiro suspeitar que Chamilly

\footnotetext{
${ }^{25}$ A pouca idade de Peregrina Maria é comentada por Luciano Cordeiro, que junta ao material acerca das Cartas portuguesas alguns papéis de outras meninas postas no mesmo convento antes da idade de doze anos.
} 
pretendia partir cedo, mesmo com a guerra em curso. Não havendo mais do que perguntas sem respostas para compor o perfil desse militar francês, alguns outros interessados na história das Lettres portugaises estiveram a investigar o contexto da história de amor e arriscaram, a partir de uns poucos documentos franceses de Saint-Simon, dizer que Chamilly fora intelectualmente limitado, visto que não aprendera a língua portuguesa, por exemplo, além do que tinha pouco interesse pela vida militar e uma compleição forte. Se nada apontava para uma figura sedutora, num período histórico em que a erudição, por exemplo, era um valor estimado, bem como a honra (que podia ser medida pelo empenho físico, quando não o fosse pela argúcia), concentrou-se na personagem Mariana Alcoforado todo o fascínio, já bem descrito por leitores célebres, como Rilke e Stendhal. Ela teria amado, ela teria escrito, ela teria esperado, ela fora exposta à opinião de desconhecidos. Não nos parece, assim, a história de uma paixão vivida a dois, mas de uma paixão profundamente vivida - e recomposta - em solidão. O gesto da repetição que ela praticava ao escrever (fazia muitas súplicas, muitas declarações, muitas análises, em idas e vindas), os leitores imitam quando lêem as Cartas portuguesas, revivem em Mariana, quem sabe pelo gosto em absorverem a forma de erotismo que a mentalidade e os textos barrocos foram capazes de proporcionar. Lembramos aqui que o prazer e a liberdade do amor cortês, permitidos às mulheres, são semelhantes à transgressão amorosa do século XVII; portanto, ao lerem as cinco cartas de Mariana, feita vítima do amor, viva para recordar o amor, os leitores tinham e têm uma possibilidade de enlevo bastante satisfatória. A paixão e o isolamento deram em cartas admiráveis, não terão feito muito, no entanto, para constituir uma tradição, isto é, para diferenciar Mariana, para arranjar-lhe parceiras 
intelectuais, inserindo-a numa rede mais ampla de contribuição intelectual. Nada podemos dizer das intenções dela quanto a essas possibilidades de alçar vôo, já que nem um outro testemunho escrito que mencionasse as Cartas portuguesas num plano pessoal dela foi encontrado. Nem escrito por ela nem por pessoas próximas. Que marca Sóror Mariana imprime em nossa memória? A de uma sensibilidade mal explorada, cujos encantos (que podem ter sido a beleza e o charme de que Yeats fala, nos versos em epígrafe) pereceram junto com a paixão $^{26}$.

Voltando ao plano da biografia, supõe-se que as relações entre Mariana e Chamilly tenham acontecido entre 1666 e 1667 - ano em que ele partiu de volta à França -, e que as cartas tenham sido escritas em 1668, pois em fevereiro desse ano o final da guerra havia chegado e todos os combatentes que desejavam regressar ao seu país de origem deixaram de ter uma missão a cumprir em Portugal. Teófilo Braga imaginou Mariana ainda adolescente a viver o romance com Chamilly, mas desde Luciano Cordeiro tem sido sustentada a hipótese de que o romance ocorrera quando ela já passava dos vinte e cinco anos. Como ela morreria em 1723, sabemos que foi ainda durante sua vida que publicaram muitas das traduções do texto francês. Em Portugal, a primeira tradução só apareceria em 1836, sendo que apenas depois de 1870 o número de traduções cresceria significativamente. A tendência ao crescimento da atenção a Mariana Alcoforado e ao texto das Cartas portuguesas se verifica, também, no interesse do próprio Luciano Cordeiro, que publicou a primeira edição do livro sobre ela no ano de 1888.

\footnotetext{
${ }^{26}$ Claude Barbin, ao lado de Chamilly, pode ter explorado o potencial visto nas cartas da religiosa portuguesa. Essa hipótese, aliás, já foi discutida: pode ser que ele tenha alterado as cartas, tendo o cuidado de promovê-las, de valorizá-las. Apropriar-se de material escrito por uma religiosa residente em local tão distante configuraria crime? Infringiria algum código da época? Ela não era autoridade. E não havia citado nem emulado. Não vinculara o texto a fontes mais antigas que era moda reverenciar.
} 
Nossa principal fonte de conhecimento secundário acerca de Sor Juana Inés de la Cruz, por assim dizer, é a obra Sor Juana Inés de la Cruz o las trampas de la fe, de Octavio Paz. As explicações acerca da família de Sor Juana começam à p. 89 da edição de 2003 e igualmente vêm com o argumento da dificuldade que a pesquisa oferecia. Depois dos comentários para situar o leitor perante outros estudos sobre a vida dela, Paz afirmou que Juana Ramírez de Asbaje, cuja data de nascimento já gerou controvérsia (1648? 1651?), era filha legítima de Pedro Manuel de Asbaje y Vargas Machuca e de Isabel Ramírez de Santillana, dos quais muito pouco se sabe. O que Paz ressaltou em seguida tem relação com a firmeza das mulheres da família de Sor Juana, pois haviam trabalhado muito e com resolução; com a graça e a curiosidade que nela devem ter despontado logo na infância; com as projeções do fantasma do pai, perceptíveis em alguns poemas e nas cartas; e com a iniciação intelectual a partir da biblioteca do avô materno. Pouco pôde expor dos presumíveis dez anos que ela passou na corte, intervalo obscuro entre a vida de criança e o ingresso no convento de São Jerónimo, aos vinte anos de idade. São suposições de Octavio Paz que ela tenha sido mandada para a casa de uns tios em razão do nascimento de seu meio-irmão, ou quem sabe por causa dos custos que a mãe não podia suportar. Ele apresentou ao leitor hipóteses para considerar a solidão em que ela viveu, o desamparo que a caracterizava e a beleza física que a poria em risco de alguma forma. Ficamos a saber que houve quatro anos de permanência sob a proteção dos marqueses de Mancera, recém-chegados ao México para ocuparem o cargo de vice-rei e vice-rainha; Juana era dama desse casal ligado às letras e a boa relação que travaram, para além de ser aludida por Paz, é verificável nos poemas que foram dedicados à marquesa (187-189, "En la muerte de la 
Excelentísima Señora Marquesa de Mancera”). A propósito da sua segunda entrada para um convento, no ano de 1669, Paz rejeita a explicação que envolve um amor infeliz nos anos da corte. Esta negação ajuda a evitar que Sor Juana Inés de la Cruz passe por processo similar ao de Sóror Mariana Alcoforado. A entrada da personalidade portuguesa para o cânone desse país, como mostramos com alguns dados na introdução deste trabalho, passou pela romantização e por um projeto nacionalista de construção da identidade portuguesa. Sor Juana, por seu turno, foi aceita como o maior expoente intelectual do Siglo de Oro mexicano sem sustentação ideológica. O espírito que ela teve na vida pessoal e na artística tem muito mais do Barroco que de um romantismo com que muitas vezes são interpretados e assimilados os casos complexos. Segundo Paz, ela parece ter defendido muito bem a própria honra durante a juventude, o que não exclui a possibilidade de ter participado de jogos eróticos, jogos de iniciação. Sor Juana pode ter aprendido a transitar por esse mundo muito codificado, uma vez que as chances de um casamento - que era, naquela época, alternativa à entrada para o convento - eram remotas e era preciso haver-se com isso, como ela fez. Depois de integrada ao Convento de Santa Paula, da Ordem de São Jerônimo, Sor Juana foi arquivista e contadora, esteve ligada às atividades teatrais e às musicais. Não se pode afirmar que as relações com outros religiosos tenham sido serenas. Antonio Núñez de Miranda, confessor da monja, começou por fortalecer nela a escolha da vida religiosa, depois classificou a erudição e a beleza de Sor Juana como afrontas, ganhou a confiança dela, para então negarlhe apoio num momento delicado. Francisco de Aguiar y Seijas acrescentou às relações de Sor Juana uma dose de tensão: deve ter invejado os dons que se convertiam em obras publicadas, em presentes e em favores e que a levariam a 
pôr uma peça em cena no átrio da catedral em 1693; por isso tudo foi muito austero com ela no episódio da Carta atenagórica. Ao contrário de Sóror Mariana, portanto, ela nunca se alienou no isolamento, esteve antes numa posição privilegiada, onde a atividade intelectual fervilhava, considerando as outras opções com que podia contar em Nova-Espanha. Da paixão pelo conhecimento e da entrega aos jogos sociais, nasceram textos admiráveis e um percurso intelectual bem calculado, mas não nasceu conquista de liberdade verdadeira, pois ela era vigiada. E não se trata de reclamar uma conquista que o século XVII não podia oferecer, trata-se de constatar o hiato entre paixão, ativismo, realização poética, de um lado, e punição, do outro. Que marca Sor Juana imprime em nossa memória? De entrega à vida intelectual e de desenvoltura até certo ponto. Como se verá por meio de algumas imagens, essa desenvoltura passava pelo aspecto físico que Yeats - mais uma vez lembrado por causa da epígrafe do presente capítulo - censurava.

Pensemos agora nos modelos de formação cultural e espiritual do século XVII. Isabel Morujão vem alertando para o fato de que os modelos portugueses estão, na atualidade, em fase de estudo. Mesma apreensão da situação de estudo foi enunciada por outra investigadora portuguesa, Maria de Lurdes Correia Fernandes ${ }^{27}$. Todavia, mesmo com alguns dados já levantados, esses modelos de formação, por enquanto, são muito difíceis de recompor,

\footnotetext{
${ }^{27}$ O que Maria de Lurdes Correia FERNANDES escreveu no artigo "Recordar os 'santos-vivos': leituras e práticas devotas nas primeiras décadas do século XVII português”, da revista Via Spiritus, n ${ }^{1}$ 1, 1994, pp. 133-155, é complementar ao que Isabel Morujão postularia em "Livros e leituras na clausura feminina de setecentos", Revista Línguas e Literaturas, Porto, $\mathrm{n}^{\circ}$ XIX, 2002, p. 134: "O complexo estudo das leituras - que implica, naturalmente, saber (tentar saber) não só quem lia e o que se lia (ou se se lia), mas também o como, o quando e o porque se lia - das obras ou textos de espiritualidade (desde livros de oração, guias espirituais, catecismos... até as obras hagiográficas) na Época Moderna apresenta-se ainda como um terreno imenso a desbravar, especialmente se integrado ou articulado tanto com outras dimensões da partilha do espírito quanto como com diferentes formas do viver religioso e social que as enformam...”.
} 
porque entre as fontes documentais utilizadas nessa recomposição (catálogos das livrarias dos conventos, manuais dos confessores para as freiras, conselhos esparsos registrados em cartas), poucos foram os catálogos encontrados. Sendo eles muito diversos uns dos outros, tornam as conclusões controversas e frágeis, no sentido de que muito ainda terá que ser questionado daqui para a frente. As ordens religiosas em Portugal ou não entendiam a documentação das leituras como uma tarefa importante ou cumpriram com disciplina essa tarefa, até porque as exigências do clero apontavam para isso, mas os registros não resistiram à passagem do tempo, como aconteceu e acontece, ainda, com muitos tipos de documentos.

Ao todo são dezesseis os catálogos de que se tem notícia, variáveis em muitos aspectos, como na quantidade de livros que possuem, no rigor do apontamento desses livros, na data e na ordem religiosa a que se referem ${ }^{28}$. Tais catálogos já permitiram descobrir, por exemplo, que durante o século XVII chegavam aos conventos femininos livros portugueses, espanhóis, italianos e franceses, além de livros escritos em outros idiomas. No contexto desta pesquisa de doutoramento, centrada também numa obra cujo texto original está em francês, interessa saber que pelo menos 3\% dos livros presentes nos catálogos eram franceses, pois isso significa que as religiosas podiam ter conhecimentos linguísticos suficientes para ler nesse idioma ${ }^{29}$. Não foi descoberto catálogo

\footnotetext{
28 Isabel MORUJÃO, “Livros e leituras na clausura feminina de setecentos”, Revista Línguas e Literaturas, Porto, ${ }^{\circ}$ XIX, 2002, p. 118: “A principal fonte documental deste trabalho foi um conjunto de catálogos de livrarias de conventos femininos, disponíveis no Arquivo Nacional da Torre do Tombo, relativos ao cumprimento do edital régio de 10 de Julho de 1769, pelo qual a Real Mesa Censória solicitou a todo o país a inventariação das bibliotecas privadas.”

${ }^{29}$ Por ser informação diferente, que só encontramos em uma fonte, somamos à reflexão acerca da possibilidade de Mariana Alcoforado ter domínio ou, pelo menos, algum conhecimento do idioma francês, o argumento apontado por A. Sousa GOMES, em Madre Mariana Alcoforado, sua graça e seu amor, 1964: "Havia uma companheira de Mariana designada por Madre Maria Leonor de S. Luis. Talvez fosse esta a Pedegache. Francesa, podia ser que exercesse a profissão de professora do seu idioma, e se tivesse prestado a traduzir as Cartas que Mariana dirigia ao seu amor. Deve ser esta a razão de aparecer
} 
relativo ao Convento da Conceição de Beja ${ }^{30}$, onde Mariana Alcoforado viveu, mas como não se sabe ao certo quanto dos dados são comunicáveis, quer dizer, o que eles dizem da generalidade dos programas dos conventos portugueses, a suposição de que Mariana Alcoforado pudesse compreender o idioma francês (para que tivesse redigido cinco cartas nesse idioma) fica aqui posta. Com igual propósito damos a conhecer a existência de gramáticas do idioma francês entre os livros das freiras ${ }^{31}$ - que, apesar de tudo, não sabemos se eram livros partilhados ou não. Pode ser, no mínimo, indício de curiosidade intelectual por parte delas, como o são igualmente as anotações manuscritas que dão conta da passagem dos livros de uma religiosa para outra. Talvez elas os partilhassem, no momento em que mais uma passava a ser considerada apta para determinada leitura. As religiosas aceitavam diretrizes para o desenrolar dos seus estudos e, conforme se sabe hoje, entre as diretrizes estava a escolha do melhor momento para ter contato com um livro. Os livros eram doutrinários e se inseriam numa linha doutrinária maior, a dos diretores espirituais. A direção espiritual seria maior do que a cumplicidade, afinal? Parece, de fato, que mais eficaz a longo prazo era o controle exercido pelos homens da Igreja do que a colaboração de mulher a mulher na Igreja. Mas ainda assim ela existia e havemos de sublinhála, pois deve ter dado ânimo a muitas religiosas escritoras.

como a epistológrafa” (p. 9). Madame Pedegache, ainda segundo A. Sousa Gomes, teria aparecido num catálogo de 1808 como a autora de Lettres portugaises.

${ }^{30}$ Reforçamos neste ponto a observação de Luciano Cordeiro, expressa na obra Soror Mariana, 1890, de que os livros relativos às ordens religiosas de Beja foram queimados no incêndio provocado por tropas francesas no cartório da cidade. À p. 99, ele conta que havia "vestígios" da história do convento, mas eles se encontravam "dispersos".

31 Isabel MORUJÃO, "Livros e leituras na clausura feminina de setecentos", Revista Línguas e Literaturas, Porto, nº XIX, 2002, p. 161. 
Em atenção a um passo recomendado e referido por Isabel Morujão, consultamos as cartas de um desses diretores, Fr. António das Chagas ${ }^{32}$. Na sua Carta V, escrita para a “Muito Reverenda Madre Soror N. e Senhora Minha”, ele inseriu, entre os comentários acerca da rotina de estudioso e pregador, a menção a uma obra que convém salientarmos. Quando informou sobre as leituras que já havia feito, convencendo a interlocutora a imitá-lo, evidentemente, falava das Cartas de Santa Teresa ${ }^{33}$, na edição de Palafox. Dom Juan de Palafox e Mendoza, que de fato editara tais cartas em 1658, tinha, como podemos atestar pelo exemplo de Fr. António das Chagas, nome destacado em Portugal; e como fora bispo de Puebla antes de Manuel Fernández de Santa Cruz (o homem que atraiçoou Sor Juana no caso da Carta atenagórica), arcebispo do México e até vice-rei, era certamente uma referência para Sor Juana também. Asunción Lavrin, no capítulo "La religiosa real y la inventada: diálogo entre dos modelos discursivos"34, aponta Palafox como o autor de outro texto importante, "Pastoral a las madres abadessas y religiosas de los monasterios de Santa Catalina, La Concepción, San Jerónimo, Santa Teresa, Santa Clara, la Trinidad y Santa Inés, de la cuidad de los Angeles, cuan indigno obispo de la misma ciudad”. Lavrin mostra, ao escolhê-lo, que ele era referência, direta ou indireta, na prática religiosa de Sor Juana. Poderá ter sido de alguma forma o regulador da rotina de

\footnotetext{
${ }^{32}$ Fr. António das CHAGAS, Cartas espirituais, 2000. A leitura das cartas mostrou, além do que procurávamos, que Fr. António das Chagas esteve em Beja por mais de uma ocasião: em 1673 por duas vezes; em 1676, uma vez; e em mais duas ocasiões que não podemos indicar com precisão, porque as datas estão indicadas de maneira incompleta (p. 455 e p. 495).

${ }^{33}$ A propósito de Santa Teresa, externamos pelo menos a dúvida: teria estado entre as leituras de Sóror Mariana Alcoforado? Camila Henríquez UREÑA (Obras y apuntes, 2006, p. 158) já as aproximou consoante um tema que abordaram: "En Santa Teresa la pasión fue divina. En un convento de Beja, en Portugal vivió en el siglo XVII otra mujer cuyo epistolario privado ha merecido fama al publicarse. En esta mujer la pasión fue humana. Descendamos hasta el amor mundano para hablar de Mariana Alcoforado.” Henríquez Ureña continuou a comparação: “Así como Santa Teresa sentía compasión por el diablo porque no ama, Mariana siente compasión por el Marqués, porque es incapaz de corresponder a una gran pasión” (p. 166).

${ }^{34}$ Monika BOSSE, Barbara POTTHAST e André STOLL, La creatividad femenina en el mundo barroco hispánico, 1999, pp. 535-558.
} 
Sóror Mariana Alcoforado? É a escassez de dados que não permite essa extrapolação, mas que ainda assim não a invalida.

Voltando às cartas, vejamos que na $\mathrm{X}$, endereçada a uma "Madre Abadessa”, Fr. António das Chagas referiu a leitura de Combate espiritual, que Isabel Morujão identificou como o livro de Teatino Lourenço Scupoli, autor falecido naquele mesmo século. Na XVII, ele se dirigiu à "Madre Soror F. e Senhora minha”, fazendo rápidas sugestões de leitura: aconselhou que ela procurasse o que o Padre Puente ${ }^{35}$ escrevera, bem como informações a respeito das vidas de santos. O autor nomeado, Luís de la Puente, tivera obra editada em Portugal em dois anos, 1649 e 1650. O livro desse espanhol voltaria a ser indicado na Carta XX, que tem também outra indicação, esta para Infância de Cristo, escrita pelo Padre Bartolomeu do Quental. Devemos ter em consideração o fato de que, então, era mais uma obra atual (publicada em 1666 em Lisboa). É uma pista para que pensemos nas atividades formativas das religiosas portuguesas: elas estariam atualizadas? Eram mais independentes, intelectualmente, do que se pode supor no século XXI?

Já na Carta XXVIII, Fr. António das Chagas não utilizou qualquer expressão que nos ajude a descobrir a destinatária, mas continuou a manter diálogo acerca de textos, mencionando o nome de Eusébio, apontado em nota de rodapé da p. 122 como João Eusébio de Nieremberg. Na Carta XLII, Fr. António das Chagas comentou mais um autor, S. João Clímaco, provavelmente na tradução do Fr. Luís de Granada. Na XLVIII, remeteu o destinatário a S.

\footnotetext{
${ }^{35}$ Um livro desse mesmo autor aparece como pano de fundo das pinturas de Miranda e de Cabrera, indiciando uma possível leitura de Sor Juana - ao menos outro autor presente como pano de fundo nas pinturas, Kircher, foi realmente lido por ela. Ressaltamos, assim, a correspondência: Luis de la Puente pode ter sido objeto de estudo de Sóror Mariana Alcoforado e de Sor Juana Inés de la Cruz. A dúvida que ainda resta se prende ao fato de que esse autor não é lido na atualidade, o que torna difícil avaliarmos que tipo de influência ele teria legado às religiosas em questão.
} 
Francisco de Sales, responsável pela escrita de Tratado do amor de Deus. Na LXXVIII, está Louis de Blois ou Ludovico Blosius, autor de várias obras. Na LXXX, temos notícia de Fr. Alonso de Andrade, o autor de Meditaciones diárias de los mysterios de N. S. Fe y de la vida de Christo N. S. y de los santos. Na Carta LXXXVI, Fr. António das Chagas chamou atenção para Alonso Rodriguez, o autor de Ejercicio de perfección y virtudes cristianas.

A seguir à página de rosto da segunda parte das Cartas espirituais, edição publicada em Lisboa no ano de 1687, Fr. António das Chagas usou versos de Horácio, demonstrando com a escolha que tivera formação mais ampla do que a $\operatorname{devota}^{36}$. Se ele teve, poderiam as religiosas terem tido o mesmo? Sóror Mariana pode ter lido poesia clássica? ${ }^{37}$ Pensando que ambos estiveram fora da clausura um dia, sim, podem ter lido obras consagradas, como as da poesia clássica. Sóror Mariana, uma filha da nobreza, pode ter estado naqueles círculos que Maria de Lurdes Correia Fernandes apresenta, dentro dos quais era prática usual receber dedicatórias. A lista preparada por ela é longa e mostra quantas e quais senhoras ilustradas haviam merecido palavras especiais nas obras de direção espiritual do século XVII. Por receberem, pode ser que as lessem habitualmente, que as seguissem. Apoiadas nesta possibilidade cogitamos a possibilidade de Mariana Alcoforado ter conhecido a vida de alguns

\footnotetext{
${ }^{36}$ Fr. António das CHAGAS, na Carta CXXV, que a edição de 2000 de Cartas espirituais traz à p. 270, usou expressões e um jogo de palavaras que nos remetem à novela de cavalaria Palmeirim de Inglaterra: "O encantamento das noviças dura, a meu ver, porque há mais palmeirins que amadices". Citando poesia e revelando domínio de outro gênero literário, Fr. António acusava uma cultura literária que outros religiosos talvez tivessem.

${ }^{37}$ Houve religiosas portuguesas que, como se sabe, tomaram parte em grupos para escrever e trocar poesia mundana. Em 1695, em Lisboa, circulou o texto de Sor Juana Inés de la Cruz chamado Enigmas ofrecidos a la Casa del Placer, casa esta que congregava freiras portuguesas interessadas em poesia. Desse intercâmbio inferimos que também as religiosas em Nova Espanha se deram essa liberdade expressiva. Sai reforçada, assim, a idéia de que no âmbito dos conventos do século XVII era possível ler, escrever e compartilhar literatura de ficção. Deixa de ser, portanto, tão inusitado que Sóror Mariana Alcoforado o fizesse, mesmo que ela não tenha assinado o texto, mesmo que não conheçamos mais outro texto atribuído a ela. Mesmo que faltem informações sobre as atividades das religiosas do convento em que ela esteve enclausurada.
} 
santos e ter pensado num modelo de conduta centrado na expiação da culpa. Ela se mortificava, ao escrever, quase que agradecendo pelo infortúnio, já que ele trouxera a ela lucidez, sabedoria.

Procurando agora resumir os dados extraídos das Cartas espirituais de Fr. António das Chagas, para podermos passar mais especificamente à formação de Sor Juana Inés de la Cruz, pontuemos apenas que Fr. António das Chagas mencionou, além dos nomes que transcrevemos, Nicolau Ésquio (muitas vezes: por exemplo à p. 324, à p. 405, à p. 424, à p. 448, à p. 467 e à p. 496), Santa Teresa (à p. 325, à 343, à 398, à 414, à 460 e à 495), Santo Inácio de Loyola (à p. 420) e Soror Maria de Jesus de Ágreda (à p. 459).

Antes de passarmos à formação de Sor Juana Inés de la Cruz, lembremos ainda de Marco Fábio Quintiliano, orador, professor de Oratória e de Gramática do século I ${ }^{38}$. Sua obra, De institutione oratoria, é composta de doze livros, segundo o que foi descoberto em 1417. Logo no princípio desse longo texto, Quintiliano definiu a Retórica em termos ideais, propondo passo a passo uma espécie de revisão das definições anteriores à dele, como a de Isócrates, a de Platão, a de Cícero e a de Aristóteles. Ao examinar as palavras dessas e de outras autoridades, ele pretendia refutar enquadramentos dos quais discordava; pretendia afirmar a Eloquência como prática discursiva que cabia ao homem virtuoso, o que queria dizer que só esse homem poderia ser chamado orador. Nessa controvérsia, estava implícita a questão da persuasão: seria a única finalidade de um orador? Para Quintiliano, não; a Eloquência era a Ciência do falar bem, portanto falar bem era o objetivo do orador virtuoso, a persuasão seria objetivo acessório, secundário. Falar bem, no entanto, exigia o exercício

\footnotetext{
${ }^{38}$ Na Respuesta a Sor Filotea, Sor Juana demonstra ter lido Quintiliano e ter estudado Retórica a partir de outros autores também.
} 
retórico. Se quisermos entender o processo de criação dos artistas seiscentistas, para os quais a emulação, por exemplo, era importante, chegaremos a outra noção cara a Quintiliano e ligada ao exercício retórico: a noção de talento natural. Quintiliano rechaçou a idéia de talento natural, como havia rechaçado a de persuasão: “(...) ninguém certamente pode ser orador sem ter estudado” (p. 50). E chegamos, então, a Mariana Alcoforado.

Se de fato escreveu as Cartas portuguesas, a religiosa tinha um modelo discursivo, extraído de leituras. Talvez tenha acedido, então, ao "repertório de grandes gestos, rituais e fórmulas criados pela sociedade, que o sentimento tem à sua disposição e se vê obrigado a usar, como se de um equipamento se tratasse” ${ }^{39}$. O amor, de acordo com Ortega y Gasset, leva a desejar mais vida, ele instiga, projeta o amante para fora de si: “A curiosidade predispõe o olhar, mas a visão tem de ser perspicaz” (p. 156). E fora de si, Mariana Alcoforado, uma religiosa com alguma educação formal, pode ter recorrido à figura miserável para advogar sua causa, da mesma forma como outros homens já haviam procedido na Antiguidade e mereceram por isso a desaprovação de Quintiliano. Não se trata, portanto, de sonhar para ela um talento natural que não podemos documentar, nem de simplesmente vê-la como fruto de um período histórico de uma poética muito codificada e vigorosa, sem indicar algumas hipóteses de formação. Sóror Mariana pode, ao que parece, ter lançado mão da instrução que teve, associando a isso o apego barroco aos sentidos e a força do próprio sentimento amoroso. Teria privilegiado o olhar, como notaremos no capítulo III, além de ter tomado uma opção pela figura miserável, aquela que persuade porque comove. Ao contrário de Santa Teresa,

\footnotetext{
39 José ORTEGA Y GASSET, Estudos sobre o amor, 2002, p. 147.
} 
que encontrara no desarreigamento da alma o canal para o enlevo, Mariana investiria na relação com o outro, na apreciação, no prazer e na repetição. Em outras palavras: Santa Teresa ensinara que o enlevo vinha do estar absorvida; Mariana relatava o ser absorvida.

Ela não persuadiu o amante. Contudo, galgou outro terreno. Deleitou os leitores e soube mais de si. "Bem vejo que te amo como uma louca"40, ela escreveria, despontando aos olhos do antigo amante como uma figura miserável. Por fazer de si mesma uma mulher vitimada - mas que desejava -, Mariana ganhou leitores e os moveu num campo para o qual há sempre demanda: o do discurso sobre o amor ${ }^{41}$. Sob o prisma de muitos de seus sucessores portugueses, as mulheres portuguesas saíam dessa obra transformadas (em amantes devotadas? Em mulheres intensas que sabem se entregar ao homem?). A ideologia ou o gosto por trás da operação não nos compete discutir neste momento; compete apontar um procedimento, um espírito e um ganho que foram tomados de Mariana Alcoforado.

Sor Juana, por seu turno, era leitora de Atanasio Kircher (16021680), segundo Marie-Cécile Bénassy-Berling afirma à p. 630 de La creatividad femenina en el mundo barroco hispânico; em El sueño, encontraremos evidências da leitura de Ars magna lucis et umbrae, como se poderá ver no capítulo III deste trabalho. O jesuíta alemão Atanasio Kircher, de acordo com o que apuramos, foi lido em Portugal e serviu para ilustrar o raciocínio de um texto de 1761, Espelho critico, no qual claramente se vem alguns defeitos das Mulheres, o que não anula a possibilidade de ter sido conhecido antes, já que a

\footnotetext{
${ }^{40}$ Mariana ALCOFORADO, Cartas portuguesas, 1974, p. 63.

${ }^{41}$ Octavio PAZ, A dupla chama, 1994, p. 93: "Se fizermos uma retrospectiva da literatura ocidental durante os oito séculos que nos separam do 'amor cortês', logo comprovaremos que a imensa maioria desses poemas, peças de teatro e romances têm o amor como tema”.
} 
inserção do nome dele num texto do século XVIII vinha a propósito de uma querela pública semelhante a tantas outras daquela época. Embora os autores portugueses envolvidos nas querelas que circulavam em papéis volantes quisessem claramente demonstrar erudição, ficavam muitas vezes pela autoridade dos antigos (Pitágoras, Temístocles, Aristipo, Crisipo etc), pelas citações em latim e pelas novidades muito difundidas, esse era o repertório partilhado por nobres ilustrados e religiosos. O texto no qual encontramos essa referência ao jesuíta traz outra grafia para o nome, "Kirker”, mas como cita o Nepal (grafado como “Necal”), abordado por Kircher em mapas e em livros, acreditamos que se trate desse autor; foi publicado anonimamente com o pseudônimo de “Irmão Amador do Desengano” e se enquadrava numa polêmica específica que voltaremos a aludir em nota de rodapé do capítulo IV, por ocasião da discussão da defesa da honra feminina.

Quanto Sor Juana saberia das suas limitações formativas? MarieCécile Bénassy-Berling se perguntou qual o grau de lucidez em Sor Juana, porque a própria leitura de Kircher a colocava num universo algo ultrapassado. O que ele divulgou como ciência nunca chegaria a ter aplicação prática, por exemplo. Se era lúcida para saber que tinha muito a estudar e que valia a pena o esforço (de entrar nos jogos sociais, render homenagens aos poderosos, contrariar os superiores hierárquicos, criar uma biblioteca, manter correspondência com religiosas de outras ordens, em outros países etc), será que a dúvida quanto ao teor das leituras teria escapado a Sor Juana? Pode ser que não tenha escapado a dúvida ou o lamento, não da mesma forma efetiva como escaparam as obras da literatura francesa e da inglesa e as noções da filosofia e da ciência da época dela. 


\section{Idealizadas ou retratadas por alguns artistas}

O que o leitor de hoje admira em Sóror Mariana Alcoforado? O que celebra em Sor Juana Inés de la Cruz? Se vem sendo treinado para observar uma e outra com determinados métodos, isto é, com um dado arcabouço teórico, pode ser que tenha recebido a influência de alguns pintores, porque Sóror Mariana Alcoforado e Sor Juana Inés de la Cruz foram retratadas em variadas épocas. Luciano Cordeiro e Octavio Paz tiveram o cuidado de reproduzir imagens de algumas dessas obras e também de comentá-las sucintamente ${ }^{42}$. De fora do levantamento de Cordeiro, ficaram, por motivos óbvios ligados à diacronia do culto a Mariana: os desenhos de Matisse e de Modigliani, bem como pinturas de Jorge Colaço e de Jorge Barradas, cujo painel entrou na Exposição do Mundo Português, entre as "Mulheres Ilustres de Portugal” ${ }^{43}$. Houve já intelectuais que endossaram o trabalho dos pintores dedicados a Sóror Mariana e a Sor Juana, concorrendo, assim, para cristalizar uma imagem (visual e mental) delas. Vejamos o exemplo de Gabriela Mistral, aliás citada por outra intelectual, Camila Henríquez Ureña:

\footnotetext{
${ }^{42}$ Luciano CORDEIRO, Soror Mariana, 1890, tem no intervalo das páginas 348 e 349 uma lista que informa sobre: 1) gravura em cobre, feita por Harrweyn em 1697, para uma edição de Haya; 2) gravura em cobre, feita por D. Coster em 1716, para uma edição desse ano e outra de 1742, ambas de Haya; 3) gravura em cobre, feita por Eisen e Marillier e gravada por Massard e Ghendt em 1771, para uma edição desse ano e outra de 1780, ambas de Haya; 4) gravura em cobre, feita por Craig e Mackenzie em 1808, para uma edição desse ano, outra de 1817 e uma última de 1828, todas de Londres; 5) gravura em cobre, sem indicação de autor, do ano de 1838, em edição de Aillaud; 6) quadro a óleo, feito por Emilia Santos, e inconcluso até a data da $2^{\mathrm{a}}$ edição revista de Soror Mariana. Octavio PAZ, Sor Juana Inés de la Cruz o las trampas de la fe, 2003, inventariou: 1) óleo anônimo; 2) retrato feito por Juan de Miranda; 3) retrato feito por Miguel Cabrera em 1750. À p. 174, Paz esclarece que o mais antigo dos três retratos é o de Juan de Miranda, a partir do qual Cabrera fez o seu trabalho; diz também que a palavra "retrato", no caso de Miranda, deve sugerir que Sor Juana realmente serviu de modelo para o pintor, ao passo que no caso de Cabrera, quer dizer o mesmo que "cópia". A data do primeiro, incerta, Paz situa entre os anos de 1680 e 1688, por causa da flexibilidade das monjas e também por causa da proteção da condessa de Paredes. Maior importância, contudo, ele deu às obras postas pelos pintores pôs na estante atrás de Sor Juana; identificou algumas para poder comentar as leituras de Sor Juana.

${ }^{43}$ Maribel PARADINHA, As cartas de Soror Mariana Alcoforado, 2006, p. 126. Também Anna KLOBUCKA, Mariana Alcoforado, 2006, refere a obra, à p. 122, salientando o estilo modernista do painel, que destoava da maior parte das obras restantes, feitas no estilo acadêmico de então.
} 
“'La luz de la meseta, le hizo aquellos sus grandes ojos rasgados para recoger el ancho ancho horizonte. Y para ir en la atmosfera sutil, le fue dada esa esbeltez suya, que, al caminar, era como una reverberación fina de luz, solamente,",44

Parece que Mistral assumia a postura de Sor Juana como uma dádiva do pintor, pois utilizou o "fue dada” para frisar a altivez da religiosa. Terá sido mesmo assim, quer dizer, o pintor deliberadamente pusera Sor Juana altiva? Simon Schama, na série $O$ poder da Arte, sugeriu mais de uma vez que o retratado participa da composição da cena do retrato, tem uma idéia daquilo que quer sentir ao se ver num quadro ${ }^{45}$. Quando caminhava pelo percurso do italiano Caravaggio, um quase contemporâneo de Sóror Mariana e de Sor Juana, Schama especulava acerca dos pedidos do retratado, do momento que a obra congelaria.

Para além da questão da interferência do retratado, está a idéia de transcedência. A transcendência seria sempre a qualidade mais desejada num quadro? Será que, por força do manejo das linhas, das cores, das dimensões, do foco, do jogo de luz e sombra, da aproximação com que se convida ou se repudia o espectador, do protagonismo que se dá a essa ou àquela personagem num conjunto, enfim, o pintor busca a transcendência? Schama nos levou a considerar essa dúvida, para que percebêssemos a convergência dos desejos de quem encomenda e de quem executa uma obra de arte.

À parte o brilhantismo que deriva do domínio técnico do artista plástico, os retratados têm um gosto e uma intenção mais ou menos comuns, porque são gostos e intenções que dizem respeito a uma época, a um lugar e a uma classe social, mais do que a uma pessoa singular. No século XVII, como Schama mostrou por meio das obras de Caravaggio e de Bernini, havia uma

\footnotetext{
${ }^{44}$ Camila Henríquez UREÑA, Obras y apuntes, 2006, p. 135.

${ }^{45}$ Simon SCHAMA, O poder da Arte, 2007.
} 
demanda do clero por obras de arte. O cardeal Francesco Maria Del Monte fora comprador de quadros de Caravaggio e depois ofereceu a ele um lugar em seu palácio para que convivesse com outros artistas da música e da poesia, enquanto pintava; um outro cardeal lançara Bernini na carreira artística e outro ainda, Scipione Borghese, tomara Bernini como artista privado. A aristocracia da Igreja queria possuir arte, sendo assim, mais de um papa estreitara relações com Bernini e o promovera. Gregório XV, por exemplo, fizera dele um cavaliere; Urbano VIII o tivera como amigo pessoal. O que Schama salientava é que a aristocracia da Igreja utilizara os artistas como divulgadores de uma mensagem política decente, aceitável, honrosa, tão forte quanto o ataque protestante às imagens nas igrejas. Era a defesa da fé católica. Em paralelo, os membros dessa aristocracia concebiam projetos mais egoístas. Papas e cardeais provocavam-se uns aos outros, na medida em que se tornavam donos de obras caras e bonitas, que fariam inveja aos outros.

A Nova-Espanha não era a Itália, centro da Igreja Católica e território privilegiado da escultura e da pintura ocidentais, mas sabemos que as monjas novo-hispanas até objetos de arte adquiriam para oferecer aos seus protetores nobres. De Sor Juana, por exemplo, restou a fama de boa negociante, do que se depreende que saberia apreciar e comprar, como sabia assegurar as posses do convento que havia servido como tesoureira mais de uma vez.

No quadro de Miguel Cabrera, o que foi posto em evidência? Uma figura humana mais iluminada do que as obras dispostas como pano de fundo, do que a própria mesa de trabalho, do que a cadeira onde se acomoda, sobretudo mais clara do que os elementos do alto do quadro, mãos e rosto tão alvos que contrastam com o próprio tecido negro da touca; figura central num mundo de 
letras, mundo de certo conforto, garantido pela presença de instrumentos senão alheios, pelo menos dispensáveis a uma religiosa numa cela de convento (o relógio, a pena, a estante); figura de religiosa, como se nota por causa do rosário e do medalhão da Ordem dos Jerônimos, mas uma religiosa elegante, cujo hábito está bem apanhado na cintura e faz dobras que dão idéia de leveza, mesma idéia que a mão direita transmite, pelo modo como toca o livro aberto.

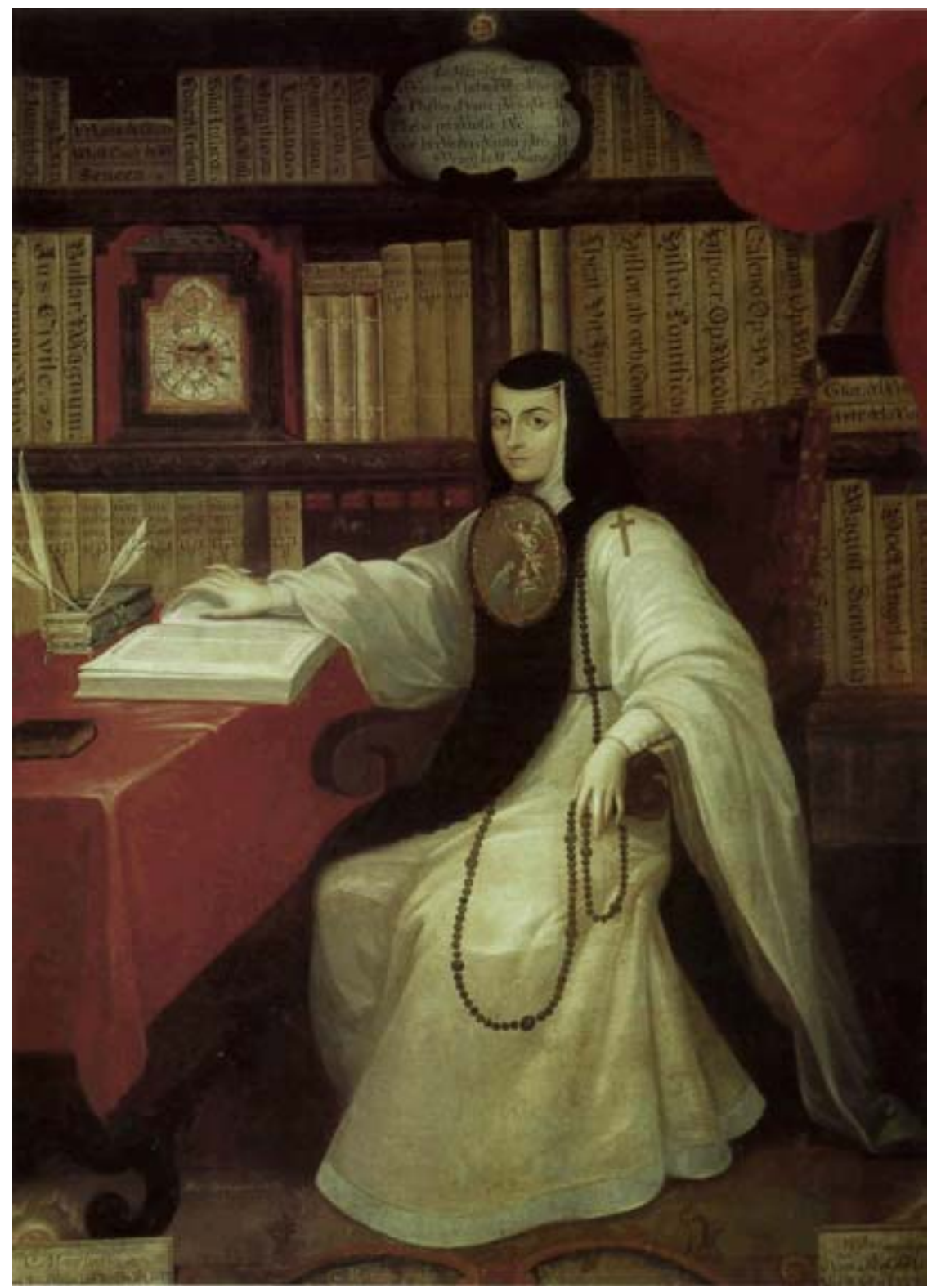

Fig. 1 - Sor Juana, por Miguel Cabrera (1750) 
E no caso de Mariana Alcoforado, qual terá sido a intenção dos pintores? Fiquemos com o trabalho de Massard, de 1771, portanto contemporâneo do trabalho de Miguel Cabrea, reproduzido na Fig. 1.

O desalinho da religiosa destoa muito do donaire de Sor Juana ${ }^{46}$. O corpo não está ereto, mas inclinado para a frente e para o lado. Numa pose mais masculina do que feminina, Sor Juana tinha as pernas afastadas; Sóror Mariana também as tem, mas a posição dos pés torna a figura mais feminina: um dos pés, está com a ponta virada para quem vê o quadro de frente e o outro está apoiado de lado, como ela Mariana pretendesse levantar de repente. O olhar também não se põe no observador do quadro, fixa-se no objeto que Mariana segurava (um retrato de Chamilly?) enquanto escrevia. A cinta igualmente está bem apertada à cintura, como a de Sor Juana, mas o hábito, que parece grande, tem pregas menos elegantes, ou pelo menos que não conferem a idéia de disciplina ou de segurança. A touca, que faz no topo da cabeça um vinco para dentro, e não uma curva convexa perfeita, como no caso do trabalho de Miguel Cabrera, pode ter sido a inspiração de Matisse. Numa série de litografias, ele faria retratos ou lânguidos ou levemente picantes, marcados por olhares expressivos e lábios bem delineados; nos quais o rosto de Mariana estava emoldurado com o desalinho, a graça e o mistério que a touca dava a ele ${ }^{47}$. E o pano de fundo de Massard? Ao contrário do que fez em outro quadro, neste se vê um recorte muito reduzido da janela, com a cortina aberta e apoiada em um divã ${ }^{48}$; uma mesa pequena e baixa

\footnotetext{
${ }^{46}$ A própria Sor Juana se via assim e assim o disse na Respuesta a Sor Filotea (Obras completas de Sor Juana Inés de la Cruz, IV, 2004, p. 455).

${ }^{47}$ Cf. Anexos, Fig. 5.

${ }^{48}$ Massard tem outro trabalho sobre Mariana Alcoforado, reproduzido nos anexos desta tese, no qual ela está de pé à beira da cama, mãos espalmadas e braços abertos, cada um numa altura (o esquerdo à altura da cabeça e o direito um pouco acima da cintura). O cabelo de Mariana está à mostra, solto, e a expressão facial é tensa, além de ligeiramente distante. A roupa mais uma vez tende para o desalinho. Não há um divã baixo e de encosto discreto, como na Fig. 2, mas uma grande cama com dossel, travesseiros e roupa de cama amarfanhada. Há uma cadeira também, as mesmas linhas retas nas paredes, e uma janela bem
} 
demais para quem escreve regularmente, mas que mesmo assim acomoda o

tinteiro e as penas. Há no aposento íntimo um apoio muito pequeno para os pés e

também um vaso de contornos ainda mais toscos que os do restante da obra. Nas

paredes, nuas, apenas linhas retas:

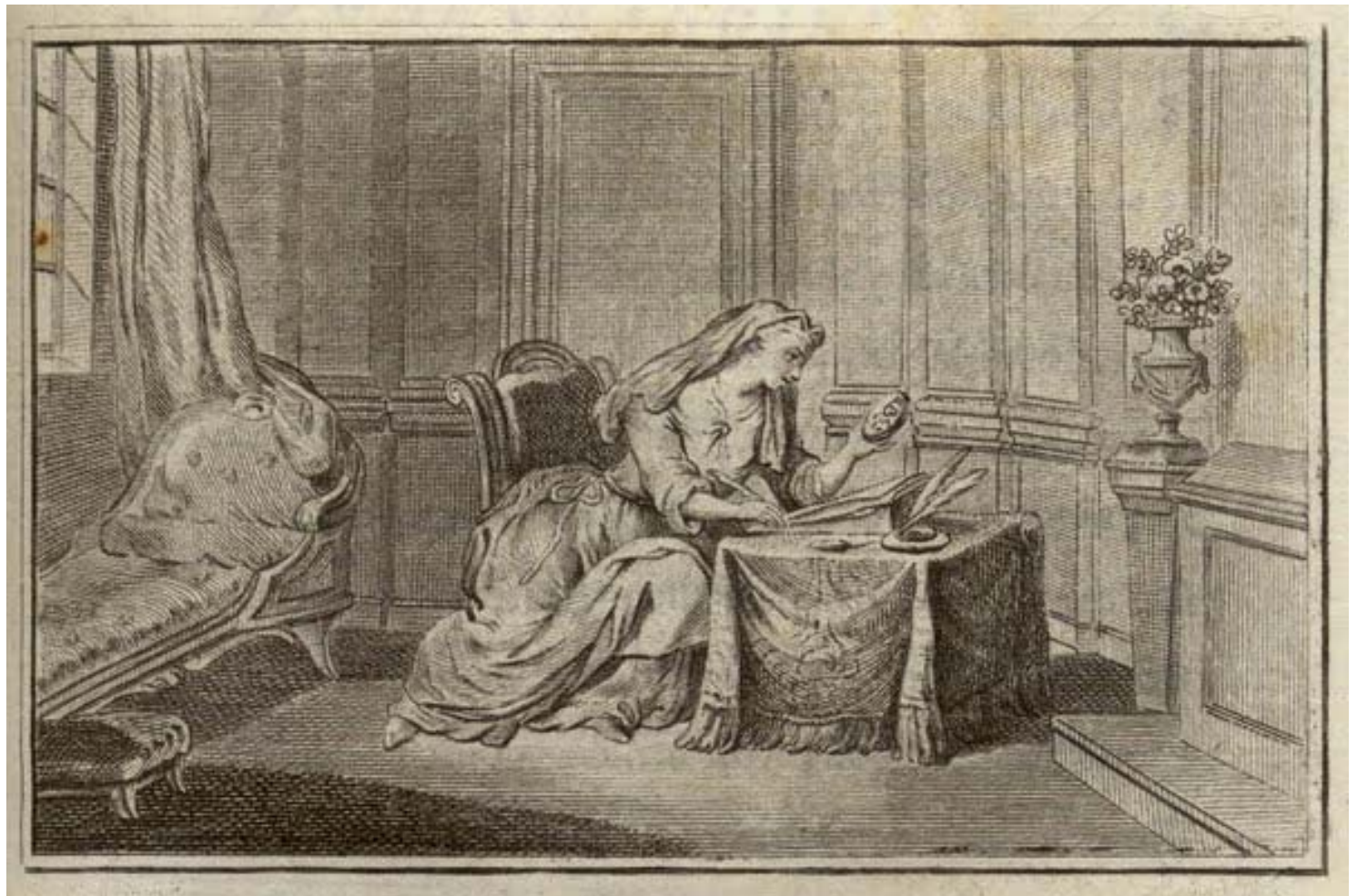

Fig. 2 - Sóror Mariana, por Massard (1771)

Para encerrar o tópico, lembremos apenas que, com a finalidade de situar a arte do século XVIII no que diz respeito ao pudor, Jean-Claude Bologne contou que os pintores ditos oficiais davam preferência ao que se pode chamar

aberta, de onde se vê parte de uma embarcação a vela (provável alusão aos navios nos quais tantos portugueses partiram, abandonando suas mulheres, na época dos descobrimentos marítimos). Um anjo se esconde na sombra que Mariana projeta, como que se protegendo. No lugar de um vaso que contém uma planta, este quadro de Massard tem um vaso pousado no chão, e dele saem muitas folhas pequenas, que até se espalham pelo chão do quarto, como se tivessem brotado ali mesmo. Vale a pena reforçar a idéia do barco associado ao abandono, pois ela já tinha aparecido na pintura de Coster, de 1716, também reproduzida no anexo desta tese: a remissão ao abandono das mulheres foi feita pelo pintor ainda com mais clareza, porque de um lado do quadro estava a embarcação e do outro uma cena supostamente rememorada por Mariana (o casal a conversar, ela sentada à cama e ele ajoelhado em frente a ela). 
de: “Arte do instante, do fugidio, que sugere mais do que mostra e que não cuida de ir até ao fim das suas promessas”49. Essa busca do cotidiano supriria a demanda, a curiosidade sobre o corpo nesse registro de pintura. Pensamos que de alguma forma o comentário se aplica à Fig. 2, uma vez que Mariana parece ter sido capturada de improviso por Massard, enquanto fazia aquilo que se tornara seu hábito: concentrar-se em Chamilly. Na intimidade o pintor tinha encontrado Mariana, na intimidade - que nada tinha de transgressora nem de obscena -, nós a encontramos.

Tanto de Sor Juana quanto de Mariana, fixou-se a idéia de que a mulher, afinal, era capaz de ocupar seu espaço com o excesso de conhecimento (a abundância de livros na cela seria índice desse excesso), com o improviso da intimidade ou o seu contrário, a cena forjada, mas sem rejeitar o exercício da escrita.

\section{Um diálogo ou "Ser e dizer"}

Porque fora perturbado o seu silêncio (e o seu vaivém interior), e porque as flutuações já davam cabo de qualquer certeza, Mariana começa a falar:

- Quem é você? Acaso uma estrangeira? É que não reconheço o que vestes.

Mas como a outra não dissesse palavra e muito menos parecesse comungar da sua mortificação, Mariana quase desiste da resposta. Esquece-se a divagar e a sentir, mesma falta e mesma abundância baralhadas. Nenhuma realidade interposta, nenhum novo nome para acomodar emoções.

\footnotetext{
${ }^{49}$ Jean-Claude BOLOGNE, História do pudor, 1986, p. 245.
} 
E Juana, que repassava argumentos, corria a memória a buscar razões para esta última e todas as perguntas anteriores. Pois já não confessara o bastante? Que mais queriam? Pensavam ouvi-la, agora, noutra língua? Privada dos livros, privada da pena, privada de direção, consente enfim, mais do que convencida, vencida:

- Não trago novas, não tenho que lhe diga, irmã. - Anda, sente-se bem, no íntimo, por ter dispensado o recurso a uma qualquer ironia, e aponta com as mãos tão finas:

- Então lês? - E alcança o livro da mesa de cabeceira.

O solar, o convento (e depois só a sua janela), os dias medidos pelas cartas, sem traçado ou sabor ou serventia. Estaria mesmo a ficar louca? Mas o livro, sim, o livro. A palavra a que se agarrar, agora que ela sabia:

- Deu-mo a senhora D. Brites, irmã neste convento, que já não sabia com que me entretivesse. Se o queres, dou-to, ficas com ele. És capaz de ler em português?

\section{(...)}

Mas dali não se via mar algum. Passassem todo o dia a admirá-lo, estariam apaziguadas. As palavras que o mar traria, sob a forma de marulho, de onda, de espuma, de maresia diriam a Mariana que aquele era o caminho para outras vidas, e a Juana diriam que a alma a aventurar-se na profundidade daquelas águas talvez fosse uma nova, quiçá a única, forma de conhecimento.

A paixão as tinha absorvido. E só lhes restava tempo para meditar. 


\title{
Cap. II - Dois Panoramas da Sexualidade e Algumas Pistas para a INTERPRETAÇÃO LITERÁRIA
}

\author{
"Um olho vigiava a minha vida. A esse olho ora eu \\ provavelmente chamava de verdade, ora de moral, ora de lei humana, \\ ora de Deus, ora de mim." \\ Clarice Lispector
}

As idéias e os discursos acerca da sexualidade, ou melhor, o panorama de idéias e discursos ocidentais acerca da sexualidade perspectivado por Michel Foucault, desafia-nos a superar explicações simplificadoras e taxativas, ao tentarmos compreender as restrições impostas à autoria de Sóror Mariana Alcoforado e à transgressão de Sor Juana Inés de la Cruz.

Para descobrirmos os fundamentos que permitem chegar a uma melhor compreensão da recepção da obra das duas escritoras, passaremos a relacioná-las a Michel Foucault e também a Judith Butler, filósofa e professora norte-americana.

Cumpre estudarmos em profundidade os discursos em torno da sexualidade e a voracidade com que historicamente nos submetemos a eles, uma vez que o referido filósofo francês tornou visível a tessitura da rede responsável pela repressão sexual. Foucault ainda nos leva a considerar as dualidades das sociedades que nos precederam. Ao mesmo tempo em que alardeavam a hipocrisia na forma de encarar a sexualidade, elas induziam à hipocrisia; aconselhavam e desaconselhavam o silêncio a respeito do sexo; eram prolixas nos detalhes da vida sexual, aquela sobre a qual todos deveriam manter silêncio; relatavam as formas de coerção e continuamente as exerciam. 
Nessa perspectiva crítica, a hipótese da repressão sexual iniciada após o século XVII foi contestada por Foucault em pelo menos três pontos. Há que ser considerada, segundo o filósofo, a dúvida de natureza histórica (teria mesmo acontecido uma acentuação da repressão, desde o século XVII?), a dúvida de natureza teórica (o mecanismo que age no campo da sexualidade é em essência um mecanismo de repressão?) e a dúvida de natureza política (a crítica à repressão de fato representa o avesso da repressão?).

Incidiu em um quarto ponto, fundamental para esta investigação, o exame cuidadoso de Foucault. Ele alertou para a necessidade de redefinir o que entendemos por poder, uma vez que o poder é indissociável do saber e ambos são, ao mesmo tempo, indissociáveis da sexualidade. Como o elo entre esses três campos é forte, devemos investir na análise do trânsito que eles promovem da esfera individual para a coletiva. É importante observarmos as técnicas utilizadas para controlar, isto é, para incitar e refrear, a vontade de saber sobre o prazer, uma vez que ela era atiçada e esvaziada, em cada cidadão.

Segundo Foucault, médicos, juízes, pedagogos entraram em cena no jogo social das promessas de felicidade feitas em nome do controle e da intervenção na vida sexual do cidadão. A Medicina circunscreveu a vida sexual, na medida em que qualificou comportamentos, criou rótulos, nomeou desvios e apontou doenças ligadas às práticas sexuais marginais. A justiça atuou no mesmo sentido, produzindo jurisprudência a partir de situações ditas “criminosas”. A educação determinou que, nas escolas, a instrução servisse para evitar excessos e, também, para caracterizar os excessos, para caracterizar o erro. Nas três frentes havia, enfim, profissionais que assumiam a tarefa de sinalizar 
cada uma das armadilhas sexuais e a existência de uma recompensa para quem caminhasse bem entre elas.

Foucault sustentou igualmente a idéia de que a sociedade imediatamente posterior a Sóror Mariana Alcoforado e a Sor Juana Inés de la Cruz consolidava procedimentos reveladores da grande atenção dedicada ao sexo como tema, muito embora antes e depois daquela época tenha havido controle do poder atribuído a quem almejava o saber. Por outro lado, essa sociedade pregava que o sexo tinha "o” segredo, “a” chave para a plenitude do homem, e se dedicava a esmiuçar tal segredo o mais que podia. Enquanto alimentavam a idéia de um gozo espetacular, estavam sustentando, valorizando a rede articulada para manipular o conhecimento e o acesso ao sexo. E o grande projeto que os enredava, em vez de impor obstáculos intransponíveis, regulava as posições, como num tabuleiro, para que os cidadãos não excedessem um limite com o qual seria custoso lidar.

A vida sexual de um trabalhador agrícola do século XIX, morador de uma aldeia, serviu a Foucault como exemplo do alcance da curiosidade e do controle que rodeavam as condutas individuais. Ele estivera à vontade com uma menina no bosque, como desta altura se supõe que fosse dado fazer àquela época, naquele pequeno povoamento, mas a história chegou aos juízes, aos médicos, aos peritos, pois toda e qualquer manifestação da vontade sexual tinha que ser exemplarmente acompanhada, teorizada e registrada pela linguagem. A essa corrente de ações pontuais, gerais e inesgotáveis Foucault chamou “erotismo discursivo generalizado" ${ }^{50}$.

\footnotetext{
${ }^{50}$ Cf. Michel FOUCAULT, História da sexualidade. A vontade de saber. v.1, 2005, p. 34.
} 


\section{Foucault e a prolixidade no século XVII}

Em exatamente treze páginas de seu primeiro volume sobre a sexualidade, Foucault cumpriu a tarefa que escolhera: negar a visão comum de que o sexo passou a ser mais severamente reprimido desde o século XVII. São as páginas $09,11,15,17,21,22,24,29,84,101,104,109$ e 131 aquelas em que há dados sobre o século XVII. Em lugar do ponto de vista aceite, Foucault conduziu nossa atenção para operações bem mais complexas, ligadas à intensificação do discurso sobre o sexo a partir do XVII. O filósofo postulou que por ser mais difícil dominar o sexo, os agentes do poder (entre os quais já mencionamos médicos, juízes e pedagogos) trataram de criar mais e mais situações nas quais o sexo deveria ser colocado em questão, como objeto central de análise.

No âmbito das condutas forçadas pela Igreja, a confissão apareceu como mecanismo de convencimento acerca de uma postura sexual adequada. Judith Butler, depois de Foucault, chamou atenção para o fato de que a confissão, em si, é dúbia, pode ser interpretada ou como ato de sujeição ou como ato de rebeldia ${ }^{51}$. Pensamos, então, que tanto um desejo de esvair-se das culpas e dos medos (que tem mais de libertação que de confissão), quanto um desejo autêntico de “arrumar” idéias, para se sentir participante nalgum evento, pode impulsionar quem procura confessar. Se vive uma situação ambivalente, por exemplo, pode confessar por meio de cartas, para dar vazão ao que a experiência ambivalente fez crescer. Em outras palavras: ou se curva perante o peso da

\footnotetext{
${ }^{51}$ Cf. Judith BUTLER, Problemas de gênero, p. 155. A autora fala a respeito de Herculine Babin, que em seus diários relatou o drama de um corpo nem de homem nem de mulher, a confissão a padres e a médicos e a conseqüente efetivação da sua transformação jurídica em homem. Acerca do mesmo tema, a confissão, já houve muitas outras opiniões, como a de D. Francisco Manuel de Melo, em Carta de guia de casados. À p. 104 da edição de 2003, estão as ressalvas do narrador ao convívio com o confessor: a mulher casada pode oferecer prendas ao confessor, pode ir às festas em que ele está presente, mas não deve aprofundar as relações com ele, de modo que o veja fora do ambiente em que os ambos têm um papel a representar.
} 
ambivalência e acede à autoridade para confessar (para não sofrer em solidão), legitimando essa autoridade, ou a ambivalência desperta um desejo de saber (saber de si) e acede à “novidade” do seu próprio discurso, sendo esta a rebeldia (ou o ato que liberta do outro).

E por que não, ver na escrita das Cartas portuguesas a manifestação de uma forma de rebeldia/ insurreição ${ }^{52}$ ? Uma parte da crítica tem evitado dar à figura histórica de Mariana Alcoforado o que pode ser uma identidade postiça; sendo assim, se não a devemos classificar como “autora” pertencente à literatura portuguesa, por que não evitamos também negar simplesmente a autoria das Cartas portuguesas? Ao examinarmos a tese alcoforadista, tese da autoria portuguesa, veríamos que ela pode ser construída a partir da associação com a rebeldia que, segundo acreditamos, tem sustentação. Portanto, nem a imposição postiça da autoria, sem recurso a argumentos fiáveis, nem a simples negação da autoria das Cartas portuguesas, como se a sociedade barroca portuguesa não comportasse uma resposta humana à repressão social e à reforma dos conventos depois do Concílio de Trento ${ }^{53}$.

Se Mariana Alcoforado de fato estava, por meio das cinco cartas, confessando ou se libertando, encaremos no mínimo a dúvida quanto ao motivo da revelação. Examinemos, em duas traduções, uma de 1974, outra de 1993, a

\footnotetext{
52 O termo "insurreição" já foi usado pela Doutora Rita Maria de Abreu Maia, na tese "O amor e a pena feminina. Escrita feminina e insurreição amorosa”, orientada pela Professora Doutora Teresa Cristina Cerdeira da Silva e apresentada à Faculdade de Letras da Universidade Federal do Rio de Janeiro em 2001: “(...) Mariana Alcoforado faz do homem amado, seu motivo de insurreição. Não age contra toda espécie de decoro por ele. Age contra a moral imposta por vontade própria. Não é ele que a incita à transgressão, é ela que a deseja... Sua luta contra o decoro realizou-a ela na linguagem, no processo de escrita” (pp. 93-94). Também encotramos os termos "aventura” ("Revelar-se ao outro, através da escrita das cartas, para além do desejo de anunciar o amor e denunciar as penas, vai constituir uma aventura de auto-conhecimento" (p. 94) e "radicaliza": "O discurso de Mariana radicaliza ainda mais esse lugar de fala, por ser epistolar e por se mostrar consciente de que há uma predisposição amorosa do sujeito que anseia pela reciprocidade espontânea da paixão”, carregados da mesma carga semântica (p. 95).

${ }^{53} \mathrm{O}$ assunto será explicado no próximo capítulo, a partir de texto de Mario ROSA para o livro O homem barroco, 1995.
} 
resposta encontrada por uma freira frente ao arrebatamento (palavra que ambas

as traduções escolheram) que a fazia desejosa de um corpo, de uma história com continuidade e de um diálogo ${ }^{54}$.

A comparação com alguns acontecimentos da vida de Sor Juana Inés de la Cruz é uma hipótese de aprofundamento desta faceta da investigação. Sóror Mariana Alcoforado pode ter vivido um romance com um estrangeiro de passagem por Portugal, como pode ter escrito as cartas para se libertar das dúvidas que a torturavam e, quem sabe, convencê-lo a levá-la para França; ao mesmo tempo em que falava com ele, ela se ia conhecendo através da escrita ${ }^{55}$. Pois foi isso que Sor Juana Inés de la Cruz fez: escreveu cartas em que se confessava (ignorante, ingrata, menos amorosa do que amada etc), dirigidas a alguém que a aconselhava e ouvia. Numa época em que imperavam a prudência e a discrição, num ambiente competitivo e tenso, ela recorreu ao bispo de Puebla, para externar opiniões difíceis de absorver, porque causadoras de alguma indignação, do ponto de vista religioso e masculino e também porque

\footnotetext{
${ }^{54}$ Sor Juana também descreveu o arrebatamento de que fora vítima: na Respuesta a Sor Filotea, associou esse estado ao silêncio; para ela, diante das obras colossais do Redentor, de tesouros que ultrapassam a capacidade humana, mais vale o calar. O argumento seria uma explicação para a inexpressividade dela perante a dívida que a publicação da Carta atenagórica criara.

55 Tomemos como exemplos de rebeldia pelo menos os seis seguintes excertos, extraídos da edição de Cartas portuguesas de 1993: 1) "E porque hei-de eu procurar esquecer todo o desvelo com que me manifestavas o teu amor?” (p. 17); 2) “(...) bateu de tal forma [a tua última carta] que parecia querer fugir-me para te ir procurar" (p. 17); 3) "Não enchas as tuas cartas de coisas inúteis, nem me voltes a pedir que me lembre de ti. Eu não te posso esquecer." (p. 18); 4) "É justo que suportes, ao menos, as queixas de desgraças que previ ao ver-te decidido a deixar-me.” (p. 22); 5) “Ai, mas que remédio... Não; prefiro sofrer ainda mais do que esquecer-te" (p. 23); 6) "És tu mais digno de piedade do que eu..." (p. 24). Havemos de ponderar, contudo, levando em consideração o contexto das frases. Logo em seguida ao excerto de número 1, por exemplo, Mariana diz que seria ingrata, se não desejasse tanto o amante, isto é, insere a sua rebeldia num discurso de conciliação e não de divergência. Por outro lado, após o excerto de número 2, ela reforça a idéia de rebeldia, por meio da palavra "recusava" ("recusava uma vida que tenho de perder por ti"). Combinando com o espírito do excerto de número 3, Mariana insere a palavra "acuso" ("Não me encontro em estado de pensar em vingança, e acuso somente o rigor do meu destino", p. 19). Antes de usar o argumento contido no excerto de número 4, ela lançou o substantivo "afrontas" "Creio que faço ao meu coração a maior das afrontas ao procurar dar-te contas, por escrito, dos meus sentimentos.”). A sequência da segunda carta, depois dos excertos de número 5 e 6 , sugere alguma contradição, porque Mariana dá mostras de submissão: "Ainda bem que me seduziste" (p. 24); "Um oficial francês, caridosamente, falou-me de ti...” (p. 25). Parece, ao mesmo tempo, retórica da rebeldia e retórica da figura miserável, já apontada no capítulo I como reflexo/influência de uma possível leitura da vida dos santos ou de uma possível apreensão dos ensinamentos da Retórica de Quintiliano.
} 
muito autênticas ${ }^{56}$. Uma mulher a reclamar o direito de interpretar as Escrituras estava agindo contra as regras, não se confessava atenta às palavras dos pregadores e dos santos para se submeter a todas elas. E se uma figura em evidência, cujos excessos estavam a ser tolerados há muito, como Sor Juana, expunha-se, por que não o teria feito assim também Sóror Mariana Alcoforado? Se uma autora aplaudida e protegida se arriscou, por que uma amante jovem não se podia rebelar, ante a ameaça de ver a rotina reposta e descontinuados a história e o discurso que o amante havia trazido para sua vida? O que nos confunde mais neste caso de dúvida é que Sor Juana, depois de confessar para transgredir, confessou para se sujeitar. Quando assinou a Petición, requerendo perdão, indubitavelmente se curvava com o ato.

Fora dos templos, enfim, a elite (e depois também as outras classes sociais) deixou-se capturar pela curiosidade e pela obediência às normas sexuais. Chegada à instância da família, a polemização acerca do sexo tomou o lugar da preocupação com o estatuto do casal, para então ganhar a esfera do corpo. Foucault afirmou que o corpo, nessa fase da história, era entendido como "máquina" (p. 131), no sentido de lhe serem exploradas as potencialidades (como as aptidões, as forças, as utilidades, a graça). Do corpo se falava em demasia, para que fossem suficientes a repetição e o reforço do perigo que ele representava.

\footnotetext{
${ }^{56}$ Na Respuesta a Sor Filotea, por exemplo, ela chegou a usar a forma verbal conjugada "confesar", depois de ter assumido que chorara ao receber a Carta atenagórica impressa, que não era digna do conhecimento (conhecimento da publicação ou aquele que a movia a ler, a escrever?), que tinha ficado confusa e envergonhada com o ato do bispo etc. Mais à frente neste mesmo texto, ela utilizou "confieso" duas vezes, para reconhecer que lhe faltava mais dedicação aos temas e aos textos sagrados, em prejuízo da dedicação que já existia aos temas e aos textos mundanos. E sem recorrer a esse verbo, declarou a veemência com que desde pequena havia se inclinado às letras, sentimento fortíssimo que resultava sempre em reprimendas e ameaças.
} 
A cadeia de mudanças relativas à sexualidade explicaria o nascimento de um campo de forças a que Foucault chamou "dispositivo de sexualidade". Tal dispositivo viria a substituir o dispositivo de aliança, organizado em torno de uma política sexual menos diversificada, mais rudimentar no seu interior. Se o dispositivo de sexualidade permitia controlar o cidadão de maneira que ele parecesse livre e próximo ao segredo que o sexo contém, o de aliança mante-lo-ia preso por elos mais inequívocos, como a fixação do casal heterossexual adulto e de "status" definido, como sendo o modelar. O dispositivo de sexualidade, enfim, manipularia o sujeito e, numa escala maior de abrangência, manipularia a população, pois tinha alcance global. Foucault utilizou o termo "ardil" (p. 41 e p. 60) para explicar o aumento da severidade com que esse dispositivo permitiu controlar o cidadão. E muito embora não estejamos, no presente capítulo, às voltas com a definição que nos cabe dar ao período barroco, é interessante que já nos preocupemos em associar essa característica do controle da sexualidade aos mecanismos internos do período referido, pois a ele eram muito caros os jogos, as imbricações, o ardil, justamente. Ao poeta barroco cumpria lidar com as regras de regulação literária e social, de forma a garantir sua respeitabilidade como intelectual e, para tanto, ele jogava ardilosamente, como ardilosamente se intensificou o domínio do saber por meio do controle da sexualidade.

Desde o século XIX, a crítica partidária da tese alcoforadista tem ressaltado no conjunto das cinco cartas que constituem a obra atribuída à freira portuguesa Mariana Alcoforado uma intensidade fora do vulgar, muito 
semelhante à das Cartas de Abelardo e Heloísa ${ }^{57}$. Essa crítica vem destacando

igualmente o que pode haver de feminino no texto das Cartas portuguesas.

Muito embora a noção de identidade feminina seja controversa, conforme

salienta Judith Butler ${ }^{58}$, é importante apresentarmos os argumentos arrolados ao

longo do tempo com o intuito de valorizar essa característica. Argumentos dessa

natureza estiveram presentes nos discursos dos adeptos da tese alcoforadista e

nos discursos de vozes dissonantes, assumindo em cada caso um desdobramento.

Os críticos que entenderam a profundidade dos sentimentos femininos como um

predicado das Cartas portuguesas associaram este predicado à autoria feminina.

\begin{abstract}
${ }^{57}$ No ano de 1870, Teófilo Braga inserira no volume Estudos da Idade Média um capítulo chamado "As cartas da religiosa portuguesa”. Não nos causaram estranheza os elogios feitos a Mariana Alcoforado, pois o crítico se preocupou em contextualizar as Cartas, explicando também um pouco da história da própria freira. Em 1888, Luciano Cordeiro lançou Soror Mariana, obra integralmente dedicada à freira portuguesa e que, por isso mesmo, comentaremos mais ao pormenor em outro ponto do trabalho. Resumidamente, pontuemos que ele ressaltou o gosto pela divulgação pública das epístolas, como abertura de caminhos para a curiosidade em torno da história de amor de "encanto particular na sua desordem" (p. 49). Em 1912, a Separata do $\mathrm{n}^{\circ} .53$ de Os novos trazia uma apreciação das Cartas portuguesas intitulada "Soror Mariana Alcoforado", assinada por Costa e Silva; destacamos os seguintes excertos: “(...) um imperecivel monumento - o mais vibrante cântico de amor da nossa língua, em que nitidamente se afirma um dos mais brilhantes espíritos femininos dos tempos modernos.” (p. 3), “(...) as epístolas de Mariana Alcoforado são um diadema de lágrimas cristalinas, pérolas que perfumam as de um dos mais belos e imorredouros livros da nossa literatura.” (p. 4), “(...) as cartas da freira alentejana são a Bíblia do amor, o livro da mulher portuguêsa [sic] pura e simples, de um temperamento ilimitadamente afectivo e infinitamente delicado.” (p. 14). À parte os excessos do autor na adjetivação e no emprego de advérbios de modo, subsiste a admiração pelas Cartas portuguesas. Já em 1923, Godofredo Ferreira publicava no Diário de Lisboa "1723-1923. Soror Mariana Alcoforado morreu há 200 anos. Notícia bibliográfica...”. A tônica era a mesma do texto de Costa e Silva, como podemos constatar nas seguintes fórmulas: "poema de amor-saudade e amor-desespero" (p. 4) e “(...) o especial encanto das suas cinco cartas, que são cinco chagas gotejando sangue” (p. 5). Nos textos de Fidelino de Figueiredo datados de 1918, 1920 e 1941, notamos mais uma vez o tom adotado pela crítica, ao comentar as cinco cartas de Mariana Alcoforado. No último dos três textos de Fidelino, inserido no volume Literatura portuguesa, encontramos: "Aparecendo inesperadamente num meio literário dominado pelo preciosismo formal, ainda que sem nunca perder um fino sentido estético e um agudo instinto psicológico...” (p. 211). Mais à frente, à página 213, o autor afirmava que a religiosa expressara com "emoção cálida o mundo revolto de sua alma" e que o conjunto das cartas era uma "página veemente". A. Sousa Gomes, em 1964, escreveu Madre Mariana Alcoforado, sua graça e seu amor. Lado a lado com notas biográficas e uma pequena fortuna crítica, o autor assim se exprimiu: "As suas Cartas são uma confissão a Deus.” (p. 7). Também demonstrou considerar a obra que estudamos "uma jóia literária de alto valor" (p. 7) e “(...) o abrir dum coração puro" (p. 13). Em 1978, Jacinto do Prado Coelho, no Dicionário de Literatura, $2^{\circ}$ volume, $3^{\text {a }}$ edição, defendeu a tese da autoria portuguesa, ao lembrar que as Cartas: “(...) ou resultam dum hábil artifício de quem algo conhecia do nosso país, ou denunciam a origem portuguesa do texto” (p. 527). O contraponto a estes posicionamentos está, de certa maneira, em Jorge de Sena, que no ano de 1961 escreveu um pequeno texto acerca da reedição das Lettres portugaises em França, pela Garnier. Embora ele explicasse que não era adepto da tese alcoforadista, no que ela tinha de elogio da alma portuguesa, pôs-se a favor de outro pressuposto dessa mesma tese. Apontou o refinamento do texto das cartas, a sua humanidade e a transcendência relativamente ao código barroco, afirmando sempre crer mais na origem portuguesa do que na francesa.

${ }^{58}$ Judith Butler, “Sujetos de sexo/ Género/ Deseo”, in Feminismos literarios, 1999, pp. 25-76.
\end{abstract}


De fato impressionam as declarações de Mariana por vários motivos, discriminados a seguir, numa tentativa de estabelecer relação com os dados extraídos da leitura de Foucault até este ponto.

A freira nascida em Beja, notadamente sem vocação religiosa, como já tivemos oportunidade de verificar em nota de rodapé do capítulo I, não só se constituía como sujeito ao conhecer a própria sexualidade, como invocava para si o prazer, após a separação corporal e o desprezo, como se até na forma de um prazer sádico ele devesse estar associado a ela, para não a esvaziar de repente. Mariana, por esse ângulo, confirma as palavras do filósofo, porque apaixonadamente, com insistência, buscara enunciar o que é uma freira a desejar:

"Se me fosse possível sair deste malfadado convento, não esperaria em Portugal o cumprimento das tuas promessas: iria, sem pensar em mais nada, procurar-te, seguir-te e amar-te por toda a parte $^{\text {59. }}$.

Da mesma forma ela aludira à vantagem que o amor de uma freira tem a oferecer, comparativamente ao de uma mulher não-professa:

"(...) compreendo bem que uma religiosa não pode, em geral, despertar grande paixão. No entanto, parece-me que, se nas escolhas que se fazem fosse possível entrar com a razão, haveria motivos de as preferir às outras mulheres: nada as impede de pensar incessantemente na sua paixão, nem são desviadas pelas mil coisas que no mundo dissipam e ocupam” ${ }^{\text {. }}$.

${ }^{59}$ Cf. Mariana ALCOFORADO, Cartas portuguesas, 1974, p. 19.
${ }^{60}$ Ibid., p. 89. 
Mostrara-se dedicada ao exame da relação entre homem e mulher, quando escreveu sobre a naturalidade com que um homem àquela época dava-se a conquistar. Na escolha do termo "tirano", aliás, Mariana deixara visível a supervalorização do sexo e a força das paixões, que predispõe a amar e a odiar, a encontrar o paraíso e o inferno no mesmo objeto:

"O procedimento que tiveste é muito mais o de um tirano apostado em perseguir do que o de um amante que só deve pensar em agradar" ${ }^{\prime \prime}$.

As cartas de Mariana são testemunhos da veemência com que o sexo passou a ser tematizado no contexto do século XVII. É particularmente interessante verificarmos a freira a aludir à incitação para fazer silêncio (que, antes de mais nada, como mostrou Foucault, inflamava a curiosidade):

"Quero que toda a gente o saiba, que já não faço disso um segredo e estou encantada por ter feito tudo o que fiz por ti, contra toda a espécie de conveniências" ${ }^{62}$.

Pautados pela leitura de Foucault, sabemos que Mariana Alcoforado é representante de uma sociedade que começava a priorizar o discurso sobre o sexo, que era, então, um discurso sobre o corpo:

"(...) imaginei que, quando passasses, ficarias contente se eu te visse melhor e se admirasse a tua destreza e a boa graça quando montavas o teu cavalo" 63 .

Sempre às voltas com os mesmos argumentos, para convencer o amado a dar sinal de que valorizava o conteúdo das cartas, ela chegara a reduzir

\footnotetext{
${ }^{61}$ Ibid, p. 61. Salientamos que, à p. 15, já havia aparecido o verbo “tiranizar”.

${ }^{62}$ Ibid., p. 33.

${ }^{63}$ Ibid., p. 67.
} 
todo o mistério daquela existência (ser filha, ser religiosa, ser mulher) a conhecer a paixão, a sentir-se dona de um segredo que justifica tudo, à liberdade, afinal que, como Foucault assegurou à última linha do livro consultado para este capítulo, é a maior promessa do dispositivo de sexualidade. Nas palavras dela:

" (...) toda a gente me falava em seu favor e, pela sua parte, fazia quanto era preciso para despertar o meu amor.

Mas, finalmente, regressei deste encantamento. Deume, para tanto, uma grande ajuda e confesso que dela tinha extrema necessidade" ${ }^{64}$.

O texto de Mariana Alcoforado faz crer que o sexo tinha sido eleito como alvo das preocupações e das palavras, a partir do século XVII. Ao invés de repressão, as cinco cartas mostram laços muito fortes com a sexualidade vivida na fase adulta, dotada, então, de uma dimensão ímpar. Mariana se satisfazia em estar apaixonada, em sofrer e sobretudo em proclamar que era alguém por força dessas descobertas nas quais o sexo estava presente. De acordo com alguns fragmentos das Cartas portuguesas, é coerente pensar que há inclusive um pouco de cumplicidade (e mesma dose de recriminação) no relacionamento da freira com Dona Brites (talvez uma protetora do Convento de Nossa Senhora da Conceição, de acordo com Luciano Cordeiro, retomado no paratexto de Nuno de Figueiredo ${ }^{65}$ ) e com outras personagens daquele caso. A noção de cumplicidade, já trabalhada na Introdução, pode ter predisposto Mariana a escrever e a enviar o texto, porque injetava força na atividade feminina:

"Algumas religiosas, que conhecem o estado deplorável em que me puseste, falam-me muitas vezes de ti ${ }^{\text {"66. }}$.

\footnotetext{
${ }^{64}$ Ibid., p. 99.

${ }^{65}$ Ibid., p. 113.

${ }^{66}$ Ibid., p. 35.
} 
Vale a pena lermos também o seguinte excerto:

"Nomearam-me, ainda há pouco, porteira deste convento. Todas as pessoas que me falam julgam que estou louca: não sei o que lhes respondo, e é preciso que as religiosas sejam tão insensatas como eu para me terem julgado capaz de qualquer trabalho" ${ }^{\text {, }}$.

E, ainda, o fragmento da p. 65:

"Toda a gente se apercebeu da mudança radical do meu humor, das minhas maneiras e da minha pessoa. A minha mãe falou-me disso, primeiro com aspereza e depois com uma certa bondade. Já nem sei o que lhe responda! Acho que lhe confessei tudo!

As religiosas, mesmo as mais severas, têm pena do estado em que me encontro $e$ até lhes inspira uma certa consideração e um certo respeito por mim."

E o da p. 81:

"(...) ela [Dona Brites] tomará todas as precauções necessárias, a fim de que eu possa ficar certa de que recebeu o retrato e as pulseiras que me deu".

Todos esses fragmentos são úteis, se quisermos pôr à prova a observação de Foucault a respeito da intimidade ou liberdade que existia entre professor e aluno ou qualquer outro tipo de mestre e seu discípulo, tendo em vista que outra moralidade estava em vigor naquela altura. O filósofo tocou neste ponto para mostrar que havia diálogo e intercâmbio entre pessoas de níveis hierárquicos distintos e de faixas etárias diferentes, embora já tivesse havido mais liberdade para isso. Ele estabeleceu um paradigma com o século XVI,

\footnotetext{
${ }^{67}$ Ibid., p. 31.
} 
lembrando inclusive a naturalidade de um expoente desse período, Erasmo de Roterdã. Em seus Colóquios familiares ${ }^{68}$, o autor aconselhara o discípulo a procurar uma boa prostituta. Mariana fez referência a conversas e a comentários concernentes ao sexo, passados sem muita cerimônia, com uma frontalidade que um investigador poderia estranhar, se não estivesse atento ao que disse Foucault.

\section{O sujeito e a fantasia de libertação em Butler}

Judith Butler, professora universitária de Literatura Comparada em Berkeley, Califórnia, filósofa pós-estruturalista, trabalhou com pontos caros às construções de Michel Foucault, de forma a, por exemplo, situar a escolha de termos - e naturalmente de políticas - no campo do feminismo.

Em artigo reproduzido em português pelos “cadernos pagu”, Butler aborda a questão do sujeito e, assim como Foucault, discute o que há do poder e de suas implicações nas teorias feministas ${ }^{69}$. As disputas políticas, preservado o contexto em que acontecem, devem ser colocadas sempre em primeiro plano, se o assunto for categorizar, refletir sobre movimentos, plataformas, definições.

Segundo Butler, constitui-se como sujeito aquele que conhece o seu próprio ponto de partida, aquele que reafirma posições teóricas até então úteis à formação dele. Sabendo-se dentro de um programa, o sujeito tem condições de questionar, de reorganizar. Como escreveu a autora, "Nenhum sujeito é seu

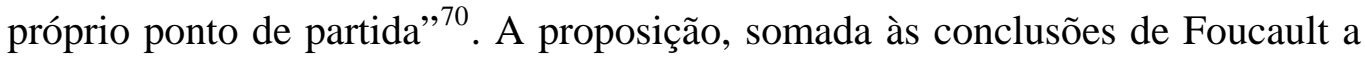
respeito das novidades características do século XVII e seguintes, leva-nos a

\footnotetext{
${ }^{68}$ Foucalut, à p. 29 de História da sexualidade, apontou a exceção que a atitude de Erasmo constitui, mas não chegou a informar precisamente que parte do texto de Erasmo estava a referir.

${ }^{69}$ Judith BUTLER, "Fundamentos contingentes: o feminismo e a questão do 'pós-modernismo'", cadernos pagu, (11) 1998.

70 Ibid, p. 24.
} 
indagar se a postura de passar a colocar o sexo no centro das conversas e relações teria oferecido oportunidade às escritoras aqui estudadas, de maneira que elas pudessem criar textos a figurarem como marcos naquele cenário e depois dele.

Valemo-nos, nesta reflexão, do estudo feito por Luciano Cordeiro, material que se esgotou em seis meses. Classificando o ambiente do lançamento das cartas de amor como "galante, artificioso e frivolo", apresentou-o também como típico de uma sociedade polida e literata. Interessa-nos sobremaneira que ele tenha explicado o fascínio que as cartas exerceram baseado na convicção de que soaram, aos olhos dos cortesãos, fruto exótico colhido em outras terras. O pesquisador teceu uma série de comentários que indicam em Mariana vaidade, sensualidade, dicção feminina e adequação ao gênero barroco. São traços associados ao perfil que a freira podia adotar e explorar naquele período histórico e literário, pois dariam a ela visibilidade, lugar de destaque. De maneira muito apropriada, Luciano Cordeiro dá a Mariana Alcoforado uma posição no seiscentos.

Se houve demanda de discurso sobre o sexo, a ela atenderam Sóror Mariana Alcoforado e Sor Juana Inés de la Cruz, cada qual num gênero textual e com uma expectativa de recepção. No caso da freira portuguesa, estão já expostos neste capítulo alguns trechos que revelam o quanto ela deu a conhecer das sensações e dos sentimentos que experimentava, sendo oportuno, mesmo assim, olharmos para a atitude de Mariana Alcoforado da perspectiva da autora de Andarilhas da alma, Margareth de Almeida Gonçalves, que falou em despojamento, no contexto de uma explicação acerca da epifania: 
"Trata-se de uma noção de experiência que escapa à razão e que precipita o sujeito para fora de si, em um processo de despojamento que, no extremo, aniquila o indivíduo para o mundo" ${ }^{11}$.

Vemos em Mariana Alcoforado sinais de uma revelação pessoal, mas para a sociedade que a conhecia ela decaía, isto é, era preferível tê-la de outro modo. Pode ser bonito para o leitor de hoje observá-la a ver-se mulher, porém a mesma lucidez que isso implica, entendida como bela ou não, não a tornava mais adequada, depois da revelação da experiência com Chamilly.

Acreditamos que é importante reafirmar o exemplo dado pelas duas religiosas do século XVII em mais um ponto definido por Judith Butler. A fim de retomar a questão do sujeito, ela prega:

"Em certo sentido, o sujeito é constituído mediante uma exclusão e diferenciação, talvez uma repressão, que é posteriormente escondida, encoberta, pelo efeito da autonomia. Nesse sentido, a autonomia é a conseqüência lógica de uma dependência negada, o que significa dizer que o sujeito autônomo pode manter a ilusão de sua autonomia desde que encubra o rompimento que a constitui" ${ }^{72}$.

Está em jogo a consciência do sujeito em reconhecer-se como peça num contexto cultural que o revela, mas também o limita. O sujeito, principalmente a mulher, encontra-se produzido e regulado de antemão. Faltando ao sujeito tal clareza, ele estará arriscado a ver na garantia de ação uma segurança de que em realidade não goza. Isso pode ter acontecido a ambas as escritoras de que tratamos, para as quais a sensibilidade, a matéria para a escrita e a ocasião para se envolverem com pessoas mais autorizadas a circularem

\footnotetext{
${ }^{71}$ Margareth de Almeida GONÇALVES, Império da fé, 2005, p. 15.

72 Judith BUTLER, "Fundamentos contingentes: o feminismo e a questão do 'pós-modernismo'", cadernos pagu, (11) 1998, p. 29.
} 
naquelas esferas talvez tenham enganado com uma perspectiva de assimilação mais amena ou mais libertadora advinda dos trabalhos por ela realizados.

Pesa a favor da linha de raciocínio de Judith Butler, linha que toca a violência:

"Como uma categoria que produz efetivamente o sentido político do que descreve, 'sexo' põe em funcionamento aqui sua 'violência' silenciosa ao regular o que e não é designável" ${ }^{73}$.

Em outro artigo reproduzido nos cadernos pagu, Butler chama a atenção para o fato de que "O Estado se torna o meio pelo qual uma fantasia se torna literal"74, o que nos faz retomar as histórias conhecidas de Sóror Mariana Alcoforado e Sor Juana Inés de la Cruz e este projeto de colocá-las no lugar de mananciais, fontes privilegiadas para a apreciação da literatura feminina. Parecenos que, quanto às opções de conduta sexual, ambas ousaram tornar discursivo e público (isto ao menos no caso da segunda) aquilo que o aparelho da Igreja - a funcionar como o Estado para elas - gostaria de assimilar de outra maneira. A confissão, já enunciada neste capítulo, talvez se prestasse mais ao controle que as ordens religiosas daquele período queriam ter. Tanto uma como outra escritora transcenderam o limite estabelecido e eis que a "fantasia" não pôde ser transformada numa versão literal. O que se seguiu à superação do limite foram reprimendas da parte das ordens religiosas ou da família.

Do lado mexicano esse mecanismo teve mais visibilidade, se lembrarmos que Sor Juana era defensora de uma política para a educação feminina. De fato, a disposição dela em criar um meio favorável à instrução das

${ }^{73}$ Ibid., p. 42.

${ }^{74}$ Judith BUTLER, "O parentesco é sempre tido como heterossexual?", cadernos pagu, (21) 2003, p. 234. 
mulheres, preocupação típica de uma mente erudita e exigente, encontra explicação em fatos relatados e em observações feitas por Octavio Paz, a saber: a literatura novo-hispana fora escrita por homens e lida por eles; às mulheres cabia escrever críticas de sermões, embora não estivesse aberta a elas a possibilidade de redigirem os sermões, gênero textual tão comum no Barroco; nos conventos femininos o nível intelectual era muito mais baixo do que nos conventos masculinos.

Em 1667, provavelmente aos dezoito anos, Juana Inés entrou na Ordem das Carmelitas Descalças, onde permaneceu somente por alguns poucos meses, provavelmente em decorrência da dureza dessas irmãs, a qual a afastaria de uma vida dedicada aos estudos.

Assim que ingressou na Ordem das Jerônimas, em 1669, Juana tomou parte em atividades teatrais e musicais do convento. A despeito delas e da função social desse e de outros conventos da época (as outras duas funções citadas pelo mesmo estudioso são a religiosa e a mundana, que tornaremos a referir no capítulo seguinte), a rotina era monótona e pouco cumpria do objetivo de congregar mulheres; as religiosas passavam boa parte do dia no isolamento de suas celas, protegidas por um aparato superior ao imaginado por leigos. Visitavam-se e a tais visitas Sor Juana aludiu em tom de queixa, uma vez que cada chegada de outra religiosa interrompia uma leitura, uma redação, um estudo, enfim ${ }^{75}$.

A julgarmos pelas cartas que ela enviava e recebia, trocadas inclusive com pessoas distantes daquele ambiente (em Espanha ou América), havia nela o

\footnotetext{
${ }^{75}$ Sor Juana Inés de la CRUZ, Obras completas de Sor Juana Inés de la Curz, IV, 2004, p. 452: "Reparé que en este tiempo hacía falta a mi estudio, y hacía voto de no entrar en celda alguna si no me obligase a ello la obediencia o la caridad...”.
} 
desejo por interlocutores ou mesmo "interlocutoras", palavra no feminino. Em março de 1691, a Respuesta a Sor Filotea revelava que Juana se sentia carente tanto de um mestre quanto de discípulos e que identificava nas mulheres sábias de época mais remota que a dela a hipótese para justificar o próprio interesse pelas Escrituras: "Ya se ve cuán duro es estudiar en aquellos caracteres sin alma, careciendo de la voz viva y explicación del maestro»76. Ela, uma mulher, rejeitava a propalada idéia de serem intelectualmente inferiores as mulheres, pois dessa forma precisamente projetava-se para a luz pública, distinguindo-se ${ }^{77}$. A religiosa enumerava exemplos femininos de participação memorável na Poesia, na Filosofia e em outras áreas. Sabedora de que sua condição de mulher a pusera no lugar de censurada no episódio da Carta atenagórica, expôs mais claramente o próprio ponto de vista, como, aliás, não tinha feito na criação poética.

A polêmica em torno da crítica ao Sermão do Mandato, escrito pelo jesuíta português Antonio Vieira, ilustra a relação Estado - fantasia (ou Igreja fantasia) e nos conduz mais uma vez aos pensamentos de Judith Butler acerca dos procedimentos de reconhecimento por parte da mulher.

Pe. Vieira era muito lido em Espanha e nas terras dela dependentes, como o Vice-reino da Nova Espanha. Sor Juana tomou conhecimento de uma

\footnotetext{
${ }^{76}$ Idem, p. 447.

${ }^{77}$ Lembramos os textos em que Rousseau foi redutor acerca da educação e das capacidades da mulher. Modernamente, foi Sarah Kofman quem chamou nossa atenção para os argumentos de Rousseau. Em "Os fins falocráticos de Rousseau”, ela comentou La nouvelle Héloise, Emile, Lettre à d’Alembert e outros textos, com a finalidade de explicitar a maneira como Rousseau associara a submissão feminina a um impositivo da Natureza. A esse exemplo de resistência ao protagonismo da mulher, podemos somar certas criações masculinas que, tendo público fiel (iletrado ou menos exigente para com a cultura letrada) e por isso reedições numerosas, acabaram por persuadir acerca da pouca confiança que a mulher merece. Eram textos volantes, divulgados em papel ou representados na forma de autos, de aldeia em aldeia. Citamos particularmente o caso de Baltasar Dias, escritor da ilha da Madeira referido por Inocêncio Francisco da Silva, Diogo Barbosa Machado e outros pesquisadores portugueses, em função da fama e do escasso brilho literário. Foi transmissor de um discurso sem dúvida misógino. A obra que, neste terreno, rendeu mais polémicas e adendos propostos por feministas e também por outros homens foi Malícia das mulheres, quintilhas que ocupam oito páginas e foram publicadas em Lisboa, no ano de 1640.
} 
publicação, relativa ao Sermão do Mandato, proferido em Lisboa, no ano de 1650. Propensa às reflexões sobre a natureza do amor (ela é autora de uma série de poemas ligados ao código do amor cortês, por exemplo), discordou de Vieira quarenta anos após ele ter pregado na Capela Real sobre o tipo de amor dos últimos dias de Cristo. Mais de uma vez rogou ao interlocutor, Manuel Fernández de Santa Cruz, o bispo de Puebla, que resguardasse o texto da leitura de outras pessoas, pois ao escrever ela estaria obedecendo a um conselho, a uma provocação dele.

É importante sabermos que para o padre Antonio Vieira, em termos de opinião e de exercício retórico também, a maior fineza de Cristo foi o ausentar-se, mesmo em face do amor que sentia pelos homens, ao passo que para Sor Juana a maior fineza de Cristo estava em morrer em louvor dos homens, criados à semelhança Dele. A religiosa refutou os argumentos do orador português relativamente a um segundo ponto, convicta do intento de Cristo, ao desejar ter o amor correspondido. Para ela, Cristo via benefício para os homens na retribuição do amor e, por isso, buscava tal retribuição. Vieira sustentara que Cristo não necessitava da retribuição para ele, mas queria vê-la de homem para homem. As discordâncias, enfim, indicam que "Con ideas y procedimientos que venían de los jesuitas, sor Juana atacó a uno de ellos y de los más ilustres"78 .

Diante do ataque a Vieira, o bispo de Puebla sentiu que ela atacava também o arcebispo do México, Francisco Aguiar e Seijas, amigo de Vieira. Decorreu daí que o bispo nomeou e publicou a Carta atenagórica para incomodar o arcebispo, oponente dele, do qual se diz, ainda, ser avesso às mulheres e ao teatro, numa época em que a mesma Sor Juana tinha uma peça

\footnotetext{
${ }^{78}$ Octavio PAZ, Sor Juana Inés de la Cruz o las trampas de la fe, 2003, p. 518
} 
encenada (Los empeños de una casa). Enquanto a religiosa pensava de maneira livre, a Igreja preparava contra ela investidas que além de anularem-lhe a fantasia, devem ter-lhe causado profundo temor.

Sustentamos, finalmente, que a liberdade negada a Sor Juana era consentida a Vieira, e acontecia de ser constantemente alimentada. No texto que introduz o leitor ao erudito e acadêmico debate travado entre Antônio Vieira e o padre italiano Girolamo Cattaneo, a filóloga Sonia N. Salomão descreve o eminente português como "um interlocutor precioso naquele ambiente [a corte da Rainha Cristina da Suécia]”79.

Mesmo se reconhecermos que Vieira estivera preso em Coimbra e viajara muito em conseqüência da perseguição perpetrada pelo Tribunal do Santo Ofício (o processo da Inquisição durou de 1663 a 1667), ainda teremos de ponderar que os italianos receberam-no entusiasmados, e que existiu uma sucessão de encontros nos quais ele divertia a corte, no elevado e criterioso estilo dominante ao longo do período barroco. Fugia de uma forma de objeção à sua trajetória, mas tinha amparo em outro círculo, respeitadas exigências tais como o aprendizado da língua italiana, por ele relatado em determinadas missivas. A inserção do padre em Roma, portanto, difere grandemente da desaprovação das palavras e dos atos de Sor Juana, desaprovação esta já exposta e explicada. Cumpre reiterarmos, enfim, a disparidade de condições em que se descobriram homens, por um lado, e mulheres, por outro, no tocante à flexibilidade para participarem dos seletos grupos culturais e políticos.

O discurso de gênero desenvolvido por Michel Foucault e Judith Butler, conforme examinamos, oferece indícios de um sistema que se auto-

\footnotetext{
${ }^{79}$ Antônio VIEIRA, As lágrimas de Heráclito, 2001, p. 44
} 
regula, com vistas a continuamente opor obstáculos ao ingresso da mulher no centro das decisões políticas. Mariana Alcoforado e Juana Inés de la Cruz, personagens do mundo barroco, figuras centrais deste estudo em nível de doutorado, estiveram de fato afastadas dos salões em que a identidade (postiça) de homens e mulheres era configurada.

Mariana terá vislumbrado a perspectiva de interferir nas definições, fossem religiosas, familiares, quiçá pessoais do local e da época em que viveu? Sabemos de uma luta de mulher contra o desconhecimento de si, tendo como instrumento as palavras. Testemunhamos os frutos dessa ousadia na voz de outros intelectuais e artistas. Até hoje eles podem ser compartidos e o são. Eis uma faceta que nos permite, justamente, classificar Mariana (mulher ou mito) como referência e como modelo de emancipação.

Em outro nível classificamos Juana Inés de la Cruz, que encontrou um grupo masculino de religiosos e de cortesãos a equilibrarem discursos e ações, conforme suas próprias exigências relativamente às relações indivíduoEstado-Igreja. Dele a escritora conheceu a versão polida e ilustrada, por ocasião da leitura de poemas dela que os fascinava, o que a colocou diante da dura experiência de conhecer, como reflexo da sua intromissão, a versão primitiva e punitiva do grupo, revelada após a exposição dessa correspondência trocada com o bispo de Puebla. Busquemos sustentação em Mário Rosa, que apontou essa fragilidade em Sor Juana: “O mundo se soror Juana Inés é um mundo extraordinariamente sugestivo, mas frágil, favorecido pelo Palácio e tacitamente permitido pela Igreja, que iria desmoronar-se...”80.

\footnotetext{
${ }^{80}$ Mario ROSA, O homem barroco, 1995, p. 189.
} 


\section{CAP. III - O CONTEXTO BARROCO}

\section{“(...) devemos ser caramelos, para que Deus nos goste” \\ Fr. António das Chagas}

\section{Argúcia em tempos de conflito de idéias}

Antes de levantarmos questões nucleares e pouco pacíficas sobre a literatura seiscentista e a vida nos conventos femininos no século XVII, pensemos na origem do nome "barroco" e na carga pejorativa que ele já suportou, sem esquecer das limitações que Severo Sarduy apontou neste método ${ }^{81}$.

Duas hipóteses são aventadas pelos estudiosos. Registramos as duas, começando pela sistematização feita a partir de outras fontes por Helmut Hatzfeld.

Depois de examinar pesquisas de Juan Corominas, Franco Venturi, Philip Butler e Marcel Bataillon, situadas nos anos 50 e 60 do século XX, Hatzfeld fez menção a uma pérola irregular, de formato oval e fina nas extremidades, e também à palavra latina "baroco”, criada no seio da Escolástica para indicar a figura que os termos de um silogismo desenhavam ${ }^{82}$.

Para sustentar a explicação do nascimento do nome entre os falantes de língua portuguesa, Hatzfeld relembrou o comércio de pérolas em Broatki, Goa, em torno de 1530, sob responsabilidade de portugueses há cerca de vinte anos naquela região. A qualidade sugerida por meio do nome era a de

\footnotetext{
${ }^{81}$ Severo SARDUY, Barroco, 1989, pp. 25-26: “Qualquer ensaio sobre o barroco abre com considerações sobre as origens da palavra (...) Os especialistas esgotaram a história de barroco, mas raramente denunciaram o preconceito persistente, mantido pelo obscurantismo dos dicionários...”.

${ }^{82}$ Helmut HATZFELD, Estudos sobre o Barroco, 2002, pp. 287-289.
} 
deformação em relação à pérola convencional, mais redonda. Não se tratava de indicar nem a raridade nem a beleza das peças, por exemplo, mas de depreciálas.

A evolução do uso do nome - registrada por Hatzfeld e por Sarduy apontava para um aumento da conotação pejorativa. Estranhezas de diversos níveis (físico, comportamental, financeiro) eram caracterizadas mediante o emprego do nome "barroco". Alguns dicionários associavam-no ao bizarro e, assim, aproximavam-no de traços arquitetônicos e pictóricos desviantes. Progressivamente, o nome passou a ser mais aplicado nas artes (Sarduy ressaltou o uso que a ourivesaria deu ao nome), do que resultou a substituição da carga negativa. Neste ponto diferem um pouco os dois estudiosos, porque Hatzfeld apontara uma positividade de que Sarduy desconfiou: "Foi então que o termo 'barroco' adquiriu seu moderno e positivo significado no seio de um grupo de filólogos clássicos e historiadores da Arte de Basiléia, que se negou a ver como únicas formas possíveis de arte as formas clássicas e renascentistas” (p. 289). Sarduy deu mais ênfase à dissimulação por trás da aceitação do nome, ao mostrar que em nosso tempo o barroco tem sido associado ao kitsch, como se o houvesse ajudado a criar.

Ainda segundo Hatzfeld, o termo "barroco" fixou-se no terreno da literatura, mesmo que em alguns países (França, Espanha e Itália são os países mencionados) existisse resistência em usá-lo largamente, porque ele estaria ligado aos extremismos de um movimento literário, à imaturidade desse movimento, na perspectiva dos historiadores da literatura desses mesmos países. 
As proporções irregulares da pérola vendida em Goa e o silogismo "baroco" convergiram, não sem preconceitos e variações, para a forma que conhecemos e aplicamos na literatura, a fim de indicar obras do século XVII.

Extrapolando a esfera da nomenclatura, falemos da gênese do movimento artístico, muito mais imbricada do que a própria nomenclatura do Barroco $^{83}$.

Na transição da Idade Média para a Idade Moderna, conta o historiador Arnold Hauser ${ }^{84}$, foram importantes e tiveram muitos desdobramentos o abandono de uma visão de uniformidade no campo da política, o abalo no equilíbrio entre Deus e o homem e as mudanças de perspectiva nas ciências. Maquiavel propusera em $O$ príncipe a idéia da adaptabilidade, da especificidade que justifica alteração de princípios e aplicação de uma moral num meio e de outra moral em outro meio ${ }^{85}$. Lutero contestara a autoridade da Igreja: a dura hierarquia que ela impunha afastava Deus dos crentes; a moral que ela pregava não fazia desses crentes homens mais generosos e capazes; o mérito individual não se devia medir consoante uma boa ação, mas

\footnotetext{
${ }^{83}$ Não temos a pretensão de recompor à perfeição o cenário no qual se moviam as duas religiosas seiscentistas, fazendo-o a partir da discussão das mudanças que levaram ao movimento barroco; esperamos reproduzir, sem planificar, algumas explicações para a ligação entre arte e ciência - uma vez que em Sor Juana Inés de la Cruz é possível identificar um interesse genuíno por teorias e instrumentos científicos - e para a crise da fé religiosa.

${ }^{84}$ Arnold HAUSER, Maneirismo, 1993. Não nos interessa de forma alguma a distinção entre Maneirismo e Barroco, até porque este livro de Hauser não propõe interpretações da obra de Sor Juana, nem a reivindica como obra maneirista, embora fale de criações de artistas do mundo hispânico (Dom Quixote é exemplo disso). Ficaremos com as leituras mais amplas que ele fez da política, da religião, das ciências e da filosofia no contexto europeu e com algumas chaves que forneceu para pensarmos na literatura do período histórico que antecedeu o século XVII. À p. 98, por exemplo, ele sugeriu que haveria no mundo que precede o de Sóror Mariana e de Sor Juana uma propensão ao narcisismo; Hauser comentava o narcisismo feminino a partir de algumas personagens do teatro inglês. Nas peças Hamlet e Otelo, Hauser via protagonistas movidos pelo narcisismo, mas tinha além disso um juízo mais abrangente sobre o tipo narcisista: "À primeira vista, a posição das mulheres numa sociedade masculina e patriarcal pareceria predestiná-las ao narcisismo”. Salientou, ainda, que a ambivalência está mesclada ao narcisismo, o que quer dizer que os heróis inteiramente fiáveis, porque positivos, começavam a ceder lugar aos heróis narcisistas, com alguns pontos mais obscuros ou mais questionáveis, ambíguos, enfim.

${ }^{85}$ Sor Juana, umas vezes alheia às idéias do seu tempo, outras vezes melhor situada nele, deve ter lido Maquiavel, porque aludiu ao tipo de raciocínio dele, ao argumentar na Respuesta a Sor Filotea: “(...) parece máxima del ímpio Maquiavelo...” (Obras completas de Sor Juana Inés de la Cruz, 2004, p. 453)
} 
de acordo com a generalidade da vida que o crente levava e com a relação dele com a graça divina. Copérnico descobrira que a Terra não era o centro de um sistema, mas que circulava em torno do Sol. Kepler não dispensaria a observação dos fatos concretos, porque a crença na divindade não explicava o funcionamento das máquinas nem os fenómenos estudados pelas ciências. Os métodos científicos passariam a depender de um maior empirismo, não podendo mais serem associados a desígnios divinos. A organização que regia o universo do homem renascentista, enfim, caracterizada pela repetição de um padrão (em cada esfera um centro concatenador), tornara-se instável, os homens estavam aprendendo a questionar e a relativizar de uma maneira que punha em evidência os conflitos. A literatura de épocas posteriores, neste caso a do século seguinte, guardaria essa componente meio irreverente, aflita, mais pragmática, como se pode notar em Blake: “Uma só Lei para o Leão e o Boi é opressão”»86.

Desconcertado e ansioso por apoiar-se em novas certezas, o artista barroco que se viu impregnado das alterações de sentido e de rota em nível político, religioso e científico, passou a conferir um papel importantíssimo aos sentidos. Insatisfeito com eles também, especulava sempre mais, ampliava seu poder de visão, colocava diante de si um espelho, uma imagem para ler o mundo. Era aliciante, naquele momento histórico, atingir as essências, reconhecer o todo ao qual estavam filiadas cada uma das partes que ele

\footnotetext{
${ }^{86}$ Harold BLOOM, O cânone ocidental, 2001, p. 54. O enquadramento da citação de Bloom era o seguinte: afirmar a posição central de Shakespeare no cânone ocidental, pelo recurso ao que esse autor soube explorar, a "psicologia da mutabilidade". Shakespeare, ao contrário de Blake, era do mesmo período que as escritoras que estudamos, era europeu, e sobre ele podem ter agido as mesmas ondas de mudança que sobre elas, muito embora cadenciadas por outros fatores locais (religiosos, sociais, políticos, filosóficos). Se queremos reunir dados para fundamentar a idéia de narcisismo ou de alguma exuberância na assunção de pontos de vista transgressores ou menos colados ao papel social pré-definido, seja na própria voz ou na voz de um eu lírico, falar em Shalespeare e em Blake, aproveitando a deixa de Hauser e as teorias de Bloom, faz algum sentido e vai ao encontro do que expusemos de Octavio Paz e de Benedito Nunes na introdução e no capítulo I desta tese: nossas duas religiosas tinham traços narcisistas e eles têm influência na produção escrita, na opção por inaugurar ou continuar um discurso.
} 
enxergava e nas quais ele se buscava ${ }^{87}$. Ele percorria o caminho das analogias, das metáforas, dos recursos estilísticos, para captar algo da essência; o conflito de identidade a que chegara o obrigava a seguidas tentativas de apreender os objetos.

Lembremos que a crise política, religiosa/espiritual e científica do Barroco tinha gerado uma necessidade de expressão dual, de relativização, de uma perspectiva trágica na compreensão da vida e de alguma disposição para o desfile festivo, para a transformação das inquietações em rituais comunitários. A perturbação e a tensão oriundas da luta entre o espírito religioso e o racional deram um tom ao Barroco. O interesse metafísico ficava evidente na atenção que artistas dedicavam à intensidade, às paixões, ao desejo sexual e, inversamente, à melancolia e ao desfecho trágico do ser humano. A pompa do movimento artístico, por outro lado, servia bem às necessidades contra-reformistas de exaltação do mistério religioso e de salvação do homem.

Todos os planos que referimos (o político, o religioso, o científico e o filosófico) pareciam convergir para uma mudança na arte, mas, mesmo diante da serenidade que essa acomodação dos conceitos traz, há que ser observada a discordância de alguns intelectuais quanto ao tipo de explicação mais ou menos consensual que acabamos de resumir. Octavio Paz, depois de dar as mesmas razões para o aparecimento do Barroco, fez questão de apontar também uma dinâmica de fatores que só diz respeito à história da arte. Estava, de certa forma,

\footnotetext{
${ }^{87}$ Montaigne, cujos trabalhos filosóficos mais importantes começaram a ser publicados a partir de 1580 (cerca de noventa anos antes das Cartas portuguesas e mais ou menos cem anos antes de El sueño), é mencionado como um pensador que ilustra bem as mudanças que refletir-se-iam nos textos literários barrocos. Acerca das relações que um leitor podia fazer ao examinar livros e situações concretas, escreveu: “(...) Tiro à sorte o primeiro argumento. Todos são bons para mim. E nunca me esforço por os apresentar inteiros. Pois a nada vejo o todo. Não cumprem, aqueles que nos prometem mostrá-lo" (MONTAIGNE, Dos livros, 1999, p. 16). Era o sinal da dúvida que marcaria o século seguinte.
} 
repetindo as palavras de Alfonso Méndez Plancarte ${ }^{88}$. Não exploraremos esse tipo de explanação porque, como já afirmamos, a distinção entre movimentos adjacentes que suscitaram debate mais prolongado e complexo, como o Maneirismo e o Barroco, não chegaria a interferir nos resultados desta pesquisa. Porém, mais do que evitar uma linha de raciocínio que parece ineficiente, lembramos que existem explicações mais gerais para o surgimento dos movimentos artísticos, como a do revezamento entre uma tendência clássica e outra reativa ao classicismo. Preferimos, face à prodigalidade de explicações, ficar apenas com mais duas ou três notas teóricas sobre o Barroco em Portugal e em Nova-Espanha, partindo em seguida para a interpretação dos textos.

Sendo assim, antes de iniciar a leitura de uma parte da produção textual de Sóror Mariana e de Sor Juana, ligando-as aos eventos barrocos e à importância da imagem, temos de lembrar que em Portugal os escritores barrocos mantinham viva a tradição cultivada em outros países europeus ${ }^{89}$. De acordo com Isabel Morujão, eles procuravam “(...) formar um discurso engenhoso, construído muitas vezes em torno da prática do conceito, esse processo revelador de nexos insuspeitados ou não habituais entre objectos e palavras, entre realidades normalmente não relacionáveis”90, numa época de riqueza proporcionada a Portugal pelo ouro e diamantes brasileiros. “À NovaEspanha o movimento tinha chegado por derivação, isto é, como objeto cultural

\footnotetext{
${ }^{88}$ No paratexto do volume I das Obras completas de Sor Juana Inés de la Cruz, 2004, Plancarte diz que Renascimento e Barroco são diferenciáveis por razões estéticas, não interferindo qualquer motivo ideológico ou humano.

${ }^{89}$ Ana HATHERLY, A casa das musas, 1995, p. 127: “À medida que vão surgindo na actualidade trabalhos de divulgação desse género de obras [textos-figurados], é particularmente instrutivo verificarmos como os modelos se repetiam por toda a Europa com uma fidelidade notável, e ao mesmo tempo observamos até que ponto a criatividade individual conseguia manifestar-se, não obstante a rigidez dos preceitos".

${ }^{90}$ O comentário tinha o propósito de apresentar a obra e a técnica de Fr. António das Chagas e está no livro que Isabel Morujão editou: Cartas espirituais, 2000, p. 25.
} 
passado da metrópole para a colônia, o que não implicou em perda da qualidade nem em apego excessivo a um único poeta espanhol. O modelo mais copiado fora Gôngora (Sor Juana também o imitava), mas os poetas novo-hispanos buscavam igualmente Quevedo, Calderón, Alarcón e, se recuassem mais no tempo, chegavam também a Garcilaso e a San Juan de la Cruz.

\section{O olhar e a folha de papel}

No período barroco, visto agora de uma perspectiva menos teórica, havia festas e comemorações para a consagração de espaços destinados ao encontro de fiéis e de religiosos, havia grandes e teatrais procissões, havia cortejos. Por meio da lembrança desses eventos que entravam pelos olhos dos homens barrocos, realçamos o caráter lúdico e ostentatório do século XVII, porque esse caráter encontrou projeção na criação literária. Complexo, contraditório e intenso, o homem barroco estava moldado para aceitar as festas, a pompa, a sofisticação. Visual, vivaz e avassaladora, a natureza barroca estava nas manifestações coletivas e no exercício solitário das escritoras.

Affonso Ávila registrou a participação de Sor Juana Inés de la Cruz em dois episódios desse tipo, sendo o primeiro deles a escritura de um "longo poema descritivo"91 sobre um convento e o segundo a incursão num grupo de poetas reunidos pela Universidade do México em honra da Imaculada Conceição, no ano de 1682. À altura de dividir com outros poetas a tarefa de escrever poemas de cunho religioso voltados para a Imaculada Conceição, Sor

\footnotetext{
${ }^{91}$ Affonso ÁVILA, O lúdico e as projeções do mundo barroco I, 1994, p. 146.
} 
Juana estava no auge do seu reconhecimento intelectual, lida e admirada em outras terras $^{92}$ :

"Entre 1680 y 1690 su vida literaria y mundana alcanza la máxima intensidad: la tertulia de San Jerónimo, la amistad con María Luisa, las comedias e las loas, los poemas cortesanos y los eróticos, la incesante correspondencia con colegas y admiradores de Madrid, Sevilla, Lima, Quito".

Havia no Barroco algo que podemos chamar de circularidade, ou seja, o movimento artístico tinha uma faceta do pensamento aristotélico (ainda em voga no século XVII) que determinava alguns procedimentos formais da pintura para a poesia. Era a mútua correspondência entre pintura e poesia, no intervalo entre os séculos XVI e XVIII. Os poetas copiavam o que os pintores produziram e produziam, em obediência a um preceito segundo o qual ver era olhar com o intelecto. A poesia, assim, produzia efeitos visualizantes, almejando ser como a pintura. Nesse sentido, os poemas barrocos eram emblemáticos.

Para verificarmos em que grau o apego às imagens fez parte da obra poética de Sor Juana, observemos alguns poemas, sabendo que o levantamento distribuído nos próximos parágrafos não é nem se pretende exaustivo. Referimos em primeiro lugar uma décima ${ }^{93}$ escrita para acompanhar o retrato enviado a um destinatário não nomeado no texto. É o poema de número 102:

\footnotetext{
"A tus manos me traslada

La que mi original es, Que aunque copiada la ves,

No la verás retratada:

En mí toda transformada, Te da de su amor la palma; $Y$ no te admire la calma $Y$ silencio que hay en mí,
}

\footnotetext{
${ }^{92}$ Octavio PAZ, Sór Juana Inés de la Cruz o las trampas de la fe, 2003, p. 553.

${ }^{93}$ Sor Juana Inés de la CRUZ, Obras completas de Sor Juana Inés de la Cruz, I, Lírica Personal, 2004, pp. 239-240.
} 
Pues mi original por ti

Pienso que está más sin alma.

De mi venida envidioso

Queda, en mi fortuna viendo

Que él es infeliz sintiendo,

$Y$ yo, sin sentir, dichoso.

En signo más venturoso,

Estrella más oportuna

Me assiste sin duda alguna;

Pues que, de un pincel nacida,

Tuve sér com menos vida,

Pero con mejor fortuna.

Mas si por dicha, trocada

Mi suerte, tú me ofendieres,

Por no ver que no me quieres

Quiero estar inanimada.

Porque el de ser desamada

Será lance tan violento,

Que la fuerza del tormento

Llegue, aun pintada, a sentir:

Que el dolor sabe infundir

Almas para el sentimiento.

$Y$ si te es, faltarte aqui

El alma, cosa importuna,

Me puedes tú infundir una

De tantas, como hay en ti:

Que como el alma te di,

$Y$ tuyo mi sér se nombra,

Aunque mirarme te asombra

En tan insensible calma,

De este cuerpo eres el alma

Y eres cuerpo de esta sombra."

As relações que Sor Juana estabeleceu nos quarenta versos do poema

102 entre o que é natureza e o que é obra do sentir e do entregar-se (também ditos ou como original e cópia ou como corpo e retrato), o que tem alma e o que foi destituído da alma por causa da falta que o objeto de amor faz, o que é feliz sina e o que é sentido como dor, aquele que foi esvaziado por dar-se a quem ama, mas que ainda assim admira a completitude do ser amado etc, ilustram muito bem o domínio da poeta e a ligação do homem barroco aos jogos conceituais. 
A predileção do homem barroco por tudo o que os olhos podiam captar e examinar fica mais especificamente demonstrada por Sor Juana através da sugestão reiterada que vem de “retratada”, “pincel”, “pintada”, “mirarme” e “sombra”. Mas temos que sublinhar, também, a profundidade que ela nos soube transmitir, ao abordar o tema da solidão, que neste caso se apresenta sob o silêncio de uma imagem (“y no te admire la calma /y silencio que hay em mí”) e na potência do desamor ("Porque el de ser desamada /será lance tan violento, /que la fuerza del tormento /llegue, aun pintada, a sentir”). Vale lembrar que Alfonso Méndez Plancarte, à p. 496 do volume I das Obras completas de Sor Juana Inés de la Cruz, associa a pessoa não nomeada à Marquesa de Laguna. Na interpretação dele seria ela, então, a destinatária do retrato de Sor Juana e do poema que apóia a leitura dele, ela é que receberia essa homenagem, delicada declaração de admiração e de comunhão. Em outros casos, Sor Juana usou o nome Lise para substituir o da amiga nos poemas.

Em segundo lugar, transcrevemos um romance ${ }^{94}$ a respeito de pintura feita para a Condessa de Galve, esposa do vice-rei Gaspar de Sandoval Cerda Silva y Mendoza:

\section{"El soberano Gaspar}

Par es de la bella Elvira:

Vira de Amor más derecha, Hecha de sus armas mismas.

Su ensortijada madeja Deja, si el viento la enriza, Riza la tempestad, que encrespa Crespa borrasca a las vidas. De plata bruñida plancha, Ancha es campaña de esgrima; Grima pone el ver dos marcos, Arcos que mil flechas vibran. Tiros son, con que de enojos, Ojos que al alma encamina,

\footnotetext{
${ }^{94}$ Ibid., pp. 119-120.
} 
Mina el pecho, que cobarde

Arde en sus hermosas iras.

Árbitro, a su parecer,

Ser la nariz determina:

Termina dos confinantes,

Antes que airados se embistan.

De sus mejillas el campo

Ampo es, que con nieve emprima

Prima labor, y la rosa

Osa resaltar más viva.

De sus labios, el rubí

Vi que color aprendía;

Prendía, teniendo ensartas,

Sartas dos de perlas finas.

Del cuello el nevado torno,

Horno es, que incendios respira;

Pira en que Amor, que renace,

Hace engaños a la vista.

Triunfos son, de sus dos palmas,

Almas que a su sueldo alista;

Lista de diez alabastros:

Astros que en su cielo brillan.

En lo airoso de su talle,

Halle Amor su bizarría;

Ría de que, en el donaire,

Aire es todo lo que pinta.

Lo demás, que bella oculta,

Culta imaginaria admira;

Mira, y en lo que recata,

Ata el labio, que peligra."

No texto 41, há a figura de linguagem a que chamamos eco, que confere ao leitor a sensação de estar diante de uma cascata: o nome Gaspar, por exemplo, aparece no final do primeiro verso e é reduzido logo no início do segundo, resultando em "par”; “madeja” transforma-se num detalhe, em “deja”; “plancha” em "ancha” e assim sucessivamente. O sentido global do texto dá suporte aos exercícios estilísticos de Sor Juana e por isso o nome dela sobressaía naquele meio e ainda hoje sobressai, sendo hoje mais larga a esfera de influência dela. Pois não se trata de cultivar meramente o artifício, trata-se de refletir com todos os meios disponíveis - os mais difíceis e os mais fáceis - num determinado 
código, a densidade das realidades calculadas pela poeta. As referências visuais em si apontam para a altivez e para o desejo erótico: estão no amor resoluto do casal, no frisado do cabelo, na dureza do metal, no vermelho dos lábios convidativos; junto com a graça (das maças do rosto, das pérolas), esse amor cria da "bella Elvira” um retrato de mulher inflamável, irresistível, par destinado a Gaspar. Cabe ainda uma nota para o caráter ilusório da visão, apontado por Sor Juana no verso trinta e dois (“hace engaños a la vista”): a brancura do pescoço de Elvira é tão cálida, que se vê ali frio e calor, bem onde brota renovado o encanto, a admiração do observador por ela.

Vem em terceiro lugar dentro de nossa enumeração uma endecha ${ }^{95}$, a respeito de pintura feita para a Condessa de Galve, personagem da corte que volta a instigar o exercício poético de Sor Juana, antes associado à Condessa de Paredes:

\author{
“Con los Heróes a Elvira \\ Mi amor retrata, \\ Para que la pintura \\ Valiente salga. \\ Ulises en su pelo, \\ Con Alejandro: \\ Porque es sutil el uno, \\ $Y$ el otro largo. \\ Un Colón es du frente \\ Por dilatada, \\ Porque es quien su Imperio \\ Más adelanta. \\ A Cortés y Pizarro \\ Tiene en las cejas, \\ Porque son sus divisas \\ Medias Esferas. \\ César son y Pompeyo \\ Sus bellos ojos, \\ Porque hay guerras civiles \\ Del uno al otro. \\ Es su proporcionada \\ Nariz hermosa
}

${ }^{95}$ Ibid., pp. 208-209. 
Aníbal, porque siempre

Se opone a Roma.

Alencastro y Ayorque

Son sus mejillas,

Porque mezcladas rosas

Son sus divisas.

A su boa no hay Héroe,

Porque no encuentro

Com alguno que tenga

Tan buen aliento.

Es su bien torneado

Cándido cuello,

Hércules, pues él solo

Sustenta el Cielo.

De Scévola las manos,

Aunque nevadas,

Son: pues en ellas siempre

Tiene las brasas.

Los pies, si es que los tiene,

Nunca los vide;

$Y$ es que nunca a un Valiente

Los pies le sirven."

O retrato 80 tem outros contornos, diversos dos brevemente reportados neste capítulo. Para cada ponto alto da figura da Condessa de Galve, Sor Juana procurou apontar um termo de comparação nos grandes homens das guerras e das batalhas que a história imortalizou. Mereceram destaque, por exemplo, o cabelo, o nariz, as mãos dela, tão memoráveis quanto o melhor de Ulisses, de César, de Hércules... Algumas comparações foram evitadas, para que o leitor ficasse com a natureza sublime da mulher retratada: “A su boca no hay Héroe, /porque no encuentro /con alguno que tenga /tan buen aliento”.

Lido em paralelo com o poema de número 41, o efeito é muito semelhante, isto é, Elvira soa destemida, firme, quase atlética, como aparecera no outro poema. A palavra "valiente”, grafada deste modo e depois com inicial maiúscula, não está na primeira e na última estrofes por acaso. As comparações enriqueceram este poema 80, visto que o resultado alcançado por meio de versos 
mais longos, no caso do texto 41, é parecido com o deste caso, em que a métrica ditou versos mais curtos.

Em quarto lugar, destacamos um “ovillejo”96 de que transcreveremos apenas os versos úteis para apresentar o poema em termos de apego à expressividade da visão. Com relação ao tema desse texto de número 214, podemos destacar a tradição poética votada à descrição das cores, das flores, dos brilhos, da beleza, enfim. Essa tradição é ao mesmo tempo reforçada e criticada, quer dizer, somos informados de nomes (está lá Garcilaso de la Veja, poeta espanhol do século XVI, introdutor da poesia do Renascimento na Península Ibérica: “ya no las puede usar la Musa mía /sin que diga, severo, algún letrado /que Garcilaso está muy maltratado / y em lugar indecente”, p. 321), somos informados dos usos mais recorrentes nos poemas do passado, que também já se concentravam na exploração desse tópico ("Que entonces era el Sol nuevo, flamante, /y andaba tan valido lo brillante, /que el decir que el cabello era um tesoro, / valía outro tanto oro”, p. 321). Nomes e usos são discriminados para que dimensionemos as tarefas advindas do apego à visão: ele tem obrigado os poetas do período da elocução deste poema a esmerarem-se e a emularem. Sor Juana diante desse peso ironiza, como se o cultivo da tradição fosse descabido, mas está ela mesma a cultivar a tradição. A leveza com que ela aborda o tema talvez seja o diferencial; percebemos essa característica, ao lermos versos em que ela se ri das convenções - que sabe de cor e repete oportunamente -, demonstrando espírito elevado ("Mas no pienso robar yo sus colores; /descansen, por aquesta vez las flores: /que no quiere mi Musa ni se mete /en hacer su hermosura ramillete”, p. 321). As imagens que ela oferece são

\footnotetext{
${ }^{96}$ Ibid., pp. 320-330.
} 
engraçadas, caricaturais, sem deixarem de ser bem conseguidas, como se lê à p. 322: "lo que es jubón, ajustan a ropilla,/ o hacen de unos centones/ de remiendos diversos, los calzones;/y nos quieren vender por extremada,/ una belleza rota y remendada”.

Convém ressaltar alguns versos em tom ainda mais descontraído que os supracitados: "El diablo me há metido em ser pintora” e "Mas que esta tentación me quita el juicio”, ambos presentes na p. 320. São exemplos do travo com que a poeta confeccionou o poema. Assim apresentado, o ofício do poeta soa menos sisudo e até risível, já que ele atenderia a um impulso que pouco tem que ver com o ser tocado por uma mística ou por uma luz. As pulsões seriam mais vulgares, estando ele sujeito, então, ao que o comum das pessoas está. O que de certa forma contraria essa máscara que ela põe no poeta - dando uma maior ambivalência ao poema - aparece por volta do centésimo verso, à p. 322, quando Sor Juana refere a vaidade e a competitividade que movem um poeta:

"No hay ciencia, arte, ni oficio, que con extraño vicio los poetas, con vana sutileza, no anden acomodando a la belleza; y pensando que pintan de los cielos, hacen unos retablos de sus duelos."

Precisamente a poeta que olha de soslaio para a presunção e para a cilada barrocas, como se fora isenta e humilde, porta-se como "censora” logo a seguir aos versos acima apontados, e aproveita para dizer que os censores sabem muito pouco e mesmo assim sentenciam. 
Já em quinto lugar, escolhemos um soneto ${ }^{97}$, de número 177 , em que o eu lírico procura muito comovido responder à frieza da mulher amada, utilizando argumentos relacionados ao impacto que a visão dela desencadeia:

"Mandas, Anarda, que sin llanto asista

A ver tus ojos; de lo cual sospecho

Que el ignorar la causa, es quien te ha hecho

Querer que emprenda yo tanta conquista.

Amor, señora, sin que me resista,

Que tiene en fuego el corazón deshecho,

Como hace hervir la sangre allá en el pecho,

Vaporiza en ardores por la vista.

Buscan luego mis ojos tu presencia

Que centro juzgan de su dulce encanto;

$Y$ cuando mi atención te reverencia,

Los visüales rayos, entretanto,

Como hallan en tu nieve resistencia,

Lo que salió vapor, se vuelve llanto".

Se o eu lírico se emociona face à visão do ser amado, é ainda assim ignorado o seu amor; se fosse diferente, não teria que atender a um pedido tão duro, isto é, um pedido tão duro sequer teria sido feito, caso o amor que ele sente fosse compreendido. Sublinhamos, para além da profundidade das emoções e da coragem que a confissão deixa perceber, a tentação que a visão do ser amado representa. Ver, que neste poema quer dizer acompanhar com os olhos, buscar, reverenciar tal senhora produz um efeito tão transformador (físico e imaterial ao mesmo tempo), que desfaz o coração de quem a aprecia, faz o sangue ferver e o vaporiza. E que seria isto de vaporizar o sangue? Perda do controle das próprias funções? Entrega absoluta das próprias forças nas mãos de outrem? Parece-nos ardor contra ardor, um que salta do objeto de desejo, pois a ele sempre pertenceu, outro que toma de assalto o corpo do sujeito que deseja.

${ }^{97}$ Ibid., pp. 293-294. 
É também interessante pontuar que os olhos que procuram esse objeto de desejo pensam, aliás fazem mais, julgam. E elegeram a senhora como razão maior para aquele arrebatamento ${ }^{98}$. Último processo descrito, o preciso momento da contemplação do ser amado gera mais uma mudança enternecedora e desvanecedora: os raios que permitem enxergar a beleza do outro, que permitem visualizá-lo, escorrem líquidos como pranto, atingidos pela indiferença do objeto de adoração. O amor, nessa roda, toma o corpo inteiro: afetos, intelecto, matéria envolvidos. Ele faz até um desenho, projeta-se de um corpo a outro, diluído em raios.

Pondo um fim à pequena lista de exemplos do exercício poético que Sor Juana consagrou ao olhar, verifiquemos nosso sexto texto, um fragmento de El sueño ${ }^{99}$ :

\author{
“A la región primera de su altura \\ (ínfima parte, digo, dividiendo \\ En tres su continuado cuerpo horrendo), \\ El rápido no pudo, el veloz vuelo \\ Del águia - que puntas hace al Cielo \\ $Y$ al Sol bebe los rayos pretendiendo \\ Entre sus luces colocar su nido- \\ Llegar; bien que esforzando
}

\footnotetext{
${ }^{98} \mathrm{O}$ fenómeno do arrebatamento, descontadas as diferenças, é referido por Santa Teresa, por Mariana Alcoforado e por Sor Juana Inés de la Cruz. Se é uma aspiração do ser humano, patente para um número limitado de artistas, tornada em discurso por um grupo ainda menor, é agora aludida para reforçar a possibilidade de um laço entre as três personagens. Da leitura de cada uma delas se depreende que se esforçaram por sentir o arrebatamento e deram a conhecer a emoção que ele proporciona.

${ }_{99}$ Ibid., p. 343-345. Achamos importante esclarecer os motivos pelos quais demos prioridade a esse fragmento. Trata-se da parte central do poema El sueño, quer ele seja encarado como um todo divisível em três partes, quer ele seja encarado como um todo divisível em cinco partes. A simetria, no caso de um poema como esse, é importante, estava entre os princípios norteadores de Sor Juana para confeccionar o poema, porque o poema fala, entre outras coisas, da própria noção de simetria. Se as tais partes forem, nesta ordem, o anoitecer, o dormir, o sonhar, o despertar e o amanhecer, nosso fragmento estará dentro do sonhar. Além disso, é das partes mais importantes (tem sido assim consideradas o anoitecer, o sonhar e o despertar), conforme os críticos. Por fim, enquanto as outras partes têm elementos que remetem à Astronomia, à Fisiologia, à Psicologia etc, o fragmento que escolhemos fica muito mais pelo domínio da intuição e do discurso, que podemos comentar com um pouco mais de familiaridade. O poema tem um sentido literal muito bonito, atrás do qual se organiza um sentido alegórico muito rico em intertextualidade, e que aponta para vários sentidos, o que se nos afigura bastante desafiador. Ficamos, então, com a tarefa de levantar os principais pontos de apenas um fragmento, escolhido em razão da relevância frente ao conjunto e do grau de dificuldade.
} 
Más que nunca el impulso, ya batiendo

Las dos plumadas velas, ya peinando

Con las garras el aire, ha pretendido,

Tejiendo de los átomos escalas,

Que su inmunidad rompan sus dos alas.

Las Pirámides dos - ostentaciones

De Menfis vano, y de la Arquitectura

último esmero, si ya no pendones

fijos, no tremolantes -, cuya altura

coronada de bárbaros trofeos

tumba y bandera fue a los Ptolomeos, que al viento, que a las nubes publicaba

(si ya también al Cielo no decía)

De su grande, su siempre vencedora

Ciudad - ya Cairo ahora -

Las que, porque a su copia enmudecía,

La Fama no cantaba

Gitanas glorias, Ménficas proezas,

Aun en el viento, aun en el Cielo impresas:

Estás - que en nivelada simetría

Su estatura crecía

Con tal diminución, con arte tanto,

Que (cuanto más al Cielo caminaba)

A la vista, que lince la miraba,

Entre los vientos se desparecía,

Sin permitir mirar la sutil punta

Que al primer Orbe finge que se junta,

Hasta que fatigada del espanto,

No descendida, sino despeñada

Se hallaba al pie de la espaciosa basa,

Tarde o mal recobrada

Del desvanecimiento

Que pena fue no escasa

Del visual alado atrevimiento -,

Cuyos cuerpos opacos

No al Sol opuestos, antes avenidos

Con sus luces, si no confederados

Con él (como, en efecto, confinantes),

Tan del todo bañados

De su resplandor eran, que - lucidos-

Nunca de calorosos caminantes

Al fatigado aliento, a los pies flacos,

Ofrecieron alfombra

Aun de pequeña, aun de señal de sombra: :

Estás, que glorias ya sean Gitanas,

O elaciones profanas,

Bárbaros jeroglíficos de ciego

Error, según el Griego

Ciego también, dulcíssimo Poeta

- si ya, por las que escribe 


\author{
Aquileyas proezas \\ O marciales de Ulises sutilezas, \\ La unión no lo recibe \\ De los Historiadores, o lo acepta \\ (cuando entre su catálogo lo cuente) \\ Que gloria más que número le aumente -, \\ De cuya dulce serie numerosa \\ Fuera más fácil cosa \\ Al temido Tonante \\ El rayo fulminante \\ Quitar, o la pesada \\ A Alcides clava herrada, \\ Que un hemistiquio solo \\ De los que le dictó propicio Apolo: : \\ Según de Homero, digo, la sentencia, \\ Las Pirámides fueron materiales \\ Tipos solos, señales exteriores \\ De las que, dimensiones interiores, \\ Especies son del alma intencionales: \\ Que como sube en piramidal punta \\ Al Cielo la ambiciosa llama ardiente, \\ Así la humana mente \\ Su figura trasunta, \\ Y la Causa Primera siempre aspira \\ - céntrico punto donde recta tira \\ La línea, si ya no circunferencia, \\ Que contiene, infinita, toda esencia -."
}

Embora não se saiba ao certo a data em que o poema foi escrito, é possível afirmar que foi publicado pela primeira vez no ano de 1692. "Nec spe, nec metu”, lema que também ajuda a entender o mundo barroco, terá estado na origem da criação de El sueño? O fragmento que escolhemos não contempla o princípio da jornada da alma, nem atinge o ponto do longo poema em que a frustração do eu lírico com o conhecimento (ou com a busca dele) é expressada. Mas podemos aludir a esses outros pontos, para tentar explicar melhor as imagens que vemos no fragmento que selecionamos. A partir da chegada da noite, momento de dispersão das vozes e morrer das luzes, vinha a sonolência e o sonho imperava; a alma sentia-se embevecida com a sua origem divina e com a hipótese de voar para alimentar o intelecto e vagava, mas não sem um projeto. 
Ia até as montanhas, avistava duas pirâmides e, castigada pela curiosidade, despencava. Persistia, conseguia ver a infinitude dos Cosmos e, feitos todos os raciocínios a respeito das formas, das funções, das simbologias, além da sucessão de estados de ânimo muito positivos, teria sua ambição de investigar a Natureza contraposta ao desengano, à ruína. O corpo de que ela se separara começava a voltar ao estado de vigília e a viagem que ela empreendera não havia se configurado em descobertas extasiantes, capazes de aplacar a sede de conhecimento. As cadeias do sonho se desatavam e o eu lírico não estava satisfeito com o resultado da aventura rumo ao conhecimento das essências. História resumida em prosa, evidentemente vazia de muitas imagens e da multiplicidade de referências eruditas, já nos permite localizar as específicas imagens do trecho que escolhemos. A noção visual de espaço (que no poema é nada mais nada menos do que o espaço sideral, espaço do voo da alma e dos pássaros) foi dada por Sor Juana por meio da alusão a uma altura, que o leitor devia poder calcular se visualizasse o todo dividido em três partes ${ }^{100}$. Estava também na medição das distâncias até aos astros, que tanta e tão auspiciosa revelação prometiam aos seus observadores, inclusive se lembrarmos que Sor Juana tinha genuíno interesse pelas ciências. Estava, ainda, no modo como a águia se movia, na paisagem incrível que contemplava e no desenho que as simetrias - análogas às outras simetrias, do espírito e das profundezas ofereciam $^{101}$. O poder das imagens também se pode medir, neste poema, ao

\footnotetext{
${ }^{100}$ Apoiada na idéia de que sempre haveria interlocutores no mundo por ela conhecido, Sor Juana, mesmo mergulhada num mar de referências difíceis de transmitir, dava referências ao leitor. Os conhecimentos que ela acumulara não devem tê-la afastado da vontade de dialogar. É possível que o tom do diálogo que ela propunha instilasse algum tipo de mal-estar nos homens porque, quando não se mostravam admirados com a erudição, o estilo, a perspicácia, passavam a um estado de indignação contra o discurso dela.

${ }^{101} \mathrm{O}$ romance de $\mathrm{n}^{\circ} 57$ (Obras completas de Sor Juana Inés de la Cruz, I, 2004, p. 168) tem mais ou menos a mesma discussão acerca da elevação simetricamente oposta à queda, que é o ser vencida, o estar às cegas. No romance, no entanto, o conflito que mexia com as culpas e com as penas do eu lírico decorria do amor a Deus e não da luta para viver no mundo do conhecimento.
} 
constatarmos quantas vezes e com que efeito Sor Juana falava em luzes e em sombras associadas, umas e outras, a forças naturais (como a força do raio e a da chama) e a limites (do descanso, alento). Isto sem contar que para além do poder ver, Sor Juana deu lugar à cegueira: talvez seja, afinal, tão frutífera quanto a visão, porque o poeta cego produziu muito e muito bem, sendo capaz de fazer ver as maravilhas que a olho nu são insondáveis, mas existem. Estaria disposta a admitir que conhecer e ver, neste caso, não davam direito a ser completa? Voltando ao "Nec spe, nec metu”, pode ser que não. A criação poética, nesse caso específico, pode ter revelado uma intuição bem aproveitada acerca dos limites do conhecimento. Sem medo de apontar a descoberta, ela escrevei, sem esperança de descobrir outra fortuna, ela acabaria cedendo a outro tipo de medo, mais físico até, chegando ao episódio da abjuração.

O texto poético não nascia da vivência dos escritores, os quais mantinham muita distância do seu produto, num procedimento oposto à busca de unidade entre autor e obra, por parte do artista do Romantismo - se quisermos um parâmetro para refletir sobre a individualização do autor. É claro que eram sensíveis aos ataques e às disputas, que as havia no período barroco. Sor Juana, por exemplo, parece ter respondido a uma provocação por meio de um poema, já que as suspeitas concernentes ao pai, Pedro Manuel de Asbaje y Vargas Machuca estavam nas entrelinhas de um discurso alheio (um poema, concretamente?). Pode ser que ela nunca tenha vivido sob a proteção do pai, pode ser que ele tenha abandonado a família quando ela era ainda muito nova, o que se conclui da leitura dos seguintes versos do epigrama de número 95 tem 
explicação nas suscetibilidades dela: "El no ser de padre honrado / fuera defecto, a mi ver / si como recibí el ser / de él, se lo hubiera yo dado»"102.

A escrita, resultado do esforço do poeta barroco, não podia ser compreendida apenas como testemunho pessoal, era antes reiteração de um modelo herdado pelo artista. Esse artífice da palavra documentava preceitos retóricos expressos em modelos circulantes (de retóricos clássicos, como Aristóteles, Isócrates, Cícero, Horácio, Quintiliano), o que significa que a aplicação de técnicas racionais e bem calculadas visava o alcance de efeitos. Portanto, o que devemos observar na produção poética do Barroco é o lugarcomum acrescido de preenchimento.

Sempre em nome da expressividade perdida nos poemas renascentistas, os poetas barrocos desejavam renovar a linguagem. Tratava-se de “arte combinatória de elementos coletivizados” ${ }^{103}$, como expôs João Adolfo Hansen. A novidade não encontrava lugar no trabalho do poeta do século XVII, pelo menos não no sentido com que aplicamos o conceito de novidade e de originalidade na poesia de épocas posteriores ao Barroco. O poeta não desejava (e nem o público queria) textos que desviassem dos exemplos reverenciados. $\mathrm{O}$ gosto e a fantasia já estavam regulados de antemão e dessa previsibilidade dependia o espaço ocupado pelo poeta no contexto dos agentes históricos em atividade naquele estilo. A imitação, ou emulação, era a norma geral da criação literária, por influência da referida tradição retórica que dominava a época. Copiar não era um processo inferior, mas uma "disciplina formadora”104.

\footnotetext{
102 Ibid., p. 230.

103 João Adolfo HANSEN, A sátira e o engenho, p. 16.

${ }^{104}$ Afrânio COUTINHO, A literatura no Brasil, p. 204.
} 
Para além de dar voz ao olhar, de uma maneira bastante codificada, o texto poético atendia exigências de outra ordem, ligadas por exemplo à seleção vocabular, à riqueza que podia advir do emprego de figuras de linguagem e também à exploração de temas mais ou menos amplos, mas explorados com profundidade.

“No campo lexical, a característica mais evidente da linguagem seiscentista é o horror às denominações correntes do objeto”, segundo Spina e Croll. Podemos recorrer à palavra "cristal", entre outras possíveis, para ilustrar o fato de os grandes autores manifestarem verdadeira obsessão quanto à exploração de determinados componentes de um poema. Procedendo ao reconhecimento da técnica, separamos fragmento de "Amado dueño mío"105, lira na qual Sor Juana emprega exatamente o vocábulo "cristal":

"Si ves el ciervo herido que baja por el monte acelerado, buscando, dolorido, alivio al mal en un arroyo helado, y sediento al cristal se precipita, no en el alivio, en el dolor me imita"

O eu lírico lamenta a distância que o separa de alguém denominado de Fábio e que parece estar alheio aos lamentos amorosos pois repousa na mansidão do campo (“Si del campo te agradas”). Pede que ele, se não quer ouvir, ao menos esteja atento aos sinais da natureza, que afinal são “ejemplos de mis males y mis bienes”. A enumeração que sucede este apelo leva de regato a rola, de rola a ramo e a flor e a penhasco, chegando ao cervo no trigésimo sétimo verso (escolhemos transcrever do verso trinta e sete ao quarenta e dois, tão

\footnotetext{
${ }^{105}$ Sor Juana Inés de la CRUZ, Obras completas de Sor Juana Inés de la Cruz, I, Lírica Personal, 2004, pp. 313-315.
} 
somente, para focalizar o vocábulo que apareceu como exemplo no texto teórico). Neste contexto, “cristal” é mais um elemento do panorama bucólico, é o cristal de gelo em que a água de um regato se transformou. E servirá para restituir as forças ao animal ferido.

As figuras de linguagem, como já afirmamos, igualmente constituíram recursos úteis e necessários ao poeta barroco, sem os quais ele considerava o seu produto árido e banal. Atento ao projeto de dispor o significado mais caro entre vários outros possíveis, esse poeta recorria a muitos artifícios, mergulhava na erudição, buscava "uma linguagem capaz de traduzir as

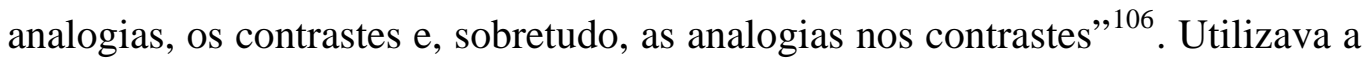
perífrase, a metonímia, a hipérbole, a paronomásia, a comparação, a aliteração, o eco, o jogo de palavras, a antítese, e com tais artifícios seduzia o leitor. Ao poeta cabia o domínio de uma linguagem cifrada que conseguisse estimular o leitor, provocá-lo de maneira que o fizesse sentir, tanto quanto o escritor, dono e merecedor de um diálogo que permitisse a sensação de dominar o mundo dos homens e o divino, aquele responsável por instituir o conhecimento.

Mais uma vez voltados para a produção poética de Sor Juana Inés de la Cruz, a escritora mais importante do século XVII em Nova Espanha, ressaltamos os versos "constante adoro a quien mi amor maltrata; /maltrato a quien mi amor busca constante"107, "bella ilusión por quien alegre muero, /dulce ficción por quien penosa vivo" ${ }^{108}$, os quais confirmam a recorrência a recursos expressivos.

\footnotetext{
${ }^{106}$ Francisco Maciel SILVEIRA, Lênia Márcia de Medeiros MONGELLI e Maria Helena Ribeiro da CUNHA, A literatura portuguesa em perspectiva, volume 2, p. 94.

${ }^{107}$ Sor Juana Inés de la CRUZ, Obras completas de Sor Juana Inés de la Cruz, I, Lírica Personal, 2004, p. 289.

${ }^{108}$ Ibid., p. 287.
} 
A adequação a todas essas imposições de caráter estilístico tinha a potencialidade de agradar os cidadãos cultos, para os quais a arte barroca era criada, estes exatamente mantidos pela distinção social que a arte, o jogo de palavras, a agudeza podiam oferecer. Cumpre lembrarmos que também o leitor era classificado como discreto ou vulgar, em conformidade com o que reconhecia na produção alheia.

Engenho é outra noção fundamental a respeito da natureza do Barroco. Diz-se engenhoso o poeta que desperta o leitor para a localização de conceitos, de imagens, de julgamentos não visíveis numa primeira mirada. É uma faculdade exigida do artista, pois confirma que ele tem uma percepção a funcionar de maneira ágil e incisiva. Restará que esse artista disponha de meios (os recursos estilísticos de que acabamos de tratar no presente capítulo) para enunciar o quanto foi sagaz ao inquirir a realidade à volta dele. Há de ver em profundidade e de remeter o leitor a algo mais do que as aparências.

Lembremos, também, a importância atribuída ao decoro e à prudência, nas diversas sociedades que cultivaram o estilo barroco ao longo do século XVII. A conduta decorosa e prudente era aconselhada para que o sujeito adquirisse respeito e admiração numa sociedade de corte. Artificialmente, ele deveria proceder com decoro e com prudência na avaliação das circunstâncias em que se envolvesse. A imagem valorosa que criasse para si o ajudaria a circular livremente entre os demais e a exibir-se no que diz respeito ao engenho. Se aparentasse decoro, prudência, discrição, era possível conquistar a permissão para maravilhar os outros com o engenho, com a agudeza.

Engenho, decoro, prudência, discrição e agudeza tinham sentido ético, mas também havemos de salientar o aspecto literário. 
"A literatura devia ter um caráter de purgação, de estímulo à virtude e à luta contra as más inclinações, unindo a busca da perfeição moral ao encantamento artístico, vale dizer, visava a ensinar deleitando". ${ }^{109}$

Para tratar da prosa cultivada durante o período barroco, passamos a destacar alguns procedimentos técnicos encontrados nas cinco cartas de Sóror Mariana Alcoforado. Levamos em consideração a separação proposta por Spina e Croll, o que nos leva a averiguar na produção da freira portuguesa: a escolha das palavras, a escolha das figuras, o equilíbrio ou ritmo e a forma do período. Em relação a esse último item do elenco dos estudiosos, havemos de observar o "stile coupé" e o estilo solto.

Notamos, em Mariana, termos tais como "desespero", "funesto", "alegria", "cruéis", "infeliz" e "agradáveis”110, todos resultantes de tradução do original francês, ligados à informação segundo a qual o Barroco prestava-se a representar estados de alma extremos e conflitantes.

Igualmente confirmamos o comentário de que predominaram as figuras de linguagem na literatura do período barroco, ao destacarmos o uso da hipérbole ("comprazia-me ao sentir que morria de amor", p. 17) e de antítese ("está em França no meio dos prazeres e nem por um momento pensa nas tuas dores", p. 15) na primeira carta.

Distinguimos o ritmo de uma carta do ritmo de outra, pois nos parece que a freira portuguesa oscilou, talvez de propósito. A primeira e a segunda cartas estão recheadas de exclamações e de interrogações e, portanto, obrigam a uma leitura mais fragmentada. A terceira carta tem um tom analítico, menos

\footnotetext{
${ }^{109}$ Afrânio COUTINHO, A literatura no Brasil. v. I, tomo 1, p. 225.

${ }^{110}$ Os três primeiros termos encontram-se à página 13 e os outros três, à 15 da edição de 1974 de Cartas portuguesas, utilizada neste trabalho e indicada em bibliografia.
} 
dramático (ela inclusive exige do amante atitude conotada como do sexo masculino: "Conjuro-te a que me dês este socorro, a fim de que vença a fraqueza do meu sexo", p. 47). A quarta vai um pouco além, oferece texto longo e lúcido ("Eu escrevo mais para mim do que para ti, e aquilo que procuro é consolar-me", p.75), assim como a quinta e última, bastante incisiva. Houve uma progressão no que toca a cadência das reflexões apresentadas; à medida que a autora se apropria de um modo de ler a situação vivida com o amante e aquela em que se encontra no momento da enunciação, apropria-se também de uma linguagem mais equilibrada, que suscita menos tensão.

O Barroco pode ser entendido como extravagante, no sentido de proporcionar ao leitor variedade, exemplo de erudição, exame de temas profundos e subjetivos e desejo de arrebatamento do leitor por meio da habilidade de quem escrevia. Mais do que discorrer sobre o texto barroco, neste ponto da tese esperamos contribuir para iluminar a riqueza e a representatividade do Barroco, em especial o da cultura hispânica e o português. Por isso, e atendendo mesmo às metas do presente capítulo, cumpre ainda e tão somente fornecermos dados para pensar os temas mais caros aos artistas do seiscentos. Em síntese podemos afirmar que os textos barrocos versavam sobre "a vida, o homem e a passagem do tempo"111. Isso significa dizer que:

“ (...) poetas e prosadores preocupavam-se com a eternidade e com o infinito, porque havia na atenção às relações temporais e às espaciais um profundo temor da morte aliado a uma preferência pelos aspectos cruéis, dolorosos, espantosos, terríveis, sangrentos, repugnantes" 112 .

\footnotetext{
${ }^{111}$ Helmut HATZFELD, Estudos sobre o Barroco, p. 78.

${ }^{112}$ Fidelino de FIGUEIREDO, História literária de Portugal (séculos XII-XX), p. 222.
} 
Como forma de apreender a morte, os escritores mostravam mutações, dúvidas, disfarces, inconstância, instabilidade. A noção de movimento era importante, lembrava a adaptabilidade de que estivemos a falar no início do capítulo, a propósito das modificações na moral política da época.

Finalmente, é mais trabalhoso encaixar nesse quadro um último motivo de muita relevância e complexidade: a sensualidade, outrora apresentada da seguinte maneira:

"Tanto na lírica quanto na mística, existe essa sensualização de assuntos religiosos, embora muita vez dissimulada sob toda casta de disfarces ou artifícios retóricos e estilísticos, distorções ou obscuridades, tão do gosto da época" ${ }^{113}$.

O que cumpre salientar a esse respeito, sem a pretensão de planificar o que é controverso, é que a sensualidade e o erotismo eram marcas, sinais de um corpo e de uma estrutura mais ampla, a social, capazes de comunicar o que era existir na hierarquia, o quer era ser de tipo elevado. Caso o eu lírico masculino descrevesse uma figura feminina como sedutora, equivalia a declarar ao leitor do poema que ela era digna de distinção, que culturalmente aquele atributo a destacava. A sensualidade e o erotismo davam conta de um código social que desnudava a organização característica das sociedades barrocas e por isso eles eram temas freqüentes nos poemas e nas cartas, gêneros que a esta tese mais interessam.

Fidelino de Figueiredo justificou o êxito das Cartas portuguesas com dois ou três argumentos rapidamente apresentados e entre eles está o fato de elas

${ }^{113}$ Ibid., p. 222. 
"oferecerem uma flagrante análise da paixão amorosa"114 que sabemos fruto da sensualidade que Mariana, a autora, vê e enuncia no porte, no movimento, no garbo daquele que a encantou e que, precisamente por ser descrito como sensual e erótico, é também hierarquicamente elevado, poderoso, respeitável. Ao privilegiar esses traços do personagem descrito em suas cinco cartas de amor, Sóror Mariana Alcoforado fala de outras virtudes, assim codificadas; ela informa-nos sobre a posição social dele e sobre o direito que ele possui.

Em se tratando de um estudo de gênero como este, e de acordo com o que ficou estabelecido na introdução e no capítulo II, "Duas mulheres em dois panoramas da sexualidade", vale a pena registrarmos a postura orgulhosa e autoreferencial com que ela reivindica atenção e direitos. Ainda que a disciplina monástica tolerasse certos costumes, não os pretendia sancionar, o que nos permite, por fim, falar em Mariana como de quem alargou os limites barrocos.

Quanto a Sor Juana Inés de la Cruz, por ora é suficiente encerrar o tópico com o que Camila Henríquez Ureña escreveu ${ }^{115}$ :

"Parte de su poesía sigue el formalismo en boga dentro de su época y su medio; pero la expresión genuina de su feminidad hay que buscarla en los claros versos de sus villancicos, en la fina ironía de sus redondillas, y sobre todo en sus versos de amor profano. No solamente son "los más suaves y delicados que han salido de pluma de mujer", sino los primeros en nuestro idioma, los que abren el camino a la expresión del amor humano en nuestra poesía femenina”.

Em atenção ao que ela observou, salientamos três poemas, a endecha de $n^{0} 78$ e os sonetos de $n^{\circ} 147$ e 164 . O primeiro poema tem nos versos iniciais o espírito e a expressão que Camila Henríquez Ureña destacou da produção

\footnotetext{
${ }^{114}$ Ibid., p. 288.

${ }^{115}$ Camila Henríquez UREÑA, Obras y apuntes, 2006, p. 136.
} 
poética de Sor Juana, mas não os mantém: “Agora que conmigo / sola en este retrete / por pena, o por alivio, / permite Amor que quede; / agora, pues, que hurtada / estoy, un rato breve, / de la atención de tantos / ojos impertinentes, / salgan del pecho, salgan / en lágrimas ardientes, / las represadas penas...”116 . O eu lírico pedia a passividade da solidão, mas com ela viria o choro que, como o fragmento esclarece, era de explosão e não de mergulho em si. O eu lírico, com mais feminilidade no começo, pedia a passividade, mas cedia à convulsão, pois o marido perdido era sua alma. No soneto 147 , temos a contemplação, o cuidadoso e penetrante exame de um símbolo; entendido como exercício de contemplação, parece-nos mais condizente com a aceitação, com a feminilidade: "Rosa divina que en gentil cultura / eres, com tu fragante sutileza, / magisterio purpúreo en la belleza, / enseñanza nevada a la hermosura” (p. 278). O soneto 164, pela dedicação e pelo processo que ela desencadeava, também faz ver traços de uma feminilidade: "Esta tarde, mi bien, cuando te hablaba, / como en tu rostro y tus acciones vía / que con palabras no te persuadía, / que el corazón me vieses deseaba. / y Amor, que mis intentos ayudaba, / venció lo que imposible parecía: / pues entre el llanto, que el dolor vertía, / el corazón deshecho destilaba” (p. 287).

\section{A clausura feminina: liberdade vigiada}

A ideologia barroca estava apoiada na Contra-Reforma católica, que procurava reencontrar alguns ideais da civilização medieval. O momento apontava, entre outras coisas, para o resgate da vida rude e austera nos conventos, masculinos e femininos, com a diferença de que nos masculinos ganharia força a tendência à rigidez e ao ascetismo, ao passo que nos femininos

\footnotetext{
${ }^{116}$ Sor Juana Inés de la CRUZ, Obras completas de Sor Juana Inés de la Cruz, I, 2004, p. 204.
} 
haveria forças de resistência, no sentido de manter ainda alguma separação entre locais permissivos quanto à comodidade e às visitas e locais reservados exclusivamente à contemplação e aos rituais de cunho religioso ${ }^{117}$.

Foram basicamente dois os modelos de conduta forjados para fazer frente a essa nova orientação; o modelo espanhol, aplicado na Europa e no Novo Mundo, caracterizava-se pela severidade (orações em horários muito controlados, nenhum contato físico com as pessoas de fora dos muros dos conventos, leituras edificantes, imobilidade do corpo durante a meditação, silêncio total); o modelo francês era um pouco mais maleável.

Com a passagem do tempo, vingaria o modelo espanhol, o que nos ajuda ao mesmo tempo a defender a hipótese de Sóror Mariana Alcoforado se ter envolvido com um militar estrangeiro - e principalmente a hipótese de o caso ter sido abafado pela Igreja e pela família - e a compreender a pressão exercida sobre Sor Juana Inés de la Cruz a partir de 1691.

Podemos recorrer às palavras de Isabel Morujão, para reconstruirmos com brevidade o panorama dos conventos portugueses do século XVII: “De qualquer modo, o progresso na vida espiritual e a determinação de evoluir e progredir no amor de Deus não deixa de caracterizar o quadro da vida monástica portuguesa, ainda que esta seja marcada por sofridos processos de escrúpulos, desconfianças e inimizades”"118. Vale recordarmos, também, que a experiência

\footnotetext{
117 Rosario VILLARI (org.), O homem barroco, 1995. Mario ROSA, autor do capítulo VIII, “A religiosa”, contou à p. 177 que havia até mulheres solteiras hospedadas provisoriamente nos conventos femininos; além disso, relatou também a ocorrência de tortura psicológica que efetivamente levava as freiras à loucura e que era conseguida por meio de leituras e da atividade de pregadores e confessores. Por volta da metade do século XVII, houve segundo Rosa uma quantidade enorme de casos de perturbações mentais, interpretadas como possessões diabólicas. As freiras assustavam-se com o que lhes era ensinado e adoeciam de medo.

${ }^{118}$ Isabel MORUJÃO, "Poesia e santidade, alguns contributos para uma percepção do conceito de santidade, a partir de duas biografias devotas de religiosas do século XVII português", Via Spiritus, 3, 1996, pp. 235-261.
} 
no seio das Carmelitas Descalças, em 1667, já assustara Sor Juana, em razão da austeridade nessa ordem. E mesmo tendo saído daquele ambiente e ido para a Ordem de São Jerônimo, acontecimentos paralelos (eclipse, inundações, pragas), que nada tinham com a vida religiosa e literária de Sor Juana, interferiram na maneira como ela assimilaria a coerção praticada pelos censores, tais como o arcebispo e o antigo confessor ${ }^{119}$. Para além de obrigar a muito trabalho manual para afugentar o ócio, flagelações (que Paz refere à p. 172, ao lado do gosto pela confecção de doces, quem sabe numa tentativa de mostrar a ambivalência daquele meio) e penitências decorrentes de delações, o rigor do sistema novohispano estava patente na forma ameaçadora com que os diretores espirituais acompanhavam as atividades literárias da religiosa; havia quem se sentisse envaidecido com os textos que ela dedicava e havia quem os invejasse e julgasse inadequados a uma monja e a uma mulher. Como deve ter havido, também, quem questionasse a ostentação das religiosas em geral, pois elas possuíam bens materiais e até jóias.

E os reflexos da transgressão de Mariana Alcoforado - se alguma transgressão houve concretamente -, como podem ser avaliados, tendo em conta esse contexto barroco de recrudescimento da disciplina individual e das normas que regiam o uso do espaço comunitário?

\footnotetext{
${ }^{119}$ Se até a sucessão de calamidades naturais e políticas Sor Juana fora paciente, preocupada com os pobres, obediente quanto convinha a ela mesma e estudante incansável, a atmosfera de medo conseguiu transtorná-la. Houve um eclipse do Sol em 1691 e em seguida sa culturas do milho e a do trigo saíram arrasadas por causa de um fungo, do que resultou, enfim, uma crise mais ampla na economia agrícola e escassez de alimentos. A saída encontrada e sustentada por mais de um ano pelos dirigentes foi apelar ao divino e controlar as provisões no mercado abastecedor, o que deve ter afligido e irritado ainda mais a população. Houve aglomerações, motins, um incêndio e, por interferência de um religioso, o povo se acalmou no momento mais tenso e foi possível inclusive preservar papéis guardados no palácio onde vivia o vice-rei. À p. 574 de Sor Juana Inés de la Cruz o las trampas de la fe, Paz concluiu o relato que pautou nossa recapitulação desses acontecimentos: "De este modo un acontecimiento público que nadie había previsto cambió radicalmente y para siempre la vida privada de Juana Inés”, aludindo ao fato de que Sor Juana ficaria tão impressionada quanto os índios e o povo em geral, agravando-se, assim, o conflito de idéias que se tornara evidente na Carta atenagórica.
} 
Em primeiro lugar, apontemos o seguinte: o Real Mosteiro de Nossa Senhora da Conceição, morada de Mariana Alcoforado até o ano de sua morte, sempre teve privilégios e tinha já uma história longa, pois fora criado em 1467. Os privilégios eram garantidos pelas relações com Roma e pelos vínculos com a aristocracia portuguesa local, isto é, a aristocracia da região de Beja. Quando fazia pedidos ou ao clero ou ao rei, o mosteiro era geralmente atendido, conforme atestam documentos oficiais. Um documento de 1646, relativo à situação de 1628, mostrava que o convento da Conceição de Beja, onde vivia Mariana Alcoforado, tinha duzentas e onze mulheres num espaço relativamente pequeno, o que, na visão que as religiosas traziam de casa, deve ter legitimado, por exemplo, a existência de pequenas casas apartadas do edifício principal, construídas pelas famílias das religiosas outrora mais abastadas ${ }^{120}$.

No que diz respeito ao ambiente, é preciso verificar que “o ambiente de devoção e fé não era edificante, porque as coisas do tempo sobrepunham-se às coisas do espírito"121. Mais relevante era ter posses e protetores para estar à vontade naquele espaço, pois assim haviam sido educadas as religiosas que “(...) provinham frequentemente de classes abastadas”122. A orientação mandava acolher os familiares das freiras, pois exerciam influência em situações que o convento carecia de apoio externo. Como exemplo da "autogestão", podemos aludir às professas e às noviças que conseguiam escolher o confessor, ato proibido nos conventos em geral, mas que se obtinha ali mediante troca de favores.

\footnotetext{
${ }^{120}$ Luciano CORDEIRO, Soror Mariana, 1890, p. 181.

${ }^{121}$ Alfredo SARAMAGO, Convento de Soror Mariana Alcoforado, p. 82.

122 João PALMA-FERREIRA, Antónia Margarida de Castelo Branco. Autobiografia, 1984, p. 32.
} 
Mais determinante do que a agudização do controle sobre as religiosas foi o aumento de poder da aristocracia mencionada linhas acima; como ela estava mais ativa, importava menos a vontade da Igreja. Somemos ao exposto a questão financeira interna: o convento era muito rico e, à época de Mariana Alcoforado, havia freiras suficientes para pagar dotes no ingresso. Nada faltava no dia-a-dia, ao contrário, comiam muita carne, bebiam muito leite, recebiam regularmente hortaliças, faziam doces e desfrutavam do requinte de poder escolher a dieta que mais lhes agradasse. As criadas ali moravam para poder servir a qualquer hora ("houve alturas em que havia mais criadas no convento do que freiras”, p. 126 de Convento de Soror Mariana Alcoforado) e funcionavam como ligação com o mundo exterior.

O que realmente temos a estranhar daquilo que se atribui a Mariana? Era mesmo impossível que uma religiosa jovem e de boa educação ${ }^{123}$, nesse meio que acaba de ser descrito, tivesse um amante e permanecesse na clausura depois da descoberta do caso amoroso? A eleição para porteira seria improvável, tendo ela estado em desacordo com as normas de castidade e de isolamento? Neste ponto recorremos à informação segundo a qual ela teria sido eleita no ano de 1668, mesmo ano em que a abadessa era Brites Freire, talvez a confidente referida mais de uma vez nas cartas. A incumbência viria a coincidir com a necessidade pessoal de reerguimento, pois o afastamento de Noel era sabido.

Ainda que houvesse os freiráticos nos conventos portugueses (e também nos novo-hispanos, conforme Paz informou à p. 171 de Sor Juana Inés

\footnotetext{
${ }^{123}$ Voltamos a este dado, já explorado no capítulo I, na expectativa de clarificar e reforçar idéias: se o Barroco ficou marcado como período de muita erudição, Mariana Alcoforado pode não ter sido excecção, na medida em que consta que educara a irmã Peregrina desde muito cedo, tendo a mãe falecido, e essa irmã depois viria a ser eleita escrivã e abadessa, tarefas que pressupuham bons conhecimentos de gramática e boa letra.
} 
de la Cruz o las trampas de la fe), Mariana passou a configurar-se em referência nos salões franceses. A forma pouco discreta e pouco prudente com que ela discutira o desejo de ser amada por um oficial francês e de abandonar a clausura teria ultrapassado a extravagância do comportamento dos nobres - que regularmente visitavam suas preferidas no recolhimento das celas dos conventos femininos? Haveria assim tanta demanda por discurso amoroso e discurso erótico? O exposto no capítulo II faz crer que sim, concorrendo as duas explicações para o entendimento da época e do fenômeno literário. Voltando à questão dos freiráticos, que ilustra um aspecto da natureza das mudanças nos conventos femininos, eram esses tipos já objeto de sátira no próprio século XVII, conforme atesta o poema a seguir ${ }^{124}$ :

Minhas lindas freiras

Lá desse convento, Que andais como loucas, Vadiando extremos.

Recebi de vós Uns galantes versos Que por serem vossos Vinham mui travessos.

Quem vos obrigou, Ou que punhal fero Vos moveu tão duro, Para tanto excesso?

A falta de amantes Sem dúvida creio Fazem tais prodígios Com tão grandes erros

$$
\text { (...) }
$$

Já ninguém vos ama, Fogem deste erro, Porque amar a freiras É só para os néscios.

$$
(\ldots) \text { ” }
$$

${ }^{124}$ Ana MIRANDA, Que seja em segredo, 1998, pp. 92-93. 
É relevante, então, a desobediência de Mariana?

Parece-nos que a freira portuguesa merece, afinal, destaque pelo fato de ter transcendido a moral de uma regra de convivência social, segundo a qual era imperativo fazer-se discreta, prudente. A iniciativa da publicação das cartas partiu de Claude Barbin, supostamente aliado ao próprio Chamilly, mas, mesmo assim, ela se arriscou, expôs-se diante daqueles que formavam o círculo dela. Irmãs, família e amigos dos parentes (o irmão certa vez teria confiado a um amigo a correspondência de Mariana) saberiam da ligação amorosa dela com um estrangeiro de passagem por Portugal, estariam a par da transgressão realizada por ela, pois freiras eram objetos de desejo, deveriam por isso aguardar o convite e a visita de seus pretendentes, apelidados de freiráticos. E Mariana agiu de outra maneira, mais pessoal e mais corajosa.

Também Sor Juana Inés de la Cruz, quando alimentou o jogo de Manuel Fernández de Santa Cruz, o bispo de Puebla, estava a romper uma convenção, uma etiqueta, pois podia muito bem ver-se privada da consentida liberdade de sair da cela, de receber presentes, de estudar etc. E realmente teve de enfrentar a proibição.

Finalmente, outra forma de compreender os horizontes das religiosas, nos dois locais estudados, é examinar a interessante questão dos modelos literários utilizados durante a vigência do Barroco, já referidos no capítulo I, por ocasião das leituras de Sóror Mariana Alcoforado e Sor Juana Inés de la Cruz. O tema volta a ser discutido porque, no capítulo I, apresentamos um levantamento das potenciais leituras e de alguns traços concretos que sugeriam influências sofridas pelas religiosas; agora, podemos apontar textos que nasceram do trabalho partilhado por escritoras portuguesas e escritoras novo-hispanas do 
século XVII. Esses textos eram enviados da Nova-Espanha para Portugal ${ }^{125}$, fomentava-se a familiaridade do novo-hispano com a língua portuguesa e do português com a língua espanhola, pois era patente o desejo de compreender e de pôr em prática o exemplo de habilidade e de liberdade encontrado no outro.

O Barroco novo-hispano encantava as freiras portuguesas da Casa del Placer $^{126}$ por causa da técnica que depreendiam dos textos em espanhol e, assim, nascia a vontade de aproximação e de aprendizagem; a expressão da identidade e da liberdade das freiras portuguesas provocava a curiosidade de uma novo-hispana e estava por conseguinte inaugurado o diálogo entre elas, pois fora promovida a identificação ${ }^{127}$.

Apoiadas por membros da nobreza (basta aludir ao papel da Condessa de Paredes na condução dos textos até Lisboa), elas encaminhavam enigmas, dos quais expomos alguns exemplos: 1) “¿Quál es aquella homicida /que, piadosamente ingrata, /siempre em quanto vive mata /y muere quando da vida?”; 2) “¿Quál será aquella aflicción /que es, com igual tiranía, /el callarla cobardía, /dezirla desatención?”; 3) “¿Quál puede ser el dolor /de efecto tan desigual /que, siendo en sí el mayor mal, remedia outro mal mayor?”; 4) “¿Quál es la Sirena atroz / que em dulces ecos velozes / muestra el seguro em sus vozes, /guarda el peligro en su voz?”; 5) “¿Quál es aquella deidad /que con tan ciega

\footnotetext{
${ }^{125}$ A pertinência da alusão ao tráfego de textos literários no período barroco é reforçada, se mencionamos que também Itália e Espanha estavam envolvidas nesta rede. Temos conhecimento de que as academias, alicerçadas nas noções de erudição, de jogo e de cooperação, lançavam problemas a serem respondidos por ilustres como o Padre Antonio Vieira. O resultado da proposição saía numa determinada língua e logo depois era traduzido, em face do interesse que essas contendas despertavam.

${ }^{126}$ Em artigo para a revista Via Atlântica, "Sobre os enigmas de Sóror Juana Inés de la Cruz encontrados em Lisboa, ou de como o México, pouco a pouco, mas inexoravelmente, aproxima-se de Portugal, e viceversa", (4), 2000, Horácio Costa apresenta a agremiação de freiras portuguesas que cultivavam a produção de poemas mundanos, do prazer, num exemplo da peculiaridade que possuíam as religiosas portuguesas, ao mesmo tempo submissas à Igreja e movidas por desejos pessoais.

${ }^{127}$ Fator de identificação entre as freiras portuguesas e novo-hispanas, à partida, era o próprio regime conventual em que viviam, conforme já ficou demonstrado neste mesmo capítulo. Portanto, com curiosidades semelhantes, com rotinas calculadas de maneira similar, aproveitaram do trânsito que as ordens religiosas facilitavam e trocaram textos literários.
} 
ambición, /cautivando la razón, /toda se haze libertad?”; 6) “¿Quál puede ser el cuidado /que, libremente imperioso, /se haze a sí mismo dichoso /y a sí mismo desdichado?”; 7) “¿Quál será aquella passión /que no merece piedad, /pues peligra en necedad /por ser toda obstinación?”; 8) “¿Quál puede ser el contento /que, con hipócrita acción, /por sendas de recreación /va caminando al tormento?”; 9) “¿Quál será la idolatría /de tan alta potestad /que haze el ruego indignidad, /la esperança grosería?”.

Não havia condenações nem mal-estares por parte das religiosas portuguesas contra Sor Juana, porque não a consideravam uma estrangeira a ousar escrever melhor do que um renomado português ${ }^{128}$. O fenômeno da correspondência, afinal, parece-nos privilegiado pela atmosfera de valorização do conhecimento e pela ânsia - neste caso, feminina - de superar a rigidez da ordem social estabelecida durante o Barroco.

Foi possivelmente a curiosidade intelectual dominante em Sor Juana Inés de la Cruz a energia motriz responsável por promover o conhecimento ao pormenor do conjunto das práticas discursivas do Barroco. Nos poemas que ela escreveu, é pacífico para os estudiosos notar não só uma sofisticada aplicação desses conceitos, como também o gosto barroco. Contudo, a exuberância, a complexidade de tais poemas pode ser mais instigante para o leitor do que a aplaudida utilização das convenções e do que esta ou aquela predileção

\footnotetext{
${ }^{128}$ Antonio ALATORRE, Sor Juana Inés de la Cruz. Enigmas ofrecidos a la Casa del Placer, 1994. À p. 57 é dada a informação de que a religiosa novo-hispana não foi tomada como intrusa, quando propôs interpretação diferente da que o Padre Antonio Vieira encontrou para as finezas de Cristo. À p. 58, o organizador prossegue nos esclarecimentos, dizendo que uma portuguesa também contestou Vieira, na perspectiva de se tratar de um debate de idéias muito lucrativo: “Así como Sor Juana criticó el sermón del Mandato, así una monja portuguesa, no sé si antes o despues, criticó otro sermón de Vieira, el llamado “de la Sementera” (sermão da Sementeira)". Alfonso JUNCO, “António Vieira en México”, capítulo de Sor Juana Inés de la Cruz e o Padre António Vieira ou a disputa sobre as finezas de Jesus Cristo, 1998, pp. 139-153, afirma que Sor Margarita Ignacia, no ano de 1753, em Lisboa, havia defendido Vieira do ataque de Sor Juana.
} 
característica da época.

Esse aspecto do acervo de Sor Juana tem colocado em xeque as interpretações dos estudiosos: já houve quem enxergasse nos versos dela vagos resquícios de um amor não correspondido; houve quem julgasse descortinar a melancolia ocasionada por um impedimento de ordem financeira para a concretização de um casamento; houve quem apontasse um indício de homossexualismo etc. Terá o pesquisador, em muitos casos, projetado as próprias expectativas de leitura, os próprios “apetites” no diálogo com os textos? Nem sempre a luz que um pesquisador lança sobre a obra de Sor Juana nos ajuda a ir além de uma idéia fria. Isto é facultado pensar a quem consulta a obra de Octavio Paz, referida diversas vezes referida nesta tese. Com Sor Juana Inés de la Cruz o las trampas de la fe podemos formar opinião mais balizada, a partir de uma longa fortuna crítica, tomando o cuidado para não incorrer no exagero de assumir as interpretações de Paz como definitivas e nunca.

Enfim, existe muito mais trabalho para além do que se vê no famoso soneto $145^{129}$, "Éste, que ves, engaño colorido, /que del arte ostentando los primores, /con falsos silogismos de colores /es cauteloso engano del sentido...”, que mantém diálogo intertextual com poema do espanhol Luís de Gôngora (1561-1627). O décimo verso de Sor Juana contém a metáfora da flor (“es una flor ao viento delicada”) que, aliás, é vista também em Gregório de Matos (1663-1696): “Penha a nau, ferro a planta, tarde a rosa?”, contemporâneo de Sor Juana. Com a metalinguagem, ela falava da arte e daquilo que os observadores queriam fazer da artista, distorcendo-a. Via-se num espelho e recusava a própria imagem, por ser enganosa.

\footnotetext{
${ }^{129}$ Octavio PAZ, Sor Juana Inés de la Cruz o las trampas de la fe, 2003, p. 277.
} 
Sob o aspecto da luta pela aquisição da visibilidade feminina, podemos afirmar que Sor Juana percebia, entre outras coisas, que a privacidade fazia falta à mulher. Talvez por isso se tenha mantido num convento cujas celas eram semelhantes a apartamentos e servidas por diversas empregadas - no Convento de São Jerônimo ela tinha cerca de dezessete serviçais. Ela notou, igualmente, que era indispensável cultivar boas relações com os nobres, dedicarlhes poemas ${ }^{130}$ e freqüentar as suas reuniões, para desfrutar de proteção material e moral. Algumas de suas obras mais significativas, inclusive, foram publicadas devido ao empenho de figuras ilustres, como a condessa de Paredes, Maria Luisa de Lara y Gonzaga. A peça $O$ divino Narciso nasceu assim. Por outro lado, é preciso reconhecer que entre nobres Sor Juana estava à vontade com o papel que desempenhava, quer dizer, se nunca tivera vocação religiosa, estar entre eles devia ser mais recompensador do que estar entre monjas, por exemplo, pois agia de acordo com sua cultura, tinha possibilidade de interlocução, era instigada para escrever mais e melhor. O convívio não lhe seria estranho nem desagradável.

\footnotetext{
130 Podemos apontar o romance 13, o 15 e o 16, todos dedicados ao “Señor Marqués de la Laguna”; e também o 20 e o 21, escritos para a Condessa de Paredes. Encontram-se respectivamente em: pp. 40-42, pp. 45-48, pp. 48-50, pp. 59-60 e pp. 61-65 da obra acima referida.
} 


\section{CaP. IV - A Paixão que Subsiste nas Cartas}

"Na sua gênese e na sua realização, a literatura aponta sempre para o que falta, no mundo e em nós"

Leyla Perrone-Moisés

O capítulo concentra teoria e análise textual das cinco cartas presentes na obra Cartas portuguesas, da Carta atenagórica e da Respuesta a Sor Filotea e de "La Carta", além de colocá-las em um contexto, de forma a permitir que o leitor as compreenda, perspectivando também o impacto causado por elas.

Salientamos que a totalidade da obra de Juana Inés de la Cruz excede em quantidade, e muito, a totalidade da obra de Mariana Alcoforado. Foi preciso, então, proceder a um recorte muito grande da obra de Sor Juana em nome de uma opção compatível com as cinco cartas de Sóror Mariana. Realizar a exegese de toda a obra da religiosa novo-hispana significaria passar em revista minuciosa o equivalente a quatro volumes de mais ou menos seiscentas e sessenta páginas cada, sem considerar a produção para a música. Sendo assim, dela escolhemos três cartas, a Carta atenagórica, a Respuesta a Sor Filotea e La carta; ambas se encontram no volume IV, publicado pelo Fondo de Cultura Económica do México ${ }^{131}$. No capítulo anterior já apresentamos a leitura de alguns poemas. ${ }^{132}$

\footnotetext{
${ }^{131}$ Sor Juana Inés de la Cruz, Obras completas de Sor Juana Inés de la Cruz I. Lírica Personal e IV. Comedias, Sainetes y Prosa, 2004.

${ }^{132}$ Escolhemos, por causa da importância das imagens: um romance, uma endecha, uma décima, dois sonetos (dois completos e mais alguns versos de outro), alguns versos de uma silva (o famoso El sueño), uma lira e parte de um ovillejo. Foram todos extraídos do volume I. Por causa da feminilidade, passamos mais brevemente por outros três poemas, a endecha 78 e os sonetos 147 e 164.
} 
Comecemos pelas cartas em geral, pois elas possibilitam a comparação entre as duas artistas.

A prática da escrita ficcional e de cariz pessoal provoca o investigador das Letras, desafia-o e ele então admira, tal qual voyeur, mas principalmente se articula. Por vezes se sente impelido a dialogar com o passado e a interpelar seus atores, tão familiarmente, como se entabulasse conversa com interlocutores do seu meio, (des)orientados pelos mesmos estímulos, ávidos de respostas tanto quanto ele.

Sendo esta dinâmica reatora uma parte da verdade que explica a curiosidade intelectual, a questão “por que escrever cartas?” tem coerência, quando proferida por quem estuda de maneira disciplinada o conjunto da obra e a biografia de um escritor dedicado, também, às confissões, ao aconselhamento, ao estreitamento de vínculos, ao relato informativo etc que as cartas são.

Ainda que assim seja, circunscrevamos melhor a premissa deste exercício de interlocução: no âmbito de uma pesquisa como a que ora se apresenta, acerca da cultura letrada barroca, podemos compreender a indagação referida e partir dela, sem o risco de ser falaciosa nossa proposição. A introdução preparada por João Adolfo Hansen para a obra Cartas do Brasil nos faz descobrir, entre outras características, que o ritmo de escrita de uma carta no século XVII era dado pelas pausas necessárias para o aparar da pluma com que se preenchia o papel à tinta; havia entre os barrocos o hábito de ditar cartas; criálas consoante a agudeza, o decoro, a prudência exigidos dos escolhidos daquela 
época era um ato de reforço da hierarquia ${ }^{100}$. Portanto, as motivações da produção de cartas passavam pelas convenções sociais e transitavam a esfera das habilidades literárias. Não se tomava parte nesta atividade inocentemente nem era ela aleatória.

Mesmo constatada a pertinência da pergunta "por que escrever cartas?” relativamente a uma fase da história da humanidade, é correto ampliar o campo de visão para assumir a troca de correspondência como atividade importante em qualquer tempo. O reconhecimento da relevância da epistolografia legitima o uso das cartas neste percurso investigativo. Como bem definiu Ernesto Manuel de Melo e Castro, poeta português:

“Escrever cartas é assim um pequeno ofício 'literário' no sentido mais restritivo e convencional desse termo, pois ao escrever uma carta não se pode fugir a um código que modela e altera o que tão simplesmente queremos e gostaríamos de dizer. Faz-se literatura sem o querer"133.

Analisar cartas é confiar na especificidade desta linguagem, é ter avançado uns passos em direção ao texto literário, que exige do escritor mais domínio, mais recursos, mais revisão.

A pergunta “por que escrever cartas?” pode ser proposta ao missivista do mundo antigo, caberia fazê-la ao homem medieval, estaria justificada caso fosse dirigida aos cidadãos das sociedades modernas, não perderia o sentido para o sujeito da contemporaneidade, uma vez que a correspondência, sobretudo a pessoal, tem força inconteste. Na Antiguidade,

\footnotetext{
${ }^{100}$ Em João Adolfo HANSEN (org.), Cartas do Brasil, 2003, encontramos também: “O ponto de vista do remetente é o de uma liberdade de aplicação de preceitos técnicos situada, em cada gênero de carta, no intervalo limitado pela inépcia e pela licença poética” (p. 21).

${ }^{133}$ Walnice Nogueira GALVÃO e Nádia Battella GOTLIB (orgs.), Prezado senhor, prezada senhora, 2000, p. 15.
} 
Marco Túlio Cícero (106a.C. - 43a.C.) postulou em forma de cartas; Quinto Horácio Flaco (65 - 8a.C.) preocupou-se com o tema; Lúcio Aneu Sêneca (4a.C. - 65d.C.) escreveu cartas e tratados sobre cartas. Durante a Idade Média, entre outros humanistas, foram Francesco Petrarca (1304-1374), Juan Luís Vives (1492-1540) e Erasmo de Rotterdam (1466-1536) aqueles que redigiram cartas notáveis, tomadas como modelos. Atentos ao universo das escritoras que motivaram e motivam esta tese, ambas religiosas, ressaltamos que muitos místicos, quase todos da Idade Moderna (excetuados São Francisco de Assis, que viveu entre os anos de 1181 e 1226, e Santa Clara de Assis, figura da Idade Média cujo período de vida estendeu-se de 1193 a 1253), tais como São Francisco Xavier (1506-1552), Santa Teresa de Ávila (1515-1582), São João da Cruz (1542-1591) e Frei António das Chagas (1631-1682) escreveram cartas. Em Portugal, lembramos a obra de D. Francisco Manuel de Melo (1608-1666), Carta de guia de $\operatorname{casados}^{134}$, bem estudada por Edgar Prestage.

Neste preâmbulo traremos à luz uma breve apreciação dos significados sociais atribuídos à escrita das missivas. Entretanto, se havemos de pôr o espírito crítico a funcionar desde algum ponto na escala temporal, optamos por recuar o mínimo possível num primeiro balanço, a fim de apreciarmos a epistolografia da perspectiva de nomes ainda muito familiares e recentes, como Franz Kafka (1883-1924), Walter Benjamin (1892-1940), Fernando Pessoa (1888-1935) e Sigmund Freud (1856-1939). Em seguida, faremos alguns outros cortes no tempo, nem sempre lineares, para justapor os elementos que nos podem auxiliar na leitura das cartas das duas religiosas estudadas.

\footnotetext{
${ }^{134}$ D. Francisco Manuel de MELO, Carta de Guia de Casados, 2003.
} 
Antes de nos aproximarmos das cartas assinadas por pessoas ilustres, entretanto, aludimos aos dados dos fornecidos pelos Correios. São 850 milhões de cartas trocadas ao ano, conforme Marianne Piemonte na reportagem publicada pela Revista da Folha de 27 de maio de 2007, com o título de “Neomissivistas”. A jornalista pontua que existem muitas pessoas cuidadosas no trato com estes papéis, elas os conservam, pois têm o hábito de os enviar freqüentemente. Neste mundo de comunicação ágil e virtual, o envio de cartas sobrevive; o suporte físico mais convencional, o papel, resiste; a espera pela palavra do outro ainda é possível, tanto quanto é desejada a introspecção que nasce do confronto com a folha de papel em branco.

Também é importante recorrermos brevemente a Michel Foucault $^{135}$, para percebermos o valor da escrita na rotina que se pretende de ascese. Segundo o que o filósofo aprendeu com a leitura dos antigos (Atanásio de Alexandria, Sêneca, Plutarco, Marco Aurélio, Epiteto etc), o asceta, ao escrever, nota as ações e os movimentos da alma, vigia-se e inclusive protege-se da solidão que a sua vida impõe. A escrita assume para ele o papel da meditação, procedimento exigido dos religiosos após a Contra-Reforma. O objetivo não é apenas registrar idéias, é igualmente escrever para se corresponder. Persiste o caráter de exercício pessoal, uma vez que quem procura se corresponder ensina e aprende. Eis porque a Igreja do século XVII tomava a frente na direção espiritual das freiras, fazendo, entre outras coisas, que elas se correspondessem com religiosos ciosos da sua missão: estava de certo modo a desarmá-las, a negar a elas a hipótese de se reconhecerem na presença de um

${ }^{135}$ Cf. Michel FOUCAULT, O que é um autor?, 1992. 
outro isento, de fazerem um exame de consciência mais imparcial ${ }^{136}$, de desenvolverem a acuidade para o próprio corpo, a razão, as sensações e os sentimentos $^{137}$.

\section{Por que escrever cartas?}

Como agiam os grandes intelectuais do início do século passado, perante a necessidade de comunicar aos mais íntimos os pensamentos e os atos cotidianos, as reflexões decantadas, os detalhes de um projeto pessoal?

Franz Kafka, em 1919, dedicou-se à escrita de uma carta que resultou em cerca de cinqüenta páginas em versão editada; tal empenho, no entanto, não foi avaliado pelo destinatário, o pai do escritor, uma vez que este nunca recebeu o documento. Foram enviadas as cartas de 1921 e 1922, que colocavam Milena Jesenská na condição de interlocutora do autor de $A$ metamorfose e $O$ castelo.

Dispomos de publicações de todas estas missivas, que se tornaram referência,

\footnotetext{
${ }^{136}$ Podemos lembrar mais uma vez as palavras de Marie-Cécile Béssany-Berling. Ela externou a seguinte dúvida, no capítulo "El hermetismo de Sor Juana Inés de la Cruz", inserido na obra editada por Monika BOSSE, Barbara POTTHAST e André STOLL, La creatividad femenina en el mundo barroco hispánico, 1999: "Lo que tal vez sigue siendo materia de debate es el grado de conciencia que podía tener la monja de su propia miseria cultural” (p. 630). Na falta de um diálogo com interlocutores mais cúmplices, mais companheiros (e lembramos aqui também a importância da noção de cumplicidade neste trabalho, noção traçada a partir de Virginia Woolf, Sandra M. Gilbert, Susan Gubar e Carmen Alborch), pode ser que Sor Juana não tivesse conhecido a dimensão da sua cultura; as relações que ele pôde desenvolver trouxeram até ela proteção, mas também inveja e uma ameaça constante. A ânsia pelo saber existia em Sor Juana, a cultura adquirida, idem, mas ainda assim estava em descompasso com aquilo que poderia ter sido. $\mathrm{E}$ a limitação na correspondência está ligada a essa lacuna, agiu para manter essa lacuna.

137 Determinados trechos de Mariana Alcoforado expressam muito bem o reforço advindo da correspondência: na quarta missiva ela se aproximava da verdade por trás da dedicação às cartas: "Pareceme que te estou a falar quando te escrevo e que tu me estás um pouco mais presente” (p. 73). Em pelo menos dois fragmentos da edição de 1974 das Cartas portuguesas, Mariana assumiria que amar, comunicar e voltar-se para o seu próprio equilíbrio são processos íntimos caros à assimilação de si, pretendida e fracassada, no sentido da frustração que Severo SARDUY refere (Barroco, 1989, pp. 94-95, acerca do erotismo: é jogo, é repetição, é manipulação da desordem que o ato de escrita gera, ao invés de cessar): 1) "Só conheci bem o excesso do meu amor quando quis fazer todos os esforços para me curar dele” (p. 83); 2)“(...) sinto por mim tamanha compaixão, que terei o maior escrúpulo em pôr, nem que seja o mais ínfimo dos homens do mundo, no estado em que por culpa sua me encontro” (p. 89). Num terceiro momento, à p. 91, Mariana Alcoforado comentaria a superação do estado deplorável em que estivera. Mencionaria a mediocridade descoberta na sua condição de, ao mesmo tempo, freira e mulher apaixonada.
} 
sobretudo a primeira, com o título em português do Brasil de Carta ao pai ${ }^{138}$. Nelas remetente e destinatário desvelam-se aos olhos do leitor. Em determinadas passagens, o emissor é tão eloqüente e lúcido a respeito da sua própria condição naquele momento, quanto o que podemos encontrar ao ler fragmentos de Mariana Alcoforado. Observemos o seguinte trecho de Kafka: "Não estou de modo nenhum tão triste como se poderia crer por esta carta, só que, neste momento, nada se pode dizer” ${ }^{\text {} 39}$. O controle exercido por quem redige uma carta é patente também em Mariana: “(...) não perturbe o estado que para mim estou a preparar. (...) Não me tire desta minha incerteza. Com o tempo, espero transformá-la numa certa tranqüilidade “140.

A preocupação desses emissores para com o estado dos seus receptores mostra quanta atividade intelectual existiu e quanto investimento emocional houve antes dessa atividade que incidiu sobre o planejamento textual. A ligação que se estabeleceu entre emissor e receptor foi bem aproveitada por esses dois emissores que analisamos, pois parece que Kafka se debruçava sobre a tarefa voluntária de compreender o outro tão devotamente quanto Mariana Alcoforado, e por isso mesmo é aceitável cotejar esses textos sabidamente tão distantes em termos temporais e espaciais. Em Kafka, encontramos: "Há uma coisa que me perturba desde sempre na tua argumentação, / isso é bastante claro na tua última carta”"141. Em Mariana Alcoforado, vemos: "Detesto a sua sinceridade! Acaso lhe tinha pedido que me dissesse sinceramente a

\footnotetext{
138 Destacamos a edição preparada pela Companhia das Letras em 1997; ela tem 88 páginas. Também a editora L\&PM tem edição desta obra.

${ }^{139}$ Franz KAFKA, Três cartas a Milena Jesenská, 2003, p. 16.

${ }^{140}$ Mariana ALCOFORADO, Cartas portuguesas, 1974, p. 87.

${ }^{141}$ Franz KAFKA, Três cartas a Milena Jesenská, 2003, p. 18.
} 
verdade?”142. Mais um excerto de Kafka comprova a tendência para aderir ao gênero epistolar no que ele tem de "texto de relacionamento", por assim dizer:

"É tão triste a tua carta de hoje e sobretudo encerra de tal modo

a dor em si que me sinto completamente excluído. Quando por vezes tenho de sair do quarto, subo e desço as escadas a correr para apenas estar de novo lá e encontrar o telegrama em cima da mesa:

'Também eu estarei no sábado em Gmund'. Mas ainda não chegou nada" ${ }^{143}$.

Trata-se de discurso sobre um relacionamento amoroso, o que justifica a presença de uma tensão e de uma modulação especiais. A linguagem verbal bem trabalhada confere à mensagem escrita alguma excitação, perceptível na escolha dos advérbios, na sugestão de intensidade, no encadeamento que cresce até morrer na conjunção adversativa “mas”. Kafka nos tira o fôlego nas quatro primeiras linhas (lembrando que o manuscrito tem a configuração que mantivemos) e aplica um nome forte como "excluído”. A imagem da corrida escada acima e escada abaixo faz sentir a suspensão do protagonista das peripécias narradas na carta. A carta, portanto, fica a meio caminho entre a literatura propriamente dita e o texto de caráter referencial.

O diálogo mantido pelo casal Kafka e Milena Jesenská é rico na seleção vocabular e na combinação dos vocábulos, mas é significativamente rico também nas ausências, nas omissões. Kafka adia para outro momento,

\footnotetext{
142 Mariana ALCOFORADO, Cartas portuguesas, 1974, p. 85.

${ }^{143}$ Franz KAFKA, Três cartas a Milena Jesenská, 2003, p. 34.
} 
indefinido, a explicação sobre filhos, diz assim à p. 43: "Deixemos ainda esta questão”. Na mesma página, a propósito de uns ciúmes, ele desconversa com: “Mas agora já chega, agora fala-me de...”. Cria lacunas, portanto, as quais a própria Milena Jesenská (e nós também) preenche com expectativas, devaneios. Inseridas na poeticidade do discurso do autor, essas súbitas mudanças de rota são uma interrupção que restitui ao leitor - ou parece restituir - o controle da comunicação.

Assinalemos, por último, que o escritor utiliza um grande número de adjetivos, como podemos verificar consoante as páginas 25 (“excitante”, “emocionante”, “repugnante”, “feliz”, “lastimoso”, “imundo”, “bom”, “inimiga”, "bondosa” e "amável”, distribuídos em vinte e duas linhas que não alcançam a margem direita do papel), 26 ("pequena”, “desvairada”, “derradeiras”, “quieto”, “sacudido”, “repugnante”, “penoso” e “sórdido”) e 40 (“medonho”, “mágico”, “arquejante”, “indefeso” e “possesso”).

Na mesma década do século XX e também na seguinte, o filósofo alemão Walter Benjamin revelaria em poemas e na correspondência mantida com amigos como fora conhecer o Amor, sentimento que reconhecemos na admiração dele por uma mulher chamada Asja Lacis ${ }^{144}$. Nas cartas dele há fragmentos concernentes à presença dela, à forte impressão que ela imprimia e, igualmente, passagens feitas para publicação, nas quais o espírito do filósofo estava acompanhado do dela, tamanho o encanto que ele relata.

Em Portugal, no mesmo período, o poeta Fernando Pessoa produzia para outra mulher, Ofélia Queiroz, uma série de cartas, respondidas por ela de

\footnotetext{
${ }^{144}$ Fiquemos com esta passagem de Rua de Sentido único e Infância em Berlim por Volta de 1900, 1992: "Esta rua chama-se/ Rua Asja Lacis,/ em homenagem àquela que, /como engenheiro,/ a rasgou no íntimo do autor" (p. 35).
} 
forma vivaz e curiosamente crédula ${ }^{145}$. Os paradoxos da relação e a ingenuidade da jovem datilógrafa que o poeta namorava por carta servirão como mote para que discutamos o que a astúcia representa: em termos de recurso pessoal, favorece as relações travadas pelas mulheres nos campos em que elas pretendem se afirmar como vozes a serem ouvidas de fato.

Ofélia pode ser vista em retrospectiva como uma mulher independente: aos 19 anos já trabalhava, por exemplo, e só limitava as próprias ações por causa das opiniões da família. Por outro lado, voltou-se para as possibilidades de contrair casamento, talvez iludida com a idéia de estabilidade, num período de agitação social e disciplina imposta à força. Teve, portanto, laivos de autonomia e de atitude quanto aos projetos pessoais, mas estagnou diante das convicções e da vocação do namorado. Deu espaço para ele elucubrar, enquanto ficava a calcular (mal) maneiras de dissuadi-lo. Para além do matrimônio, que outras aspirações, ou mais ou menos edificantes, perseguiu? Fez mais algum "sacrifício” (ela usou o termo na expectativa de convencer Fernando Pessoa do quanto se entregava a ele, em detrimento da atenção que outro rapaz reclamava)? O comentário transcrito a seguir procura resumidamente enquadrar num contexto geral o que ela teve como experiência concreta:

\footnotetext{
${ }^{145}$ Fernando Pessoa encarava a questão da sinceridade e do fingimento de maneira distinta daquela que Ofélia Queiroz o fazia, tendo a diferença de perspectivas contribuído para a inserção (e a aceitação desta inserção) do heterônimo Álvaro de Campos no romance. Isto, entre outras coisas, viria a pôr fim ao namoro e, namoro retomado após um intervalo de muitos anos, viria a predispor Ofélia ao desânimo decisivo, visto que cada vez mais a obra pessoana ocupava as preocupações dele. Ainda que se comunicasse com ela, escolhia o recolhimento à própria individualidade e à devoção que a criação poética cobrava, em vez de preferir a dedicação aos apelos e às contingências de uma relação amorosa. Interessanos, entretanto, que Ofélia - muito embora volte-se para Fernando Pessoa, a fim de tentar viver de acordo com os sentimentos que nutre por ele -, admita Álvaro de Campos a interferir e a dificultar o relacionamento do casal, pois que ele nega manifestações amorosas mais espontâneas da parte do outro, o homem de carne e osso. É importante fazer constar, também, que Pessoa se aventurou na assunção dos heterónimos de tal forma que perdeu a direção da própria individualidade, o que tornava inviável uma comunicação linear com a namorada. Não era uma única voz que falava com ela, eram muitas.
} 
"Em 1930 parecia que apenas o homem estava votado a essa questa do Absoluto, cabendo à mulher aplanar-lhe o caminho e realizar-se na sombra. Aquelas que por si mesmas buscaram idêntico caminho ao longo da história, fizeram-no adentro de conventos, ou pagaram com a vida o seu atrevimento" ${ }^{146}$.

A leitura que fizemos do caso de Ofélia Queiroz nos pode ser útil na compreensão do caso de traição de Sor Juana Inés de la Cruz. Acreditamos ter ocorrido, nos dois casos, investimento feminino elevado; da parte de Ofélia, no contato com Fernando Pessoa e na espera por ele; da parte de Sor Juana Inés de la Cruz, no contato com o bispo Manuel Fernández de Santa Cruz e na confiança depositada nele. A troca entre estas duas últimas personalidades se deu por meio de cartas, a primeira delas a Carta atenagórica. Na própria missiva a religiosa remetia o destinatário para as conversas que antecederam a escrita e que eram basicamente incentivos ao ato de registrar uma crítica ao Sermão do Mandato, redigido e proferido por António Vieira:

"Muy señor mio: de las bachillerías de una conversación, que en la merced que V.md. me hace pasaron plaza de vivezas, nació en V.md. el deseo de ver por escrito algunos discursos que allí hice de repente sobre los sermones de un excelente orador" 147 .

Ainda na mesma página, lemos: "De esto hablamos, y V.md. gustó (como ya dije) ver esto escrito”. É muito clara a alusão que a religiosa faz ao estímulo que recebera de Manuel Fernández de Santa Cruz.

Sor Juana Inés de la Cruz acolheu o conselho, deu nova forma ao discurso que um grupo já ouvira (as tais palavras que impressionaram o bispo) e,

\footnotetext{
${ }^{146}$ Manuela NOGUEIRA e Maria da Conceição AZEVEDO (orgs.), Cartas de Amor de Ofélia a Fernando Pessoa, 1996, p. 28.

${ }^{147}$ Sor Juana Inés de la CRUZ, Obras completas de Sor Juana Inés de la Cruz, IV, Comedias, sainetes y prosa, 2004, p. 412.
} 
assim, repartiu com ele a responsabilidade por uma transgressão às condutas daquele círculo de pessoas. Nossa dúvida reside em ter ou não faltado a ela argúcia para perceber uma intenção destrutiva na manipulação de Manuel Fernández de Santa Cruz.

Propomos que se veja nela, a personagem histórica, perspicácia para ler, compreender e debater, porém inocência ao oferecer ao outro a ocasião para utilizar a correspondência como passarela de outros projetos. Assim, supomos que são equivalentes as situações vividas por Ofélia Queiroz e Juana Inés de la Cruz, respeitadas as muitas diferenças contextuais que as separam, já que ambas estavam imbuídas de grandes desejos, foram boas observadoras e, contrariamente às expectativas de quem examina o desenrolar de cada um dos casos, deixaram-se ficar muito suscetíveis aos planos particulares de dois homens - o que no caso da segunda será aniquilador, se lembrarmos que ela parará de estudar e terá de abjurar. Eles se alienaram do diálogo iniciado com tais parceiras, em nome de projetos que prescindiam da colaboração destas mulheres, se não as anulavam.

O caso que estudamos, o da traição imposta à religiosa novo-hispana, tem todas as características de uma farsa, criada para agradar ao bispo e ao mesmo tempo expor uma erudita em evidência. As artimanhas do bispo soam como armadilha, à qual havemos de saber por que Sor Juana Inés de la Cruz cedeu.

A hipótese mais forte neste trabalho é a de Sor Juana Inés de la Cruz ter visto a escrita para o bispo como um "investimento" numa relação e uma “atividade auto-erótica”, características atribuídas às cartas por Renato 
$\operatorname{Mezan}^{148}$. Talvez ela tenha assumido o compromisso de argumentar e de se defender - já que compreendia de forma aguda e distinta da de António Vieira as Escrituras e quase precisava pedir desculpas por isto -, como se tal acordo significasse passar a ter de fato um interlocutor e, também, organizar um discurso de que se pudesse orgulhar.

Extraídos os exemplos que desejávamos de Kafka, Benjamin, Pessoa e Freud, enfim, tomamos a liberdade de passar à obra do convertido Fr. António das Chagas, autor de cartas, poemas e romances. Justificamos essa mudança repentina no referencial temporal com a lembrança de que, já no capítulo I, várias cartas desse religioso foram consultadas em proveito do alargamento da noção de modelo literário a que estiveram sujeitas Sóror Mariana Alcoforado e Sor Juana Inés de la Cruz. Ele, além disso, traz a esta pesquisa um contributo especial por ser de nacionalidade portuguesa, por ter vivido na mesma altura que Sóror Mariana Alcoforado e Sor Juana Inés de la Cruz, por influenciar muitas pessoas como pregador e, como não podia deixar de ser, por ter escrito muitas cartas.

Tido como freirático até o ingresso na ordem de S. Francisco, em 1663, Fr. António das Chagas fez-se valer das cartas para difundir a sua atividade literária e para exercer a direção espiritual individual, sobretudo a de mulheres. Nestas últimas, ele prezava pela enunciação dos elementos

\footnotetext{
${ }^{148}$ Relativamente às cartas escritas e recebidas por Sigmund Freud, o psicanalista Renato Mezan, em colaboração para a obra organizada por Walnice Nogueira Galvão e Nádia Battella Gotlib, Prezado senhor, prezada senhora, 2000, p. 171, assim definiu este tipo de prosa, provavelmente atento ao fato de que o material analisado por ele fazia parte de um montante elevado (estima-se que as cartas de Freud cheguem a 20 mil), fora produzido com estilo e disciplina e, por estes motivos mesmo, permitia chegar a conclusões a respeito da natureza das cartas. Há pelo menos mais três textos da obra para a qual Renato Mezan contribuiu que reforçam os conceitos formulados por ele. A partir da correspondência de Madame Sévigné, de Ana Cristina César e de Machado de Assis, outros especialistas também deduziram, embora com outras palavras e em outro arranjo, que cartas são “expansões afetivas” (p. 25), são aberturas para um “eleito” (p. 97), são “olhar que se pousa no destinatário” (p. 142) e o dar-se a olhar.
} 
constitutivos da direção: "Segue-se agora tratarmos de como uma pessoa que, pela graça de Deus, se sente já fora do mundo...” (p. 80). Em certos trechos, ele foi ainda mais direto: “O argumento infalível é...” (p. 117). Mesmo nestas cartas de direcionamento espiritual, em que não apareciam nomes próprios, estava subjacente o propósito de atingir mais almas com os exemplos dados: "Ele vos guarde e guarde a todos os que lerem este papel” (p. 73). Também encontramos: “As minhas cartas, quando V.M. lhe achar alguma cousa que sem nojo possa aproveitar a alguém, mostre-as, se quiser” (p. 104).

Fr. António das Chagas era, portanto, hábil, persuasivo, tanto mais que utilizava comparações e metáforas (baseadas na Natureza, por exemplo: árvores, cisnes, orvalho) distribuídas com cuidado pedagógico. Assim como Pe. António Vieira, usou um sem número de repartições no texto, de esquemas para fazer ver as maneiras de proceder bem perante o amor de Deus.

Quanto aos temas, o religioso escolheu a paixão de Cristo e a guerra interior para desenvolver e expressou-os nas cartas, às vezes com certo radicalismo $^{149}$. Isabel Morujão, responsável pela edição das Cartas espirituais ora consultada, orienta-nos para que reconheçamos em Fr. António das Chagas uma qualidade importante e de certa forma compatível com o radicalismo: coragem. À p. 23, Morujão afirma que ele foi protagonista de um episódio público de “desabrimento” e quase o iam lançando ao rio em função de um comentário. O que depreendemos deste exemplo e principalmente do caso das escritoras que mais nos mobilizam, Sóror Mariana Alcoforado e Sor Juana Inés

\footnotetext{
${ }^{149}$ Na abertura da Primeira Carta, por exemplo, o famoso pregador utilizou os termos "arda" e "ferva" 149 , com o intuito de indicar os estados pelos quais deve passar quem se entrega a Deus. E muito embora saibamos que ele construía e aplicava fórmulas para iniciar e para encerrar os textos, é interessante apontar a insistência nessa técnica retórica: até a carta de número LXVII, o verbo "arda” apareceu dez vezes e o "ferva", seis.
} 
de la Cruz, é que não raras vezes um religioso do século XVII tinha que lidar com situações comprometedoras, em que pesavam a rigidez das hierarquias, a competitividade dos letrados, a ambivalência própria do Barroco. Nessas situações, pode ter agido com coragem e ter faltado o zelo, todavia.

O que sabemos de Fr. António das Chagas relativiza essa idéia de alguma dificuldade setecentista em conciliar intensidade e prudência. Ele persuade as leitoras a aplicarem em agradar a Deus toda a força que as move. O efeito das cartas dele, naquele contexto, não foi o de criar conflitos com o poder eclesiástico. Talvez a prudência tenha ligação com o fato de ele ter sido um missionário itinerante, mentalizado para ir aos lugares aonde era chamado, o que quer dizer que precisava da boa recepção e da adesão ao seu projeto doutrinário. Parece que uniu habilidade retórica, radicalismo e coragem a cautela. Aproveitemos, então, para refletir sobre o comportamento de Sor Juana Inés de la Cruz frente à exposição pública.

Pode ter sido mais aliciante para ela a oportunidade de se manifestar na Carta atenagórica, porque o convívio intelectual no convento onde ela residia era parco, como já demonstramos algumas vezes nesta tese; porque ela, assim, estava a edificar um projeto pessoal, do qual teria motivos para sentir orgulho, conforme já defendemos neste mesmo capítulo, a partir das palavras de Renato Mezan; porque até aquele momento Sor Juana tinha travado relações quase brandas ${ }^{150}$ : teve em Antonio Núñez de Miranda um confessor que, apesar da fama de implacável e de calculista, lidava com ela sem incidentes; tinha em

\footnotetext{
${ }^{150}$ Um episódio passado entre Sor Juana e outra religiosa do convento será aqui resgatado, para criarmos um retrato mais completo e, quem sabe, mais fiel da personalidade da monja e dos conflitos internos que ela tinha de enfrentar: "En una ocasión una superiora se quejó de la altanería de sor Juana - imputación quizá no del todo falsa pues Oviedo veladamente le hace el mismo reproche - y la acusó de haber replicado a una observación suya en estos términos descomedidos: 'Calle, madre, que es tonta.' El arzobispo escribió al margen de la queja: ‘Pruebe lo contrario y se le hará justicia’”. (p. 190).
} 
Francisco de Aguiar y Seijas, este sim, um inimigo temível, pois rigoroso, avesso às artes e às mulheres, e que deve ter-se sentido atacado quando os ataques a Vieira foram denunciados; antes disso, porém, não parece que repreendia Sor Juana pelas atividades literárias. Além dessas razões para arriscar-se, ela não estava a serviço da religião no mesmo sentido que Fr. António das Chagas, estava mais restrita ao claustro, por exemplo. Por isso tudo, ao exercer as atividades que lhe competiam, e tendo manifesta vocação para a literatura, não enxergou muito bem as razões - que hoje sabemos suficientemente fortes - para agir com cautela e disciplina no caso da contestação do Sermão do Mandato.

Ainda no âmbito da exposição a um presumível julgamento como consequência da divulgação da Carta atenagórica, sugerimos as pistas que D. Francisco Manuel de Melo deixou. Para aprofundarmo-nos na história de Sóror Mariana Alcoforado e de Sor Juana Inés de la Cruz, podemos recordar que ele e Fr. António das Chagas preservaram o destinatário das cartas sob um neutro "N”151. Sóror Mariana Alcoforado não se esforçou, propriamente, para ocultar ou proteger o destinatário das cartas, na medida em que enumerou indicações de quem se tratava: 1) na segunda carta ela falou no país do destinatário, a França (voltando a fazê-lo na quarta carta, por duas vezes, e na quinta carta); 2) falou em dois criados portugueses que o serviram (os quais ela nomeou e que, além disso, foram apresentados em nota da edição original); 3) falou num militar a ele associável (o que ela voltaria a fazer na quarta carta também, por duas vezes); 4) falou, mas isto apenas na quarta carta, no tempo que já passara desde o romance, bem como no motivo que o levara a Portugal, a Restauração; 5) falou,

${ }^{151}$ D. Francisco Manuel de Melo, na realidade, utilizou ou "V.M.” ou "senhor N”. A página de rosto da edição recuperada de 1651 traz "A um amigo", que ele mais à frente na obra identifica como um "primo". 
igualmente na quarta carta, na existência de um irmão e de uma cunhada dele ${ }^{152}$; 6) sem contar nas muitas vezes em que, pela linguagem, parecia a própria amante abandonada, a repetir o que fora a paixão, o prazer, a conquista etc. Sóror Mariana, no que diz respeito à assunção da sua condição de autora, talvez tenha sido mais previdente. Não assinou e em 1669 o texto levado a público era anónimo. Havia uma referência a "Marianne”, uma freira portuguesa. O nome completo, com uma imprecisão (seria dado como "Mariana Alcoforada”), foi proposto pelo erudito Boissonade, já no século XIX, com base num manuscrito. Essa forma de identificação estava acompanhada de outra, era o local onde esta freira estaria, um convento em Beja, Baixo Alentejo.

Sor Juana, num comportamento teatral, ter-se-ia iludido (ou divertido?) com um destinatário preservado pelo uso de pseudônimo? A adoção de pseudônimo tem o poder de predispor o leitor à curiosidade e talvez também o arroje a criar conflitos para chegar à descoberta da verdade. No texto publicado no ano de 1690, o nome dela aparecia na página de rosto, tanto quanto o do convento, ao passo que o de Manuel Fernández de Santa Cruz, não, em seu lugar estava "Sor Fillotea de la Cruz”. Também a linguagem que ela utilizou, pelo respeito que denotava pelo destinatário, podia fazer crer que se tratava de outra monja muito distinta.

Os religiosos novo-hispanos do período de Sor Juana Inés de la Cruz estavam muito implicados com o poder laico. A biografia preparada por Octavio Paz alude aos jogos de poder entre religiosos com elevadas posições na hierarquia da Igreja. A ousadia e a exploração da criatividade têm preço; não

\footnotetext{
${ }^{152}$ Luciano CORDEIRO, em Soror Mariana, 1890, p. 154, diz: "Nos fins de 1660 (...), Chamilly assistia ao casamento do irmão mais velho, Herard Bouton (...). É a este irmão e à cunhada, - Catharina Le Comte de Nonant (...), que deve referir-se uma passagem das Cartas da religiosa portugueza...”.
} 
sabemos das consequências que teriam atingido Sóror Mariana, se foi de fato ela a autora de Cartas portuguesas, mas sabemos que Sor Juana abjurou.

Relativamente ao conteúdo da obra Carta de guia de casados, de D. Francisco Manuel de Melo, encontramos argumentos para supor que toda a reflexão foi engendrada do ponto de vista masculino. Exemplo: o casamento proporciona descanso ao homem, quando este atinge uma certa idade; o casamento pode ser leve, se o homem for prudente; o homem corresponde ao Sol e a mulher, à Lua (havendo neste caso campo para questionarmos, na atualidade, os valores atribuídos a Sol e a Lua); o homem deve casar com mulher nova, para educá-la. Segundo o autor, enfim, é exemplo da agudeza de um discreto que: "Sofra o marido à mulher tudo, senão ofensas; e a mulher ao marido ofensas e tudo” (p. 70).

A mulher, por sua vez, surgia nas considerações de D. Francisco Manuel de Melo como centro do debate em casos que diferem muito dos elencados acima: no início da obra, ele diz que a mulher esquece a família quando recebe mimos do marido. Depois, postula:

"Dê-se-lhe a entender à mulher que a cousa que mais deve querer é a seu marido, tenha o marido para si que a cousa que mais deve querer é a sua honra e, logo, sua mulher" (p. 65).

D. Francisco Manuel de Melo gastou páginas a enumerar os defeitos da mulher (ciúmes, excessos nos gastos, impertinência para com os criados etc) e a aconselhar o marido quanto ao modo de tratá-los. Vale lembrar, inclusive, que ele utilizou vários adjetivos. Muitos são pejorativos e tentavam caracterizar os diferentes tipos de mulher, vistos da perspectiva do autor: "braba” (p. 66), “feia” 
(p. 67), “nécia” (p. 67), “umas que se prezam de fermosas” (p. 71). Das teimosas ou presunçosas ele diz, à p. 70:

"Mostre-se-lhe às vezes que, havendo quando se casou entregado sua vontade ao marido, comete agora delito em querer usar de aquilo que já não é seu”.

Ainda dentro do recorte das opiniões acerca das mulheres, fica registrado que: as mulheres devem ser "graves”, a não ser em casa, com marido e filhos, onde e com quem podem rir.

O texto da p. 138 é importante, porém, porque pode ser assumido como defesa das mulheres, se comparado ao restante da exposição de D. Francisco Manuel de Melo:

“(...) sucede de ordinário que nas casas ilustres $e$ grandes, donde há muitas filhas, apenas pode haver dote com que casar uma como convém. Ficam logo as outras condenadas a perderem por força a liberdade e haverem de tomar esta do que não desejam e violentissimamente sofrem".

Em relação à religião da mulher, pregou o autor na Carta de guia de casados: 1) a mulher deve confessar, receber religiosos em casa com reservas e nunca consultar adivinhas; 2) aconselha também a penitência (“A mulher boa que sem excesso se mortifica é digníssima”, pp. 103-104); 3) “Mosteiros, recolhimentos e outros resguardos semelhantes em que os homens depositam suas mulheres não deixam de ser arriscados e, decerto, quando a ocasião não seja muito urgente, é usar com as palavras ruim lei e faltar-lhes com a fé e companhia devida, porque se cada uma daquelas quisera ser freira bem escusara de se casar” (p. 131). Cumpre relacionar os números 1, 2 e 3 ao fato de D. 
Francisco Manuel de Melo ser "homem fundamentalmente religioso e fiel catholico"153, o que terá motivado a atenção que dedicou aos referidos pontos.

Passamos a transcrever as seguintes referências ao corpo/à beleza: 1) “Desejo que da fermosura se use como da nobreza: folgue cada um de a ter, mas que não a mostre. Levar da espada a cada passo argue pouca prudência. $\mathrm{O}$ marido que vir sua mulher inclinar a esta vanglória viva por ela mesmo avisado e saiba que tem perigosa mercadoria, sendo esta das mulheres ao revés que as outras, pois, quanto mais cobiçada é, menos para cobiçar. E por esta razão não faltou já quem duvidasse se a fermosura se dava por prémio se por castigo” (p. 71). Novamente, o corpo, agora como fundamento para uma analogia: 2) "Verdadeiramente, senhor N., que podemos afirmar que, assi como entre a cabeça e mais partes do corpo humano convém que haja grande conformidade para que vivamos com saúde, assi também entre o senhor da casa e os familiares dela convém que haja concórdia para que se possa viver com gosto e quietação” (p. 79).

Outra referência ao corpo, à p. 121, condena que o marido fale aos amigos sobre as partes de sua mulher, hábito que, por estar aludido, devia ser comum: 3) "Não são poucos, nem pouco grandes, aqueles que, entremetendo de cortesãos ou engraçados, gabam em público as partes de suas mulheres ou falam nelas; cousa, a meu juízo, indigníssima e digníssima de grande reprensão”.

Observemos mais algumas perspectivas e excertos: 1) a proporção no casal (de idade, por exemplo) deve ser respeitada; 2) os exageros no amor são desaconselhados; 3) “Em nada deve haver excesso na casa bem regida” (p. 74): da soma destes três pensamentos e/ou formulações deriva que a harmonia

\footnotetext{
${ }^{153}$ Edgar PRESTAGE, D. Francisco Manuel de Melo, 1996, p. 404.
} 
(aquela que um homem discreto do século dezessete concebe como tal) é o tom do livro. Há, contudo, desequilíbrio no que tange o comportamento desejável para homens e para mulheres, conforme evidenciaram os dois primeiros tópicos desta parte do trabalho. Segue um exemplo em que um tema dá margem ao comentário sobre a atitude desejada do homem e a da mulher: 4) "Não se nega porém ao marido que se possa mostrar galante com as damas e senhoras quando a ocasião for de galantaria, porque esta obrigação é de bom sangue” (p. 110). Ainda: 5) "Estas galantarias do marido não podem ser recíprocas para a mulher, que tem muito menores licenças, sem ter alguma razão de queixa” (p. 111).

Chegamos, assim, à conclusão do livro:

"Senhor meu. Casa limpa. Mesa asseada. Prato honesto. Servir quedo. Criados bons. Um que os mande. Paga certa. Escravos poucos. Coche a ponto. Cavalo gordo. Prata muita. Ouro a menos. Jóias que se não peçam. Dinheiro o que se possa. Alfaias todas. Armações muitas. Pinturas as melhores. Livros alguns. Armas que não faltem. Casas próprias. Quinta pequena. Missa em casa. Esmola sempre. Poucos vizinhos. Filhos sem mimo. Ordem em tudo. Mulher honrada. Marido cristão. É boa vida e boa morte" (p. 144).

A idéia de equilíbrio de D. Francisco Manuel de Melo corrobora o que se conhece de muitos textos mais antigos que o dele, os quais viam no casamento uma solução, uma forma de remediar, por exemplo, a característica da "mulher, sobretudo a jovem, sempre muito identificada com a tentação da concupiscência”154.

Na Idade Média - e aqui está nosso outro corte no tempo, mais uma vez justificável - fomos buscar quatro cartas de Santa Clara de Assis endereçadas a Santa Inês de Praga. Há além disso uma quinta carta, dirigida a

\footnotetext{
154 “Viúvas ideais, viúvas reais. Modelos comportamentais e solidão feminina (séculos XVI-XVII)”, Faces de Eva - Estudos sobre a mulher, p. 54.
} 
Ermentrudis de Bruges, cuja autenticidade é contudo contestada. E por que as escolhemos, se vínhamos tratando de missivas muitos anos mais recentes do que essas? Porque, no caso de Sóror Mariana Alcoforado, a correspondência circulava de mulher para homem - com algum discurso indireto sobre as cartas que o homem teria mandado à mulher; no caso de Sor Juana, as declarações feministas pareciam ser o produto do debate entre mulheres, embora não fossem. No caso de Santa Clara, a ponte de mulher para mulher era sólida, verdadeira. As cartas datam aproximadamente de 1234, 1235, 1238 e 1252, a redação original foi feita em latim, e foram descobertas numa biblioteca italiana entre a primeira e a segunda década do século XX. Grosso modo, dão vazão à pregação de Santa Clara. A segunda, por exemplo, foi escrita pela religiosa fundadora do braço feminino da Ordem de S. Francisco por ocasião de outra carta, a "Cum relicata saeculi”, em que o Papa tenta fazer Inês de Praga aceitar propriedades. Santa Clara reconheceu a pressão exercida sobre a moça nobre, recém-admitida pelas damianitas, e resolveu reforçar a idéia de devoção, de atenção ao voto de pobreza. Louvou as virtudes de Inês de Praga, para aconselhar a manutenção da conduta.

Ao aconselhar com rigidez, a religiosa deixava entrever o diálogo que era mantido por meio das cartas, uma vez que estava a atender a um chamado: "Mas não quero terminar sem dar resposta à questão que, em caridade, me puseste” (p. 49). Em determinadas passagens, ele assumiu um tom muito acolhedor, o que se verifica pelo uso de um "tua mãe” (p. 55) e a seguir um "esta expressão de afeição maternal” (p. 57).

As fórmulas são transparentes: "Eu te exorto a teres sempre presente o teu santo propósito e qual outra Raquel (Gen, 29, 16), não percas de vista as 
motivações do início” ${ }^{155}$. Localizamos vários marcadores, isto é, conectivos que dão coesão ao texto da religiosa, tais como “portanto” (p. 30), “Se”, “ou... ou”, “Assim”, todos à 31, mais "Por isso” (escrito duas vezes numa sequência de parágrafos) e “por último”, ambos à p. 32. Trata-se de uma estrutura útil à argumentação. Há que se mencionar, igualmente, a escolha de verbos no modo imperativo, a saber "segue”, "Prefere”, “Olha”, “medita” e “contempla”, "Sê” colocados os primeiros dois na p. 38 e os restantes na 39. Convém acusar a presença de pergunta retórica à p. 47:

"Não é verdade que assistida pela Sabedoria divina, triunfaste de maneira surpreendente sobre a astúcia do inimigo, sobre o orgulho e a vaidade, causa da loucura e perdição do coração?”

Há comparação à 49:

"Tal como a Virgem das virgens o trouxe materialmente no seu seio, assim também tu o podes trazer, sem dúvida alguma de maneira espiritual, no teu corpo casto $e$ virginal, seguindo as suas pegadas, sobretudo a sua humildade e pobreza".

\section{Argumentos para caracterizar a dicção feminina}

Uma vez que nos propusemos a examinar a teoria que desde há muitos anos vem sendo feita acerca da dicção feminina, apontamos agora os seus autores em ordem cronológica; iremos dos estudos mais antigos aos mais recentes, para verificar se apontaram traços que permitem ler com mais propriedade as cartas de Sóror Mariana Alcoforado e as de Sor Juana Inés de la

\footnotetext{
${ }^{155}$ Santa Clara de ASSIS, Cartas a Santa Inês de Praga, 1993, p. 38.
} 
Cruz $^{156}$. Buscamos, assim, um método que veja a mulher e a literatura em suas especificidades. Havemos de consultar João da Silva Correia, que em 1935 publicou A linguagem da mulher, passados oito anos de uma série de lições dadas em Coimbra; Robin Tolmach Lakoff, que em 1975 publicou Language and woman's place e, desde então, vem causando polêmica no ramo dos estudos sociolinguísticos; Roland Barthes, que em 1977 publicou Fragments d'un discours amoureux; Ana Vicente, que em 1987 publicou Mulheres em discurso, depois de ter lido, selecionado e estudado 700 cartas enviadas por mulheres portuguesas à Comissão da Condição Feminina, entre 1979 e 1982, no âmbito de um projeto nacional sobre planejamento familiar. A lista é encabeçada e encerrada por investigadores portugueses que trabalharam com exemplos dessa língua - além de exemplos do francês, no caso de João da Silva Correia.

João da Silva Correia defendeu seu objeto de estudo de maneira muito clara e sucinta e se fez valer de muitas citações que, no entanto, não sentimos necessidade de transcrever: “(...) embora entre os dois sexos não haja divergências essenciais, o modo de expressão não é, em verdade, rigorosamente o mesmo” (p. 10). Separou as divergências linguísticas que defendia em quatro conjuntos, a saber: 1) auxiliares da linguagem; 2) léxico; 3) gramática; 4) estilo.

\footnotetext{
${ }^{156} \mathrm{O}$ desejo de procurar traços de feminilidade em Sóror Mariana não é tão linear quanto possa parecer. Não se trata de tentar provar a autoria das cartas (cartas de mulher, logo cartas de Mariana) até porque, como refletiu Maria Teresa Arsénio NUNES ("Sinceridade e epistolografia. Como o verde nas folhas", Colóquio/ Letras, ${ }^{\circ}$ 140/141, 1996, pp. 61-70), num excerto que decidimos citar sem muitos cortes, mesmo sabendo do risco de abusar do recurso à autoridade: “(...) o conceito de sinceridade é à partida muito equívoco. Não se faz melhor ou pior literatura por se ser mais ou menos inocente; mas já a verdade de uma carta - isto é, aquilo que, ao lado de uma eventual qualidade literária e tanto quanto essas águas se possam separar, é a imanência da sua própria linguagem e como tal perdura na letra do texto - pode depender da sinceridade que nela se põe (...) De Soror Mariana - e se as encararmos assim, pelo seu lado estritamente formal mesmo quando do conteúdo da sua mensagem se trata, torna-se afinal pacífica a questão da autoria das Cartas Portuguesas". Ao longo de toda a tese procuramos resolver ou respeitar a dúvida quanto à autoria, mediante o uso de pequenas fórmulas, tais como "cartas atribuídas a Mariana”; de todo modo, cremos que, mesmo que a obra tenha nascido de um artifício masculino, terá sempre de ser lida como retrato da paixão de uma mulher, porque de uma mulher a falar sobre paixão se trata. Nosso desejo esteve e está muito mais em averiguar a possibilidade de Cartas portuguesas ser uma obra escrita por mulher; e em provar que a presença da mulher no sistema literário outorga a todas as escritoras o poder de reler, de enfabular numa linguagem própria que seja reconhecida como válida.
} 
Do primeiro conjunto, destacou: o suspiro, o gemido, o pranto, a vivacidade gesticulatória e o jogo fisionómico de lábios e olhos. Do segundo conjunto, ressaltou: os neologismos, as palavras abstratas, a polissemia, os arcaísmos, as interjeições, as locuções exclamativas, os diminutivos, os hipocorísticos e os estrangeirismos. Do terceiro conjunto, salientou aspectos que de todo não nos assistem, como a ortografia e a fonética; também passou: pelos superlativos, pelas repetições, pelo uso do pronome pessoal eu, pelo pleonasmo, pelo anacoluto, pela ordem indireta e pelos eufemismos. Do quarto e último conjunto, evidenciou: a concretização plástica, o misticismo, a riqueza de sensibilidade, o verniz retórico, o gosto pelo pormenor e pelo recurso ao discurso direto. Há no livro de João Correia da Silva um tópico dedicado às “notas literárias”, mas nada há sobre as Cartas portuguesas, o que não conseguimos explicar, se lembrarmos que por aquela altura Mariana Alcoforado estava integrada ao cânone português. Curiosamente, são citados dois autores, um francês e outro português, que contribuíram para a literatura com textos misóginos, são eles Rousseau e Baltasar Dias. Rousseau foi citado porque dissera que a mulher era hábil em dissimular e Baltasar Dias foi referido duas vezes, porque fizera troça da tagarelice feminina na obra Conselho para bem casar, e porque, nessa mesma obra, falara dos “excessos de linguagem” da mulher (p. 89).

Robin Lakoff, professora da Universidade de Berkeley, manteve o mesmo foco que Correia, mas em vez de exemplificar por meio da literatura e de fragmentos da teoria de outros linguistas, preferiu uma exposição baseada em padrões, isto é, centrada na comparação entre sentenças que os homens costumeiramente utilizam e sentenças que as mulheres aprenderam a usar desde crianças (“woman talk”, “women’s language”). A cada uso, ela acrescentou 
comentários acerca do contexto, de forma a demonstrar que um padrão tem mais força e consequentemente mais aceitação social do que o outro ${ }^{157}$. O padrão masculino confere ao falante uma posição de comando, na medida em que ele evidencia mais segurança, menos necessidade de partilha com o interlocutor etc.

Roland Barthes, por outro lado, deu elementos ao leitor interessado em pensar as Cartas portuguesas, mesmo sem ter utilizado qualquer exemplo extraído delas em Fragmentos de um discurso amoroso. Ele igualmente não discorreu sobre a diç̧ão feminina, mas o incluímos neste tópico mesmo assim porque, desde o princípio do livro, deu pistas sobre como se estrutura um discurso acerca do amor. Num parágrafo isolado, disposto antes do princípio da argumentação propriamente dita, Barthes situou o interesse pelo discurso amoroso. Segundo ele, na atualidade (embora o período não tenha sido delimitado pelo escritor) já ninguém valoriza os discursos sobre o amor e ninguém os defende, portanto. À p. 12, concentrado em explicar o método usado no livro, ele apontou que: “O apaixonado não deixa, na verdade, de correr dentro da sua cabeça, de empreender novas tarefas e de fazer intriga contra si próprio”. A observação só vem a confirmar uma constatação de leitura exposta e comentada no capítulo I: a repetição que atravessa as Cartas portuguesas pode ser barroca e pode ser do discurso amoroso. Barthes ainda acrescentou, na mesma página, que, por causa dos rompantes, o apaixonado só consegue construir um discurso com quebras de continuidade - ou com menos coesão, aos olhos de quem não comunga daquela paixão, mas tem de ler a sua mensagem, mesmo assim -, marcado por figuras, isto é, por gestos simbólicos, como o

\footnotetext{
${ }^{157} \mathrm{E}$, afinal, não é disso que os dois casos que estudamos tratam? Será que alguns dos temas de Sor Juana, tratados como elas os tratou, receberiam outro rótulo, se tivessem outra assinatura? Porque o padrão usado por ela não faz concluir por si só que seja inequivocamente um texto de mulher.
} 
abraço e o choro, estados de alma, como a angústia e os ciúmes, materializações, como as cartas de amor e a dedicatória. A ausência de resposta (a que a remetente das Cartas portuguesas, por exemplo, afirma ter sido submetida) aparece como um dos enquadramentos do discurso amoroso visto por Barthes. O querer-para-si, fingindo não querer, está na concepção de discurso amoroso de Barthes como está no texto de Mariana Alcoforado, que reclamava a presença do amante, os prazeres que estavam nos planos dos dois, os elogios que ele faria (à beleza dela, por exemplo), a partida de Portugal, as notícias de todos os lugares por onde Chamilly passasse, a fidelidade, a saúde já quase arruinada, a paga dos sacrifícios que fez ao se expor, a direção que esse amante podia dar ("Trata-me com severidade! Não aches que os meus sentimentos têm violência bastante! Sê mais difícil de contentar! Ordena-me que morra de amor por ti!”158) etc. A sedução, entendida por Barthes como episódio inicial dos amores, aparecia em Cartas portuguesas, como já salientamos no capítulo III e voltaremos a salientar no V, ao lembrar da impressão que o garbo de Chamilly deixara em Mariana. A incapacidade de estabelecer ligações marca o ser apaixonado - e de alguma forma ele a comunica ao leitor -, por isso foi explorada por Barthes, a partir da p. 236, e igualmente se depreende do texto seiscentista que estudamos porque, saibamos da biografia da sua presumível autora ou não, essa remetente não se evidencia pela natureza religiosa; Mariana não dá a entender que se (re)ligara a Deus, à rotina do convento, à Natureza. A relação que ela estabelecia com o mundo exterior era por ela depreciada, incluindo a possibilidade da religião. À p. 134, Barthes mostrou a oscilação com que um amante vive a espera do amado, aludindo à violência e à serenidade que rondam esse amante, como se ele tivesse

\footnotetext{
${ }^{158}$ Mariana ALCOFORADO, Cartas portuguesas, 1974, p. 47.
} 
sido vítima de um encantamento; Mariana dava mostras da mesma instabilidade, expressa na diferença de ritmo entre uma carta e outra, a que aludiremos ainda neste capítulo.

Já Ana Vicente, membro de uma equipe do governo português, não trabalhou no meio universitário para a produção de conteúdo científico de aplicação social, como fizeram Correia e Lakoff, nem para a análise do discurso que visa a enriquecer os estudos literários e semiológicos, como fez Barthes. Dividia com uma colega, Maria Reynolds de Souza, a responsabilidade por desenvolver um programa de planejamento familiar, a partir da comunicação com mulheres de níveis de escolaridade precários e médios, isto é, analfabetas, semianalfabetas e com nível de instrução mediano. A dupla atou em três frentes, a saber: numa revista chamada “Crónica feminina”, na elaboração de material didático e nas tarefas ligadas a várias outras organizações, governamentais e não-governamentais. O segmento do trabalho delas que nos interessa nesta tese é o da colaboração com a referida revista. No livro Mulheres em discurso, Ana Vicente relatou que a publicação tinha tiragem de 200.000 exemplares, havendo estimativa de que cada um fosse partilhado por três leitoras. A essa publicação um certo grupo de jornalistas foi ao longo do tempo fornecendo textos sobre planejamento familiar, ao fim dos quais repetia sempre o convite à escrita de cartas, para que as leitoras participassem do processo de uma forma mais ativa. De um total de aproximadamente 10.000 cartas, Ana Vicente separou 700 para análise $^{159}$. Fez uma classificação por região, mas também por sexo, por idade, por temas e pelo uso da linguagem.

\footnotetext{
${ }^{159}$ Dessas 700 cartas, 25 foram escritas por leitoras da cidade de Beja, onde viveu Mariana Alcoforado. O critério de seleção não era geográfico, o que quer dizer que Ana Vicente, já assumindo as funções de
} 
Para se aproximar das cartas, podendo decifrar-lhes a linguagem, voltou a João da Silva Correia, a Robin Lakoff e a Álvaro García Meseguer citando Barthes aqui e ali, embora estivesse a dialogar com o Barthes de Lição $^{160}$, e não o de Fragmentos de um discurso amoroso. Acabou por reforçar, no que toca a dicção feminina, os pontos de vista que esta tese já salientou, mais um ou outro aspecto bastante lógico ou prático, que passamos a citar ou indicar sucintamente: 1) “Ora, se como é geralmente aceite, a linguagem é um veículo de comunicação que nos possibilita a expressão, então também o comportamento linguístico é mais uma das facetas do comportamento” (p. 43); 2) “A linguagem serve-se de nós tanto como nós nos servimos da linguagem” (p. 44); 3) a linguagem da mulher, segundo pesquisa de Lakoff, transparece mais insegurança, mais delicadeza, mais cortesia e menos recurso à afirmação categórica, porque as características opostas a essas atrairiam o rótulo de masculinidade; 4) "Para alguns filólogos, não se põe apenas a questão de a linguagem influir sobre a nossa forma de perceber a realidade, mas antes que influi na própria realidade” (p. 46). O segundo aspecto era citação de texto de Robin Lakoff e o último, citação de García Meseguer.

\section{As cinco cartas de Sóror Mariana Alcoforado}

Excetuados os pontuais exames das cartas distribuídos nos capítulos anteriores e aqueles que reservamos para o próximo capítulo, apresentamos agora mais algumas considerações acerca das Cartas portuguesas para as quais chamamos atenção.

investigadora neste caso, não privilegiou a cidade tanto quanto qualquer outra, para montar um panorama ilustrativo dos interesses femininos portugueses.

${ }^{160}$ Roland BARTHES, Lição, 1979. 
Faremos uma análise parcial, para destacar os excertos dedicados à valorização do olhar em quatro das cartas de Mariana Alcoforado, uma vez que neles há reflexos do cruzamento entre texto verbal e imagético, tópico referido mais largamente no capítulo III.

A freira portuguesa, na primeira de suas cartas, referiu-se a "olhos", a "luz" e a "beleza". Ela não estava, no texto em prosa, a copiar com palavras uma pintura, nem a elogiar o trabalho que resultava de uma pintura ou o objeto magnífico à disposição do talento de um pintor; porém ressaltava o poder dos olhos, o foco dado por uma luz, como se num primeiro momento esses fossem os movimentos do escritor, como se o olhar, direcionado pela luz, conduzisse ao ato de escrever.

Encontramos na primeira carta uma seqüência de termos alusivos ao sentido da visão que vai da p.13 à 17 e é formada por "olhos" (p. 13 e p. 19), "luz" (p. 13 e p. 17), "ver-te" (p. 17) e "beleza" (p. 17), sendo este último um atributo essencialmente visual do qual a autora voltaria a tratar à p. 61, na quarta carta.

Mariana estava a construir uma exposição dos acontecimentos recentes da vida dela, fixada no encanto que os olhos do amado haviam provocado. É um exemplo da utilização do poder que a imagem condensa, transmitido pelo código verbal escrito:

“(...) E esta ausência, para a qual a minha dor, por mais que se esforce, não consegue encontrar um nome assaz funesto, há-de então privar-me para sempre de fitar esses olhos onde eu via tanto amor, esses olhos que me faziam saborear emoções que me cumulavam de alegria, que eram o meu tudo, a tal ponto que deles só precisava para viver” (p. 13) 
Já num pequeno trecho da segunda carta, à p. 29, Mariana falava na “cegueira” que a levara à desgraça (de dedicar-se a alguém que não lhe daria mais prazer) e no desconsolo: "não hei-de tornar a ver-te no meu quarto”.

Da quarta carta, é importante salientar o reaparecimento da idéia de cegueira (“Não estavas tu tão cego como eu!”, p. 61) e a mudança considerável de tom, com relação à primeira carta. A religiosa deixada por Chamilly passaria a discorrer sobre as evidências da ilusão a que esteve ligada, sem priorizar o discurso a respeito do prazer em servir o amante mesmo após o abandono. Ela tornaria a falar em beleza, ponderando que ele poderia ter encontrado em Portugal mulher mais bela. Trata-se de argumento que remete o leitor a um estereótipo, a um perfil de amante que se poderia levantar dúvida se estaria em conformidade com os padrões estéticos do período ou não. Mariana seria, por esse raciocínio, sensível quanto ao imaginário dos receptores de um discurso como o dela? Leria outras epístolas? São perguntas pelas quais já passamos no capítulo I, sem encontrar respostas definitivas. A freira se apresentava como uma injustiçada, a fim de que pudéssemos vê-la assim também; ela punha diante de si um espelho e nos oferecia exatamente esse retrato.

Não cabe procurarmos em Mariana Alcoforado a perfeição, o ponto máximo do artifício barroco, mas talvez a conjunção entre a carga emotiva e o bom uso de modelos retóricos responsáveis por aproximar o leitor da vitalidade que se espera do discurso amoroso.

Nessa mesma carta, a quarta, existe uma passagem, precisamente à p. 67, que parece ter sido redigida com o intuito de recompor a história do casal desde os momentos iniciais: 
"Vi-te muitas vezes passar neste lugar com um ar que me encantava, e eu estava naquela varanda naquele dia fatal em que comecei a sentir os primeiros efeitos da minha infeliz paixão. Pareceu-me que me querias agradar, embora nem me conhecesses. Convenci-me de que me tinhas notado entre todas as que estavam comigo, e imaginei que, quando passasses, ficarias contente se eu te visse melhor e se admirasse a tua destreza e a boa graça quando montavas o teu cavalo."

O trecho contém uma descrição da troca de olhares entre os amantes, com ênfase para a comunicação que se faz possível por meio dela. Mariana mostrava o quanto se consegue intuir (ou se deseja intuir) a partir de um contato travado dessa forma, ou seja, sem palavras.

Finalmente, na quinta carta, a religiosa franciscana mencionaria um retrato dado a ela. E devolvido a ele. Ela caracterizava esse objeto e outros como “testemunhos do seu amor” (p. 81). É justo afirmarmos que ela confirmava a estratégia de valorizar o aspecto visual, no relacionamento com o amante e na construção textual, como se pode verificar com base no seguinte fragmento: “Confesso, para vergonha minha, e sua, que me achei muito mais presa a estas bagatelas do que quero confessar.” (p. 81)

Em segundo lugar, salientamos elementos presentes nas páginas 41, 45, 63 e 69 das Cartas portuguesas, por identificá-los como semelhantes e/ou complementares no que tange o assunto e a abordagem.

O primeiro aspecto, o que nos leva a apontar a p. 41, prende-se com a noção de projeto perspectivada por Mariana Alcoforado. Ela utilizou a locução verbal “tinha previsto”, a forma verbal conjugada “esperava” (por duas vezes seguidas), a locução verbal “tinha pensado” e o substantivo “projecto”, para organizar idéias em torno do futuro. O impulso inicial a levara a questionar: “Que irá ser de mim e que queres que faça?”, mas tinha ela mesma a resposta para a pergunta, baseada no que havia andado a fazer: “combater senão contra 
mim própria”. Isso significa que as cartas podem ter oferecido a ela, no momento da enunciação, e a quem as leu depois de prontas, uma oportunidade para pensar a noção de realidade que vem das mulheres, tantas vezes confundidas com seus papéis sociais. Mariana ou o mito que se criou no século XVII, não importa neste caso, ajuda-nos a perceber quão arraigadas estão as promessas de um traçado colorido, linear e ininterruptamente reconfortante no destino de uma mulher. São as palavras ternas dos pais para as meninas, são as tarefas designadas como femininas, é a imposição da maternidade, é a vergonha do corpo e da sexualidade. Parecem clichês, mas que matéria para reflexão dariam em 1668? Colocariam uma mulher contra o que outros pregavam como sua natureza mais profunda, mais autêntica? Na atualidade, ainda obrigam a muita auto-análise, o que com a leitura de Novas cartas portuguesas tentaremos demonstrar no capítulo a seguir a este.

O segundo aspecto, legível na p. 45, está igualmente relacionado com a dúvida/confusão que assalta tantas pessoas e que fragiliza tantas mulheres. Mariana dizia: "Eu não sei nem o que sou, nem o que faço, nem o que desejo: encontro-me dilacerada por mil movimentos contrários”. A mortificação combinava bem com o espírito barroco, conflituoso. Mais uma vez está assente para quem lê que a emissora da mensagem sofria, não passava pela busca de resposta impunemente.

À p. 63, ela tornaria a se mostrar insatisfeita e inquieta, quando fazia as seguintes comparações:

"A tua família tinha-te escrito: mas não conheces tu quantas perseguições eu sofri por parte da minha? A tua honra impunha-te que me abandonasses: preocupei-me eu alguma vez com a minha? Sentias-te na obrigação de ir servir o teu rei: se é verdade o que se diz, não tem ele qualquer necessidade do teu 
auxílio, e certamente te haveria escusado".

A revolta dela nos alerta para o fato de que confundia de novo a esfera dos cuidados e das responsabilidades pessoais com a esfera dos papéis sociais. Ela perspectivava o casal frente às duas famílias, a honra de um versus a de outro, as obrigações dele versus o subentendido imobilismo dela, presa no convento. Sabemos que o debate sobre a honra, naquele século e no seguinte, tumultuava as consciências e tinha desdobramentos: fez muitas cartas apologéticas serem levadas a público em defesa de um e de outro sexo. Nem é preciso sair do gênero epistolar, para encontrar na Biblioteca Nacional de Portugal uma série de textos deste tipo, às vezes sérios, às vezes jocosos ${ }^{130}$. Compreende-se, então, a origem da convulsão em Mariana. Ainda assim, permanece a lacuna. Que outros caminhos sem tantas interdições? Que outros caminhos sem tantas sanções drásticas? Estamos falando de um romance e de

\footnotetext{
${ }^{130}$ É o caso dos discursos apologéticos escritos para a defesa feminina, em especial no que toca a questão da virtude, da honra e da bondade da mulher. Alguns são textos em verso (em quintilhas, pois tinha sido essa o forma escolhida por Baltasar Dias, cuja Malícia das mulheres, já citada em nota de rodapé do capítulo II, desencadeou polêmicas duradouras). Outros textos voltados para a defesa das mulheres saíram na forma de peças teatrais ou de cartas, estas limitadas a mais ou menos oito páginas, conforme o modelo dos papéis volantes distribuídos à altura do século XVIII em Portugal. Pouco tem sido publicado a respeito da biografia das autoras de tais discursos, o que não diminui o interesse que eles podem despertar, ao contrário, agudiza a forma como são lidos, na medida em que as respostas desejadas pelo leitor ficam circunscritas à interlocução com as folhas de papel; não há dados biográficos para completarem o raciocínio, embasando as conclusões do leitor. Gertrudes Margarida de Jesus, por exemplo, escreveu uma Primeira carta apologetica, em favor e defensa das mulheres e uma Segunda carta Apologetica, em favor, e defensa das mulheres, textos que dialogam com Espelho critico, no qual claramente se vem alguns defeitos das Mulheres, da autoria de um certo "Irmão Amador do Desengano". Não sabemos ao certo se ela foi uma religiosa, se uma esposa, se optara por um pseudônimo, apenas podemos afirmar que era dona de uma cultura elevada. Fazia citações em latim, conhecia a Bíblia, lia obras francesas publicadas na época dela e no idioma original francês. Outra autora de texto apologético, que assinava como Paula da Graça, "assistente nesta Corte”, é referida por Mário Cesariny como uma religiosa em Horta de literatura de cordel, sem elementos que nos permitam investigar a ordem religiosa, a biblioteca a que tinha acesso, a idade etc. Asseveramos que Paula da Graça era capaz de se expressar com ironia, para refutar argumentos de textos que atacavam a honra feminina. Relativamente à fortuna crítica dessa literatura, escassa como afirmamos acima, ressaltamos o papel de Ana Hatherly. Em Poesia incurável, a investigadora refere textos de outros dois autores do século XVIII, para mostrar que a repressão social era projetada no papel, graças à imaginação literária do período maneirista/barroco e à própria mudança nos valores daquela sociedade. Assinala que a "(...) no que diz respeito às mulheres, cuja honra dependeu, secularmente, do modo como empregaram o seu sexo” (p. 244).
} 
uma separação, mas mesmo se estivéssemos às voltas com o mais puro debate intelectual, o que estava guardado para uma mulher, que não caiba no incômodo que Mariana verbaliza?

Por fim, à p. 69, surgiria o tópico da liberdade. Mariana Alcoforado não trazia para o dia-a-dia dela a ferida de sentir-se inerte e limitada pela disciplina religiosa, falaria no gozo que ele, Chamilly, poderia ter, estando na França: "Bem vejo que ficarás em França, mesmo sem grandes prazeres, com inteira liberdade”. Que sabia ela sobre liberdade? Consta que foi entregue ao convento muito antes dos vinte anos. Consta igualmente que o convento recebia notícias sobre a intervenção militar e que as batalhas alteravam a rotina das freiras. Estivesse presente e atenta, era possível que refletisse, que conjecturasse. E podia lembrar da família, e podia lembrar da infância, e podia ler, podia redigir. Há numerosos exemplos de outras freiras que trocaram cartas com pessoas de fora dos seus círculos, há numerosos casos de freiras que denunciaram a violência de conduzir uma filha ao convento para resolver apuros financeiros.

\section{Três cartas de Sor Juana Inés de la Cruz}

Se mais de uma vez, nesta pesquisa de doutoramento, associamos escrita a paixão no âmbito do trabalho intelectual feminino, lembrando a análise feita pela crítica especializada em Clarice Lispector e os excessos de Sóror Mariana Alcoforado, vamos agora transcrever um fragmento extraído de Obras y apuntes, de Camila Henríquez Ureña, que viu em Sor Juana Inés de la Cruz mais uma forma de paixão: 
"Pero en mi opinión la historia de Sor Juana es la historia de una pasión y una pasión que tuvo un largo Via Crucis bajo una Cruz pesada y terminó en sacrificio y muerte. El motivo central de esa pasión fue el conocimiento."162

Sor Juana, no entanto, já recuara deliberadamente perante uma possibilidade de assumir que escrevia como apaixonada. Pelo menos na Carta atenagórica, que já contextualizamos neste capítulo e no capítulo II. Depois de recorrer ao argumento do descrédito com que as mulheres eram vistas, expressou-se da seguinte maneira: "Y para que V.md. vea cuán purificado va de toda pasión mi sentir, propongo tres razones...”163. Nas intenções declaradas ao destinatário, substituiu paixão por razão. Opção segura? Maneira adequada de contra-argumentar face ao preconceito masculino? Embora ela negasse a aparência de refutação, usando "esto no es replicar” (p. 413), acreditamos que acabou por refutar, quando acreditava melhor se explicar: "Mi asunto es defenderme con las razones de los tres Santos Padres [Augustino, Tomás e Crisóstomo]” (p. 413). Terá sido, no entanto, uma concretização, para além de um roteiro discursivo?

Acompanhar a argumentação de Sor Juana permite verificar o que se seguiu à afirmação da razão. Sendo assim, damos com a sucinta e contudo elogiosa apresentação que ela fez do Pe. António Vieira, na qual procurava salientar o empenho e ao mesmo tempo o ímpeto do religioso português. Não sem cuidado, Sor Juana sublinhou também a potência do entendimento humano, para com ela autorizar sua discordância e, então, começar a exposição

\footnotetext{
${ }^{162}$ Camila Henríquez UREÑA, Obras y apuntes, 2006, p. 170. Fragmento que conversa com esse está em Octavio PAZ, Sor Juana Inés de la Cruz o las trampas de la fe, 2003, p. 515: "Vana sutileza y ingenio vacío pues no estaban aplicados a ningún objeto real sino a entelequias alejadas de la verdadera filosofía. Pasión retórica, enamorada de sí misma y lejos también del auténtico sentimiento religioso: shadow boxing" (o grifo é nosso). Ele se referia ao Padre António Vieira e a Sor Juana.

${ }^{163}$ Sor Juana Inés de la CRUZ, Obras completas de Sor Juana Inés de la Cruz, IV, Comedias, sainetes y prosa, 2004, p. 412.
} 
propriamente dita.

Anunciados os santos que o Pe. Vieira tinha contestado, ela foi enumerando provas da sua leitura das finezas de Cristo. A explanação é clara, pois obedecia a um esquema: de Vieira ao santo e do santo a ela, com citações em latim intercaladas. Quando resumia, Sor Juana avisava; quando sentenciava, repetia uma fórmula (“Luego fue mayor fineza ausentarse que morir”, p. 415; “”'Luego es, por ambos términos, la mayor fineza morir”, p. 416; "Luego fue mayor fineza el morir”, p. 417; “Luego la mayor es morir”, p. 417). Quando foi possível, criticou o método do Pe. António Vieira: “¿Qué forma de arguir es ésta? El Santo propone en género; el autor responde en espécie. Luego no vale el argumento” (p. 412). E quando a paixão pelo conhecimento deve ter assomado, exclamou: “¡Válgame Dios! ¿Pudo pasarle por el pensamiento al divino Crisóstomo, que Cristo obró tal cosa sin causa, y muy grande?” (p. 422) ${ }^{164}$. Chegado o ponto em que julgava ter atingido a falha do Pe. Vieira, Sor Juana foi mais dura: “Claro está que el autor sabrá esto mejor que yo, sino que quiso hacer ostentación de su ingenio...” (p. 425). Esgotado esse esclarecimento, passou a antecipar os argumentos que o destinatário encontraria para refutar os dela, fazendo-o por mais de uma vez, à p. 428 e à $431^{165}$. Enfim, resumiu suas próprias idéias ao final da p. 423, para passar às fórmulas de humildade (p. 434) e ao reforço, muito bem feito, do argumento do preconceito com as mulheres:

\footnotetext{
${ }^{164}$ Mesmo ânimo para com a análise Sor Juana demonstraria em outro trecho: “A mi parecer el autor anduvo muy cerca de este punto, pero equivocólo y dijo lo contrario" (p. 430). O comentário nos transmitiu uma agilidade própria de quem está envolvida com um assunto, podendo o envolvimento advir de paixão pelo tema, da paixão pelo ato de analisar, da paixão pelo diálogo.

${ }^{165}$ Vale a pena assinalar uma outra impressão de leitura: Sor Juana esperaria encontrar mais leitores além de Manuel Fernández de Santa Cruz? Pois se em alguns momentos dirigiu-se a ele ("V.md. los podrá leer despacio en el mismo autor a que me refiero...”, p. 415; "Unos corregirá com discreción y otros suplirá com su amistad”, p. 434), em outros parecia falar com eventuais destinatários ("Podránme replicar”, p. 428; "Pudiéranme, ahora, replicar”, p. 431). Como a carta é privada, palavra que a própria Sor Juana utilizou à p. 435, pode ser que ela tenha remetido a um destinatário, mas tendo em mente o diálogo com um grupo mais largo.
} 
“(...) no es ligero castigo a quien creyó que no habría hombre que se atreviese a responderle, ver que se atreve una mujer ignorante, en quien es tan ajeno este género de estúdio, y tan distante de su sexo” (p. 435). As últimas quatro páginas da Carta atenagórica, Sor Juana ocupou com um discurso sobre outro tipo de finezas, que ela preferiu separar das finezas do fim da vida de Cristo. Diante das sutilezas que ela captou - muito provavelmente porque leu com atenção os textos de Augustino, Tomás e Crisóstomo - e da argúcia na disposição, que compreende essa separação bem pensada, podemos imaginar o trunfo que oferecia obedientemente a Manuel Fernández de Santa Cruz e o quanto pode têlo irritado com a fluência, o à vontade e a inteligência.

Quanto ao desenvolvimento do conteúdo, Sor Juana já foi lida com reserva e já foi elogiada. Sabendo que ela está no cânone do México, vamos discutir apenas um dos casos de ressalva, o do monge beneditino espanhol Benito Jerónimo Feijoo. Sua “Defensa de las mujeres” sairia em Espanha no ano de 1726, com um tópico dedicado ao comentário das qualidades de Sor Juana como poeta; ele aproveitava para frisar que a agudeza pela qual ela fora famosa não a elevara ao patamar do Pe. Vieira. Interessante é ele ter assinalado que “faltóle energía” ”: o que significaria energia no século XVIII, saído da crítica de um religioso, sobretudo após o reconhecimento de que Sor Juana tinha “naturalidad”? ${ }^{166}$ A seguinte observação de Octavio Paz pode ser considerada

\footnotetext{
${ }^{166}$ Benito Jerónimo FEIJOO MONTENEGRO, "Defensa de las mujeres”, 1736, p. 26. O que se pode depreender do uso da palavra "energia", na falta de proximidade com a época? No §. XXIV, prestes a concluir o raciocínio, o monge levantou algumas questões sobre o direito feminino ao conhecimento, avisando que se tratava de antecipar um reparo que o leitor podia pôr ao texto dele. Segundo ele, ninguém deveria supor que há prejuízo em a mulher conhecer melhor o mundo e a sua própria natureza. Conhecer na acepção que mais vale a pena explorar - quer dizer chegar à verdade; se a mulher almeja agir corretamente, irá em busca da verdade, que tem um valor intrínseco. E quando o homem, por vício, sustentar que tem um entendimento superior ao dela, sem o ter, que as capacidades femininas dêem à mulher auto-confiança. É o que o monge tenta ensinar com a "Defensa de las mujeres". Algumas mulheres, como Gertrudes Margarida de Jesus, autora portuguesa já mencionada nesta tese, não só leram
} 
como uma pista para entendermos a citação: “El caso de sor Juana se há repetido una vez y outra vez: há sido una nota constante de la cultura española e hispanoamericana hasta nuestros dias. De siglo en siglo un Feijoo, un Sarmiento o un Ortega y Gasset intentan ponernos al dia”167. Tão empenhado quanto a própria Sor Juana, o monge Benito Feijoo pode ter exigido dela qualidades que sequer deixou claras. Estaria cobrando dela alguma espécie de força bem aplicada? Consultamos obra de D’Alembert e Diderot uma vez que, à altura de Feijoo, foram responsáveis por uma forma nova de catalogação do conhecimento ${ }^{168}$. Num texto dedicado ao esclarecimento da filosofia do próprio enciclopedismo, Diderot aludiu à energia que todo ser humano tem para estudar e trabalhar, utilizando o termo no sentido de "potência”. Um colaborador de Diderot, o cavaleiro Louis de Jaucourt, empregou o termo “energia” num verbete da área da linguagem, para caracterizar um tipo de linguagem. Em outro verbete, o mesmo colaborador explicou a poesia lírica passando pelo termo “energia”; mostrou que certos estados, certos picos de muita energia se convertem no sublime da poesia. Por fim, encontramos em Edme-François Mallet e André Morellet, outros dois colaboradores da Encyclopédie, um uso do termo “energia” no sentido de veemência. O texto dos dois autores versava sobre Teologia, incluindo Santo Augustinho. É significativo que eles critiquem com critérios claros a ênfase das explicações do santo para determinadas passagens bíblicas; ele não as havia entendido da melhor forma, por não conhecer a fundo o hebraico, mas enveredara por explicações do sentido figurado que julgava ter

\footnotetext{
o monge Benito Feijoo, como utlizaram algumas citações dele em textos com que defendiam pontos de vista femininos.

${ }^{167}$ Octavio PAZ, Sor Juana Inés de la Cruz o las trampas de la fe, 2003, p. 340.

${ }^{168}$ Os volumes da Encyclopédie que consultamos foram publicados ou no ano de 1755 (v. 5), ou no de 1756 (v. 6) ou no de 1765 (v. 9 e v. 12), distantes da publicação e do universo de Feijoo em vinte ou em trinta anos, portanto.
} 
descortinado. Segundo Edme-François e André, a força ou a energia que ele julgou ter percebido no Antigo Testamento não passava de um sentido literal assumido como sentido figurado. Benito Feijoo estaria a contar com uma Sor Juana tão evasiva e, ao mesmo tempo, tão categórica quanto Santo Augustinho? Embora na Carta atenagórica ela se tenha posto ao lado desse santo, para divergir da interpretação de Vieira, pode ter parecido leitora menos competente do que ele, aos olhos de Benito Feijoo. Daí que ele afirme que faltava energia a ela.

Já a Respuesta a Sor Filotea, que só foi publicada em 1700, teve como resultado o silêncio do destinatário. Mas de que matérias tratava, para redundar em silêncio? De matérias irrefutáveis ou de matérias irrelevantes? Ou seria a forma do discurso a causadora do silêncio? No princípio da carta, Sor Juana escrevera sobre a responsabilidade, sobre o saber responder à carta de Sor Filotea. Agradecia o excessivo favor que tinha recebido, isto é, agradecia pela publicação da Carta atenagórica. De posse das informações que temos hoje, como passar ingenuamente pelo agradecimento? Sor Juana seria repreendida e teria de abjurar por causa da discordância quanto às interpretações do Pe. António Vieira. O que ela teria imaginado como desdobramento da leitura da Carta atenagórica? De acordo com a percepção dela, teria saído fortalecido um canal de comunicação entre Manuel Fernández de Santa Cruz e ela? Os habituais admiradores iriam aderir à sede de conhecimento, que afinal era um traço dela? Seja como for, ela agradeceu e mais perto do fim da carta deu a entender que sabia do "crimen" de que a Carta atenagórica seria acusada e do que o censor tinha dito; expressar gratidão levou-a a elencar situações nas quais se via a surpresa, a confusão e a vergonha de quem recebera uma graça. Para as 
personagens bíblicas elencadas, depois dos sentimentos desconcertantes vinha justamente a gratidão, sentimento que ela procurava externar com a enunciação em $1^{a}$ pessoa. Ao fim desse preâmbulo, que Sor Juana chamou “digresión”, foi iniciada uma parte da carta destinada a explicações muito delicadas, talvez mais delicadas do que o tema da Carta atenagórica. Sor Juana escolheu termos fortes para justificar a dedicação à escrita de textos profanos: "temor”, "horror", “repugnância”, algumas vezes repetidos. Ela levantava a questão da insistência alheia - causadora de receios -, no mesmo texto em que encararia com certa negligência o perigo que o tribunal do Santo Ofício representava: “(...) una herejía contra el arte no la castiga el Santo Oficio, sino los discretos con risa y los críticos con censura” (p. 444). Parecia instável ou ainda presa ao estado de confusão que referira no preâmbulo. Muito concentrada em discorrer sobre a inclinação para as letras ("Prosiguiendo en la narración de mi inclinación, de que os quiero dar entera noticia...”, p. 445), passou por episódios perturbadores: o corte de cabelo associado ao ritmo da aprendizagem de conteúdos caros a ela; o desgosto que um casamento lhe teria trazido; a frustração que o aprendizado sem mestres representara em outros tempos etc. Deu a conhecer, também, alguns ensinamentos que a leitura dos poemas podia revelar ao leitor, como por exemplo os esquemas concebidos por Kircher. Penetrante, Sor Juana mostrou que não só era invejada como invejava, porque a ela o desejo de saber custara, antes mesmo que o saber em si demonstrasse o preço que tinha. Era uma acusação mesclada a tantas confissões. Pela matéria e pelo modo pode ter predisposto Manuel Fernández de Santa Cruz a condená-la. Já se atrevera a interpretar um sermão, agora repartia as dores que as regras alheias a fizeram sentir. As acusações, aliás, intensificar-se-iam no texto, porque ela escreveria 
contra as perseguições, mesmo as bem-intencionadas.

Mais interessante nos parece, todavia, o que ela afirmaria à p. 458. A paixão que Sor Juana nutria pelo conhecimento não estava presa numa carta como esta, embora subsistisse nessa e noutras cartas, não se restringia aos exercícios poéticos e às conversas que sem dúvida vinham deixando forte impressão nos interlocutores de Sor Juana; a paixão pelo conhecimento era reavivada a cada dia, porque com apaixonada curiosidade pelo conhecimento Sor Juana se relacionava com o mundo, era por obra dessa paixão que se aproximava das pessoas e dos eventos: "Este modo de reparos en todo me sucedía y sucede siempre, sin tener yo arbítrio en ello, que antes me suelo enfadar porque me cansa la cabeza; y yo creia que a todos sucedía esto mismo y el hacer versos, hasta que la experiencia me ha mostrado lo contrario...”. Sor Juana chamava essa paixão de vício, depois dizia que era loucura, mas a narrativa a afirmava como instrumento. E, depois de algumas voltas, ela insistiria, prosseguindo assim até o fim da carta, na questão do que podia ser o conhecimento no universo das mulheres e do porquê de não as repreender.

La carta, texto destinado a Antonio Núñez de Miranda em data não indicada, parece uma estratégia empregada com direção segura. Sor Juana assumira como princípio o direito a redarguir, e além disso dissera que o fazia como uma discípula podia fazer, mas não como uma crente em Deus. Desde o começo pusera em evidência o fato de conhecer o aborrecimento do confessor e a esse estado associava o seu próprio silêncio. O raciocínio não deixa de ser interessante, porque o silêncio já fora tantas vezes um argumento dos homens, numa tentativa de atacar a propalada tagarelice feminina. A mulher, segundo Ovídio, por exemplo, era dona de um discurso merecedor de pouco crédito, pois 
ela costumava ser repetitiva. Outros homens, em outras épocas, defenderam que a mulher devia falar quanto tivesse coisas úteis a dizer, porque assim estaria a evitar a tagarelice. Mas Sor Juana pensava ver no seu próprio silêncio e na sua paciência afrontas aos homens com quem estava mais habituada ou a debater ou a contrariar. Seria dedução abusiva, presunção? Ou ela sentir-se-ia estranha ao agir de maneira mais feminina, isto é, ao agir em conformidade com a passividade e a receptividade que muitas vezes caracterizam as mulheres? ${ }^{169}$ Desconfortável diante da alternativa que escolhera ou lúcida quanto à recepção de Núñez de Miranda, Sor Juana inverteria a situação; passaria a perguntas retóricas que soam agressivas: “Ahora quisiera yo que V.R. com su clarísimo juicio se pusiera en mi lugar y consultara ¿ qué respondiera en este lance? $\dot{\imath}$ Respondería que no podia? Era mentira. ¿ Que no queria? Era inobediencia. ¿̇ Que no sabia? Ellos no pedían más que hasta donde supiese? ¿ Que estaba mal

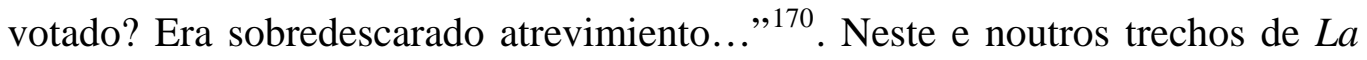
carta, Sor Juana é explícita, dura, inverte questões que eram feitas para pôr a vontade e a determinação das mulheres à prova, chegando a repreender Antonio Núñez pelo modo como tentava forçá-la a mudar de comportamento. Sem dúvida que ela, ao apelar com tanta veemência para o cessar do martírio que estava vivendo, terá dado mais uma confirmação da sua convicção e da sua assertividade. Não seria de todo incorreto dizer que da leitura dessa carta saímos a enxergar a relação entre eles em termos da autoridade de um versus o empenho

\footnotetext{
${ }^{169}$ Camila Henríquez UREÑA, leitora da obra de Sor Juana, já fez uma apreciação da condição feminina que interessa resgatar a propósito do desconforto que a novo-hispana pode ter sentido. Segundo ela, enquanto a mulher estiver mentalizada para a forma masculina de se afirmar em sociedade, pode ser que ela tenha muita dificuldade para encontrar a própria afirmação, quer dizer, pode ser que ela não reconheça o seu espaço de mobilidade, de intercâmbio, o seu repositório de energia vital. A partir do momento em que assumir o universo doméstico como referência central, de onde derivam as primeiras oportunidades de obter satisfação e sucesso, terá o trânsito facilitado, os pesos mais equilibrados na busca de afirmação e o próprio modelo traçado.

${ }^{170}$ Octavio PAZ, Sor Juana Inés de la Cruz o las trampas de la fe, 2003, p. 640.
} 
de outro. Sor Juana fora vigorosa. 


\title{
CaP. V - A RePercussão do Legado
}

\author{
"Só mostro que compreendi um escritor \\ se conseguir agir de acordo com o seu espírito, \\ se conseguir, sem reduzir a sua individualidade, \\ traduzi-lo e transformá-lo de muitas formas."
}

Novalis

No contato com cada obra literária, o leitor apaixonado ronda a liberdade de detectar e de enraizar e, nesse movimento, pode ser que emerjam valores pessoais. Enquanto lê e faz a escrita de si, o leitor apaixonado potencializa as chances de identificação e de estabelecimento de um encontro legítimo e profundo com o outro. Se opera nele, no tempo da leitura, um encanto qualquer que o absorve inteiro para a decifração do texto, então ele se torna responsável ou por uma mensagem ou por um arranjo linguístico ou por ambos os eixos do trabalho do escritor. Responsável, entra na dimensão do responder a. Passa a ter um certo tipo de prontidão para tudo o que a obra gera nele. Imaginemos que esse leitor é, ele mesmo, um artista. Estamos diante da possibilidade de uma repercussão criativa. Não é mais um amigo que conta a outro amigo o que descobriu nas páginas de um livro, não são dois ou três familiares a discutirem o êxito de uma imagem conseguida por um escritor. Passa a ser a vez - a voz - do artista capturado pela palavra do outro.

Porque entendemos nesta tese de doutoramento que o material legado por Sóror Mariana Alcoforado e Sor Juana Inés de la Cruz foram pontos altos respectivamente na epistolografia e na poesia do século XVII, porque defendemos que têm poder para congregar admiradores, reunimos o trabalho de alguns artistas que vêm propagando a obra da freira portuguesa e a da novo- 
hispana. Vamos comentá-lo neste último capítulo da pesquisa, a fim de uma vez mais confirmar a representatividade contida nesses dois exemplos de criação feminina. Os textos de apresentação e análise estão divididos em cinco partes, nas quais há seis trabalhos em exame. Sóror Mariana Alcoforado vem sendo resgatada e é este resgate que nos interessa; Sor Juana Inés de la Cruz vem sendo relida, pois já tem lugar garantido na sua cultura, já pertence a um conjunto. Vamos aludir a poucos casos de releitura do exemplo e da obra dela, sem ceder à tentação de referir e comentar cada objeto cultural inspirado nesse ícone.

\section{Yo, la peor de todas}

Os créditos exibidos antes da trama já cuidavam de estabelecer uma associação entre Yo, la peor de todas e a obra de crítica literária Sor Juana Inés de la Cruz o las trampas de la fe. A propensão à análise conjuntural do século XVII novo-hispano não poderia ser de fato mais evidente no filme de Maria Luisa Bemberg, paralelamente à abordagem da personalidade de Sor Juana. A primeira cena se incumbiria de exibir uma conversa tensa entre o arcebispo Francisco Aguiar y Seijas e o Vice-rei Tomás Antonio de la Cerda, marquês de Laguna; a salvação da Nova Espanha seria então evocada como pretexto para as antipatias, as intrigas e as disputas de poder. Nem as brincadeiras entre as jerônimas, objeto da cena seguinte, desviariam a atenção do espectador por muito tempo. Porque à atividade no pátio do convento de Santa Paula seria contraposto o ritmo próprio da cela de Sor Juana: a lira, o relógio, o espelho e todos os muitos instrumentos, enfim, estavam à sua mão, ela sentava-se à mesa para estudar, mesmo que o farfalhar a incomodasse. Logo em seguida, confrontados, os dois mundos mostrariam sua incompatibilidade; ao anúncio de 
que Sor Juana fora escolhida pelo vice-rei para uma primeira aproximação do círculo político ao círculo religioso, muitas religiosas reagiriam mal. “Apasionada”, “irónica”, assim Sor Juana seria introduzida na ação do filme argentino pelas palavras do mesmo vice-rei, no decorrer da visita que a abadessa anunciara; representada na sua beleza e no seu sentido de oportunidade, teria ocasião para falar da preferência pelo silêncio dos livros e pela solidão; pronunciar-se-ia quanto à censura feita a eles por Antonio Núñez de Miranda e quanto ao matrimônio, sempre na companhia de Maria Luisa, a marquesa de Laguna. Como Octavio Paz não tratara especificamente da marquesa, embora a mencionasse em muitas páginas (mais de setenta), não podemos afirmar que ela tenha questionado Sor Juana acerca da maternidade, por exemplo, a exemplo do que ocorre em uma das cenas do filme. Também não sabemos se Sor Juana teria realmente discordado da observação de Maria Luisa sobre o mundo de ambas ser pequeno. Parece apropriado que o filme tenha colocado na resposta de Sor Juana quatro versos feitos para homenagear outra mulher, a Condessa de Galve: "Para el alma no hay encierro / ni prisiones que la impidan, / porque solo la aprisionan / las que se forma ella misma”171. Teria construído sua prisão? Falaria mais alto a alma, vivendo a mulher nessa prisão, já acostumada à dificuldade? Seria infeliz, afinal? Na conversa entre as duas mulheres, viria à tona a idéia de tristeza, que Sor Juana rejeitaria; por outro lado, ela própria diria que a vida dela envolvia uma escolha pelo caminho áspero e sem doçuras. Na cena seguinte, a leitura dos primeiros oito versos da redondilha de número 84 ("Este amoroso tormento / que en mi corazón se ve, / sé que lo siento, y no sé / la causa porque lo siento. / Siento una grave agonía / por lograr un devaneo, / que empieza como

\footnotetext{
${ }^{171}$ Sor Juana Inés de la CRUZ, Obras completas de Sor Juana Inés de la Cruz, II, 2004, p. 120.
} 
deseo / y pára en melancolia” ${ }^{172}$ ) ofereceria ao espectador possibilidade de aprofundar a compreensão do tema, além de aludir - como muitas cenas fariam - aos sentimentos e às emoções despertadas por Sor Juana na Marquesa de Paredes e pela Marquesa em Sor Juana. O filme insistirá na sensualidade que não estaria patente só no papel, havendo cenas com trocas de carícias, com declarações inequívocas, com demonstrações de repúdio à relação por parte da Igreja e de ciúmes por parte do Marquês. A frontalidade de Sor Juana, sendo o tema o amor ou a Teologia, não importa, ficará marcada em muitas mais cenas; como no caso do atrito com o arcebispo. Referências à Carta atenagórica, aos livros confiscados, ao retorno dos marqueses de Paredes à Espanha, aos tormentos causados pela enfermidade etc, o filme acompanharia o percurso de Sor Juana até a morte, sem nunca abandonar o paralelismo entre o plano político e o pessoal.

\section{Desventurado amor e Mariana}

Um dos volumes contemplados neste capítulo dedicado à apreciação de alguns herdeiros de Mariana Alcoforado e de Juana Inés de la Cruz é Desventurado amor, livro de Ruy Chianca, autor português praticamente desconhecido do público atual.

Esse romance histórico de 195 páginas distribuídas em 17 capítulos foi publicado no ano de 1916, altura em que a recepção da figura de Mariana Alcoforado e do envolvimento amoroso supostamente mantido por ela com um oficial francês ainda eram beneficiados pelo enquadramento numa aura de

\footnotetext{
${ }^{172}$ Sor Juana Inés de la CRUZ, Obras completas de Sor Juana Inés de la Cruz, I, 2004, p. 213.
} 
sentimentalismo romântico e de intensidade. Tais qualidades valorizavam a obra literária e, inclusive, torná-la-iam uma espécie de “vinha muito vindimada”173.

Ao nível das etiquetas que elas receberam, por assim dizer, é interessante referir outro prefácio, para outra edição das mesmas Cartas portuguesas $^{174}$ : Nuno de Figueiredo salientou períodos anteriores a 1916 e também um período quase coincidente com o início do século $\mathrm{XX}$, ao nomear defensores da autenticidade alcoforadista, porque admiradores da beleza das cinco cartas atribuídas à freira. Mencionou, entre outros, Stendhal, Rainer Maria Rilke, Camilo Castelo Branco e Jaime Cortesão. Fiquemos com o sentido atribuído ao livro pelos autores de língua francesa e alemã. O primeiro havia lançado, em 1822, um livro sobre o amor e citara o caso de Mariana, de forma a realçá-lo positivamente ${ }^{175}$; o segundo, de acordo com texto introdutório de Paulo Quintela ${ }^{176}$, refletia profundamente acerca da morte e do amor, por ocasião da escrita das suas dez célebres elegias e concluiu que as mulheres é que sabiam amar - entre elas Rilke destacara a religiosa de Beja.

Nesta atmosfera de exaltação e de reverente acolhimento, portanto, foi lançado o livro Desventurado amor. Podemos compreender o entusiasmo do autor que, em parte, resvalou para soluções de pouco brilhantismo, na tentativa de contar a história de amor vivida pelo casal Mariana Alcoforado e Chamilly.

\footnotetext{
${ }^{173}$ Utilizamos expressão de Eugénio de Andrade usada em texto curto, à guisa de prefácio para as Cartas portuguesas ${ }^{173}$, que ele traduziu em 1969.

${ }^{174}$ Mariana ALCOFORADO, Cartas portuguesas, 1974.

${ }^{175}$ No artigo "Imagination and Memory in Stendhal" (originalmente escrito para Diogenes, Unesco, 201, 2004 e disponibilizado em http://www.renatojanine.pro.br/LEstrangeira/stendhal.html), o professor titular de Ética e Filosofia Política na Universidade de São Paulo, Renato Janine Ribeiro, situou o escritor Stendhal numa corrente de pensadores que transformaram consideravelmente a noção grega de pathos e a de amor. O "passionate love” era então uma novidade na passagem do século XVIII para o XIX e tornouse por obra de determinadas publicações no "supreme love", contrariando a idéia de que as inclinações dos desejos tinham de ser forçosamente controladas pela ação da vontade e da razão. É nesta conjuntura de forças que o contributo de Mariana Alcoforado é recebido de braços abertos, como testemunho dos mais profundos aspectos da alma.

${ }^{176}$ Rainer Maria RILKE, As elegias de Duíno e Sonetos a Orfeu, 1968, p. 28.
} 
Um pequeno paralelo pode ajudar a ponderar, a abrir um parêntesis elucidativo: uma retomada da obra Cartas portuguesas dentro do gênero romance histórico levada a cabo na década de 90 do século XX pela descendente de portugueses Katherine $\mathrm{Vaz}^{177}$ é, no tocante às saídas para expressar os tão vívidos afetos de Mariana Alcoforado, muito semelhante em termos de êxito ao resultado de Ruy Chianca, ou seja, afastou-se pouco da valorização do modelo de mulher inteiramente dedicada ao amor e às relações pessoais movidas em nome de um sentimento autêntico. Mais a respeito desse outro livro, entretanto, teremos oportunidade de conhecer adiante, neste mesmo capítulo.

Voltando à questão da quantidade de dados disponíveis para interpretar o romance de 1916, afirmamos que pouca notícia foi encontrada, quando procuramos traçar um esboço da biografia de Ruy Chianca. Em consulta ao Diccionario Bibliographico Portuguez ${ }^{178}$, na sua versão informatizada, constatamos que não existia alusão ao escritor. O mesmo aconteceu quando recorremos ao Dicionário de Literatura ${ }^{179}$ organizado por Jacinto Prado Coelho. No entanto O Romance Histórico em Portugal ${ }^{180}$, de Maria de Fátima Marinho, ofereceu-nos três pequenos blocos de informação às páginas 124, 315 e 330 . O primeiro deles contém breve resumo da obra de que tratamos e um comentário acerca do tipo de heroína presente na narrativa, ao passo que os dois seguintes são respectivamente o apontamento do nome do romance, em função da cronologia das publicações do gênero em Portugal, e a indicação bibliográfica completa da obra citada à página 124. Existem mais elementos no Dicionário de

\footnotetext{
${ }^{177}$ Katherine VAZ, Mariana, 1999.

${ }^{178}$ Innocencio Francisco da SILVA e BRITO ARANHA, Diccionario bibliographico portuguez, 2001.

${ }^{179}$ Jacinto do Prado COELHO, Dicionário de literatura, 1994.

${ }^{180}$ Maria de Fátima MARINHO, O romance histórico em Portugal, 1999.
} 
Literatura Portuguesa ${ }^{181}$ : o autor nasceu em 1891 e faleceu em 1931, teve certo sucesso como dramaturgo no princípio do século XX e é reconhecido como neoromântico.

Fiquemos, portanto, com o que a leitura em si tem a oferecer para análise.

Há marcas textuais ao longo de todo o livro que criam uma ligação entre o narrador e a leitora, de forma a cativá-la. As mais polidas estão localizadas no começo do livro, para firmar um contrato ou protocolo de leitura. Às vezes são apenas vocativos. De qualquer forma, a estratégia discursiva representa meio de enunciar e, assim, configurar o tipo de destinatário do livro analisado. Eis alguns casos: 1) p. 7: "Não se agonise a leitora”; "leitora gentil”; 2) p. 8: "Senhoras”; 3) p. 13: "Senhoras minhas!... folgae agora”; "Entrae commigo a dentro do mosteiro"; 4) p. 27: "Senhoras! Deitae as culpas às manhas do tentador, anjo infernal ou creatura humana. E ponto na arenga!...”; 5) p. 113: "Esticae as rédeas da phantasia, senhoras minhas, e não despenheis no inferno, tão futilmente condemnada ao horror das penas eternas, uma alma que tenho a certeza - vae dos bicos do meu aparo direitinha para o céu!”; 6) p. 138: “O resto, senhoras minhas, é velho e feio”; 7) pp. 144-145: “Adivinha-o melhor do que eu lh'o posso explicar o espírito subtil da leitora”; 8) p. 149: "Mas naturalmente - a leitora perdoa a verdade inconveniente do advérbio...”182.

Registramos a insistência no uso do substantivo feminino “senhoras”, pois evidencia a consciência de Ruy Chianca. Ele saberia que estava compondo uma história mais interessante para as mulheres do que para os homens, por isso utilizou muitos adjetivos, empregou exclamações, sugeriu que as senhoras

\footnotetext{
${ }^{181}$ Álvaro Manuel MACHADO, Dicionário de literatura portuguesa, 1996.

${ }^{182}$ Mantivemos a ortografia da época, para não fazermos adaptações que não se justificam. São exemplos citados fielmente.
} 
teriam faculdades facilitadoras de uma leitura atenta das obras literárias. Ainda expressou a crença na boa direção das senhoras, isto é, no benefício que elas teriam ao buscar determinados livros, como se livros bons refletissm o caráter dessas mulheres. $\mathrm{O}$ autor conduziu as leitoras e as protegeu do sofrimento neste movimento, ao mesmo tempo em que lidou com a antiga noção de ensinar e deleitar. Com respeito a este último ponto, o ensinar e deleitar, vale a pena verificarmos que em teoria este traço dos romances históricos é de fato tido em consideração em alguns estudos: “o género surge na linha nacionalista e pedagógica”"183.

Algumas vezes o narrador, mesmo que não utilizasse termos como os expostos na lista numerada, desenhou com outras palavras o modelo de leitora que buscava, a fim de instaurar cumplicidade:

"Não é causa portanto a vaporisar miasmas o livro que d'ella [Sóror Mariana] se occupe. Nem, apoz a sua leitura, ficarão nas almas rastos ardentes de pés cabruns, de que se conclua ter-se o autor conloiado com o anjo das trevas para levar o veneno ao seio das famílias" (p. 8, grifo nosso).

Também à p. 105 isto aconteceu: "E o nosso velho Thomé? Tem-nos andado longe da penna; e quantas penas tem soffrido?”. O fragmento é interessante por conter os pronomes "nosso" e "nos" e além disto apostar num jogo de palavras com o vocábulo “penna”. O narrador refletia de maneira muito ligeira sobre o ato de narrar e ao mesmo tempo fazia um gracejo que podia conquistar a simpatia de uma leitora entregue ao prazer da leitura. Finalmente, à p. 108: "Nós, todos nós conhecemos isto [contrastes na vida]", como se o narrador partilhasse com a leitora a tarefa de ler o mundo.

${ }^{183}$ Maria de Fátima MARINHO, O romance histórico em Portugal, 1999, p. 305. 
O único ponto da narrativa em que a focalização se altera é o capítulo XVI, em que estão reproduzidos pedaços das cartas atribuídas a Mariana Alcoforado. No restante da obra, o narrador não participa da história narrada. Mesmo sem tomar parte, esteve próximo do leitor, isto é, reforçou frequentemente o elo entre eles; tinha até uma tese (que para nós estar disposta já à p. 15 do livro e à qual voltaremos) que, para ser demonstrada e comprovada, não demandou da parte do narrador muitos esforços, no sentido de um aprofundamento na psicologia das personagens.

Logo à primeira página do livro está a ser explorada a polêmica da verdade no romance histórico: "não hei-de forçar a imaginação para, torcendo a verdade...”. Mesmo que breve, a alusão confirma a importância que o conceito de verdade tem para a construção de um romance histórico, pois trata-se de gênero híbrido, mistura de ficcionalidade e verdade, ambíguo por isto mesmo, dependente da fantasia e da concretude. Os nomes de figuras históricas que o autor elencou podem nos auxiliar no tocante a esta questão da verdade: D. Affonso VI, Conde de Castelo Melhor, Marquês de Marialva, D. Sancho Manuel, D. João d'Austria, Luiz XIV, D. Maria Francisca de Saboia, Felipe IV de Espanha, Matias de Albuquerque, conde de Cantanhede, conde de Soure, conde de Schomberg, D. Francisco e D. Beatriz (duques de Beja), D. Duarte, D. Manuel, D. Luiza de Gusmão, D. Pedro, Carlos II e Marianna d'Austria. À p. 9 é apontado o Tratado dos Pirineus, à 10 e à 11, as batalhas do Ameixial (1663) e de Montes Claros (1665); somos remetidos aos espaços de Évora, Assumar, Ouguela, Veiros, Monforte, Crato, Borba e Figueira para, após uma interrupção brusca deste relato de cariz histórico, à altura da p. 12 mais especificamente, o espaço português ser redimensionado pelos contornos da janela de Mértola, 
referência imortalizada ${ }^{184}$. Interessante é também um julgamento em meio à enumeração a que procedemos acima, porque deste modo o livro saía fortalecido em termos de realismo e de credibilidade: segundo o narrador, todo monarca que se afastava dos negócios de Estado não merecia complacência. O que no enredo confirmava este raciocínio era o comportamento de Felipe IV de Espanha.

Mediante a indicação dos duques de Beja (fundadores de conventos na cidade) e a menção a Nossa Senhora da Conceição, sobressaía a componente religiosa da identidade nacional, resgatada pelo romance histórico. Isto para não falar na Inquisição (de Évora), várias vezes lembrada. Hábitos associáveis à moral cristã apareciam no livro, como podemos ler em: “O velho serão portuguez!” Pouca maledicência e uma grande paz nas almas” (p. 98).

Enfim, se o romance não alcançava uma "ressurreição poética dos seres humanos” ${ }^{185}$, pelo menos criava, em mais de três páginas consecutivas no início da narrativa, uma teia de dados palpáveis e fiáveis para dar relevo à História, no tempo e no espaço.

Podemos asseverar que o autor estabeleceu associação clara entre o destino do país e o das personagens: "Em má hora entrava em Lisboa Francisco Alcoforado. Boa seria ella para os seus desígnios; mas terrível para os destinos do paiz; mas vergonhosa para o prestigio da coroa” (p. 153).

Durante a leitura, damos com a importante questão da datação no seguinte trecho:

\footnotetext{
${ }^{184}$ A título de confirmação do interesse pelo suporte físico, lembramos que o site do Museu Regional de Beja (Museu Rainha D. Leonor) mantém online desde há pelo menos dois anos uma imagem da famosa janela em sua situação atual. Tal imagem está acessível a partir de um link com os seguintes dizeres: “ $O$ Museu conserva ainda a grande janela gradeada, mais conhecida como a Janela de Mértola, das Portas de Mértola ou de Mariana, verdadeiro ex-libris do convento, do museu e da cidade, através da qual a religiosa viu tantas vezes passar aquele que a encantava e que num dia especial a destacou com o seu olhar $e$ lhe fez sentir os primeiros efeitos da sua infeliz paixão". (http://www.museuregionaldebeja.net/sorormarianaalcoforado.htm).

${ }^{185}$ Maria de Fátima MARINHO, O romance histórico em Portugal, 1999, p. 22.
} 
"Terminada a parlenda, vinde commigo, senhoras, pelos séculos dentro até esse anno de 1666, em que se acresceu de trabalhos a vida de nossa terra e em que se trasmalhou do rebanho divino uma pobre mulher que a estouvice humana acorrentou ao claustro, quando o sopro de Deus a impelia para o amor do mundo e dos homens feitos á sua imagem e semelhança" (p. 8).

O excerto revela que o autor reservara lugar tanto para a História quanto para a individualidade. E ambas as vertentes estão indicadas como indispensáveis ao romance histórico. Não podemos assegurar, todavia, que o livro em análise tenha conseguido transcender os acontecimentos reais que referia nem que nele existia consciência dos grandes movimentos históricosociais.

Katherine Vaz, por seu turno, não só indicou locais e datas, como pôs Mariana e outras personagens a refletirem sobre a mentalidade dos espanhóis (a p. 40 trouxe um raciocínio interessante sobre a linguagem de um e de outro povo), as circunstâncias da guerra (“O teu pai diz que o convento é um lugar seguro em tempo de guerra”, p. 49), a situação em que uma instituição como o convento era posta em função da guerra (“As freiras franciscanas do Convento da Conceição não permaneciam atrás das grades, mas passeavam-se pelo locutório. E uma data de soldados iam à cozinha buscar comida e bebida”, p. 77). Também apontou batalhas (p. 115), tratados (p. 176) e a sobrevalorização dos oficiais franceses (p. 194)

O tom do princípio da narrativa de Ruy Chianca é pomposo, grandiloquente (“Dezenas de intróitos bem alfaiados de campanudo estilo se me antolharam ao pegar da pena”, p.7), justamente quando o autor queria convencer de que não se importava de escrever em outro registro. Ele mencionara a crítica (“E agora caia sobre mim o terrível manchil da critica!...”, p. 8), como se 
atendesse a uma obrigação, ao expressar humildade e sujeição. O uso de adjetivos na p. 13 colaborou para a configuração de nação a que o autor pretende: “bemdita de Deus”, “farta”, “fresca”, “oásis”.

Mais uma vez a abordagem do narrador nos parece limitada: "Não me deterei a contar-vos do trabalho architetonico nem das alfaias de tão magnificente casa” (p. 13). Se o tom passava do formal ao menos formal (à p. 44 ele usou a forma “T'arrenégo”), também a atenção escorregava sempre do detalhe requintado para o sentimentalismo extraído da vida de Mariana Alcoforado - ou o que se pode inventar a partir do imaginário coletivo que ronda a vida dela. Ou então ia do sentimentalismo para a indiferença, como em: "E Balthazar, leal e crente, sonhava de noite com a noiva da sua alma e cavalgava de dia em longos passeios amenos com o deshonestador da sua irmã... Elle sabia lá!...” (p. 152). Outro caso semelhante é: “Houve quem se interpuzesse; a rainha sahiu e o secretario ficou limpando o suor e mastigando a indignação. Vira-se lá coisa assim!” (p. 155).

Em atenção à mesma tentativa de capturar o interesse do leitor mediante o recurso à emoção, chamamos atenção para as epígrafes. Os autores escolhidos como inspiração para a obra foram, em alguns casos, os românticos portugueses (Camilo Castelo Branco encabeça os capítulos I, II e VIII), em outros o próprio Victor Hugo (capítulo X e XII), para quem os teóricos dão tanta ênfase como inspirador do romance histórico português, além de outros artistas portugueses como Camões (XII) e Eça (IX e X).

No romance histórico escrito por Katherine Vaz, já evocado neste capítulo, não há uma epígrafe para cada capítulo, mas duas delas no início da obra. A primeira é um fragmento de uma das cartas de Heloísa a Abelardo: 
“Deus sabe que eu não hesitaria em seguir-te... até às chamas do Inferno!... Peço-te, estás em dívida para comigo, escuta as minhas súplicas. Serei breve a acabar esta longa carta: adeus, meu único amor”; e a segunda merece atenção especial por ter sido formulada por outra mulher, Emily Dickinson (1830-1886):

"O modo como leio uma carta é... assim...

Primeiro... fecho a porta....

E, a seguir... afasto-a com os dedos...

Para assegurar o seu transporte..."

A tradução das Cartas portuguesas feita por Nuno de Figueiredo ${ }^{186}$ traz por várias vezes a palavra "transporte” (no texto de 1974, as palavras do francês “mouvements” e “transports” são convertidas ora em “transporte” ora em “arrebatamento”), também utilizada na tradução da poesia norte-americana. O arrebatamento, como vocábulo e como idéia, está presente nas duas obras literárias e seria um sentimento ou um estado de alma apropriados a um amante tanto quanto a um leitor apaixonado que procura o isolamento, a fim de garantir a perfeita fruição da leitura.

Já na tradução portuguesa realizada por Eugénio de Andrade em $1969^{187}$, ficamos duas vezes pelo “arrebatamento” e uma por conta de “ardor”, observados os mesmos fragmentos. A comparação de ambos os textos das Cartas à escolha da epígrafe por parte de Katherine Vaz sugere um projeto a ser concluído, o qual comporta retraimento e gozo. Exatamente o que procurara Mariana Alcoforado, conforme nos revela a leitura da quinta carta e o que fala o eu lírico do poema de Dickinson. O obstáculo a este projeto, no caso de Mariana, era a indiferença de Chamilly, que em nada se parecia com o fervilhar dela. Daí resulta que a opção da escritora de Mariana pela segunda epígrafe

\footnotetext{
${ }^{186}$ Mariana ALCOFORADO, Cartas portuguesas, 1993, p. 15, p. 43 e p. 59.

${ }^{187}$ Mariana ALCOFORADO, Cartas portuguesas, 1974, p. 17, p. 29 e p. 35.
} 
combina muito bem com o espírito da protagonista de Cartas portuguesas. E recorrer a epígrafes, sejam elas de autores românticos (opção de Ruy Chianca) ou de poetas de outra língua e outra nacionalidade - mas do mesmo gênero -, parece-nos um acerto nestes casos.

Ruy Chianca aponta um romantismo que ele mesmo parece rejeitar: “A sóror Marianna que ora vereis, ressumbrando lágrimas de doloroso amor, nada tem daquellas definhadas e sonhadoras creaturas que povoavam as mentes românticas de nossos mais próximos avós” (p. 8). A observação, posta num quadro mais amplo, encontra eco nas afirmações de Castelo Branco Chaves, no livro O romance histórico no romantismo português ${ }^{188}$. O autor da obra teórica pontua o retardamento do gênero em Portugal, relativamente às principais literaturas européias. Se Ruy Chianca procedia à maneira dos primeiros escritores europeus que se aventuraram na escrita de romances históricos, não tinha naquelas tentativas o distanciamento temporal necessário para fugir aos esquemas românticos. Ao longo do desenvolvimento do enredo vamos assistir ao desfile de muitas situações tipicamente românticas. Não conseguimos descobrir se Ruy Chianca teria emigrado. A informação teria alguma serventia, no cruzamento com outra ponderação de Castelo Branco Chaves. E por que a preocupação com a emigração? Castelo Branco sugere que os portugueses que emigravam estavam mais sintonizados às tendências e poderiam, quem sabe, conceber um romance com contornos mais arrojados.

É possível cotejarmos os elementos distribuídos no Quadro 1 e no Quadro 2:

${ }^{188}$ Castelo Branco CHAVES, O romance histórico no romantismo português, 1979. 


\begin{tabular}{|c|c|}
\hline Em Desventurado amor, de Ruy Chianca & Em Mariana, de Katherine Vaz \\
\hline Corada & $\begin{array}{l}\text { De olhos “da cor de folhas acabadas } \\
\text { de cair de um ramo" (p. 9) }\end{array}$ \\
\hline Robusta & $\begin{array}{l}\text { De cabelo comprido, escuro e } \\
\text { encaracolado }\end{array}$ \\
\hline Desenvolta & De testa alta \\
\hline Alegre & $\begin{array}{l}\text { De lábios firmes de um vermelho- } \\
\text { gerânio }\end{array}$ \\
\hline Que amou e sofreu & $\begin{array}{l}\text { De pele de um “castanho viçoso” (p. } \\
\text { 9) }\end{array}$ \\
\hline Que acreditou e foi enganada & De maçãs do rosto largas \\
\hline $\begin{array}{l}\text { De “ondados cabellos” (p. 23), } \\
\text { “encaracoladas madeixas” (p. 23), que } \\
\text { apontam para uma convenção literária. }\end{array}$ & $\begin{array}{l}\text { Identificada com figuras femininas } \\
\text { tais como Inês de Castro (p. 16), Joana } \\
\text { D'Arc (p. 18), Santa Bárbara (p. 32), } \\
\text { Santa Clara (p. 87) e Edite (p. 104) }\end{array}$ \\
\hline Formosa & De “interessante ar triste” (p. 53) \\
\hline Activa & De “alma sensível e forte” (p. 60) \\
\hline \multicolumn{2}{|l|}{ Intelligente } \\
\hline Que tem donaire & \\
\hline
\end{tabular}

Quadro 1- Características das protagonistas 


\begin{tabular}{|c|c|}
\hline Em Desventurado amor, de Ruy Chianca & Em Mariana, de Katherine Vaz \\
\hline Mariana dos Serafins & Beatriz Maria de Rezende \\
\hline \multicolumn{2}{|c|}{ Michella dos Anjos } \\
\hline \multicolumn{2}{|c|}{ Ignez (Ignez de São José, de acordo com a versão de K.V.) } \\
\hline Constança Evangelista & Maria de Santiago \\
\hline \multicolumn{2}{|c|}{ D. Francisca Freire } \\
\hline D. Brites de Rezende & Brites dos Serafins \\
\hline \multicolumn{2}{|c|}{ D. Brites Francisca de Noronha } \\
\hline & Irmã Dolores \\
\hline & Irmã Angélica de Noronha \\
\hline & Irmã Juliana de Matos \\
\hline & Irmã Maria de Castro \\
\hline & Irmã Maria de São Francisco \\
\hline & Irmã Maria de Mendonça \\
\hline & Irmã Genebra Nogueira \\
\hline & Irmã Leonor Henriques \\
\hline & $\begin{array}{l}\text { Irmã Marina Madalena de Castro } \\
\text { Pereira }\end{array}$ \\
\hline & Irmã Isabel Pereira \\
\hline & Irmã Joana de Lacerda \\
\hline
\end{tabular}

Quadro 2- Personagens do núcleo do convento 
Se Ruy Chianca dissera que as freiras estavam lá ou por penitência (pois haviam pecado) ou porque tinham sido encarceradas, mas em ambos os casos mantinham o espírito livre, Katherine Vaz não entrou por estas considerações mais maniqueístas e nem afirmou, como ele faz, que todas eram devotadas. A escritora norte-americana de ascendência portuguesa colocou às páginas 55 e 56 os nomes reproduzidos na lista acima e foi apresentando uma a uma, na medida da necessidade que o enredo impunha.

Ruy Chianca tinha chamado algumas daquelas freiras de "as mais mimosas das noivas de Jesus” (p. 14) ou de "professas gentis” (p. 15) e outras delas de “rosas fanadas, murchas”, mantidas por uma "haste frágil” (p. 15), o que nos deixa com a impressão de que ele optara por idealizar e por polarizar. $\mathrm{Na}$ aposta que ele fizera, de relatar a história pessoal das freiras, dava vazão ao projeto de apresentar e valorizar as genealogias portuguesas. Com relação à família Alcoforado, é importante salientar que, como à p. 20, ele muitas vezes mencionara e descrevera o "heráldico brazão”.

Katherine Vaz, munida de pesquisa acerca do contexto de Mariana Alcoforado, associou a freira a ícones femininos, como Inês de Castro (p. 16) e Joana D’Arc (p. 18), presentes no Quadro 1. Na trama do livro, o nome da personagem histórica portuguesa veio à baila por conta de uma aspiração da protagonista, que na juventude tinha idealizado o amor como a melhor arma contra a apatia (ela dizia que se precavia contra o risco de um dia ser alma penada). Já o nome da francesa ilustre surgiu num diálogo em família; Mariana era alvo de comentários jocosos, como se tivesse vocação para o sacrifício e qualidade de visionária. 
A Mariana Alcoforado que reviveu por obra de Katherine Vaz é mais credível, porque menos idealizada do que as freiras de Ruy Chianca. São provas disso: 1) o fato de, à p. 23, ela desfalecer enquanto sonha; 2) a menção à leitura laica, à p. 26 (de Cervantes); 3) o “Quero casar” dito ao pai (p. 28); 4) o conhecimento sobre as intenções do pai em preservar intacta a herança do morgadio (p. 51); 5) uma observação expressa em forma de pergunta, que ela assim se faz em silêncio: "Freiras? - repetiu Marina. Será que se parecia com uma freira?” (p. 95); 6) é apaixonada que ela julga estar, enfim, conhecendo a religião. As 279 páginas do livro certamente permitem o levantamento de mais exemplos concernentes ao tema, mas voltemos por ora a Ruy Chianca.

O uso do discurso direto representa oportunidade de o escritor imaginar o que é que as freiras imaginavam, incorrendo de certa forma num anacronismo, pois a noção de família e de afeto (importantes para a leitura do excerto que segue) no século XVII era distinta da época em que ele redigiu o romance Desventurado amor:

"Meu Senhor! Que razão há para que me apartem do mundo? Não será n'elle, por certo, o peccado de tal maneira perdedor, que minha irmã não seja respeitada no thalamo do esposo e minha mãe, uma santa, no lar da minha infância! Para que tão duramente penitenciar-me, se não vejo dentro da minha alma crimes de que me accuse?! Se Deus creou o céu e a terra, porque não gosarei o sol de Deus, nem serei livre como as andorinhas que se aninhavam sobre as janellas da minha alcova, - egual a ellas na alegria e na liberdade?! Senhor! Porque foi que apens despida das fachas bordadas por minha mãe quando esperava que eu nascesse, me envergaram logo essa aspérrima mortalha que fere as minhas carnes mimosas e tantas vezes beijadas pelos lábios de meus pães?!” (p. 22).

Os amores freiráticos são muitas vezes referidos no desenrolar da história, mas de um modo nada velado, ao contrário: Ruy Chianca os introduziu nos diálogos, como se em família de fidalgos fosse usual falar desse tema. A 
inserção vai contra a noção de discrição dos homens barrocos. Mesmo que o autor tenha empregado a expressão “escândalos conventuais” (p. 55), vulgarizava de alguma maneira a discussão dos envolvimentos eróticos entre nobres e freiras. Também Katherine Vaz abordou a questão - difícil seria evitála: são os parentes que comentam o constrangimento causado por Mariana (p. 146), é a irmã casada que procura reconfortá-la (p. 161), é a Madre Superiora que abomina a distribuição das Lettres portugaises (p. 208).

Na literatura, este tipo de tratamento não é exceção, podia ter um caráter ao mesmo tempo de reprimenda e de provocação da curiosidade do leitor. Examinemos um poema de Gregório de Matos (1623/1633-1696), para brevemente ilustrar o tratamento que se dava ao assunto ${ }^{189}$ :

"Senhora minha: se de tais clausuras

Tantos doces mandais a uma formiga, Que esperais vós agora, que vos diga, Se não forem muchisimas doçuras.

Eu esperei de amor outras venturas:

Mas ei-lo vai, tudo o que é de amor, obriga, Ou já seja favor, ou uma figa,

De vossa mão são tudo ambrósias puras.

O vosso doce a todos diz, comei-me,

189 Ana MIRANDA, Que seja em segredo, 1998, p. 69. A autora explicou que as freiras de alguns conventos portugueses levavam vida cheia de caprichos e de regalias, assim como em Nova Espanha, onde algumas delas tinham celas luxuosas, inclusive com os variados presentes que ganhavam dos amantes. Além de se embelezarem, as freiras portuguesas liam a qualquer hora do dia e faziam doces. Deste derradeiro pormenor surge para nós uma outra leitura. Lembremos que o autor do poema, Gregório de Matos, foi conhecido pela alcunha de "Boca do Inferno"; criticava comerciantes, criava polêmicas com políticos do estado da Bahia e fazia inimigos, enfim, com certa facilidade. Também produzia poesia erótica. No caso que ora examinamos, diz-se "glutão" e "formiga" como quem insinua o apetite sexual. Afirma que falará de "doçuras" à preferida, como quem fará gracejos picantes. E finalmente promete continuar a querer os favores sexuais, isto é, permissão para ultrapassar as grades e estar na intimidade de uma reclusa, uma vez que apetite não lhe falta e ela está sempre a oferecer-se, a oferecer seu “doce”. Haveria circunstâncias, dentro do espaço doméstico e nobre, para conversarem a propósito de encontros da natureza deste, sobretudo se ponderarmos que a família Alcoforado tinha no convento mais de uma filha? Não se afigura como hipótese fácil de defender. O romance histórico de Ruy Chianca, por isso mesmo, perde um pouco em coerência. 
De cheiroso, perfeito, e asseado,

E eu por gosto lhe dar, comi, e fartei-me.

Em este se acabando, irá recado,

E se vos parecer glutão, sofrei-me,

Enquanto vos não peço outro bocado".

Por outro lado, desafia-nos em nossa apresentação que investe contra a coerência do autor deste romance histórico um caso interessante de verossimilhança no enredo de Desventurado amor: Mariana estaria a admirar um quadro do perdão de Madalena, representante de “encantos profanos, harmoniosamente ligados n'um todo perfeito, religioso e bello!” (p. 82). Preferia a estabilidade das mártires a esta figura que via. A cena é plausível, dado o perfil que o autor veio traçando para ela. Ela acreditava no sacrifício das mártires, mas se dava a chance de conversar com Madalena e passava a considerar aceitável o afastamento da rígida prática religiosa. Além de encaixar-se no perfil dela, temos que aceitar o fato de que no período em que a freira portuguesa teria vivido reinava a convicção de que pinturas podiam ser lidas e de que as vidas dos santos deviam ser estudadas.

Pensemos um pouco mais nas personagens do núcleo dos Alcoforado: o fidalgo Francisco Alcoforado é apresentado como alguém de muita “descortezia” (p. 59), contrariando a noção de decoro e de agudeza, na medida também em que sustenta um diálogo tão cru e fácil de decodificar com a personagem de Chamilly. Parece que o autor tentou adaptar o perfil do homem seiscentista à faceta do português - como ele a concebe -, pois Balthazar em seguida à brutalidade do pai, diz: "Portuguez de lei, homem de coração” (p. 61).

A figura de Thomé (uma vez referido incorretamente no texto como “Thomás”, p. 40) lembra em muito Quasímodo, a personagem de Notre-Dame 
de Paris (1831), romance de Victor Hugo. Era ao mesmo tempo doce e monstruoso, tinha uma deformação física, tocava os sinos da igreja e se arriscava pela heroína. O artifício do autor português consistia em colocar o acólito na condição de alcoviteiro. Katherine Vaz, por seu turno, seguiu a linha das Cartas portuguesas e fez de Baltazar, irmão de Mariana, o facilitador dos encontros entre os amantes.

Passando a outro núcleo de personagens, observemos que a figura da freira Brites Francisca de Noronha coincide com a que Almada Negreiros pintara fazia pouco, embora no ataque empreendido por ele o alvo fosse Mariana Alcoforado $^{190}$. Enquanto ela a chamava de "histérica” (p. 11), Ruy Chianca chamava Brites de "phrenetica” (p. 32), algo um pouco mais suave, embora agressivo também. O sucesso que Ruy Chianca teve em função das peças teatrais, do início até a metade do século $\mathrm{XX}$, ajuda a calcular o peso que a predileção pela figura de Mariana Alcoforado representava.

Ruy Chianca recorrera a alguns clichês, ao escrever que as mulheres têm um corpo que fala, ao passo que os homens são de "bem estudada modéstia" (p. 32), à maneira de Chamilly. Mariana, por exemplo, abstraía; Chamilly, por seu turno, portava-se como um “leão contente” (p. 34). Abuso dos clichês está igualmente na passagem em que o irmão de Mariana dizia que ela era "virtuosa” (p. 62) e não tinha desejos. Justamente numa época de conflito espiritual e carnal como o XVII? Em Nova Espanha, precisamente à mesma época, se quisermos parâmetro para comparação, havia mulheres temidas pelos homens, como é o caso de Sor Juana Inés de la Cruz. Não era preciso que Ruy Chianca forjasse

\footnotetext{
190 Almada Negreiros compôs O Manifesto Anti-Dantas e Por Extenso em 1915: "O Dantas fez uma Sóror Marianna que tanto o [sic] podia ser como a Sóror Ignez ou a Ignez de Castro, ou a Leonor Telles, ou o Mestre D’Aviz, ou a Dona Constança, ou a Nau Cath'rineta, ou a Maria Rapaz! E o Dantas teve cláque! E o Dantas teve palmas! E o Dantas agradeceu! (...) A Marianna que é histerica começa de chorar desatinadamente nos braços da sua confidente e excellente pau de cabelleira Soror Ignez” (pp. 8-11).
} 
uma heroína tão pura, a não ser que pensemos estritamente no gosto neoromântico do escritor.

Percebemos anacronismo na concepção da personagem Margarida, tia de Mariana, pois o narrador sugere a idéia de que ela sentia saudades das sobrinhas enclausuradas (e só o podia sentir), o que não aconteceria obrigatoriamente, se pensarmos nos usos daquela época.

Aquilo que Balthazar reconhecia como “ironia picante do amigo” (p. 63) nos parece estar abaixo do estilo da obra atribuída a Mariana Alcoforado, mesmo que ela já tenha sido acusada com o argumento de que "o livro não tem

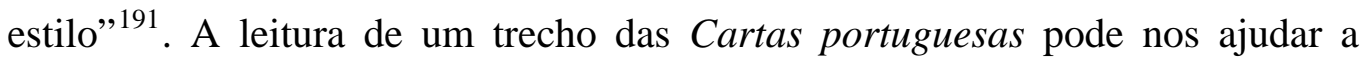
formar um juízo a este respeito, embora o julgamento de questões estilísticas seja subjetivo:

"Estou viva, infiel que sou! E faço tanto para conservar a minha vida como para perdê-la! Ah!, morro de vergonha! O meu desespero estará então apenas nas minhas cartas? Se te amasse tanto como mil vezes te tenho dito, não teria já morrido há muito tempo?

Enganei-te!, e és tu que te deves queixar de mim. Ai de mim!, e porque o não fazes? Vi-te partir, não posso ter esperança de te ver voltar, e, no entanto, respiro! Enganei-te, afinal, e peço o teu perdão" (p. 47)

No princípio do excerto, encontramos uma formulação bastante eloquente, “Estou viva, infiel que sou!”. Ela poderia ser ouvida numa recriação teatral do texto original seiscentista, por hipótese, para que o espectador, passada a encenação, recordasse do fragmento de forma isolada, independente do que estaria antes e depois. A pontuação, além disso, permite modulações na entonação dada a esta leitura sonhada. A autora utilizou uma hipérbole ("mil vezes te tenho dito”) e fez uma pergunta retórica, de forma a incentivar o

\footnotetext{
${ }^{191}$ Mariana ALCOFORADO, Cartas portuguesas, 1974, p. 119.
} 
raciocínio do interlocutor, para depois continuar o discurso com uma interjeição seguida de outra pergunta retórica.

De um outro excerto, citado parcialmente no capítulo IV, o cuidado na escolha lexical é o que interessa ${ }^{192}$ : temos o verbo “encantar”, o adjetivo “fatal”, a aproximação do adjetivo "infeliz” ao substantivo "paixão”, a descrição do impacto visual - e a visão é um sentido tão caro à literatura, desde há muito, basta lembrarmos Petrarca e Camões a falarem dos olhos das amadas -, feita por intermédio das expressões "tua destreza” e "boa graça” e, igualmente, a força de um “apoderava-se” rematada pelo advérbio “secretamente”, a dar o tom da imaginação solitária de Mariana face a sedução assistida de Chamilly.

O mero uso de recursos ensinados pela Retórica, tais como metáfora, metonímia, aliteração, assonância, elipse, hipérbole etc não implica em qualidade do texto, pois o ornamento pode ter sido emprestado a uma mensagem completamente vazia de sentido.

Por outro lado, e para encerrar neste ponto a análise textual do romance de Ruy Chianca, digamos que o autor conservou, do texto atribuído a Mariana Alcoforado, a ambiguidade dos sentimentos, como se pode notar na expressão “deliciosa tortura” (p. 125) por ele forjada; ela é análoga às construções originais “está em França no meio dos prazeres e nem por um momento pensa nas tuas dores”, “tão cruéis as lembranças de momentos tão agradáveis” $^{193}$ (grifos nossos) e “encontro-me dilacerada por mil movimentos contrários”194.

\footnotetext{
${ }^{192}$ Mariana ALCOFORADO, Cartas portuguesas, 1974: “(...) naquele dia fatal em que comecei a sentir os primeiros efeitos da minha infeliz paixão (...) se eu te visse melhor e se admirasse a tua destreza e a boa graça quando montavas o teu cavalo. Apoderava-se de mim um certo temor quando o fazias passar num lugar difícil; enfim, interessava-me secretamente por todos os teus actos ...” (p. 67).

${ }^{193}$ Mariana ALCOFORADO, Cartas portuguesas, 1974, p. 15.

${ }^{194}$ Ibid., p. 45.
} 
"Aquest'outra hirta e severa? Não deu em sua alma acolhimento ao amor dos homens. É quem ensina o latim das orações. Rosas fanadas, murchas, por onde só corre seiva morta; se o vento das paixões mundanas soprasse um instante no ambiente das suas cellas, ve-las-hieis em pó, desfeitas, cahindo sem vida como a haste frágil que as mantem” (p. 15).

Finalizando a apreciação desta obra que repercute criativamente as Cartas portuguesas, notemos que a protagonista Mariana, que não se permitia nutrir ódio por um semelhante, cedeu ao vento das paixões, exatamente o que fazia dela figura privilegiada para ocupar o lugar de protagonista. Com este raciocínio ou com este valor o autor concebeu o livro. Sublinhou esse traço e, então, não colocou o leitor tão perto dos acontecimentos históricos.

Porque era “filha dilecta”, “graciosa” (p. 68), Mariana se deixara inundar de amor e, conforme descobrimos ao ler o desfecho da história de 1916, morreu bonita e valorosa. O amor de alguém do outro sexo não a corrompeu, não instilou na alma dela qualquer veneno (sensivelmente o ódio pelo amante). Os fatos históricos passados em Portugal naquele período também não assumiram, aos olhos dela, nenhuma conotação especialmente caracterizada pelo narrador. Ruy Chianca realçou a vivência íntima da aventura amorosa de Mariana Alcoforado e, ao executar essa tarefa, deu preferência a uma heroína de tipo ideal, que se entrega, sofre, mas não sucumbe.

Também o papel que ele reservou a Chamilly é bastante convencional, como se nota no seguinte fragmento:

"Ora, nós, pessoas de claro entendimento, bem acepilhado de quantas máximas de indifferença a philosophia moderna rebatinha ao egoísmo em nome da civilisação, oh! para nós, Noel de Chamilly é uma creatura absolutamente honesta, espirituosa, fidalga que - está-m'o dizendo aqui ao ouvido um mercador meu amigo que empresta a 6 por cento ao mez - devia 
contar deliciosamente anecdotas picantes quando chegou a marechal de França e que já não podemos convidar para as nossas reuniões familiares para lhe gosarmos o riso malicioso e o olhar brejeiro, porque infelizmente morreu há dois séculos!” (p. 166).

Quase como fizera muito tempo antes D. Francisco Manuel de Melo, ao aconselhar discretamente os grandes em Carta de guia de $\operatorname{casados}^{195}$, esse receptor da herança alcoforadista de fins do século XIX pensou em reproduzir a figura de um homem que merecia lugar num livro pela capacidade de liderar, de conduzir - este seria o papel dele na vida de Mariana. Se D. Francisco estivera desejoso de incentivar os homens a governarem a casa e a exigirem da mulher que se lhes garantisse a honra, consoante o que constatamos no capítulo anterior, Ruy Chianca estava inclinado para talhar um homem que cumprisse aquilo que era esperado de um homem à época, ou seja, que aproveitasse a vida em termos práticos. O sentimentalismo cabia à mulher e a vivência profunda dos acontecimentos da nação e do mundo sequer aparecia no horizonte ou, quando muito, nele permanecia, distante das reflexões e das atitudes das personagens.

\section{Uma forma nova de dizer: Novas cartas portuguesas}

Perante a dificuldade em catalogar a obra ou como romance ou como poesia ou como coletânea de cartas, subscrevemos Maria de Lurdes Pintassilgo que, no Pré-prefácio para a edição de 1980 sob responsabilidade da Moraes Editores, assim se pronunciou:

"São (...) ainda mais: uma nova forma de dizer a pessoa humana e o seu modo de estar no mundo, um ensaio que

${ }^{195}$ D. Francisco Manuel de MELO, Carta de guia de casados, 2003. 
se quer filosófico, mas que toca as raízes do ser, um contributo inédito para a antropologia social, no que (à maneira de um Garcia Marquez ou de um Óscar Lewis) recolhe de vida, de sensações, de comportamento singulares universalizados” (p. 8).

À apresentação das co-autoras, no entanto, não nos furtamos. Em função da leitura que faremos, elas já devem ser apresentadas como três conhecidas literatas portuguesas que, num exercício (de investigação, de reorganização, de escrita, de comparação e de rompimento com a solidão do trabalho intelectual, finalmente) coligiram as respectivas produções textuais, semana após semana durante nove meses. Tomando cuidado para resguardarem a autoria de cada exemplar avulso, faziam uma leitura em voz alta, como quem procura dar à atividade uma liturgia. São elas Maria Isabel Barreno, Maria Teresa Horta e Maria Velho da Costa. As três autoras de Novas cartas portuguesas proclamam um concerto de três, com um instrumento de cordas, quem sabe um instrumento de três cordas.

Vê-las e projetá-las como mulheres imbuídas do mesmo espírito apaixonado de Mariana Alcoforado, figura feminina do século XVII português, parece-nos bastante correto $^{196}$. Pelo espírito apaixonado e por deliberarem, tiveram êxito em transformar a palavra creditada a uma só mulher em aposta

\footnotetext{
${ }^{196}$ Maria Teresa Horta, entrevistada para esta tese em Lisboa, no dia 04 de julho de 2009, surpreendeunos com o gosto que ainda demonstra quando fala do livro Novas cartas portuguesas, detalhando a pesquisa, as notícias da recepção, as traduções e o apoio dado por grupos feministas. Evidentemente que o projeto que reforça o sentido do livro se prende a outros projetos dessa jornalista e ficcionista, mas mesmo assim, é recontado com interesse particular e com firmeza. Alguns episódios relatados contribuíram bastante para o desenvolvimento desta pesquisa. Fixamos, por exemplo, a violência verbal de um dos homens que espancou Maria Teresa Horta (e que teria dito mais ou menos "Isso é para você aprender a não escrever como escreve”). Antes que pensássemos na ameça que a frase encerrava, a própria escritora fez questão de enfatizar aquilo que considera o absurdo do pedido: como ela poderia desaprender a escrever, se crê no poder da palavra e se crê na existência de uma escrita feminina? E como se sente a mulher que, depois de trabalhar muitas vezes na recolha de material a respeito das circunstâncias de vida das prostitutas em Portugal, é interrogada pelos mesmos policiais que interrogam e intimidam as próprias prostitutas? Compreender a realidade da mulher será forçosamente viver a realidade da mulher hositilizada? Por último, lembramos, a instâncias da própria entrevistada, que a única pessoa que enfrentou um superior hierárquico para manter a promessa de publicar Novas cartas portuguesas, à altura do escândalo que a censura inflamou, foi uma mulher. Natália Correia, então diretora-literária dos Estúdios Cor, teve essa postura.
} 
coletiva; isto faz delas, desde a década de 70 do século passado, agentes culturais livres e, ao mesmo tempo, articuladas e criativas. A experiência empreendida resultou, no entanto, num processo judicial e em restrições só retiradas com a chegada do 25 de abril de 1974.

O livro dessas três autoras é uma rica mescla de poemas (cerca de 50, na maior parte dos casos, curtos) e de textos em prosa (cerca de 70, com tamanho maior que o dos poemas, mas entre si bem variável, às vezes assumindo a forma concreta de um verbete de dicionário, por exemplo), todos ficcionais ${ }^{197}$. Todos datados. Grande parte deles com o vocábulo “carta” no título, referência direta ao gênero textual a que se liga o original atribuído a Mariana Alcoforado. Mas não vão além da carta de número três em cada uma das oito séries de cartas - nem todas completas nem todas lineares -, ficando “Primeira Carta I”, “Segunda Carta I”, “Terceira Carta I”, “Primeira Carta II”, “Segunda Carta II”, “Terceira Carta II” e assim sucessivamente. Em várias cartas existe também assinatura. Assinam as cartas fictícias Ana, António(s), António M., António Mourinhas, Joana, José Maria, Mãe, Maria, Maria Ana, Maria Adélia, Mariana, Mónica e Noel, em cujos nomes podemos reconhecer fragmentos do nome Mariana e novos nomes, até mais vulgares em Portugal, para simbolizarem histórias de repressão também elas repetidas nesse país e em outros. Diversos elementos do universo da freira de Beja, como também do universo feminino em geral, compareceram nos títulos: “Alba”, "Brinco de

\footnotetext{
${ }^{197}$ Pontuamos que as páginas 88, 89, 90, 91, 92, 93, 94 e 95 contêm textos curtos sobre personagens lendárias e personagens históricas. São elas Elisabeth de Hoven, Maria de la Ralde, Louise Maillat, Marie Mariagrane, Gabrielle de Strées, Cecília, Marguerite de Brinvilliers e Madame Deshoulières. A estranheza do material, reunião de dados sobre mulheres consideradas adúlteras, bruxas, mulheres que procederam a envenenamentos em série, amantes de reis etc, deve auxiliar os leitores a perceberem que Novas cartas portuguesas é fruto de pesquisa, de investimento na dissecação da condição feminina. Para além disto está o fato de que partilhar com o leitor esses dados, invertendo a lógica segundo a qual tais mulheres eram pouco mais que criminosas, fez com que mudassem de estatuto; se o leitor acredita no poder dessas mulheres de atitudes pouco convencionais, pode vê-las melhor.
} 
Freira”, “Sela e Cela”, “O Cárcere”, “Texto sobre a solidão”, “A Filha” e “Ditos de mulher e homem”, entre outros.

A intertextualidade que habita as quase 400 páginas da primeira edição brasileira de Novas cartas portuguesas leva o leitor, nos intercâmbios mais explícitos, até: 1) à própria Maria Velho da Costa, como a autora de Maina Mendes (p. 40); 2) ao poeta português Alexandre O’Neal (p. 55); 3) ao cineasta português Paulo Rocha, por causa do filme "Verdes anos”, de 1963, em que um jovem rapaz assassinava a namorada (p. 55); 4) a Agustina Bessa-Luís, por causa da obra A mãe de um rio (à p. 69); 5) à obra Tristão e Isolda (p.72 e p. 110); 6) à obra Abelardo e Heloísa, de recepção muito boa em Portugal (p. 110); 7) à Bíblia (p. 128 e p. 137); 8) à obra de Lewis Carrol, Alice no país das maravilhas (p.128); 9) a Albertine Sarrazin, a escritora francesa falecida em 1967 (p. 201); 10) a Shakespeare (p. 239); 11) a Reynaldo Arenas, o escritor cubano falecido no ano de 1990 (p. 254); 12) a Ti-Grace Atkinson, a feminista norte-americana (p. 285); 13) a Paul Chanson (p. 292); 14) a Gil Vicente, como o autor do Auto de Mofina Mendes (p. 311); 15) a António Maria Lisboa e a Florbela Espanca (ambos à p. 336). Maria Teresa Horta, co-autora, pessoalmente chamou nossa atenção para o fato de que, se fosse feito hoje, o livro teria sem dúvida mais fontes, dado o ganho da experiência de vida de cada uma das três envolvidas e a profusão de artigos, os mais variados, que nascem para incrementar a discussão da condição da mulher.

Há algumas epígrafes, como a da p. 119, extraída de Eugénio de Andrade; a da p. 122, de Ezra Pound; a da p. 193, de William Blake; a do poeta Leo Ferré, à mesma p. 193; a de Elizabeth Barrett Browning, autora de Sonnets from the Portuguese, à p. 257. 
Foram transcritos quase no fim do livro alguns parágrafos do Código Penal Português, Artigo 372. Há, em suma, muitos corredores, muitas portas e muitas janelas nesta construção a três e daí resulta que a obra possa ser lida em razão de uma inquietação do leitor quanto à ambiguidade do amor, em razão de uma identificação do leitor com o tema da morte da opressão, em razão de uma busca do leitor pelo (re)nascimento da escrita feminina.

Falam a um público largo, precisam então de um leque muito grande de situações inventadas ou lembradas. A esse propósito, reproduzimos trecho da p. 52, que remata duas histórias de mitos ou lendas que pouco interessava às autoras contextualizar, mas que pontuavam a importância da passagem das mulheres a condições diversas do aprisionamento:

“(...) o meu exercício é o da vingança; que quem está ferido não se recolha, antes despeje o seu sangue no mundo. Porque o objecto da paixão é mesmo pretexto, pretexto para nele ou através dele, definirmos, e em que sentido, o nosso diálogo com o resto."

Principalmente o aprisionamento da identidade feminina (estado provável ou possível, no contexto de um claustro como o que confinou a freira de Beja por quase toda a vida) e o indispensável fluxo de mudança a partir desse mesmo estado parecem estar subentendidos nas opções das escritoras: elas evocaram o vidro prestes a romper-se (material ou não, fator de isolamento ou não), a pedra e a água para mostrarem obstáculos que já estão cristalizados, naturezas encerradas e o avesso, isto é, fluidez. Podemos observar esse movimento da clausura para o caminho pessoal expresso de muitas formas nas páginas 32, 36, 37, 43, 44, 45, 55, 59, 61, 67, 74, 128, 148, 164, 194, 291, 309, 331, 332, 337 e 343. 
Como catalisadores neste processo de alteração das engrenagens que detêm as mulheres, as autoras situaram a escrita, o amor e a paixão. São ambivalentes os três, mas no raciocínio delas eles funcionaram como combustíveis, como alimentos, como bandeiras. Elas interpretaram o exemplo de Mariana sob o ângulo da entrega que esvazia a mulher, mas também sob o ângulo do instrumento, isto é, enxergaram Mariana como personagem que soube sair da solidão e do silêncio por meio da paixão por descobrir-se, por meio do desejo de ver-se no outro, por meio do desejo de ver-se num texto, dita pelas palavras que antes apenas aceitava. E assim postularam: “Que outra maneira tenho de examinar as coisas, os outros: com toda a minha paixão?... Assim te procuro, te uso, te escrevo” (p. 48). É igualmente muito claro o fragmento da p. 50: “Que seria de nós sem tanto amor -, pelo puro desprazer que isso nos daria.” Se quisermos comparar estas criações com um fragmento do original, teremos:

"Ah! Fui eu a culpada de todas as minhas desgraças: primeiro habituei-o a uma grande paixão, onde havia demasiada simplicidade - e é preciso artifícios para se fazer amar; é preciso procurar, com uma certa habilidade, os meios de inflamar, pois o amor, só por si, não gera o amor»"198.

Quando avisam que a cada insubordinação cabe uma clausura, parecem estar de acordo com Katherine Vaz, que concebeu para Mariana uma infância cheia de sonhos e de rompantes de vivacidade e saudável desobediência, significativamente seguida do encaminhamento para o convento. Teria sido, além de prevenção, punição?

O experimentalismo do texto sem dúvida permite muitos mais comentários. Fiquemos, entretanto, com cinco pontos extras: 1) a evocação em muitas páginas de um espírito pueril e obediente que, como vimos, Katherine

\footnotetext{
${ }^{198}$ Mariana ALCOFORADO, Cartas portuguesas, 1974, p. 95.
} 
Vaz também procurou em Mariana, a personagem histórica, embora de maneira menos contestadora; 2) a maternidade conturbada, multifacetada, que o filme argentino Yo, la peor de todas, também apontou no imaginário de Sor Juana; 3) a problematização da violência masculina como reação à expressão da sensualidade feminina; 4) o acostumar-se da mulher reprimida ao corpo e aos desejos; 5) a agressividade, que já estava na abordagem de Mariana ao interlocutor Chamilly.

Nessa mesma ordem, seguem-se os apontamentos para a reflexão evocada no esquema: o texto da p. 74 chama-se “Cantiga de Mariana Alcoforado a Sua Mãe”, o da p. 85, “Cantiga de Mariana Alcoforado à maneira de lamento”, nas páginas 61 e 103, vemos uma narradora que se diz "moldada”, como quem aceitou prendas (fitas, roupinhas) e mimos e conselhos até se tornar objeto, comodamente pousado na casa da família.

À p. 148, o texto da mãe. Num dia de chuva, uma mãe refletia sobre a filha ausente e tinha as mãos ocupadas em segurar outro filho pelas ruas. Relembrava uma carta/bilhete doce, da filha Maria. Relembrava versão mais crítica, fruto de uma filha Mariana. Estava possessa e voltava-se contra a criança que brincava na chuva. Cabeça contra o vidro - marca da cidade e suas separações -, feriu a criança. Tornou a si desorientada, aflita. Toda mulher tem de assumir as dores, as ânsias, os imponderáveis? É a pergunta que o texto sugeriu.

À p. 161, o texto do pai começava com um seco “Era perversa”. Um narrador enumerava os pensamentos de um pai sobre uma filha Mariana, jovem, atraente e livre. A expressão “Era perversa” deixaria de aparecer apenas quando ele brutalmente a atacasse dentro do quarto dela, cometendo o estupro e em 
seguida pedindo que ela saísse de casa, porque a convivência estava impossível. Também a brutalidade da mãe, que chama a filha de "Grande cabra” não vem precedida do “Era perversa”.

À p. 64, o texto “A Paz” nos torna observadores privilegiados do comprazer-se de Mariana. Nada mais interessa a ela, conforme lemos, a não ser o corpo e os limites que ele rompe, as misturas que ele produz, a lassidão que naquela circunstância chamou paz. O hábito está mencionado somente uma vez (na segunda linha), nenhum som nem cor nem aroma ambiente tiram Mariana daquela abstração e daquele contato, a referência às cartas e aos motivos delas surge tão somente para mostrar quão dispensáveis elas são naquele momento. Provavelmente a inspiração para a redação do texto nasceu de excertos como o da p. 43 das Cartas portuguesas: "Lamento, só por amor de ti, os prazeres infinitos que perdeste: será que os não tinhas querido gozar?”.

Existem, enfim, posturas ativas e posturas passivas, pautadas pela nostalgia e pela vingança, sendo a primeira delas aquela que constrói "uma irmandade e um convento” (p. 31).

\section{Mariana em cena}

A montagem brasileira esteve em cartaz nos anos de 2004 e 2005 e coube à companhia Teatro Curupira. Foi vista no Teatro do Nó, na cidade de Santo André, região metropolitana de São Paulo, graças à propaganda feita pelo jornal da Casa de Portugal em São Paulo, publicação chamada “Mundo lusíada”.

Mariana estava só em um pequeno espaço delimitado apenas pelas cadeiras postas à disposição do público aguardado, como só estaria também no momento da enunciação das Cartas portuguesas. Durante toda a peça falou sem 
se dirigir a um qualquer interlocutor, exprimia sofrimento e tortura, contudo estava tão próxima da platéia, que acabou por envolvê-la completamente, à semelhança do envolvimento produzido no leitor solitário pela leitura dos textos em papel.

O figurino igualmente remetia à sensação de dor, pois ao invés de um hábito, Mariana vestia ataduras, pequenas faixas amareladas, anulando, assim, a noção de beleza que está no texto do século XVII. Nele, Mariana reporta-nos ao garbo de Noel e também aos atrativos físicos dela própria. Convém lembrar mais uma vez de Michel Foucault, que no volume I de História da sexualidade situara um pouco antes da época de Mariana o período correspondente a um aumento na preocupação com o corpo e, por isso, num maior aparecimento de textos sobre o corpo ou textos em que surgem referências ao corpo. Porém o diretor da peça, em colaboração com a artista plástica e também fotógrafa Huelita Rabelo, parece ter cristalizado na imaginação uma figura triste desse expoente da cultura portuguesa, que aliás parece estar adoentada também por causa da postura do corpo e do tom de voz.

O monólogo foi longo e os gestos conformavam, de fato, o movimento de Mariana na intenção de pedir, de quase tomar de Noel o que ela julgava ser dela. A atriz se projetava para a frente, estendia os braços, não sugeria equilíbrio. E a harmonia, como sabemos, estava distante do contexto português da segunda metade do século XVII. Mariana, a personagem histórica, nasceu na vigência da Restauração, provavelmente viu Beja transformar-se num local inseguro em razão das batalhas e teve de suportar o abandono do pai influente e a rotina do convento, até a convulsão provocada pelo escândalo. E 
este último item de instabilidade na vida da freira talvez tenha-se configurado o menos inoportuno, afinal.

Terminada a sessão, atriz e diretor sentaram-se com a audiência e se disponibilizaram para responder a quaisquer perguntas em torno daquela montagem. Haviam lido as cartas, evidentemente, tiveram cuidado em combinar com a criadora do figurino uma concepção que agradasse aos três leitores da obra e, em nós, deixavam também a suspeita de que é possível depreender da situação da mulher portuguesa do século XVII um profundo desamparado, em nada parecido à paixão que intimamente ela sentia.

\title{
4. O Marquês de Chamilly (Kabale und Liebe) ${ }^{199}$
}

\author{
FIN \\ Meu senhor \\ como diz a Mimi \\ prenez garde à vous \\ pois se não me escreve cartas \\ eu escrevo-lhe cartas \\ (p. 85) \\ 1 \\ À medida que a paixão \\ acabava \\ o cabelo dela ia ficando \\ por lavar \\ usou um chapéu \\ mas a partir de certa altura \\ meu amor \\ não foi suficiente um chapéu \\ 2 \\ Estou outra vez a escrever-lhe \\ para lhe dizer \\ outra vez \\ que não lhe escrevo mais \\ lembra-se dos pesados cortinados \\ de veludo cor de canela do meu boudoir? \\ eu também
}

${ }^{199}$ Adília LOPES, Obra, 2000, pp. 85-97 
Uma das coisas

que Marianna mais detesta

é a publicidade

ao código postal

detesta o meio caminho andado

lembra-lhe o paradoxo

de Aquiles e a Tartaruga

meio caminho andado

meio caminho

e mais um quarto

andados às voltas

a torcer o lenço nas mãos

meio caminho e mais um

oitavo andados

a irmã Octávia toma rapé

que desgosto

meio caminho e mais um dezasseis

avos andados

favos a aves que nojo

meio caminho e mais trinta

e dois avos andados

qualquer dia faço eu trinta anos

e assim por diante que raiva

(p. 86)

Marianna faz vinte e oito anos

Marianna em virtude

de imaginar

que abre cartas

abre

nervosamente

a caixa de bombons

que uma irmã lhe oferece

pelos anos

outra mais maliciosa

oferece a Marianna

um mealheiro

é um marco de correio

em ponto pequeno

Marianna queima-o na braseira

com dinheiro dentro

o dia em que eu nasci moura

e pereça

blasfema Marianna

o dinheiro não traz o marquês de Chamilly

o dinheiro não traz o marquês de Chamilly

sobretudo quando é pouco

pensa Marianna 
mas não se deve pensar assim

nada pior do que estar apaixonada

por um gigolo

Marianna pensa em apaixonar-se

Por um gigolo

Mariana enrosca-se como uma

mulher de Argel de Delacroix

para pensar no marquês como num gigolo

Marianna enrosca-se mais

mais

(pp. 86-87)

Marianna não desiste

abre pela terceira vez

nesse dia

a caixa do correio

lá dentro está qualquer coisa

que ela não percebe bem

o que é

e que brilha

era uma folha de hera

Marianna desata

a chorar

e espezinha a folha de hera

que depois morde

até sentir na boa o amargo

da folha

assim se passou mais um inverno

depois vem o verão

Marianna abre sempre a caixa do correio

lá dentro de uma vez

uma lagartixa fita-a

Marianna beija a lagartixa e chora

depois vai-se deitar a ouvir Bach

l'été a apaisée

depois vem a noite

a lagartixa adormece aos pés de Marianna

Marianna não consegue dormir

e canta

as outras mandam-na calar

(p.88)

Os poemas de Adília Lopes quase dispensam comentário. A leitura

deixa muito clara a forma como eles se aproximam de Mariana Alcoforado. É explícito o desejo de nos levar até Mariana despidos de qualquer emotividade, de qualquer tentativa de identificação (com a sensualidade, com os sentimentos, 
com as sensações ou com o espaço físico descrito pela religiosa das Cartas portuguesas), para que assim tomemos a opção pelo riso. Esse riso poderá ser o resultado do efeito com que o eu lírico trata os elementos do repertório feminino contemporâneo: se as mulheres da contemporaneidade da escritora Adília Lopes, leitoras a quem ela se dirige, lêem nas revistas femininas, por hipótese, dicas sobre tratamentos para o cabelo, Mariana será confrontada com essa máscara. E como ela preferia ser o retrato da sofredora, fará uma figura risível. Se, em vez de ágil e de prática, ela era redundante e estava sempre às voltas com o discurso amoroso, será apresentada pelo eu lírico no ridículo da sua repetição e do seu estilo. Não se trata, a nosso ver, de contestar as Cartas portuguesas, mas de trazê-las para o presente sem embaraços e sem reflexões profundas. A linguagem que outrora poderia ser usada por Mariana - partilhada por mulheres de muitas épocas, na realidade - também auxilia Adília a compor um universo feminino: o hipocorístico “Mimi”, a fórmula gasta “meu amor”, as expressões de contrariedade "que nojo" e "que raiva”, com que às vezes as mulheres pontuam o discurso estão em evidência. O coquetismo feminino tem sua graça, afinal, se for assimilado como coquetismo. E as soluções tão femininas, como o comer bombons durante momento de ansiedade, o falar da falta de dinheiro sem o imperativo masculino do peso da sobrevivência (“o dinheiro não traz o marquês de Chamilly / sobretudo quando é pouco”), o preferir estar acompanhada (mesmo que por uma lagartixa) etc, também são úteis para relativizar a importância de um mundo tão antigo como o barroco e de outro tão difícil de classificar, como o contemporâneo. Até o reconhecimento da sensualidade em Mariana se transforma em brincadeira, pois Mariana decide namorar um gigolô. No fundo, todo o drama se converteu em graça. 


\section{CONCLUSÃo}

As duas religiosas que estudamos ao longo desta investigação oferecem ao pesquisador desde sempre uma série de desafios, que começam na tentativa de encontrar modelos de escrita; se não é tarefa fácil verificar referências que foram indubitavelmente compartilhadas, esforçamo-nos por buscar, pelo menos, uma formação aproximada. Nesse percurso, pensamos ter descoberto que ambas tiveram conhecimento da obra de Santa Teresa, uma vez que têm em comum com ela, e uma com a outra, o tema da paixão: Sóror Mariana Alcoforado, talvez por força de uma experiência pessoal, centrou-se na paixão amorosa; Sor Juana, desejosa de conquistas intelectuais e de interlocução, centrou-se na paixão pelo conhecimento. O que nos contém, entretanto, é o fato de a paixão ser observada entre os temas de eleição de muitas escritoras. A constatação torna arriscado asseverar que Sóror Mariana e Sor Juana leram Santa Teresa, extraindo dessa fonte a predileção pelo tema da paixão, mas também acaba por reforçar o elo entre elas e muitas outras escritoras. Em outras palavras, podemos dizer que apontar Santa Teresa e o tema da paixão legitimam a causa desta tese. E a profundidade com que ambas mostraram a paixão, resgatando pelas transgressões e pelo domínio da escrita aquela emoção antes vista nos textos pautados pelo amor cortês, seduziram e seduzem os leitores; porque parece que se vive mais o projeto intelectual feminino estando à beira do empenho delas, da vida que elas emprestaram aos seus textos. Paixão, transgressão e o nome das escritoras subsistem nos poemas, subsistem nas cartas. 
Ambas igualmente podem ter absorvido ensinamentos dos textos de Quintiliano e de Luís de la Puente, como também podem ter lido Palafox. Com modelos em alguns pontos semelhantes produziram, no entanto, em medidas e com intenções distintas.

Nenhuma delas demonstrou especial apego aos modelos literários, ao que parece, ou melhor, não se mostraram restritas aos modelos; certamente receberam por via indireta influências de grandes nomes da literatura, o que no caso de Sor Juana, mais erudita, é uma certeza. As pinturas feitas a partir de uma idéia da aparência de Sóror Mariana não privilegiaram objetos pessoais, como os livros, para que outras épocas pudessem associar a ela ou depreender da personalidade de quem escreveu as Cartas portuguesas, para além de que as cinco cartas que a ela podem ser atribuídas não evidenciam nenhuma intertextualidade baseada em escritor ilustre. Já os retratos de Sor Juana feitos por Juan de Miranda e por Miguel Cabrera, por exemplo, focalizam tratados, grossos volumes das ciências, ma não livros de poesia. Essa construção, essa montagem que é da responsabilidade dos pintores não nos autoriza, no entanto, a excluir do repertório de Sor Juana os poetas de épocas anteriores à dela - os poetas contemporâneos de Sor Juana eram para ela, como pudemos ver algumas vezes, quase rivais, elas o conhecia e tentava superá-los. Paz, à p. 149 de Sor Juana Inés de la Cruz o las trampas de la fe, fez a seguinte afirmação, que a nós basta para tornar pacífica a questão das leituras de literatura de ficção: “Los poemas eróticos de sor Juana son ilustraciones de una metafísica, una estética y una retórica que vienen de la poesia provenzal y de Dante, son recogidas por Petrarca e inspiran a los poetas del Renacimiento y de la Edad Barroca”. 
Mais do que procurar pontos de contato na formação, podemos sublinhar o quanto as duas escritoras nos fizeram refletir sobre a questão da capacidade feminina em associação com as possibilidades de assimilação masculina no mundo barroco. Pode ser que tenham ambas estado, com consciência ou sem, diante do drama da atividade e do protagonismo feminino: ser ativa, no contexto em que Sóror Mariana e Sor Juana viveram, seria mais ou menos fértil do que ser passiva? Não se trata simplesmente de verificar a produtividade. Sor Juana tem, como já expusemos, uma produção literária muitíssimo superior à produção atribuída a Sóror Mariana; terá, contudo, vivido plenamente o ofício que escolheu por causa da atividade intensa ou a despeito dela? Não havendo fórmula mais ou menos adequada para isso, pareceu-nos que uma escritora tão capaz quanto prudente teria mais oportunidades. Porque a oportunidade, se não deriva sempre da capacidade, ao menos não é afastada, muito menos afastada drasticamente, se o excesso de energia se interpõe na trajetória da escritora. A transgressão de Sóror Mariana e de Sor Juana tem valor histórico inestimável, denuncia a tenacidade feminina, mas levada a cabo como foi pode ser sinônimo de interrupção e de bloqueio do que poderia vir a ser uma tradição.

As mesmas perguntas podem ser feitas por causa da opção feminina pela solidão. Ter independência e estar abrigada das atribulações que interrompem o trabalho intelectual traz benefícios, mas pode também ser acompanhada de algum tipo de aliança entre mulheres. Insistimos, portanto, no valor da cumplicidade, sobretudo se ela for superior ao controle exercido pelos homens. Na época em que Sóror Mariana e Sor Juana viveram, esse controle era sem dúvida insistente e eficaz e, por isso mesmo, superou as possibilidades 
advindas da cumplicidade feminina. Sor Juana escrevia para outras mulheres, dedicava poemas a outras mulheres, teve a ajuda de uma delas para a publicação de suas obras, mas quando se tratava de ultrapassar um limite indesejável do ponto de vista masculino, o controle foi mais determinante do que a confiança que a cumplicidade pode ter investido na religiosa.

Com relação à paixão, propomos ainda uma última reflexão, só que desvinculada da observação das leituras formativas. Pareceu-nos que Sóror Mariana e Sor Juana foram absorvidas pela paixão. Se escritoras de outra época tiveram uma relação com a paixão mais estável e mais catártica, Sóror Mariana se desviou para a figura de louca e Sor Juana viveu a paixão ao lado do narcisismo e no seio de um regime tão ameaçador, que se deixou absorver por ela também. A aposta retórica na figura da louca, por parte de Sóror Mariana, pode ter estado subjacente na repetição; a renúncia de Sor Juana pode ter-se espelhado na recusa de algum grau de insucesso ou de algum obstáculo. Mais acostumada à fama do que ao anonimato, Sor Juana sobressaiu numa relação com a Igreja, quando o mais cauteloso seria que tivesse dominado alguma vaidade? A linha de raciocínio nos leva de volta à supremacia dos modelos masculinos e à necessidade de brilhantismo como princípio masculino. O que será, afinal, o conhecimento? Sor Juana teria conhecido menos, caso tivesse arriscado menos? Ela arriscava, ao mesmo tempo, o conhecer e o publicar, em nome do publicar. Por outro lado, se respeitamos o que foi a vontade dela, temos de admitir que conhecer significava saber e compartilhar em seguida. E como compartilhar naquele mundo competitivo, sendo uma mulher de talento impressionante? Ser protagonista, no contexto barroco, tinha quase que um só número para as mulheres, isto é, era o mesmo que representar e representar o 
papel da subjugada, ou pelo apagamento ou pela queda súbita. Ao longo desta tese lidamos com várias evidências empíricas da força do sistema traçado e regulado pelos homens, mesmo que nele uma mulher mais vaidosa e bem preparada forçasse a entrada. 
AnEXos

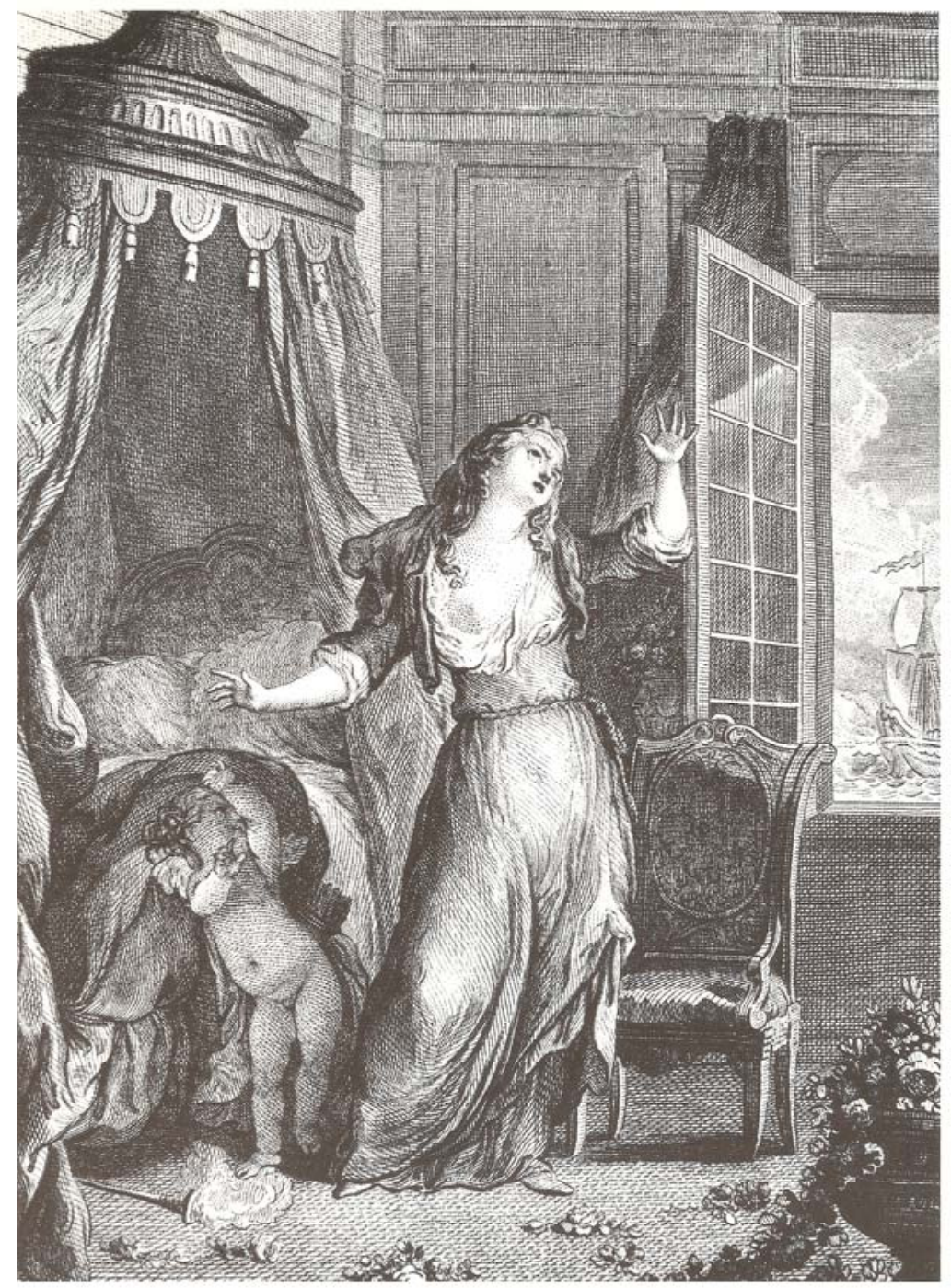

Fig. 3 - Sóror Mariana, por Massard (1771) 


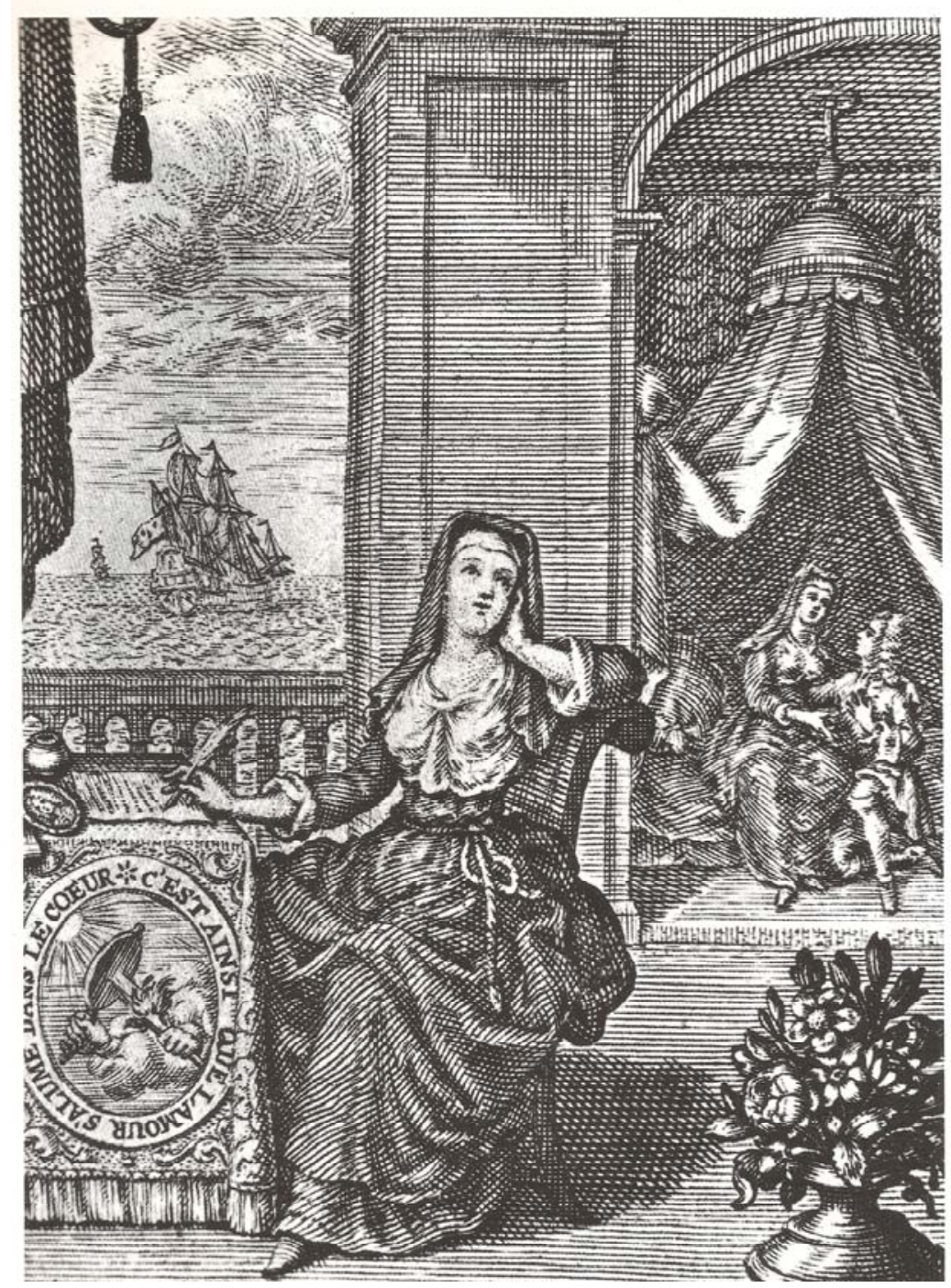

Fig. 4 - Sóror Mariana, por Coster (1716) 


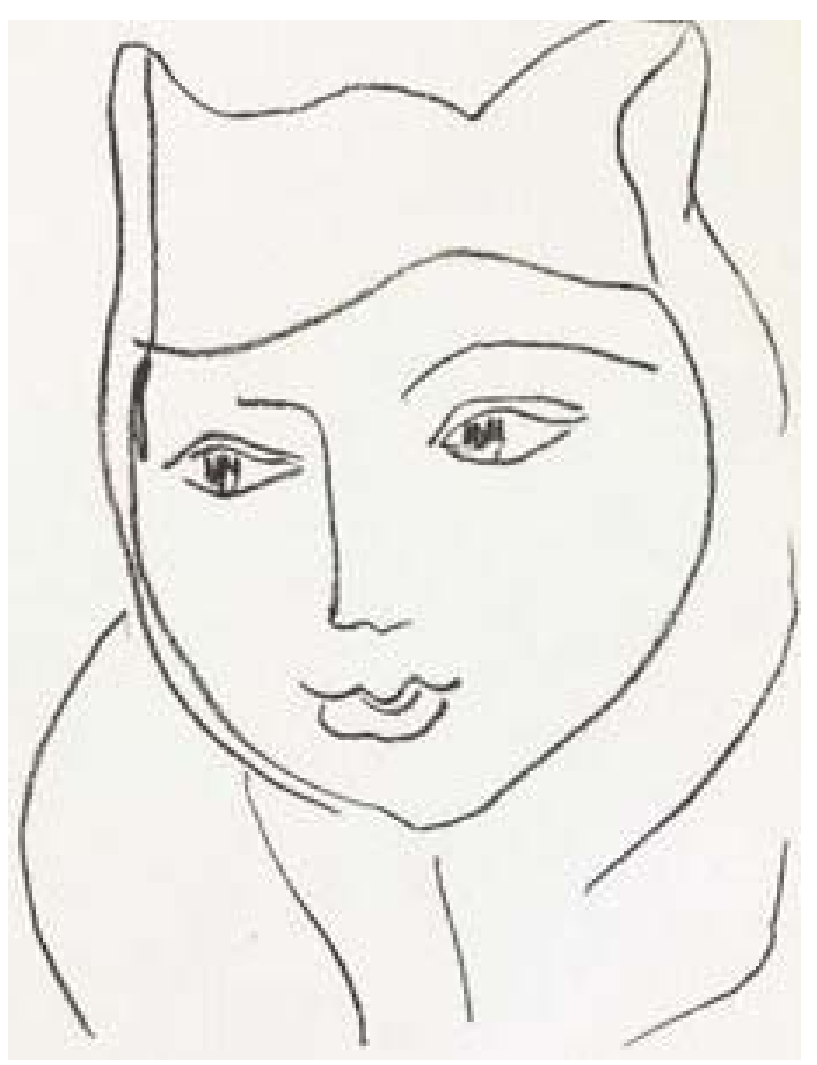

Fig. 5 - Sóror Mariana, por Matisse 


\section{BIBLIOGRAFIA}

ABRANCHES, Graça, “A varanda de onde se avista Mértola”, História e antologia da literatura portuguesa - século XVII, nº 32, pp. 26-28.

ALATORRE, António. Enigmas ofrecidos a la Casa del Placer. Sor Juana Inés de la Cruz. México, El Colegio de México, 1994.

ALBORCH, Carmen. Mulheres contra mulheres. Rivalidades e cumplicidades. Lisboa, Editorial Presença, 2004.

ALCOFORADO, Mariana. Cartas portuguesas. Tradução de Nuno de Figueiredo. Lisboa, Publicações Europa-América, 1974.

Cartas portuguesas. Tradução de Eugénio de Andrade. Lisboa, Assírio \& Alvim, 1993.

ALMADA NEGREIROS. Manifesto Anti-Dantas e por extenso por José de Almada-Negreiros, poeta d'Orpheu futurista e tudo. Porto, Presença, [19001950].

ASSIS, Santa Clara de. Cartas a Santa Inês de Praga. Tradução de Fr. José António Correia Pereira e Ir. Maria Gabriela da Virgem. Braga, Editorial Franciscana, 1993.

ÁVILA, Affonso. O lúdico e as projeções do mundo barroco I. Uma linguagem a dos cortes. Uma consciência a dos luces. São Paulo, Perspectiva, 1994. Barroco. Teoria e análise. São Paulo, Perspectiva, 1997.

BARBOSA, Jerónimo Soares (org.). Instituições oratórias de M. Fábio Quintiliano escolhidas dos seus XII livros, traduzidas em linguagem e ilustradas com notas críticas, históricas e retóricas para uso dos que aprendem. Ajuntam- 
se no fim as peças originais de Eloquência, citadas por Quintiliano no corpo destas Instituições. Coimbra, Imprensa da Universidade, 1836.

BARRENO, Maria Isabel, HORTA, Maria Teresa e COSTA, Maria Velho da. Novas cartas portuguesas. Lisboa, Moraes Editores, 1980.

BARRETO, Teresa Cristófani. Sór Juana Inés de la Cruz. Letras sobre o espelho. São Paulo, Iluminuras, 1989.

BARTHES, Roland. Fragmentos de um discurso amoroso. Tradução de Isabel Pascoal. Lisboa, Edições 70, 1977.

BENJAMIN, Walter. Rua de sentido único e Infância em Berlim por volta de 1900. Traduções de Isabel de Almeida e Sousa e de Cláudia de Miranda Rodrigues. Lisboa, Relógio D’Água, 1992.

BLOOM, Harold. O cânone ocidental: os livros e a escola do tempo. Tradução de Marcos Santarrita. Rio de Janeiro, Objetiva, 2001.

BOLOGNE, Jean-Claude. História do pudor. Tradução de Telma da Costa. Lisboa, Teorema, 1986.

BOSSE, Monika, POTTHAST, Barbara e STOLL, André. La creatividad femenina en el mundo barroco hispánico: María de Zayas, Isabel Rebeca Correa, Sor Juana Inés de la Cruz. v. II. Kassel, Edition Reichenberger, 1999.

BRAGA, Teófilo. Estudos da Idade Média. Porto, Livraria Internacional, 1870.

BRONTË, Charlotte. Jane Eyre. Tradução de Sodré Viana. Rio de Janeiro, Ediouro, s/d.

BUESCU, Ana Isabel. Imagens do príncipe. Discurso normativo e representação (1525-49). Edições Cosmos. 
BUTLER, Judith. Bodies that matter: on the discursive limits of "sex". New York, Routledge, 1993.

, "Fundamentos contingentes: o feminismo e a questão do 'pósmodernismo'", cadernos pagu, no 11, 1998, pp. 11-42.

, "O parentesco é sempre tido como heterossexual?", cadernos pagu, $\mathrm{n}^{0} 21,2003$, pp. 219-260.

Problemas de gênero. Feminismo e subversão da identidade.

Tradução de Renato Aguiar. Rio de Janeiro, Civilização Brasileira, 2003.

BUXÓ, José Pascual. Las figuraciones del sentido. Ensayos de poética semiológica. México, Fondo de cultura económica, 1997.

CAMPOS, Haroldo de. O seqüestro do barroco na formação da literatura brasileira: o caso Gregório de Mattos. Salvador, Fundação Casa de Jorge Amado, 1989.

CANDIDO, Antonio. Formação da literatura brasileira (momentos decisivos). Belo Horizonte / Rio de Janeiro, Editora Itatiaia, 1959.

CARBONELL, Neus y TORRAS, Meri (compilación de textos y bibliografía). Feminismos literarios. Madrid, Arco/Libros, 1999.

CARVALHO, Joaquim Montezuma de. Sor Juana Inés de la Cruz e o Padre António Vieira ou a disputa sobre as finezas de Jesus Cristo. Lisboa, Vega, 1998.

CARVALHO, Lúcia Helena de O. V., “A ponta farpada ou o lugar marcado da mulher no discurso da tradição”. Anais do III Encontro Nacional da ANPOLL, 1988, pp. 25-32.

CHAGAS, Fr. António das. Cartas espirituais. Edição de Isabel Morujão. Porto, Campo das Letras, 2000. 
CHAVES, Castelo Branco. O Romance histórico no romantismo português. Instituto de Cultura Portuguesa, 1979.

CHIANCA, Ruy. Desventurado amor. Romance de Sóror Mariana. Lisboa, Livraria Clássica Editora, 1916.

COELHO, Jacinto do Prado. Dicionário de literatura. Porto, Mário Figueirinhas Editora, 1994.

CORDEIRO, Luciano. Sóror Mariana, a freira portuguesa. Lisboa, Livraria Ferin \& $C^{\mathrm{a}}, 1890$.

CORREIA, João da Silva. A linguagem da mulher. Lisboa, Academia das Ciências de Lisboa, 1935.

COSTA, Horácio. Mar abierto. Ensayos sobre literatura brasileña, portuguesa e hispanoamericana. México, Fondo de Cultura Económica, 2000. "Sobre os enigmas de Soror Juana Inés de la Cruz encontrados em Lisboa, ou de como o México, pouco a pouco, mas inexoravelmente, aproxima-se de Portugal, e vice-versa", Via Atlântica, nº 4, 2000, pp. 148-156.

COSTA E SILVA. Soror Mariana Alcoforado. Lisboa, Typographia Adolpho de Mendonça, 1912.

COUTINHO, Afrânio. A literatura no Brasil. v. I, tomo 1. Rio de Janeiro, Editorial Sul Americana, 1955.

COUTINHO, B. Xavier. Um escritor a menos na literatura portuguesa: Soror Mariana Alcoforado. Lisboa, 1980.

CRUZ, Sor Juana Inés de la. Obras completas de Sor Juana Inés de la Cruz. Edición, prólogo y notas de Alfonso Méndez Plancarte. I e IV. México, Fondo de Cultura Nacional, 2004. 
D’ALEMBERT e DIDEROT, Denis. Encyclopédie. 1755-1765. http://quod.lib.umich.edu/d/did/, consultado em 19.01.2010.

DESENGANO, Amador do. Espelho critico, no qual claramente se vem alguns defeitos das Mulheres, fabricado na loja da verdade pelo Irmão Amador do Desengano, 'que póde servir de estimulo para a reforma dos mesmos defeitos'. Lisboa, Off. de António Vicente da Silva, 1761.

DIAS, Baltasar. Malicia das Mulheres, [...] porque nella se tratão muitas sentenças, authoridades àcerca da malicia, que ha em algumas dellas, [...]. Lisboa Occidental, Off. de António Alvares, 1640.

FEIJOO MONTENEGRO, Fray Benito. "Defensa de las mujeres”, 1736. http://www.filosofia.org/bjf/bjft116.htm, consultado em 13.09.2009.

FERNANDES, Maria de Lurdes Correia, “Recordar os 'santos-vivos': leituras e práticas devotas nas primeiras décadas do século XVII português”, Via Spiritus, $\mathrm{n}^{\circ}$ 1, 1994, pp. 133-155.

“Viúvas ideais, viúvas reais. Modelos comportamentais e solidão feminina (séculos XVI-XVII)”, Faces de Eva, nº 1-2, 1999, pp. 51-86.

FERREIRA, Godofredo. Soror Mariana Alcoforado morreu há 200 anos. Tipografia Aguedense Águida, 1923.

FIGUEIREDO, Fidelino de. Literatura portuguesa. Desenvolvimento histórico das origens à actualidade. Rio de Janeiro, Editora A Noite, 1941.

FOUCAULT, Michel. História da sexualidade. A vontade de saber. v. 1. Tradução de Maria Thereza da Costa Albuquerque e J. A. Guilhon Albuquerque. São Paulo, Graal, 2005. O que é um autor? Tradução de António Fernando Cascais e Edmundo Cordeiro. Vega, 1992. 
GALVÃO, Walnice Nogueira e GOTLIB, Nádia Battella (orgs.). Prezado senhor, prezada senhora: estudo sobre cartas. São Paulo, Companhia das Letras, 2000.

GALVÃO, Walnice Nogueira. "Mulheres e poetas", D. O. Leitura, Ano 23, nº 1, 2005, pp. 23-33.

GILBERT, Sandra M. e GUBAR, Susan. The madwoman in the attic. The woman writer and the nineteenth-century literary imagination. Yale, 2000.

GOMES, A. Sousa. Madre Mariana Alcoforado. Sua graça e seu amor. Lisboa, s/n, 1964.

GONÇALVES, Margareth de Almeida. Império da fé. Andarilhas da alma na era barroca. Rio de Janeiro, Rocco, 2005.

GOTLIB, Nádia Battella, “A mulher na literatura - uma representação”. Anais do III Encontro Nacional da ANPOLL, 1988, pp. 15-32.

GRAÇA, Paula da. Bondade das Mulheres vendicada e malicia dos Homens manifesta. Papel métrico, e apologetico, em que se defende a femenina innocencia, contra outro em que injustamente se arguê a sua maldade, com o titulo de Malicia das Mulheres / por Paula da Graça. Lisboa, Off. de Bernardo da Costa de Carvalho, 1715.

HANSEN, João Adolfo. A sátira e o engenho. São Paulo, Companhia das Letras, 1989.

HATHERLY, Ana. A casa das musas. Uma releitura crítica da tradição. Lisboa, Editorial Estampa, 1995.

Lampadário de cristal de Frei Jerónimo Baía. Lisboa, Editorial

Comunicação, 1992. 
Poesia incurável. Aspectos da Sensibilidade Barroca. Editorial

Estampa, 2003.

HATZFELD, Helmut. Estudos sobre o Barroco. Tradução de Célia Berrettini. São Paulo, Perspectiva, 2002.

HOLANDA, Heloísa Buarque de (org.). Tendências e impasses. O feminismo como crítica da cultura. Rio de Janeiro, Rocco, 1994.

JESUS, Gertrudes Margarida de. Primeira carta apologetica, em favor e defensa das mulheres, escrita por Dona Gertrudes Margarida de Jesus, ao Irmão Amador do Dezengano, 'com a qual destroe toda a fabrica do seu Espelho Critico’. Lisboa, Off. de Francisco Borges de Sousa, 1761.

JESUS, Gertrudes Margarida de. Segunda carta Apologetica, em favor, e defensa das mulheres, escrita por Dona Gertrudes Margarida de Jesus, ao Irmão Amador do Dezengano, 'com a qual destroe toda a fabrica do seu Espelho Critico. E se responde ao terceiro defeito, que nelle contemplou'. Lisboa, Off. de Francisco Borges de Sousa, 1761.

KAFKA, Franz. Três cartas a Milena Jesenská. [Verão de 1920]. Tradução e apresentação de Álvaro Gonçalves. Lisboa, Assírio \& Alvim, 2003.

KLOBUCKA, Anna. Mariana Alcoforado. Formação de um mito cultural. Tradução de Manuela Rocha. Lisboa, Imprensa Nacional - Casa da Moeda, 2006.

, “Sobre a hipótese de uma herstory da literatura portuguesa”, Veredas, $\mathrm{n}^{\mathrm{o}}$ 10, 2008, pp. 13-25.

, “Sóror Mariana Alcoforado. Uma ficção literária”, História e antologia da literatura portuguesa - século XVII, n ${ }^{0}$ 32, pp. 28-31. 
KOFMAN, Sarah, “Os fins falocráticos de Rousseau”, Revista de Comunicação e Linguagens, $\mathrm{n}^{\circ}$ 5, 1987, pp. 35-44.

LAKOFF, Robin. Language and woman's place. New York, Harper Colophon Books, 1975.

LISPECTOR, Clarice. Correio feminino. Organização de Aparecida Maria Nunes. Rio de Janeiro, Rocco, 2006.

LOPES, Adília. Obra. Lisboa, Mariposa Azul, 2000.

MACHADO, Álvaro Manuel. Dicionário de literatura portuguesa. Lisboa, Editorial Presença, 1996.

MAIA, Rita Maria de Abreu, "O amor e a pena feminina. Escrita feminina e insurreição amorosa”. Universidade Federal do Rio de Janeiro, 2001.

MARINHO, Maria de Fátima. O romance histórico em Portugal. Porto, Campo das Letras, 1999.

MELO, D. Francisco Manuel de. Carta de guia de casados. Edição de Maria de Lurdes Correia Fernandes. Porto, Campo das Letras, 2003.

MIRANDA, Ana. Que seja em segredo. Rio de Janeiro, Dantes, 1998.

MORUJÃO, Isabel, "Livros e leituras na clausura feminina de setecentos”, Revista Línguas e Literaturas, Porto, nº XIX, 2002, pp. 111-170. , "Poesia e santidade, alguns contributos para uma percepção do conceito de santidade, a partir de duas biografias devotas de religiosas do século XVII português”, Via Spiritus, nº 3, 1996, pp. 235-261.

NOGUEIRA, Manuela e AZEVEDO, Maria da Conceição (orgs.), Cartas de Amor de Ofélia a Fernando Pessoa. Lisboa, Assírio \& Alvim, 1996. 
NUNES, Benedito. O drama da linguagem. Uma leitura de Clarice Lispector. São Paulo, Ática, 1995.

NUNES, Maria Teresa Arsénio, “Sinceridade e epistolografia. Como o verde nas folhas”, Colóquio /Letras, n 140/141, 1996, pp. 61-70.

ORTEGA Y GASSET, José. Estudos sobre o amor. Tradução de Elsa Castro Neves. Lisboa, Relógio D’Água, 2002.

PALMA-FERREIRA, João. Antónia Margarida de Castelo Branco. Autobiografia. Lisboa, Imprensa Nacional- Casa da Moeda, 1984.

PARADINHA, Maribel. As cartas de Soror Mariana Alcoforado. Manipulação e identidade nacional. Casal de Cambra, Caleidoscópio, 2004.

PAZ, Octavio. A dupla chama. Amor e erotismo. Tradução de Wladyr Dupont. São Paulo, Siciliano, 1994.

Sor Juana Inés de la Cruz o las trampas de la fe. México, Fondo de Cultura Económica, 2003.

PRESTAGE, Edgar. D. Francisco Manuel de Melo. Esboço biográfico. Lisboa, Fenda, 1996.

QUINTILIANO, M. Fábio. Instituições oratórias. São Paulo, Edições Cultura, 1944.

RILKE, Rainer Maria. As elegias de Duíno e Sonetos a Orfeu. Tradução de Paulo Quintela. Porto, Inova, 1968.

SARAMAGO, Alfredo. Convento de Soror Mariana Alcoforado, Real Mosteiro de Nossa Senhora da Conceição: ensaio histórico. Sintra, Colares Editora, 1994. SARAMAGO, José. Viagem a Portugal. Lisboa, Editorial Caminho, 1995. 
SARDUY, Severo. Barroco. Tradução de Maria de Lurdes Júdice e José Manuel de Vasconcelos. Lisboa, Vega, 1989.

SCHAMA, Simon. O poder da Arte. BBC, 2007.

SENA, Jorge de. Estudos de literatura portuguesa - II. Lisboa, Edições 70, 1986.

SILVA, Innocencio Francisco da e BRITO ARANHA. Diccionario bibliographico portuguez. Lisboa, Comissão Nacional para as Comemorações dos Descobrimentos Portugueses, 2001.

SPINA, Segismundo e CROLL, Morris W. Introdução ao Maneirismo e à prosa barroca. São Paulo, Ática, 1990.

UREÑA, Camila Henríquez. Obras y apuntes. Ciudad de la Habana, Editorial Universitaria, 2006.

VASCONCELOS, Mário Cesariny de. Horta de literatura de cordel: o continente submerso, o grande teatro do mundo, os sobreviventes do dilúvio, monstros nacionais, monstros estrangeiros. Lisboa, Assírio \& Alvim, 1983.

VAZ, Katherine. Mariana. Tradução de José Luís Luna. Porto, Edições Asa, 1999.

VAZ, Salema. Soror Amor. Lisboa, Imprensa Lucas \& Ca, 1929.

VENTURA, Maria da Graça M. (coord.). O barroco e o mundo ibero atlântico. Lisboa, Edições Colibri, 1998.

VICENTE, Ana. Mulheres em discurso. Lisboa, Imprensa Nacional - Casa da Moeda, 1987.

VIEIRA, Antônio. As lágrimas de Heráclito. São Paulo, Editora 34, 2001. Cartas do Brasil. Organização de João Adolfo Hansen. São

Paulo, Hedra, 2003. 
VILLARI, Rosario (dir.). O homem barroco. Tradução de Maria Jorge Vilar de Figueiredo. Lisboa, Editorial Presença, 1995.

WOOLF, Virginia. Um quarto que seja seu. Tradução de Maria Emília Ferros Moura. Lisboa, Vega, 1996.

http://www.museuregionaldebeja.net/sorormarianaalcoforado.htm, consultado em 14.07.2007.

http://www.renatojanine.pro.br/LEstrangeira/stendhal.html, consultado em 14.07.2007.

http://www.vidaslusofonas.pt/almada_negreiros.htm, consultado em 14.07.2007. 